\title{
Site U1349'
}

\author{
Expedition 324 Scientists $^{2}$
}

\section{Chapter contents}

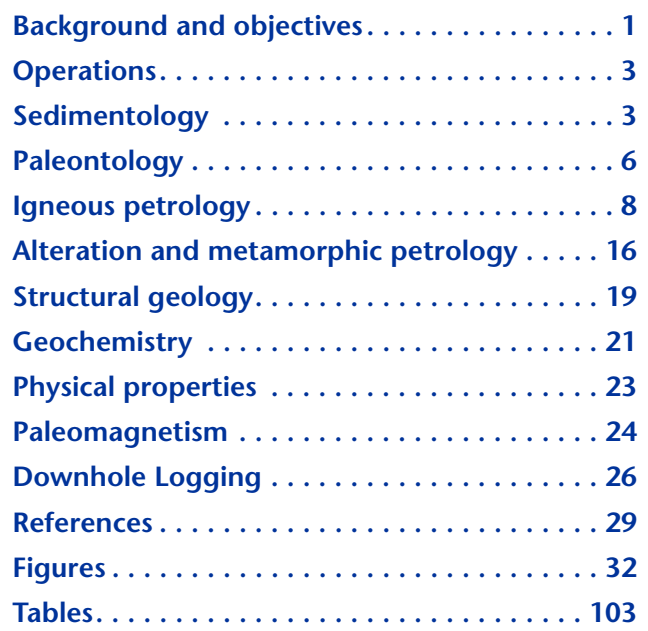

'Expedition 324 Scientists, 2010. Site U1349. In Sager, W.W., Sano, T., Geldmacher, J., and the Expedition 324 Scientists, Proc. IODP, 324: Tokyo (Integrated Ocean Drilling Program Management International, Inc.).

doi:10.2204/iodp.proc.324.106.2010

'Expedition 324 Scientists' addresses.

\section{Background and objectives}

\section{Background}

Integrated Ocean Drilling Program Site U1349 (proposed Site SRCH-5) on Ori Massif was the fourth site completed during Expedition 324. This site is near the center of a north-south transect across Shatsky Rise and was intended to sample the summit of the large Ori Massif volcanic edifice (Fig. F1). Only one hole, U1349A, was cored at the site. According to the initial expedition plan, Site U1349 was to be the second deepest penetration site to be drilled, with a target of $\sim 200 \mathrm{~m}$ into igneous basement. As with all Expedition 324 sites, the penetration rate of drilling was slower than expected, and this goal was not reached. Unlike some other sites of this expedition, Hole U1349A was terminated because the material being recovered did not justify further drilling. Approximately $86 \mathrm{~m}$ of basement rocks was recovered, but alteration was severe and did not appear to improve with depth. Thus, the science party decided to cease drilling and to move on to Site U1350. Despite the alteration, the rocks recovered from Site U1349 tell a story of eruption of primitive lavas near or above sea level, erosion, and extensive and variable alteration with burial and submergence.

Ori Massif is the second largest volcanic construct within Shatsky Rise, with a volume of $\sim 0.7 \times 10^{6} \mathrm{~km}^{3}$ (Sager et al., 1999). Similar to Tamu Massif, Ori Massif may have formed over a geologically short period of time ( $<1$ m.y.) with a high effusion rate, but the actual age and duration are unknown. Because Ori Massif is separated from Tamu Massif by a narrow, rectangular, faulted basin ("Helios Basin;" see F2 in the "Expedition 324 summary" chapter), there has been speculation that Ori and Tamu massifs formed together and later rifted (Sager et al., 1999; Nakanishi et al., 1999). In the context of the plume head hypothesis, Ori Massif appears to represent the eruptions during a transition in volume from plume head (Tamu Massif) to plume tail (Papanin Ridge).

Magnetic lineations surrounding Ori Massif imply it formed on lithosphere of earliest Cretaceous age. Anomaly M16 brackets the southeast flank, whereas Anomaly M14 crosses the northwest flank (Nakanishi et al., 1999; see F3 in the "Expedition 324 summary" chapter). According to the geomagnetic polarity timescale (GPTS; Ogg et al., 2008), the age of the lithosphere at Ori Massif is 142-140 Ma, which may also be the age for Ori Massif if it formed nearly synchronously with the lithosphere, as implied by 
compensation (Sandwell and McKenzie, 1989). The northeast and southwest flanks of Ori Massif appear to be bounded by fracture zones (Nakanishi et al., 1999), and this bracketing by spreading ridges and fracture zones, which are orthogonal, may be the reason that the massif appears subcircular or nearly square in plan view (Sager et al., 1999).

Like Tamu Massif, Ori Massif has the appearance of a large central volcano with low flank slopes (Sager et al., 1999). Too few bathymetry data exist to say which flanks of this edifice are smooth and which are faulted, although the shape of the southern margin implies rifting. As with other Shatsky Rise massifs, the rise top is covered with pelagic sediment that reaches maximum thicknesses of $600-700 \mathrm{~m}$ on existing seismic profiles (Figs. F2, F3) (Sager et al., 1999; Klaus and Sager, 2002). Like Tamu Massif, Ori Massif has volcanic summit ridges, although all are buried, or mostly so, and therefore are not as prominent as the large ridge (Toronto Ridge; Sager et al., 1999) atop Tamu Massif. The origin of these ridges is not known; however, they appear to be volcanic constructs and not fault-bounded ridges (i.e., horsts). Site U1349 was drilled into one such ridge, a flattopped ridge located near the middle of the Ori Massif summit (see fig. 10 in Sager et al., 1999, for a seismic line crossing near the site). It was thought that because this ridge has a flat top and is at the tallest point on the volcano, it was probably eroded flat by wave action at sea level. Thus, evidence for subaerial exposure was an expected result from Site U1349 drilling.

\section{Scientific objectives}

Sampling the summit of Ori Massif was an important objective because this volcano is a major edifice within Shatsky Rise. Furthermore, Site U1349 is at the center of a transect of sites along the axis of Shatsky Rise expected to yield age and geochemical trends within the plateau. As with most Expedition 324 sites, the operational goal for the site was to drill through the sediment overburden, core the oldest sediment overlying igneous basement, and core as deeply into the igneous formation as possible in the time allowed.

Scientific objectives of all Expedition 324 sites are similar (for more details and rationale, see the "Expedition 324 summary" chapter). Coring of igneous rock was planned to determine the age of igneous basement so that the age progression and duration of volcanism at Shatsky Rise can be constrained. A critical objective at Site U1349, and indeed at all Expedition 324 sites, was to core enough igneous rock of suitable freshness and composition to allow at least one reliable radiometric date to be established. Igneous rocks are critical to geochemical and isotopic studies, the goals of which are to establish the elemental compositions of the rocks, variations in compositions, and the isotopic characteristics. Such data are crucial for determining the source of magma, inferring its temperature and depth of melting and crystallization, and deducing the degree of partial melting, as well as tracking its evolution with time. Operationally, this meant that at Site U1349 the goal was to core a representative suite of igneous units that were fresh enough to provide reliable geochemical and isotopic measurements.

Expedition 324 also sought to constrain the evolution of Shatsky Rise by collecting samples for a host of nongeochemical studies that focused on varied aspects of rise geology. Physical volcanologists, structural geologists, and logging geophysicists will use cores and logs to infer the eruption style, igneous products, and physical structure of Shatsky Rise. Given its size and inferred eruption rate, Ori Massif is likely to be an example of an unusual volcanic construct, the development which is poorly understood. Shatsky Rise core samples will also be used to study the submarine alteration of igneous rock and its effect on other analyses. Considering the altered nature of the rocks recovered from this site, alteration studies will play a critical role in better understanding and using other data sets. Studies of sediments overlying igneous basement are planned to better understand the paleontological age of Shatsky Rise sediments and the processes and rates of Cretaceous sedimentation atop the rise volcanoes. It was hoped that shallow-water sediments would be cored at Site U1349, but sediment recovery was poor. Nevertheless, sedimentologists will carefully examine the sparse sediments that were recovered. Sediment types and paleontological environment data will hopefully indicate the paleodepths of sediment deposition, which is important for understanding the eruption and subsidence history of the volcanic edifices. Paleomagnetic study of the samples recovered during Expedition 324 seeks to determine the magnetic polarity of basement for comparison with surrounding magnetic lineations and the GPTS, as well as the paleolatitude of the rise and its plate tectonic drift. Physical properties of Shatsky Rise core samples will be measured to better understand the nature of the rocks that make up the rise and to constrain fundamental physical properties that affect geophysical imaging and remote sensing. Because of the extensive alteration of Site U1349 rocks, physical property measurements will be important for determining changes in rock properties with alteration. 


\section{Operations}

Times in this chapter are given in local ship time. During transit to Site U1346, shipboard clocks were advanced $1 \mathrm{~h}$, resetting local ship time to Sydney Standard Time (Universal Time Coordinated $+10 \mathrm{~h}$ ). No further adjustments to the clock were made during the expedition.

The $112 \mathrm{nmi}$ transit from Site U1348 to Site U1349 required $12.2 \mathrm{~h}$ at an average speed of $9.2 \mathrm{kt}$. By 1245 h on 7 October 2009, the vessel was positioned on the new drill site.

The drill string was routinely deployed, and after the driller tagged seafloor at $3138.0 \mathrm{~m}$ drilling depth below rig floor (DRF) (3127.0 meters below sea level [mbsl]) (Table T1) or $\sim 5 \mathrm{~m}$ deeper than the corrected precision depth recorder depth, Hole U1349A was spudded with the rotary core barrel (RCB) system at $0600 \mathrm{~h}$ on 8 October. The hole was drilled with a wash barrel to $116 \mathrm{~m}$ drilling depth below seafloor (DSF), where coring was initiated. The sediment portion of the hole was cored with the usual low average recovery (23\%) because of the prevalence of soft sediments and chert to $165.1 \mathrm{~m}$ DSF, where basement was encountered. Coring in the hole continued into basement without incident to $250.4 \mathrm{~m}$ DSF (85.3 m into basement) by $1430 \mathrm{~h}$ on 11 October, when coring in the hole was terminated early (see Fig. F4 for an overview). The decision to cut short coring at this site was made during a science meeting held earlier in the day. Hole U1349A was cored with an overall average recovery of $49.0 \%$. The basement portion of the hole was cored at an average rate of penetration of $1.8 \mathrm{~m} / \mathrm{h}$ and with an average recovery of $67.4 \%$.

The hole was prepared for logging with a $50 \mathrm{bbl} \mathrm{mud}$ flush followed by a round trip of the drill string from 250 to $86 \mathrm{~m}$ DSF. After an additional $50 \mathrm{bbl} \mathrm{mud}$ treatment, the bit was released at the bottom of the hole with the rotary shifting tool on the coring line. Prior to tripping the drill string to the logging depth of $119.3 \mathrm{~m}$ DSF, the hole was displaced with $56 \mathrm{bbl}$ of $10.5 \mathrm{ppg}$ heavy mud. The first log of Hole U1349A was made with the triple combination (triple combo) tool string, which was deployed at $2140 \mathrm{~h}$ on 11 October and retrieved at $0240 \mathrm{~h}$ the next morning. The second $\log$ was conducted with the Formation MicroScanner (FMS) tool string, which was deployed at $0355 \mathrm{~h}$ and recovered at $0930 \mathrm{~h}$. The hole was found to be good condition except for one tight spot just below the end of the pipe, and both the triple combo and FMS runs retrieved excellent data.

After the logging equipment was secured, the drill string was pulled out of the hole to $2880 \mathrm{~m} \mathrm{DRF}$, where the pipe trip was suspended for $1.5 \mathrm{~h}$ to conduct a routine slip and cut of $115 \mathrm{ft}$ of drilling line.
Once the drill string and beacon were recovered and the drilling equipment secured, the vessel departed for the next site at $1930 \mathrm{~h}$ on 12 October.

\section{Sedimentology}

One hole was drilled at Site U1349 on the summit of Ori Massif (water depth $=3127 \mathrm{mbsl}$ ). Sedimentary recovery reached $20 \%$, with $10.06 \mathrm{~m}$ of sediment recovered from Cores 324-U1347A-1W through 7R over a stratigraphic interval of $49 \mathrm{~m}$. Cores $1 \mathrm{~W}$ through $4 \mathrm{R}$ are predominately red chert with occasional ooze and porcellanite. Below Core $4 \mathrm{R}$ is a friable sand-silt-claystone sequence that also contains granules of highly weathered volcanic material. This section is so disturbed by drilling that further interpretation of the rock is difficult. Most of Cores $5 \mathrm{R}$ and $6 \mathrm{R}$ contain greenish gray volcaniclastic sandstones and lapillistones, likely deposited by turbiditic flows. A thin yellowish red clay-rich horizon in Section 324-U1349A-6R-CC is interpreted as a paleosol. Basement was reached in Core 7R at 165.1 meters below seafloor (mbsf), where highly vesicular oxidized basaltic flows were first encountered. Downhole, several other thin sedimentary layers are interbedded between basaltic lava sections. The most significant of these is an oolitic limestone in Section 324-U1349A-9R-1 at 173.7 mbsf, which downhole logging data suggest may be stratigraphically as thick as $6 \mathrm{~m}$.

\section{Unit descriptions}

The stratigraphy at Site U1349, including basaltic basement divisions and sedimentary interbeds, is shown in Figure F5.

- Unit I: red cherts with calcareous porcellanite coatings and pinkish ooze (116.0-135.3 mbsf).

- Unit II: sand-silt-claystone and sandstone with volcaniclastics (135.3-144.9 mbsf).

- Unit III: volcaniclastic sandstones, breccia, and conglomerate (144.9-165.1 mbsf); divided into two subunits:

- Subunit IIIa: volcaniclastic sandstones and volcaniclastic breccia (144.9-156.1 mbsf).

- Subunit IIIb: yellowish red clay-rich layer (paleosol?) (156.1-156.3 mbsf) and a brownish polymictic volcaniclastic conglomerate (156.3$165.1 \mathrm{mbsf})$.

- Unit IV: vesicular basaltic lava flows with occasional calcareous sedimentary interbeds (Subunits IVa, IVc, and IVd).

- Subunit IVb: oolitic limestone, with a large biogenic component and some volcaniclastics (173.7-173.8 mbsf) occurring as a sedimentary 
interbed between vesicular reddish brown basalt (see "Igneous petrology").

- Unit V: basaltic flow breccia; autobrecciated basalt and basaltic lava pods (see "Igneous petrology").

\section{Unit I}

Interval: 324-U1349A-1W through 4R

Depth: 116.0-135.3 mbsf

Red cherts are the dominant lithology of Unit I, which spans Sections 324-U1349A-1W-1 through 4R-1; however, one dark brown chert nodule was recovered at interval 324-U1349-4R-1, 4-6 cm. Several of the red cherts have porcellanite edges, which are partially silicified and contain numerous foraminifers. The foraminifers are closely packed and extend as far as $1.5 \mathrm{~cm}$ from the edge of the nodule toward the red chert center. Other chert pieces have thin (1$2 \mathrm{~mm}$ ) pale pinkish white porcellanite coatings. Radiolarian fossil "ghosts" are present but rare. Core 324-U1349A-2R contains $3 \mathrm{~cm}$ of pale pink nannofossil ooze with abundant planktonic and benthic foraminifers (see "Paleontology"). Some well-preserved fish debris is also present in this interval. No other soft sediments were recovered in this unit. Several red chert pieces were recovered in other units (Fig. F5); however, they are unlikely to be in situ and we regard them as "fall-in," as they are likely to have fallen from the borehole wall and were cored out of sequence.

\section{Unit II}

Interval: 324-U1349A-4R through 5R

Depth: 135.3-144.9 mbsf

The recovery of this unit is limited to $\sim 21 \mathrm{~cm}$ of highly brecciated sand-silt-claystone, one small piece of friable sandstone in Section 324-U1349A-4R-1, and two $(3-5 \mathrm{~cm})$ pieces of yellowish brown sandstone with volcaniclastics at the top of Section 5R-1. The pale yellow-brown brecciated material is calcareous and contains numerous weathered volcaniclastic fragments. These fragments include rounded granules of light green alteration clays, reddish scoria, and dark gray lithic clasts. Many gravel-sized angular pieces of red chert are mixed with the soft sand-siltclay pieces, presumably a result of the extensive drilling disturbance in this section. The two yellowish brown sandstone pieces recovered in Core 324U1349A-5R are similar in composition to the sandsilt-clay but have been lithified (Fig. F6).

\section{Unit III}

Interval: 324-U1349A-5R through 7R

Depth: 144.9-165.1 mbsf
Unit III is composed of calcite-cemented, lapillisized, clast-supported or matrix-supported volcaniclastic breccia, volcaniclastic sandstone, and an oxidized volcanic conglomerate. The volcaniclastic breccia is polymictic and contains granule- to pebble-sized clasts. Unit III is divided into two subunits (IIIa and IIIb).

\section{Subunit IIIa}

Subunit IIIa spans interval 324-U1349A-5R-1, $13 \mathrm{~cm}$, to $6 \mathrm{R}-2,6 \mathrm{~cm}$. The majority of this unit is gray lapillisized volcaniclastic breccia (Fig. F7) alternating with volcaniclastic sandstone. Thin sections reveal a minor biogenic component, including echinoderm and bryozoan fragments (Fig. F8). Rounded volcanic clasts are rare; however, we observed occasional armored clasts (Fig. F9). Secondary calcite is pervasive and observed in thin section with fibrous zeolites displaying low birefringence.

The volcaniclastic breccia is generally structureless and unsorted, although some normal grading and alternating medium-grained volcaniclastic sandstone and volcaniclastic breccia is present (Fig. F8). Clasts are mainly granule to pebble sized and show a variety of colors, such as red, gray, green, black, and brown. They exhibit varying degrees of roundness, mostly subangular to subrounded basalts, and vesicularity. Alteration of the primary volcanic material is common, though some clasts do appear relatively "fresh." The sandstones, and in some cases moderately sorted lapillistones, exhibit both normal and reverse grading. Volcaniclastic sandstones are sometimes laminated and often normally graded. Reverse grading is most common in Section 324-U1349A-5R1.

\section{Subunit IIIb}

Subunit IIIb is mainly composed of altered yellowish red volcaniclastic conglomerate (interval 324U1349A-7R-1, 6-96 cm). A textural and compositional change occurs at the top of this subunit. Interval 324-U1349A-6R-2, 9-26 cm, is composed of highly weathered sand-silt-clay material. The uppermost part of this crumbly material (interval 324U1349A-6R-2, 9-14 cm) is gray-brown and appears gradational from the gray volcaniclastic rocks of Subunit IIIa above to the more oxidized materials that characterize Subunit IIIb. Directly below the gray zone, a pink-orange, very crumbly silty sandstone with clay and few granule-sized altered volcaniclastics is observed. This material contains abundant yellow and red $\mathrm{Fe}$ oxyhydroxide/oxide minerals and displays a pedogenic texture typical of poorly developed paleosols (Fig. F10). Secondary calcite is present 
both as cement with micritic texture and as wellformed $<1 \mathrm{~mm}$ rhombic crystals.

With the exception of interval 324-U1349A-7R-1, 0$6 \mathrm{~cm}$, where pink chert fall-in is present, the remainder of Subunit IIIb is composed of polymictic conglomerates. The majority of the clasts in this subunit are partly to highly oxidized volcaniclastics; however, clasts of rounded mudstones and siltstones are also present. The conglomerate spanning interval 324-U1349A-7R-1, 6-60 cm, is moderately to poorly sorted (Fig. F11). Most clasts are cemented with pale yellow micrite, although light gray recrystallized calcite is also present as cement. It is important to note no zeolites were observed in thin section. Marine fossils make up a minimal component as rounded granules. A few thin $(1-2 \mathrm{~cm})$ layers of imbricated clasts are present within this interval.

Below the conglomerate, the lower portion of Section 324-U1349A-7R-1 becomes a structureless, matrix-supported, very poorly sorted volcaniclastic breccia. The matrix is mainly granule sized, and the clasts are mainly pebble sized. A very large $(\sim 8 \mathrm{~cm})$ subangular red clast, rich in titanomagnetite, is present at $60-70 \mathrm{~cm}$ in this section (Fig. F11) and has the highest magnetic susceptibility measured at Site U1349 (see "Physical properties").

\section{Unit IV}

Interval: 324-U1349A-7R through 14R

Depth: 165.1-221.7 mbsf

\section{Subunit IVb}

A thin $(13 \mathrm{~cm})$ interval of pale brownish gray bioclastic limestone was recovered at the top of Section 324-U1349A-9R-1, between igneous Subunits IVa and IVc. This interval, although poorly recovered, may represent a sedimentary interbed as thick as 6 $\mathrm{m}$, based on downhole logging data (see "Downhole Logging"). The limestone is matrix supported and contains abundant biogenic clasts, including shallow-water fauna such as bryozoans, echinoderms, and bivalve fragments (Fig. F12). Palagonite (altered volcanic glass shards) and small feldspar crystals are also found. Ooids with concentric laminated rims are present, and many of the biogenic grains also have cement coatings. The limestone is well sorted; all clasts are subrounded to rounded in shape and show signs of reworking. The matrix is a fine-grained calcite with some secondary calcite cement. The sedimentary contacts with the over- and underlying basalts were lost during coring; however, sediment of a similar type infills vesicles in several sections of the basalts spanning igneous Subunits IVa, IVc, and Unit V (see "Igneous petrology").

\section{Interpretation}

The basalts in Unit IV are highly oxidized and vesicular, suggesting emplacement in either a subaerial or very shallow marine setting. The oolitic limestone interbeds between flows at the top of Unit IV indicate a very shallow marine setting. The coarse volcaniclastic deposits that make up Units II and III show evidence of sorting and oxidation, suggestive of volcanism and deposition in a shallow-marine (Units II and III) or subaerial (top of Subunit IIIb) environment. The lithologies present in Unit I are consistent with deposition in a fully pelagic marine environment after volcanic activity on Ori Massif had ceased.

\section{Unit I}

The chert, chalk, and calcareous ooze comprising Unit I is suggestive of a fully marine, pelagic depositional environment and were likely deposited once the volcanic edifice had subsided below the photic zone. The dominantly red cherts suggest low sedimentation rates in an oxic environment. The original, well-bioturbated sediment, preserved as porcellanite patches within the silicified cherts, further suggests that the benthic depositional environment was well ventilated. The silica in the cherts is likely sourced from radiolarians, as evidenced by the circular fossil ghosts preserved in some horizons. This unit is similar in composition, recovery, and age to the upper cores from Unit I at Site U1348 and may represent the same stratigraphic unit as seen at Tamu Massif.

\section{Unit II}

Poor recovery in Unit II makes interpretation of the depositional environment challenging; however, the material is different enough from that of Unit III to warrant a separate unit division. The reddish brown color of the sediment suggests deposition in an oxic environment, consistent with subaerial or shallowmarine deposition. Clasts in the lithified sandstone (Core 324-U1349A-5R) are clearly of volcanogenic origin. Their subangular shape suggests a short transportation distance and minimal reworking prior to deposition.

\section{Unit III}

Unit III consists of coarse volcaniclastic sandstones and conglomerates that range from gray to reddish brown and are mainly composed of polymictic volcanogenic clasts. These clasts are generally subrounded to subangular in shape. This facies is considered epiclastic, as the rocks contain a variety of different types of clasts, presumably sourced from 
different parent materials. The rocks in this unit are likely to have been deposited in a subaerial to very shallow marine environment.

\section{Subunit IIla}

The volcaniclastic breccias and sandstones form alternating layers of Subunit IIIa, displaying normal and reverse grading and occasional fine laminations. The depositional mode, interpreted as a mixture of low-density turbidites (Bouma, 1962) and high-density turbidites (Lowe, 1982), requires submarine deposition where hydraulic sorting could occur. Thin flow units $(3-50 \mathrm{~cm})$ are likely to have been deposited by low-density turbidity currents, whereas the thicker flow units (from $10 \mathrm{~cm}$ to $1 \mathrm{~m}$ ) likely represent high-density turbidites. Flow unit boundaries are gradational and often amalgamated, indicating a high deposition rate. Armored volcanic clasts and red scoria are present, providing evidence for subaerial or explosive, very shallow marine volcanism.

\section{Subunit IIIb}

The upper part of Subunit IIIb is composed of highly weathered silty sand with clay and granules of subangular to subrounded altered volcaniclastics. These components, coupled with the highly oxidized nature of the deposit and pedogenic textures, suggest the beginnings of soil development on top of the oxidized conglomerates below. The recovered interval 324-U1349A-6R-2, 18-26 cm, contains several features typically associated with the B horizon in soils. For example, if we assume the conglomerate beneath is the parent material, the sediment in this interval shows obliteration of much of the original rock structure. The material appears to have experienced alteration that allowed the development of clay minerals in addition to mechanical weathering which would have created the abundant silt- and sand-sized grains (Soil Survey Division Staff, 1993). The red coloration is most likely related to the presence of numerous sesquioxides or oxyhydroxide minerals rich in $\mathrm{Fe}, \mathrm{Al}$, and $\mathrm{Mn}$. Often, water draining through a developing soil causes displacement of metals that collect at some depth in the subsurface and form oxyhydroxide coatings on the sedimentary grains (Soil Survey Division Staff, 1993). The final evidence that this interval is a paleosol comes from the overall brittleness of the sediment and the blocky structures that characterize its texture (Retallack,1991). Because the material directly below this sediment was not recovered, further work is required to confirm our interpretation of it as a paleosol. A complete assessment of the mineralogy, trace metal composition, and/or oxygen stable isotopes will confirm or disprove our interpretation.
The rest of Subunit IIIb is composed of graded to structureless altered yellowish red volcaniclastic conglomerate and breccia. The clast-supported, often laminated, and graded conglomerates are indicative of deposition in a subaqueous environment. The presence of imbricated clasts in these layers suggests deposition by strong unidirectional currents. The bottom of the subunit is structureless, matrix supported, and poorly sorted and therefore is interpreted as a debris flow deposit (Middleton and Hampton, 1976; Lowe, 1982).

The yellowish red color of the volcaniclastic conglomerate indicates an oxidative, likely subaerial, environment. However, deposition of imbricated clasts requires transport by water. Development of a paleosol requires subaerial exposure of a rock surface; therefore, we suggest that many of the clasts comprising the lower part of Subunit IIIb were sourced from land but deposited in a very shallow water environment. These rocks were subsequently exposed subaerially, which allowed for oxidation and soil development.

\section{Subunit IVb}

The limestone bed in Section 324-U1349A-9R-1 lies within the basaltic "basement" but apparently represents a break in lava flow emplacement during which marine sedimentation could occur. The presence of round grains and ooids is suggestive of deposition in a very shallow, agitated marine environment. The dominance of bioclastic components associated with shallow-marine environments (e.g., echinoderms and bryozoans) is consistent with this interpretation. Other sedimentary intervals from Unit IV (e.g., interval 324-U1349A-7R-2, 27-35 cm) suggest successive periods of lava emplacement and quiescence when limited normal marine sedimentation resumed.

\section{Paleontology}

Sediments at Site U1349 are composed of reddish cherts and pinkish nannofossil ooze (Cores 324U1349A-1W through 4R; stratigraphic Unit I; see "Sedimentology") and underlying siliciclastic and volcaniclastic sediments (Cores 4R through 7R; stratigraphic Units II and III). Shipboard calcareous microfossil studies focused mainly on the Unit I sediments, and calcareous nannofossil study extended to Units II and III.

Calcareous nannofossils in the sediments at Site U1349 are rare to common in abundance and are poorly preserved throughout Unit I and barren in underlying Units II and III. Planktonic foraminifers from Unit I are very high in abundance and diversity 
with good preservation in the nannofossil ooze of Core 324-U1349A-2R, whereas those from other chert-rich levels are poorly preserved and/or low in abundance. The zonal marker species and other agediagnostic species of planktonic foraminifers strongly indicate that Core $2 \mathrm{R}$ is correlated to the middle-late Albian transition. Further age constraints on other examined levels above and below are also possible by some age-diagnostic species, allowing the Unit I sediments to be dated to the Albian-Cenomanian. The ooze of Core $2 \mathrm{R}$ yields a diverse benthic foraminifer assemblage, and the estimated bathymetric range is middle bathyal.

\section{Calcareous nannofossils}

Calcareous nannofossils in the sediments at Site U1349 are rare to common in abundance and poorly preserved throughout Unit I (Cores 324-U1349A-1W through $4 \mathrm{R}$ ). The underlying sediments (Units II and III) are barren of calcareous nannofossils.

The dominant taxon in the analyzed samples is Watznaueria barnesae, a typical Cretaceous taxon; few other species are identified (Table T2). In Sample 324-U1349A-1W-1, 9-10 cm, only the additional presence of Watznaueria britannica points to the Lower to mid-Cretaceous. The pinkish ooze below (Sample 324-U1349A-2R-1, 0-1 cm) is mainly composed of subrounded abiogenic calcite particles together with frequent to abundant and highly overgrown specimens of Reinhardites levis (upper Campanian to Maastrichtian) and occasionally abundant Diazmolithus lehmanii (entire Cretaceous) and Cretarhabdus striatus (Aptian to Cenomanian). Hence, the assignment of chronostratigraphic range is difficult based solely on calcareous nannofossils. In Sample 324-U1349A-3R-1, 5-6 cm, only the presence of Rhagodiscus robustus, in addition to $W$. barnesae, provides a potential range from the Barremian to upper Albian (Zone NC5-Subzone NC10a). The lowermost fossiliferous horizon is Sample 324-U1349A4R-1, 9-10 cm, which contains some specimens of Rotelappilius sp. and Zeugrhabdotus sp. that are common constituents of the entire Cretaceous assemblage.

\section{Foraminifers}

\section{Planktonic foraminifers}

The planktonic foraminifer record from stratigraphic Unit I at Site U1349 is marked by a mid-Cretaceous assemblage (Table T3). Although foraminifer occurrence is limited by chert-rich lithologies, pinkish nannofossil ooze in Core 324-U1349A-2R shows ex- ceptionally high abundance and diversity of a middle-late Albian assemblage with good preservation.

Sample 324-U1349A-1W-1, 5-9 cm (chert-encrusting pinkish chalk), yields moderately to poorly preserved individuals of hedbergellids and a poorly preserved rotaliporid specimen. The stratigraphic range is tentatively assigned to the upper Cenomanian (Rotalipora globotruncanoides Zone).

Planktonic foraminifers from Sample 324-U1349A2R-1, 1-2 cm, are marked by high abundance and diversity with good preservation and correlated to the middle-upper Albian transition. The faunal elements are predominantly the ticinellids (Ticinella primula, Ticinella madecassiana, and Ticinella roberti) with abundant Hedbergella wondersi and Globigerinelloides bentonensis as well as rare hedbergellid taxa. It is noteworthy that rare individuals of the ticinellids exhibit a transitional morphological state to Biticinella breggiensis (i.e., primary apertural openings at both umbilical and spiral sides but not fully connected to each other). This level is therefore very close to the top of the Ticinella primula Zone. Foraminifer specimens with relatively good preservation were also retrieved from Sample 324-U1349A-4R-1, 9-10 cm. The assemblage is marked by the occurrence of few T. madecassiana together with forms assignable to Hedbergella rischi (sensu Bellier and Moullade, 2002). The combination of these two planktonic taxa can be interpreted as indicating the early part of the $T$. primula Zone.

\section{Benthic foraminifers}

As is the case of planktonic foraminifers, a highabundance diverse benthic foraminifer assemblage is recorded from the pinkish nannofossil ooze of Sample 324-U1349A-2R-1, 1-2 cm (Table T4). This assemblage is characterized by relatively large sized individuals. The most dominant are calcareous trochospiral taxa, which are largely Osangularia and, subordinately, Gyroidinoides. Some nodosariids (Lenticulina, Saracenaria, Planularia, Psilocitharella, and fragmentary Laevidentalina) constitute a subordinate proportion of the assemblage (10\% of total benthics). Identified agglutinated taxa are mainly abundant Gaudryina as well as rare Ammosphaeroidina and small-sized Spiroplectinella. The dominance of Osangularia and presence of some nodosariids most likely indicate a middle bathyal setting (Sliter and Baker, 1972; Sikora and Olsson, 1991). Other faunal elements are also conformable with a coeval middle bathyal assemblage along the Atlantic margins (Holbourn et al., 2001). 


\section{Igneous petrology}

\section{Stratigraphic unit description and volcanology}

In this site report, stratigraphic units are given Roman numbering (Units I-V), whereas the small-scale lithologic units identified during core description are given Arabic numbering (Units 1-32). We identified these lithologic units on the basis of sedimentological changes or, in the case of volcanological units, criteria including the presence of chilled margins or contacts, identifiable flow tops, vesicle distribution, and the occurrence of intercalated volcaniclastic or sedimentary horizons. When considered together, these criteria define the various sizes of individual volcanic inflation units. Accordingly, in the volcanic context, the term "stratigraphic unit" is used to combine consecutive inflation units of similar character into lava packages or eruptive successions (see "Igneous petrology" in the "Methods" chapter).

Hole U1349A was drilled near the top of Ori Massif, a large volcanic edifice the size of the Big Island of Hawaii (Fig. F1). The uppermost succession of recovered sediment commences with an Lower Cretaceous sequence consisting of pelagic red chert and nannofossil ooze (stratigraphic Unit I) followed by low recovery ( $2 \%)$ of clay-, silt-, and sandstone and fragments of lithified calcareous sandstone (stratigraphic Unit II), which also includes a component of granular volcaniclastic material (Fig. F5). Beneath these upper units, sediment recovery improves greatly ( $62 \%$ beginning with Core 324-U1349A-5R) and reveals a complex succession (stratigraphic Unit III) that, in its upper part, begins with $\sim 8 \mathrm{~m}$ of gray-green volcaniclastic sediment containing normally graded beds (each beginning with gravel-sized particles), which may have been deposited as turbidites. These pass downward into Subunit IIIa, consisting of layered, coarse volcanic sandstone containing abundant pebble-sized clasts of basalt and hyaloclastite; this subunit has reddish (ferric) iron staining in its lower part. Subunit IIIb consists of $\sim 1 \mathrm{~m}$ of reddish orange oligomict volcanogenic conglomerate. A marked reddened horizon in the upper part of this subunit is interpreted as a possible paleosol and may indicate oxidative alteration in a subaerial eruptive environment. Beneath this horizon, the conglomerate is weathered brown throughout, becomes coarser, contains subrounded cobble-sized volcanic clasts (including magnetite- and plagioclase-rich examples), and lies unconformably upon a highly vesicular weathered basalt flow (i.e., the top of stratigraphic Subunit IVa). For information on the sediments in Units I-III (Fig. F5) see "Sedimentology."
Volcanic basement was reached at $165.1 \mathrm{mbsf}$ (Sample 324-U1349A-7R-1, 96 cm) (Fig. F13). Drilling continued into a $\sim 54 \mathrm{~m}$ succession of highly altered $(\sim 20 \%-60 \%)$ vesicular lava flows intercalated with thin beds of carbonate-rich sand- and mudstones (Unit IV) and underlain by $\sim 29 \mathrm{~m}$ of flow breccias with abundant altered olivine and (relatively) higher $\mathrm{MgO}$ contents (Unit V). The actual contact between the reddish oligomict conglomerate and the topmost basalt flow was not recovered, but the majority of flow units in the underlying vesicular lava succession (Unit IV) exhibit a brownish orange ferric alteration, as well as a number of deeply reddened (possibly weathered) flow tops. In addition to weathering horizons, several flows are intercalated with carbonate-rich sedimentary horizons.

The following description first outlines Unit IV in terms of an upper lava succession, consisting of thin, highly vesicular lava flow units (Subunit IVa), and a lower lava succession, characterized by thicker lava inflation units (Subunit IVc) affected by pervasive oxidative weathering; Subunits IVa and IVc are distinguished by an intervening layer of oolitic limestone (Subunit IVb). Second, the description outlines Unit V, the underlying volcanic flow breccias and massive olivine-phyric picritic lava pods, which have been affected by a different gray-green clay-rich alteration.

\section{Vesicular lava succession (stratigraphic Unit IV, lithologic Units 4-31)}

A total of $\sim 54 \mathrm{~m}$ of highly altered, $\sim 0.5-6 \mathrm{~m}$ thick vesicular lava units were recovered in this succession (Figs. F13, F14). The succession may be divided into an upper ( $\sim 5 \mathrm{~m}$; Subunit IVa) and lower ( 49 m; Subunit IVc) lava section, respectively lying above and below a $\sim 6 \mathrm{~m}$ oolitic limestone intercalation (as determined from downhole logging data; Subunit IVb). Pahoehoe-like flow structures are preserved in the upper parts of the thinner flow units that occur in both Subunits IVa and IVc. These pahoehoe lava flow tops are characterized by a particularly high degree of vesicularity (>40\%-75\%) and display a range of structures such as lava mixing and brecciated vesicular upper crusts (Figs. F15, F16). These inflation units, with rubbly brecciated upper crusts and massive amygdaloidal interiors, are more clearly evident in cores with higher recovery, such as Core 324U1349A-13R (Fig. F16). The vesicular texture of the upper lava sections is "spongelike," consisting of mainly horizontal and intensely vesiculated zones several tens of centimeters thick. In addition, these sections contain rare zones of stretched/distorted vesicles that help to reveal folds, brecciated zones, 
and partially digested pahoehoe crusts in the lava flow tops.

In addition to the $\sim 6 \mathrm{~m}$ thick oolitic limestone intercalation, Subunit IVb, many other smaller intercalations of limestone containing sand-size peloids and oolites occur throughout Subunit IVa and the topmost part of Subunit IVc. These limestone deposits often fill voids and vesicles in the uppermost few centimeters of the lava flows, these being generally highly vesicular and often reddened. In these intervals the usual calcitic or micritic vesicle infilling is absent, and infilling is dominated by clays instead.

X-ray diffraction (XRD) data reveal mostly Fe oxyhydroxides (low-crystallinity hematite and goethite), together with montmorillonite, halloysite, and traces of some primary igneous phases such as feldspar (interval 324-U1349A-10R-1, 1-35 cm). In these reddened lava-top horizons, this combination of secondary minerals is consistent with low-temperature subaerial alteration.

Thin sections reveal that the lavas of Unit IV contain $3 \%-5 \%$ olivine phenocrysts set in a matrix that contains many "ophimottle" aggregates (see "Petrography and igneous petrology") of subophitic clinopyroxene and plagioclase. In addition, Sections 324U1349A-9R-1 and 9R-2 (Subunit IVc) contain discrete vesicular horizons apparently disrupted by latestage magma mingling and postemplacement injection and movement within the lava inflation units themselves. These zones may represent disrupted sections of partially or fully solidified crust between which a later, degassed magma appears to have been injected. In particular, the highly vesicular upper part of an $\sim 8 \mathrm{~m}$ thick inflation unit in Core 324U1349A-11R preserves a range of magma mixing features, showing intrusion and disruption of the surrounding, more vesiculated horizons (Fig. F15). This heterogeneous flow exhibits several mixing contacts consisting of sparsely vesicular, microcrystalline, and reddish orange basaltic lava intruding into a more highly vesicular and sparsely olivine-phyric basalt that evidently is of another lava type. However, inductively coupled plasma-atomic emission spectroscopy (ICP-AES) geochemical data indicate that these two lava types are essentially similar, suggesting that the observed differences in lava type are most probably caused by differences in vesicularity and degree of alteration rather than petrogenesis.

Thicker lava inflation units occur toward the bottom of the lower lava section (Subunit IVc). For example, improved recovery $(\sim 60 \%-80 \%)$ in Cores 324U1349A-10R through $12 \mathrm{R}$ shows that this subunit contains three lava inflation units that are between 4 and $6 \mathrm{~m}$ thick, whereas the lowermost succession within Core 13R consists of units that are between 1 and $3 \mathrm{~m}$ thick (Fig. F16). These thicker inflation units also have highly vesicular tops but are sparsely vesicular in their interiors and range in coloration from brown to gray-green depending upon the degree and style of alteration. Alteration is particularly complex in these lower massive units. For instance, lithologic Unit 22 ( $\sim 6 \mathrm{~m}$ thick inflation unit) between intervals $324-\mathrm{U} 1349 \mathrm{~A}-11 \mathrm{R}-2,87 \mathrm{~cm}$, and 11R$6,129 \mathrm{~cm}$, contains not only primary magma mixing features but also oxidative reddening horizons, a pervasive brown alteration color, abundant veining, and zeolite infilling along fractures and in vesicles (see "Alteration and metamorphic petrology").

The contact between the lowermost flow and the underlying flow breccia sequence (Unit V) is not preserved, but the alteration described above continues farther down, affecting the topmost part of the underlying unit by imparting a similar brownish color (Sections 324-U1349A-14R-1 to 14R-3).

\section{Flow breccia sequence (stratigraphic Unit V, lithologic Unit 32)}

Unit $\mathrm{V}$ consists of the interval from Section 324U1349A-14R-1 to the bottom of hole. It is a $\sim 25 \mathrm{~m}$ thick, poorly sorted alternating assemblage of roughly equal proportions of small, irregular lava inflation units (pods) and fragmental basalt breccia in which no internal bedding or grading can be discerned (Figs. F17, F18). In the core the discernible lava pods are vesicular and between 0.5 and $2 \mathrm{~m}$ thick (average $\sim 1 \mathrm{~m}$ ), which is probably an accurate representation of their true dimension because core recovery was very good ( 75\%-90\%). The cores of these lava pods usually have spherical vesicles that grade into deformed, elongate vesicles along the outer margins. Their margins typically consist of fragmented basaltic lava crust that exhibits jigsaw-fit textures, thus indicating that relatively little transport occurred after their emplacement. The margins of these pods appear to have chilled against the matrix of basaltic breccia onto, or into, which they were emplaced. Glass shards are generally not easily discernible in the breccia because of alteration but are identifiable in the matrix of the fragmental horizons (see "Petrography and igneous petrology"). Fine granule- to sand-sized fragments, commonly occurring in pockets, are densely concentrated along the margins of the more disintegrated inflation units.

The fragmental areas of the flow breccias are typically between 0.1 and $1.3 \mathrm{~m}$ thick (average $=0.8 \mathrm{~m}$ ). The constituent basalt fragments are mostly angular and several centimeters in size $(0.1-10 \mathrm{~cm})$. Several horizons consist of fractured, cobble-size basaltic fragments. All the brecciated horizons are monomict (i.e., they contain vesicular hyalobasalt clasts or glass 
shards), poorly sorted, and may be either clast or matrix supported depending upon the relative proportions of fine to coarse constituents. The clasts display a wide range of morphologies that range from blocky jigsaw-fit basalt clasts to irregular clasts with wavy and subplanar margins. Single basalt fragments exhibit mostly fragmented morphologies but preserve textural features that indicate they formed in situ (because adjacent fragments have contiguous shapes). Petrographic textures also reveal complex wavy and jigsaw-fit morphologies (Figs. F17, F18) at the micro scale, and many of the clasts with irregular morphologies (i.e., chipped hyaloclastite fragments) have thin dark green rims that may interpreted as chilled margins, typical of submarine eruptions. Therefore, Unit V is classified as a hyaloclastite pillow breccia.

\section{Preliminary assessment}

\section{Varying eruption environments (stratigraphic Units IV and V)}

The lava succession of Unit IV contains a variety of nonvolcanic features. These include reddening of many of the flow tops and evidence of shallow-water sedimentary intercalations. Oxidative alteration of lava tops is likely indicative of subaerial alteration and, coupled with the shallow-marine deposits preserved at the contacts of the uppermost lava units, suggests a littoral and/or periodically "emergent" environment during the development of the lava succession. Because the conglomerate of Subunit IIIb lies immediately on top of the lava succession and contains a putative paleosol within it, these features can be interpreted to represent a period of exposure and erosion following the emplacement of the lava succession. The variety of clast types within the conglomerate includes compositions that cannot be readily matched to the succession immediately below and so might indicate emergence and erosion of a volcanically complex terrain.

By contrast, Unit $\mathrm{V}$ is interpreted as an autoclastic volcanic breccia that involved fragmentation of semisolid or solid lava (Fisher, 1960). Flow breccia may be formed by nonexplosive fragmentation of flowing or recently solidified basaltic lava and preserves features that indicate disintegration and/or autobrecciation of coherent lava flows. This flow breccia is a distinct, heterogeneous unit with complex internal features that formed as part of a series of individual flows or injections into the unconsolidated hyaloclastite that underwent fragmentation. Importantly, the jigsaw-puzzle texture in many of the flow breccia fragments indicates there was minimal transportation after emplacement of the lava unit. The fracturing present within individual lava flows must, therefore, be caused by limited mobilization or mechanical friction within the unconsolidated materials, or else by contraction of lava pods during cooling. The highly fluidal shaped morphologies of some smaller clasts in the brecciated horizons suggest fragmentation took place while some parts of the flow were still partially molten. Such fragmentation appears to have taken place especially in the highly vesicular areas of the flow. Emplacement of these flow breccias could have resulted from autobrecciation processes in which effusive subaerial eruptions enter into submarine environments or, alternatively, gaseous explosions during submarine lava emplacement as part of a lava delta sequence, or possibly mass mobilization related to mass movement or seismic activity. However, the latter is least likely since many fragments indicate that postemplacement movement was minimal.

Accepting the above interpretations, the volcanic succession of Hole U1349A reveals a change from submarine eruption, producing a thick stack of autobrecciated lavas and hyaloclastite breccias, passing upward into a phase where thick inflation units developed (up to $6 \mathrm{~m}$ thick). These thick units have weathered surfaces, indicating that by this stage the succession had perhaps built itself above sea level. However, periodic marine incursion permitted deposition of carbonate sediments, which infilled voids, pockets, and vesicles within the exposed lava surfaces. The uppermost part of the lava succession therefore appears to be an interplay between subaerial exposure and very shallow marine conditions over a low-lying volcanic landscape. Further erosion then led to the development of the conglomerate, before reestablishment of marine conditions resulted in the deposition of the volcaniclastic sedimentary succession of Unit III.

\section{Determination of eruption depth for the highly vesicular lavas (stratigraphic Unit IV)}

One of the major questions relating to the volcanism at Shatsky Rise concerns the water depth in which the lavas were erupted. The high $40-75$ vol\% vesicularity or spongelike basalt lavas of Unit IV provide an opportunity to make an initial estimate of eruption depth using assumptions based on equilibrium degassing and the likely rapid quenching of outpouring magma. Vesicle content of submarine glasses recovered from known eruption depths on the eastern rift zone of Kilauea Volcano (Hawaii) has been shown to agree with vesicularities calculated from degassing models in which the pre-eruptive $\mathrm{H}_{2} \mathrm{O}$ and $\mathrm{CO}_{2}$ contents have been constrained (Wallace, 1998). This correlation also may be applied to the vesicularity measurements of the Unit IV lavas (Fig. F14) and 
thus used to estimate the eruption depths. Precise estimation would require determination of $\mathrm{H}_{2} \mathrm{O}$ and $\mathrm{CO}_{2}$ concentrations for the lavas, but a preliminary estimate is possible by using the degassing curves for different proportions of $\mathrm{H}_{2} \mathrm{O}$ and $\mathrm{CO}_{2}$ contents of basaltic melt provided by Wallace (1998) (Fig. F19). Thus, assuming that $\mathrm{H}_{2} \mathrm{O}$ concentrations in Shatsky Rise magma are typical for mid-ocean-ridge basalts (MORBs) elsewhere (i.e., 0.05-0.4 wt $\% \mathrm{H}_{2} \mathrm{O}$; Danyushevsky, 2001), the observed $40-75 \mathrm{vol} \%$ vesicularity suggests that the lavas could have formed at pressures below 15-20 bar, corresponding to water depths of less than 150-200 mbsl (Fig. F19). It should be emphasized, however, that estimated eruption pressures are highly dependent on the assumed initial melt $\mathrm{H}_{2} \mathrm{O}$ concentrations; if the magma initially were more hydrous, deeper eruptions would be predicted.

\section{Petrography and igneous petrology}

In Hole U1349A, true extrusive basement (Units IV and $\mathrm{V}$ ) consists of $\sim 84 \mathrm{~m}$ of mainly pillow lavas, massive flows, and flow top breccias. An overview of these volcanic basement units and the abundances of olivine and clinopyroxene phenocrysts in these rocks are shown in Figure F20 and Table T5. Polished thin sections were prepared of rims and interiors of 55 of these rocks, including all intervals where ICPAES analyses were made. A summary table of thin section descriptions of the volcaniclastic rocks is given in 324TS.XLS in LOGS in "Supplementary material," and the contacts between units are described in 324UNIT.XLS in LOGS in "Supplementary material." The principal igneous lithologies identified in thin section are

- Subunit IIIb: varieties of lithic, subaerial, and glassy submarine volcanic rocks found in a polymict conglomerate derived partly from detrital and partly from nearby active volcanic sources;

- Subunit IVa: highly vesicular olivine-spinel basalt, extensively oxidized and altered, with textural aspects suggesting both subaerial and submarine extrusion;

- Subunit IVc: generally fine- to medium-grained olivine-spinel phyric basalts, some of which contain unusually coarse patches of plagioclase-clinopyroxene intergrowths exhibiting ophitic texture and all of which are variably, but extensively, oxidized and altered; and

- Unit V: dark khaki-green olivine-spinel phyric basalt and/or picrite that is extensively altered.

Despite the alteration, primary petrographic features of the basalts can be recognized. The following describes the rocks as they were recovered sequentially downhole and emphasizes their primary igneous features based on thin section observation. Identification of the least altered igneous minerals and the influence of alteration on igneous textures will also be covered. The most outstanding petrographic features of the rocks are

- Occurrence of ferroandesite clasts of (likely) tholeiitic or (less likely) alkalic parentage in the oligomict volcanogenic conglomerate of Subunit IIIb;

- Extraordinary vesicularity of the pillow lava crusts, up to $\sim 75 \%$, in rocks of Subunit IVa at the top of the basement, which together with interbedded sedimentary rock and a capping paleosol are likely to be indicative of eruption in very shallow water and, in part, subaerially;

- Possible evidence of superheating that might have triggered some of the high vesicularity internally in the lava flows and along contacts between magmas of different temperature/texture that were incompletely mixed prior to eruption;

- Brown Cr spinel and altered olivine that have a ubiquitous and abundant presence in all extrusive rocks, whereby some rocks of Units IV and V carry enough olivine to be classified (originally) as picrite.;

- Occurrence of ophimottle textures throughout Unit IV involving coarse-grained ophitic intergrowths of plagioclase and clinopyroxene set as loose networks within a finer grained matrix; and

- Possibility of high-temperature alteration affecting all lithologies and resulting in the pervasive deep orange to red-brown staining in Units III and IV, as indicated by the presence of abundant secondary hematite and complex oxy-exsolution of titanomagnetite in Unit IV, which in turn contrasts with the chloritic nonoxidative alteration and the disappearance of titanomagnetite in Unit $\mathrm{V}$.

\section{Volcaniclastics and oligomict volcanogenic conglomerate (stratigraphic Subunit IIIb, lithologic Unit 3)}

In thin section, both a large igneous clast (Fig. F21A, F21B) and a smaller clast of the conglomerate of Subunit IIIb (Fig. F21C, F21D) have abundant small plagioclase crystals arranged in a typical trachytic texture. Both clasts have abundant titanomagnetite, which is intact despite oxidative alteration of material between plagioclases (evident in the reddish background tint caused by internal reflections when using reflected light in Fig. F21B, F21D). The approximate modal abundance of the feldspar is $60 \%-$ $70 \%$, based on reflectivity. Different portions of the 
clasts have abruptly different plagioclase modes, sizes, and extent of crystallinity (Fig. F21A), and the plagioclase crystals flatten and turn to parallel vesicle margins where they concentrate to form narrow plagioclase-plated rims. The highly reflective titanomagnetite is skeletal in both samples and is as large as or larger than the plagioclase crystals, an attribute not typical of basalt, but rather of felsic differentiated lavas. The basaltic clasts are aphyric and have no residual clinopyroxene in between the small plagioclases that survived alteration. The large clast has several elongate vesicles as long as $1 \mathrm{~cm}$, whereas the smaller clast in the conglomerate is nonvesicular.

Given all the basalt drilled at six sites during Ocean Drilling Program (ODP) Leg 198 and Expedition 324, these conglomerate clasts provide the only evidence for an extended range of differentiates at Shatsky Rise. The following brief inventory was made of all the rounded and irregular clasts, chips, and shards up to $1 \mathrm{~cm}$ in size within the conglomerate of Subunit IIIb, which are cemented together by calcite:

- Several rounded clasts of ferroandesite, as described above.

- Angular palagonitized granular hyaloclastite and hyaloclastic sandstone.

- Some rounded and some angular lithic plagioclase-phyric basalt.

- Lithic olivine-spinel-plagioclase phyric basalt, with altered olivine.

- Angular and broken plagioclase phenocrysts and glomerocrysts.

- Rounded lithic grains of mudstone.

- Vesicular basalt cemented by quartz.

Palagonite and oxidation of most basalt and ferroandesite clasts in the conglomerate formed in situ and accompanied the rather similar alteration of immediately subjacent rocks.

\section{Calcite and amygdule fillings in top of volcanic basement (stratigraphic Subunit IVa, lithologic Unit 4)}

Thin Section 206 (Sample 324-U1349A-7R-1, 112$115 \mathrm{~cm}$ ), taken $\sim 20 \mathrm{~cm}$ below the top of volcanic basement in Unit IV, has a $1 \mathrm{~cm}$ wide crack and some large amygdules that are filled with calcite-cemented bioclastic material containing fossil fragments possibly derived from echinoderms and bryozoans. Some of the amygdules are also partly filled with palagonitized hyaloclastic sand, now cemented with calcite. The sand consists of former angular glass shards now entirely replaced by orange (partly fibrous) palagonite (Fig. F21E). About 10\% of the material is dark red to brown angular fragments; these formerly had quenched spherulitic textures like those in zones of pillow basalts just adjacent to glass margins. A few more coarsely crystalline fragments (Fig. F21F) may be remnants of the deeper, more crystalline portions of pillows, or else fragments of fine-grained subaerial lava flows. The interiors of all basaltic fragments are nonvesicular, although some curving exterior outlines may have formed as bubble walls.

All of these sedimentary rocks and the extraordinary vesicularity of the topmost basalts in Unit IV indicate that eruptions occurred at, or near to, wave base. An ocean island must have been nearby in order to provide such a lithologically diverse volcanic detritus to a shallow offshore depositional environment that also supported a large calcareous macrofaunal assemblage. That assemblage, perhaps transported in alongshore currents, encountered and incorporated hyaloclastic material derived by eruption and quenching to volcanic glass in aquagene conditions. This mix of material covered the topmost basalt flow of Unit IV, after which the whole assemblage was soon altered and cemented.

\section{Vesicular upper lava succession (stratigraphic Subunit IVa, lithologic Units 4-12)}

Subunit IVa comprises eight lava inflation units defined primarily by highly vesicular flow tops with more massive interiors. In Core 324-U1349A-7R, six of the units have an average curated thickness of $\sim 0.7 \mathrm{~m}$. The more massive interiors have intervals with somewhat lower vesicularity and distinct variations in color from darker red to lighter brownish red that appear both as splotches or as streaks or bands trending diagonal to the core. The darker bands are usually narrower and slightly less vesicular than surrounding rock and typically outline lighter colored areas with contrasting sizes and spacings of the vesicles. These inflation units seem to have extruded as "lava foam" and may have become multicolored by differential oxidization upon eruption. The foam probably spilled over onto itself and tumbled around, a process that mixed together the bands with different vesicularity and color.

One thin section $2.31 \mathrm{~m}$ below the top of basement exhibits textural variability indicating very rapid cooling (Thin Section 209; Sample 324-U1349A-7R$3,39-43 \mathrm{~cm})$. The photos in Figure F22 show increasing crystallinity and development of crystal morphologies within $\sim 2 \mathrm{~cm}$ of the edge of the thin section. Although the rock in Figure F22A is highly oxidized and vesicles are filled with calcite, the remnants of coalesced spherulites can still be identified. The few plagioclase crystals in the thin section are very tiny. Across the thin section, a successively larger size and higher abundance of clumps of plagi- 
oclase crystals can be seen (Fig. F22B-F22D). The rock also contains $\sim 1 \%-3 \%$ olivine phenocrysts and small, intergrown crystals of $\mathrm{Cr}$ spinel. A question is whether it represents the chilled margin of a flow or pillow that erupted underwater. Quenched rims with (altered) glass are not evident in the cores of Hole $\mathrm{U} 1349 \mathrm{~A}$, and it is possible that both vesiculation and intense alteration obliterated any glassy rims that were formed. Even so, the spherulitic margin shown in Figure F22A and the presence of hyaloclastite in cracks and vesicles require very high rates of cooling for crystallization to have been nearly or entirely suppressed.

Olivine phenocrysts in Subunit IVa are invariably altered to fibrous, moderately birefringent clays and red Fe oxyhydroxides (Fig. F23A, F23B). The red color is often most intense along crystal margins, a characteristic that in older studies (e.g., Baker and Haggerty, 1967) allowed it to be designated as iddingsite. Spinel is unaltered, but its dark amber brown matches the colors in altered surroundings. Each thin section contains a dozen or more grains and in some cases several grains per olivine crystal. The spinels retain cubic or octahedral shapes and usually occur associated with or within olivine (Fig. F23C, F23D) and often in clusters, but they also are isolated in the groundmass. Some crystals as large as $100 \mu \mathrm{m}$ in diameter.

\section{Vesicular lower lava succession (Subunit IVc, lithologic Units 14-31)}

Externally, the rocks of Subunit IVc appear to be a continuation of the variegated and foamy lavas of the upper lava succession of Subunit IVa. However, dark bands and streaks of relatively fine grained and less vesicular rock are prominent in almost every section of core. These rocks appear to be mixtures of physically dissimilar lava types. Throughout Subunit VIc, the criteria for recognition of cooling or inflation units were a combination of high vesiculation and occurrence of a deep and pervasive red alteration, the combined observations giving the appearance of deeply weathered scoriaceous flow tops. This alteration presented a severe problem to identification of minerals in hand specimen. Outlines of olivine phenocrysts are fairly obvious, but many flow interiors in which acicular plagioclase could be discerned also contained a myriad of small and obviously altered bright red specks, which thin section examination revealed to be Fe oxyhydroxide minerals often coated with hematite (see below for details).

\section{Pervasive alteration of olivine and the survival of spinel}

Thin sections show that almost everything but plagioclase (present as needles in the groundmass) is al- tered to a combination of clays and Fe oxyhydroxides. In reflected light, the percentage of reflective silicate minerals is usually small $(10 \%-40 \%)$, and nonreflective portions exhibit brown or red internal reflections (Fig. F23C, F23D), indicating the presence of abundant Fe oxyhydroxides in clays. In Figure F23C, plagioclase surrounding an altered olivine phenocryst is slightly darker than surviving interstitial clinopyroxene crystals. Elongate interiors of former glassy and crystalline material are now altered to dark brown and nonreflective secondary minerals. Only spinel survives unaltered.

\section{Ophimottled textures}

Many of the rocks of Subunit IVc are divided almost equally between finer grained and coarser grained groundmass domains, with the latter being distributed in loose networks across the thin sections. Whereas many rocks of previous sites drilled during Expedition 324 contain networks of intergrown plagioclase and clinopyroxene, in the coarser grained portions of these rocks the two are intergrown ophitically, in a fashion similar to that found in the centers of very massive flows, dikes, or gabbros. However, the domains of these intergrowths are visually surrounded by a dense speckling of Fe oxyhydroxides in the surrounding matrix of acicular plagioclase. This texture is termed "ophimottled," and the proportions of mottles clearly differ both within and between thin sections. For instance, in Figure F24A their distribution is defined by a difference in size and density of Fe oxyhydroxide grains to the left and right of a curving surface (delineated in part by the yellowish alteration). By contrast, the mottles in Figure F24D and F24E are larger and coarser grained.

Comparisons of individual mottles (Fig. F24) in transmitted and cross-polarized light are shown in Figure F25A-F25D, and between cross-polarized and reflected light in Figure F25E and F25F. Individual pyroxene crystals are $0.5-2 \mathrm{~mm}$, and the mottles consist of one or more of such crystals, which (partly) enclose narrow, acicular, elongate, and often stellate arrangements of plagioclase crystals. Figure F25E and F25F shows a mantling of smaller plagioclase crystals that are partially intergrown, with the central clinopyroxene and later-formed clinopyroxene crystals arranged in a rim that contains grains of titanomagnetite. It is important to note that the mottles observed in thin section lack any faceted crystal outline and so are not strictly phenocrysts or glomerocrysts.

These plagioclase-clinopyroxene mottles are reminiscent of the intergrown gabbroic clots recovered with interstitial glass from the Juan de Fuca Ridge (Dixon et al., 1986). Their grain size and textures are also 
similar to those in some portions of shallow gabbros recovered near the top of the gabbroic section of ocean crust exposed at Hess Deep, eastern equatorial Pacific (e.g., Natland and Dick, 1996). Accordingly, the mottles in Hole U1349A probably represent crystallization at shallow levels within a gabbroic mass beneath Ori Massif; however, this crystallization did not proceed to completion; instead, the network of interlocking plagioclase-clinopyroxene clumps in the partially crystallized magma was disrupted by a late magma injection and then carried with this to the surface. The titanomagnetite in Figure F25E and F25F represents a fairly advanced stage in the basalt differentiation, but the mottles were raised to the surface upon eruption by a much more primitive magma than the liquids that produced these complex mottles. In the final host liquid, both olivine and spinel were stable.

\section{Alteration of titanomagnetite}

Some of the titanomagnetite in the ophimottles is skeletal (Fig. F26A, F26B), which means that portions of the crystals enclosed either melt or melt inclusions at the time the clots were incorporated into the ascending liquids. After quenching at eruption, however, all traces of that melt were erased by alteration, and the titanomagnetite itself underwent oxyexsolution that may have been induced by the introduction of hot circulating fluids (Fig. F26B-F26D). Alternatively, these titanomagnetite crystals may have experienced an initial oxy-exsolution into solid solutions of ilmenite and magnetite before they were incorporated into the crystallizing lava. If the latter, the titanomagnetite crystals were well below solidus temperatures (but above $\sim 600^{\circ} \mathrm{C}$ ) at the time they were engulfed, and some of the features now shown in the minerals may have been inherited from these deeper processes.

Exsolution features can also be discerned in both the coarser oxide mineral grains of the mottles and the much smaller, skeletal, former titanomagnetite of the rest of the rock. The oxides in the mottled intergrowths and skeletal groundmass titanomagnetite therefore have similar features. In some larger crystals of the mottles, the oxy-exsolution produced a criss-crossing grid of four different oxide minerals in various pastel shades, as seen in Figure F26D. In some large oxide grains located at the edges of mottles (but otherwise in contact with the groundmass), these exsolution minerals appear to have been subject to further alteration and oxidation within the same thin section; in these instances, the crystals are more obviously gray, white, or pinkish gray in tone, and the crystals themselves having "ragged" or diffuse edges (Fig. F26D) within which internal reflec- tions are bright red. The presence of four different oxide minerals in those examples may indicate that the grain previously was a gridwork of two minerals, these being ilmenite and magnetite solid solutions, and that these in turn underwent exsolution upon further oxidation: the possible oxide phases are ferrirutile, rutile, titanohematite, and pseudobrookite, within the framework of titanomagnetite oxidation Stages C4-C7 of Haggerty (1991). The presence of pseudobrookite would indicate that the exsolution temperatures reached $585^{\circ} \mathrm{C}$ (Lindsley, 1965).

Pillow basalt almost never contains titanomagnetite modified by deuteric alteration. This is because titanomagnetite in pillow lavas is usually tiny because it forms at very high cooling rates and because deuteric alteration typically only occurs during slow cooling of fairly thick lava flows or dikes. In Hole U1349A these complex oxy-exsolution features are very common, and exsolution lamellae occur even in the finegrained rocks of Subunit IIIa (Fig. F27A, F27B) and in some very thin flow units interbedded with sedimentary rock. Additional exsolution and partial dissolution of titanomagnetite occurs in rock recovered $20 \mathrm{~m}$ deeper (Fig. F27C). Below this, at even deeper core intervals, skeletal titanomagnetite can have a remarkable array of exsolution features (Fig. F27D). In the deepest rocks of Subunit IVc (in Core 324U1349A-13R) titanomagnetite is extensively dissolved (Fig. F27E) and narrow residual ilmenite lamellae form most of the residual framework of the oxide minerals. Finally, in the rocks of Unit V, titanomagnetite has vanished completely, which is evidenced by the rocks having low magnetic susceptibility values (see "Physical properties").

\section{Development of hematite}

Importantly, the brick-red color of basalt of Unit IV results from the presence of abundant Fe oxyhydroxides and hematite in the groundmass and not from iddingsite in altered olivine. These oxide minerals are closely spaced and fairly well crystallized (Fig. F28A) and are composites of both minerals, with the hematite being the most reflective (Fig. F28B). It forms thin veinlets that trace across both olivine and spinel and ringlets around deep red Fe oxyhydroxide crystals that lie between plagioclases (Fig. F28C). These oxides partly replace clinopyroxene (Fig. F28D), patches of intersertal glassy material, and the exterior portions of original titanomagnetite (Fig. F28E).

\section{Vesicles and the consequences of magma mixing}

In many volcanic circumstances, rocks with up to $75 \%$ vesicles (Fig. F29) are most unusual. Primitive olivine tholeiite and picrite that erupt on spreading 
ridges are not known to be volatile rich (Dixon, 1995; Asimow et al., 2004). Therefore, in very shallow water, such a huge vesicle percentage is unlikely to have been generated by simple magmatic degassing (Fig. F19). Not even Hawaiian tholeiite, which is more enriched than MORB, produces such a highly vesicular product, either in subaerial or submarine lava flows. However, it seems that the primitive basaltic rocks of Hole U1349A were practically foam when they erupted.

However, not all rocks of Unit IV have high vesicle abundances; for instance, the rocks with clear evidence for internal lava flow magma mixing show bands of significantly reduced vesicularity. The least vesicular part of the thin section in Figure F30 is the fine-grained diagonal nonophimottled domain. This less vesicular domain may have been the hotter of two constituent magmas, or it might have had a slightly different viscosity, yet it crystallized at the same cooling rate to a finer grain size. A similar contact between two different lithologies traverses vertically for a portion of the core, as shown in a thin section scan (Fig. F31A). In this figure, the highly vesiculated magma type on the left is more crystalline, and its altered mafic minerals are gray-green, standing out against plagioclase. The vesicles are infilled calcite cement and amount to nearly $75 \%$ of that part of the thin section. The orange rock on the right is more finely crystalline and contains only $10 \%$ vesicles, whereas the zone of magma mingling between the two has very few vesicles. Examination of the orange material at higher magnification reveals a sharp change in its crystallinity with distance away from the region of mingling. At the contact, the rock is extremely fine grained and spherulitic (Fig. F31B) but becomes more crystalline away from this contact, with better-formed plagioclase and (now mostly altered) dendritic pyroxene (Fig. F31C, F31D). Dark spots in the orange material are altered olivine that has an interior network of trellised hematite (Fig. F31E). This likely resulted from hightemperature oxidative alteration of the olivine, first exsolving the low-Ti magnetite, effectively taking all the iron in the magmatic olivine and leaving almost pure forsterite between the trellis work. Further oxidation transformed the magnetite to hematite (Haggerty and Baker, 1967).

These textures show that the orange magma type, carrying many olivine phenocrysts, was likely hotter and then chilled or quenched against the coarser grained gray magma type. The temperature difference between the two magma types might have been as high as $100^{\circ} \mathrm{C}$. This magma mingling may have thus caused the host rock to "boil" along the contact with the higher temperature magma injection. De- pending on the (yet undetermined) scale of such a superheating process, the locally released volatiles may have coursed through the lavas, producing a magma froth. After mixing with seawater, high abundances of these released volatiles could represent a possible agent that caused the oxy-exsolution in titanomagnetite at high temperatures during the eruption process, as well as a second source of oxygen to produce the brownish red rocks in Unit IV.

\section{Flow breccia sequence (stratigraphic Unit V, lithologic Unit 32)}

Unit $\mathrm{V}$ consists of basaltic flow breccias that formed under water. A number of breccia fragments were quenched to glass, but this is now totally altered (Fig. F32). Nevertheless, phenocrysts and tabular plagioclases can still be distinguished from the noncrystalline surroundings. In larger clasts, textures change in a similar fashion to those at the margins of pillow lava (i.e., to zones of isolated and coalesced spherulites; Figs. F32B, F33B, F33C) and then to sheafs and bundles of acicular plagioclase in an altered darker microcrystalline matrix (Figs. F32C, F32D, F33D). All of this material is now completely replaced by clays. No titanomagnetite can be seen, although some very tiny black crystals (too small to render a good surface for polishing) lie within the thickness of the thin section and may be residual ilmenite or secondary low-Ti magnetite, the vestigial remnants of alteration of titanomagnetite and clinopyroxene.

The original rocks may not have been identical in composition. Thin Section 258 (Sample 324U1349A-16R-2, 7-14 cm) has a suggestion in its crystal morphologies of division into former plagioclaseclinopyroxene aggregates, perhaps mottles, that are surrounded by darker swaths of finer grained spherulitic material (Fig. F32D), whereas similar relict mottling is not evident in Thin Section 262 (Sample 324U1349A-16R-6, 71-73 cm; Fig. F33). Spinel also occurs in the altered glass of the latter thin section (Fig. F33A) and every other more crystalline portion of the rock (Fig. F33B-F33E). Hopper crystallites of altered olivine occur in spherulitic portions of the thin section (Fig. F32B), and a number of peculiar radiating circular sheafs of a fibrous mineral with moderately high birefringence (Fig. F32F) could be incipient bundles or rosettes of clinopyroxene.

Olivine phenocrysts probably are $\sim 5 \%$ of any thin section in Unit $\mathrm{V}$, but the olivine is invariably pseudomorphed by calcite (Fig. F34A) or clays and Fe oxyhydroxides (Fig. F34B). In the rocks of Unit V, hematite is all but gone as a secondary replacement in olivine (Fig. F34C-F34E). Only Cr spinel survived most of the alteration in Unit $\mathrm{V}$, although reticulate alteration and pitting does occur (Fig. F35A, F35B). 
The spinel is usually brown, but where unaltered and relatively thin it has a slightly greenish tint (Fig. F35C), suggesting a rather aluminous composition. Otherwise, the mineral occurs both in olivine phenocrysts and scattered through spherulitic groundmasses amid the acicular plagioclases and buttonlike pyroxene rosettes (Fig. F35D, F35E).

One thin section has a peculiar large vermicular $\mathrm{Cr}$ spinel phenocryst with an overall faceted outline (Fig. F36A) that must represent a type of skeletal crystal morphology. In reflected light, the spinel exhibits its usual triangular octahedral morphology (Fig. F36B). A similar crystal in basalt from the MidAtlantic Ridge was described by Eisenach (1979). The reflectivity is much lower than that of titanomagnetite, which in any case is absent from this particular thin section because of alteration. High magnification shows that the crystals are indeed brown with a greenish tint, like other spinel in Unit V, and not black, the color of titanomagnetite (Fig. F36C).

\section{Preliminary assessment}

The basalt in Hole U1349A is the most primitive rock recovered during Expedition 324. However, further revealing its primary igneous chemistry will require disentangling the profound effects of alteration seen in the rocks of stratigraphic Units IV and V. Aspects of its mineralogy, especially the compositions of pyroxenes and intergrown plagioclase in the ophimottled rock and of Cr spinel throughout, will aid in addressing this task. Perhaps the most pressing question involving Units IV and V concerns the formation of olivine-replacing hematite in the basalt matrix and the pervasive oxy-exsolution of most (if not all) of the titanomagnetite, which arguably occurred at temperatures of $\sim 600^{\circ} \mathrm{C}$. One possibility is that the basaltic magmas were initially oxidized and oxide minerals were transformed at high temperatures because of their encounter with juvenile and meteoric fluids accompanying the boiling associated with the magma injection and mixing. Afterward, alteration would have then taken a more usual course, becoming mainly an overprint produced by normal interaction with fluids modified from seawater during hydrothermal or low-temperature circulation. The dusky green color, the disappearance of titanomagnetite, and loss of the magnetic susceptibility signal in Unit $\mathrm{V}$ suggest that temperatures during this second-stage bulk alteration were still elevated. Chemical analyses indicate that the process of alteration significantly leached $\mathrm{K}_{2} \mathrm{O}$ and added $\mathrm{MgO}$ to these rocks, whereas the opposite effects occurred in the rocks of Unit IV.

\section{Alteration and metamorphic petrology \\ Alteration}

Basaltic rocks recovered from Hole U1349A have undergone extensive water-rock interactions under variable temperature conditions, resulting in complete replacement of glassy mesostasis and olivine phenocrysts. In the upper 218 mbsf (stratigraphic Unit IV; Sections 324-U1349A-7R-2 through 13R-4), both plagioclase and pyroxene are generally well preserved, whereas below this depth (bottom of Unit IV and Unit V; Sections 13R-5 through 16R-7), alteration is more pronounced with near complete replacement of pyroxene and almost complete replacement of plagioclase microliths. The overall alteration of the basaltic rocks ranges from high to complete (from $50 \%$ to $\sim 100 \%$ ) (Fig. F37), estimated visually using a binocular microscope on the archive half and an optical microscope on discrete thin section samples, without taking into account veins and vein halos.

Clay minerals are the predominant secondary minerals in Hole U1349A and were identified by optical microscopy and XRD patterns of whole rocks, vesicles, and veins. Saponite, nontronite, and montmorillonite are the main clay minerals replacing glassy mesostasis and primary phases (olivine, plagioclase, and pyroxene) and filling vesicles and veins. Calcite is the second most abundant secondary mineral in these basaltic rocks, both pervasively altering the rocks (glassy mesostasis and primary minerals) and filling vesicles, voids, and veins. Other alteration minerals present in Hole U1349A include hematite, Fe oxyhydroxides, and zeolite in the upper and middle parts of Unit IV (Sections 324-U1349A-7R-2 through 13R-4) and chlorite and rare serpentine at the bottom of Unit IV and in Unit V (Sections 13R-5 through 16R-7) (Fig. F37).

Alteration degree and mineralogy at Site U1349 will be compared with that of basaltic rocks recovered at previous sites at Shatsky Rise, Site U1346 on Shirshov Massif, and Site U1347 on Tamu Massif, with previously well studied portions of ocean crust (Alt, 1995, 2004) and basalts recovered from the Ontong Java Plateau (OJP) (ODP Leg 192; Mahoney, Fitton, Wallace, et al., 2001; Banerjee et al., 2004).

\section{Alteration description}

Based on alteration color and mineralogy, we identified two main types of pervasive alteration separated by a gradual transition zone. Alteration colors range 
from reddish brown at the top of the basaltic sequence in Hole U1349A to green toward the bottom. The distribution of alteration colors, alteration degree, and mineralogy are given in Figure F37 and 324ALT.XLS in LOGS in "Supplementary materials." Two main types of veins and three main types of vesicles were identified throughout the hole, with variations in mineral infilling vesicles depending on the alteration type.

\section{Red-brown alteration}

Red-brown alteration of basaltic rocks was only encountered in the upper portion of the basaltic sequence of Hole U1349A in Unit IV (from Section 324-U1349A-7R-2 to 12R-3) (Fig. F37). Overall alteration of the basalts ranges from $50 \%$ to $~ 100 \%$ based on petrographic observations of thin sections. Clay minerals are the predominant secondary minerals, extensively replacing groundmass and phenocrysts. One characteristic of this alteration is the replacement of olivine phenocrysts by iddingsite (e.g., Fig. F38) and the formation of hematite (Fig. F39). Iddingsite $\left(\mathrm{MgFe}_{2} \mathrm{Si}_{3} \mathrm{O}_{10} \cdot 4\left[\mathrm{H}_{2} \mathrm{O}\right]\right)$ is an olivine pseudomorph consisting of a mixture of clay minerals, Fe oxides (i.e., hematite), and ferrihydrides. Based on XRD spectra from whole-rock samples, the clay minerals forming iddingsite are mainly saponite $(\mathrm{Mg}$ smectite) and montmorillonite (Fig. F40). Plagioclase microliths are also significantly altered to brown clays and/or a K-rich phase. In fact, the high-K content of the basaltic rocks (see "Geochemistry") and the XRD spectra (Fig. F40) may suggest that plagioclase microliths have been replaced by sanidine; however, it was difficult to identify sanidine petrographically because of the fine-grained size of the plagioclase crystals. Titanomagnetites demonstrate exsolutions of magnetite and ilmenite observed in thin sections (Fig. F41). Glassy mesostasis is altered to a mixture of likely saponite, Fe oxyhydroxides, and hematite, giving a red-brown color to the rocks (Fig. F39). The only phase that remains relatively unaffected by alteration and fluid-rock interaction is clinopyroxene (Fig. F42).

In addition, nine intervals interpreted to be subaerially weathered flow tops have been identified within Unit IV (see "Igneous petrology") (Fig. F43A). These weathered horizons demonstrate near-complete alteration of primary magmatic minerals to dark reddish brown fine-grained clay minerals, Fe hydroxides, and Fe oxides. An XRD spectrum from one weathered horizon (Sample 324-U1349A-10R-1, 10$13 \mathrm{~cm}$ ) (Fig. F43B) indicates that this rock is likely composed predominantly of hematite $\left(\mathrm{Fe}_{2} \mathrm{O}_{3}\right)$, goethite $(\mathrm{FeO}[\mathrm{OH}])$, sanidine, montmorillonite, and hal- loysite $\left(\mathrm{Al}_{2} \mathrm{Si}_{2} \mathrm{O}_{5}[\mathrm{OH}]_{4} \cdot 2 \mathrm{H}_{2} \mathrm{O}\right)$, consistent with subaerial weathering.

\section{Transition zone}

A gradual brown to green alteration zone (205-224 mbsf) from the base of Unit IV (Section 324-U1349A12R-4) to the upper portion of Unit V (Section 14R3 ), forms a transition between the two main alteration types (red-brown alteration of the upper part of the hole and green alteration at the bottom) (Fig. F37). Overall alteration of the basalts in this transitional zone ranges from $50 \%$ to $~ 100 \%$ based on petrographic observations of thin sections. Secondary minerals are still predominantly clay minerals replacing the glassy mesostasis and the primary phases. Olivine phenocrysts are pseudomorphed and predominantly replaced by iddingsite, saponite, and calcite (e.g., Thin Section 234; Sample 324-U1349A12R-2, 111-113 cm) (Fig. F44). Clinopyroxene shows a higher degree of alteration in this transition zone and is replaced to various extents by brown clays. Identification of clinopyroxenes in thin sections becomes difficult, suggesting partial replacement between 205 and 216 mbsf and almost complete replacement below 216 mbsf (from Thin Section 242 to the bottom) (Fig. F37). Plagioclase microliths are also extensively altered and replaced by brown clays. Within this entire alteration zone, significant hematite is present in thin sections from Unit IV but is not present in thin sections of the breccia clasts of upper portion of Unit V. Similar to the red-brown alteration, titanomagnetite crystals show primary igneous morphology with exsolutions of magnetite and ilmenite.

In this alteration transition zone, higher temperature minerals replace groundmass glass or fill veins. Zeolite (identified as probable stilbite) was observed replacing glassy mesostasis and filling vesicles and voids (e.g., Thin Section 237; Sample 324-U1349A13R-1, 29-32 cm). Chlorite veins were also observed as a late stage of fluid circulation in Thin Section 235 (Sample 324-U1349A-12R-3, 32-34 cm) (Fig. F45). In this sample, the crosscutting relationships allow us to roughly reconstruct the alteration history of this sample: (1) alteration of olivine to iddingsite and formation of clay minerals \pm Fe oxyhydroxides on the walls of the vesicle, (2) infilling of vesicles with calcite, (3) chlorite vein, and (4) calcite veins.

\section{Green alteration}

Green alteration is only found from 224 mbsf to the bottom of the hole, affecting the volcanic breccia of Unit V (Fig. F37). In this zone, the basaltic clasts are highly to completely altered to green clays, with 
overall alteration degree from $70 \%$ to $~ 100 \%$ based on petrographic observations of thin sections. Primary minerals and glassy mesostasis are predominantly replaced by secondary clays (saponite, montmorillonite, and nontronite based on XRD patterns). Olivine phenocrysts are mainly altered to saponite and calcite, with minor replacement by serpentine along the fractures of the mineral (Fig. F46). Plagioclase microliths and pyroxene are extensively altered and replaced by brown clays. Hematite is no longer present in thin section and titanomagnetite is extensively altered to completely absent in some thin sections. This is consistent with a change in magnetic susceptibility (see "Paleomagnetism" and "Physical properties"). The highly altered breccia clasts are cemented by variable proportions of calcite and light green clays. The light green clays show floret morphology (Fig. F47) and are likely saponite and nontronite, as indicated by XRD spectra. Commonly, Fe oxyhydroxides are observed associated with the light green clays and calcite cement. In addition, XRD spectra from the breccia cement show peaks for calcite, nontronite, montmorillonite, and bannisterite. Bannisterite (or ganophyllite; $[\mathrm{K}, \mathrm{Ca}]_{0.5}[\mathrm{Mn}, \mathrm{Fe}, \mathrm{Zn}]_{4}\left[\mathrm{Si}, \mathrm{Al}_{7} \mathrm{O}_{14}[\mathrm{OH}]_{8}\right)$ is a mineral that is likely formed from metamorphism of Mn deposits.

\section{Veins}

Veins are found throughout the entire basaltic section in Hole U1349A. In the basalt flow breccia of Unit V, distinction between veins and cement infilling clasts was difficult and veins were only recorded when cutting the basaltic clasts (Cores 324-U1349A$14 \mathrm{R}$ to $15 \mathrm{R}$ ). For this reason, no veins were recorded in Core 324-U1349A-16R. A total of 324 veins and vein networks were recorded in the $\sim 49 \mathrm{~m}$ of basement rock recovered from Hole U1349A (Fig. F37), giving an average of 6.6 veins $/ \mathrm{m}$.

Two main types of veins were identified in Hole U1349A, irrespective of the alteration type: (1) calcite veins and (2) calcite, green/brown clay, and Fe oxyhydroxide veins. In addition, in the upper 186 mbsf zeolite is rarely associated with calcite in veins (Fig. F37).

Calcite veins show two main morphologies, crystalline blocky calcite and cross-fiber calcite. The crossfiber calcite veins commonly cut the crystalline calcite veins (Fig. F48A), suggesting multiple stages of fluid circulation. The calcite veins result from symmetrical infilling of open cracks with minor or no replacement of the wall rock. Zeolites are a minor component in crystalline calcite veins in Cores 324U1349A-8R through 10R. The calcite, green/brown clay, and Fe oxyhydroxide veins show highly vari- able proportions in calcite and clay minerals. Most veins have $<10 \%$ clay, but occasionally they contain $>70 \%$ clay minerals (e.g., Thin Section 229; Sample 324-U1349A-11R-4, 88-93 cm). The green-brown clays and Fe oxyhydroxides are typically intergrown, suggesting simultaneous formation and crystallization, with a late stage calcite cement. The calcite, green/brown clay, and Fe oxyhydroxide veins commonly cut calcite veins (Fig. F48B) and commonly show halos as wide as $1 \mathrm{~cm}$ of near complete alteration (Fig. F48D). In the red-brown alteration of the upper part of the hole, saponite is the dominant halo mineral. In the alteration transition zone and the green alteration zone, very pale fine-grained green chlorite is the dominant halo mineral (Fig. F45). In the red-brown alteration and transition alteration zone, the clay minerals in the veins include saponite, nontronite, and celadonite (Fig. F48C). In the green alteration, the clays are pale green with floret morphology identical to the smectite clays (likely saponite) in the breccia cement (Fig. F47). In the breccia unit, some oxidation variations have occurred that lead to juxtaposition of vein material with green clays and vein material with oxidized orange clays (Fig. F48D).

\section{Vesicles}

Basaltic rocks in Hole U1349A are poorly to highly vesicular, the latter especially in the upper part of the hole. Three main types of minerals filling vesicles have been identified in Hole U1349A, calcite with minor zeolite, saponite, and zeolite. Calcite vesicles are observed in the entire section and show two main textures, blocky and/or fibrous (Fig. F49A). In some samples (e.g., Thin Section 215; Sample 324U1349A-9R-1, 36-40 cm), tabular zeolite minerals are observed at the rim of the calcite vesicle (Fig. F49A, F49B). In contrast, zeolite- and saponite-filled vesicles are restricted to some intervals and units. Saponite-filled vesicles are only present in the basalt flow breccia of Unit V (Fig. F49C), whereas zeolitefilled vesicles are restricted to the basaltic rocks of the transition alteration zone (Fig. F49D). In addition, basalts from the upper part of the hole (i.e., Core 324-U1349A-7R) have vesicles that have been partially filled with different successive layers of finegrained micrite, clays, and Fe oxyhydroxides (e.g., Thin Section 206; Sample 324-U1349A-7R-1, 112-115 $\mathrm{cm})$. In general the vesicles show a sharp horizontal contact with crystalline calcite and are interpreted as geopetal vesicles.

\section{Interpretations of alteration}

Basaltic rocks in Hole U1349A have undergone extensive fluid-rock interaction with variations in re- 
dox and temperature conditions of the circulating fluids. The predominance of clay minerals with iddingsite, calcite, and hematite in the upper and middle part of Unit IV (165-205 mbsf) suggests alteration under relatively oxidizing and relatively low temperature conditions. Iddingsite is an olivine pseudomorph consisting of a mixture of clay minerals and Fe oxides (i.e., hematite) and is commonly observed as an alteration product of olivine in extrusive or subvolcanic igneous rocks formed by injection of magma near or at the surface. Evidence for subaerial exposure, and possibly extrusion of Unit IV basalts, comes from the presence of subaerially weathered horizons within Unit IV, geopetal vesicles, and magnetite-ilmenite exsolutions after titanomagnetite. Such exsolution is commonly observed in subaerially erupted basalt flows in which deuteric oxidation of titanomagnetite occurs (Dunlop and Özdemir, 1997). The highly oxidized nature of the upper and middle lavas of Unit IV suggests subaerial tropical weathering processes (Widdowson, 2007), which is consistent with Shatsky Rise's equatorial paleolatitude. Furthermore, the high $\mathrm{K}$ content of basalts from Unit IV (see "Geochemistry") and the likely presence of sanidine indicate that once the lavas were submerged, more typical oceanic alteration occurred with interaction of the lavas with low-temperature circulating seawater leading to $\mathrm{K}$ uptake into the basalts (Alt 1995, 2004).

Secondary mineral assemblages change in the transition alteration zone and toward the bottom of the hole, reflecting different temperature and redox conditions of alteration. The replacement of olivine by saponite and calcite, the occurrences of chlorite veins and zeolite replacing glassy mesostasis and filling vesicles, and the persistence of hematite suggest higher temperature and less oxidizing conditions than the upper part of the hole. In the basalt flow breccia (Unit V), the replacement of olivine by saponite and minor serpentine, the lack of hematite and the vesicles filled by saponite, and the possible occurrence of metamorphosed Mn deposits (e.g., bannisterite) suggest more reducing conditions and likely higher temperature conditions than in the basaltic rocks above.

The majority of the highly altered basaltic rocks recovered from Hole U1349A may be compared with typical alteration occurring in the oceanic crust (Alt, $1995,2004)$. The red-brown alteration zone affecting the basalts in the upper part of Hole U1349A is similar to the low-temperature oxidative alteration observed in the upper portion of the oceanic crust, with the formation of clay minerals (e.g., nontronite and celadonite) and the uptake of alkalis from seawater (for temperature $<70^{\circ} \mathrm{C}$ ). However, hematite formation does not occur in common alteration of MORBs and is more typical of tropically weathered basalts (Widdowson, 2007). The transition alteration zone shows similar alteration conditions and mineralogy to that observed deeper in the oceanic crust, where an increase in the temperature of circulating seawater-derived fluids $\left(>150^{\circ} \mathrm{C}\right)$ and more reducing conditions allows formation of higher temperature minerals, such as chlorite and zeolite. Therefore, the lavas in Unit IV record two stages of alteration: first, subaerial alteration immediately after extrusion, and second, seawater alteration upon submergence of the lavas.

Alteration in Hole U1349A is characterized by variable degrees and conditions of fluid-rock interaction, from oxidative at the top to reducing conditions at the bottom, and consequently differs from the suboxic and $\mathrm{CO}_{2}$-rich alteration observed at Site U1346, the low degree of alteration at Site U1347, and the dark gray alteration observed for the basalts of the OJP (Mahoney, Fitton, Wallace, et al., 2001; Banerjee et al., 2004).

\section{Structural geology}

Cores recovered from Hole U1349A contain volcaniclastic sedimentation structures in the upper part of the drilled section, structures of magmatic origin and intensive alteration of the igneous basement in the lower part, and deformation through the entire set of cores. Structures described here are solely within the basalt complex between 165.06 mbsf in Core 324-U1349A-7R and 251.30 mbsf in Core 16R and exhibit wholly brittle and obvious magmatic flow structures. The main structural features are represented by two types of magmatic flow structures, subaerial and submarine sheet flows. The details of these structures are characterized by distribution patterns of amygdules (or vesicles), veins, and texture variation. All of these igneous structures include syn- to late magmatic structures that are linked to flow, cooling, and solidification of lava and postmagmatic structures that are associated with the deformation of basalt.

In the following sections, the characteristics of the major three types of structures are described, followed by a discussion of distribution, orientations, and relationships between structures and a short summary. Important observations and interpretations include preferred orientations, crosscutting, and contact relationships of planar and subplanar structures and variation in structural morphology such as pattern, size, shape (roundness and sphericity), and vesicles (vesicularity). These are evi- 
dence for close linkages between extrusive processes, fluid flow, brittle deformation, and paleostress field.

\section{Magmatic flow structures}

Magmatic flow structures exhibit evidence of particle rotation or plastic strain imposed by the flow of viscous magma and provide clues to movement plane and direction (Davis, 1984; Passchier and Trouw, 1996). Both subaerial and submarine sheet flow structures are well developed in Hole U1349A and are described as follows.

\section{Subaerial sheet flow structure}

In the subaerial sheet flow, basaltic lava flows often form two main structural types, one smooth surfaced (pahoehoe) and the other rough surfaced (a'a), which are fundamentally different in their structures and flow dynamics (Walker, 1993). In this hole, a'a structure is not confirmed. The top pahoehoe surface in most sheet flows can be identified.

The subaerial sheet flow structure in this hole is developed in the upper part (Sections 324-U1349A-7R1 through 13R-4) of the igneous basement. Reddish brown lavas showing high oxidation may indicate that these were subaerial eruptions. Some intercalated oolitic limestones, however, suggest that some of the lavas erupted in the shallow-marine environment (interval 324-U1349A-9R-1, 1-13 cm) (see "Sedimentology"). The volcaniclastic clasts above the igneous basement (above Section 324-U1349A7R-1) are subrounded, implying the clasts were transported in an epiclastic origin or very shallow marine environment. Other indicators of subaerial environment in Hole U1349A are many hollow vesicles or spongy vesicles and no clear chilled margin in the upper part of the igneous basement. Based on Walker's criteria (Walker, 1993), these indicators provide evidence for eruption in a subaerial environment.

A sheet flow is generally composed of three parts, lava upper crust, lava core, and basal zone (Keszthelyi et al., 1999). The distinctive and typical structure of at least five sheet flows in Hole U1349A is displayed in Sections 324-U1349A-9R-1 through 10R-5 (Fig. F50).

The lava upper crust (A and B in Fig. F50) is characterized by relatively high vesicularity, hypocrystalline textures, and presence of a horizontal vesicle zone. Vesicularity decreases from top to bottom in the upper crust. Although many vesicles are filled with calcite, forming amygdules, several horizontal vesicle zones are not completely filled in Hole U1349A. The size distribution and shape of the vesicles in the upper crust show that the horizontal zones of vesicles can be interpreted to form when upward-migrating gas bubbles are trapped against the downward-growing solidification front of the upper crust of the flow. In this part of the sheet flow, no joints develop. By the top of the lava upper crust, we also observed some ropy folds in the lava core at interval 324-U1349A11R-3, 102-120 cm (Fig. F51).

In the lava core ( $\mathrm{C}$ in Fig. F50), vesicles are scarce, which is generally characterized by $<2 \%$ vesicles, pipe vesicles, regular jointing, fine-grained groundmass, holocrystalline texture, and massive structure. Sometimes we also find typical pipe vesicles in the lava core, such as in interval 324U1349A-13R-4, 119-126 cm. They are subvertical, $\sim 0.5-1.0 \mathrm{~cm}$ in diameter, and filled with calcite in Hole U1349A.

The basal zone (D in Fig. F50) is usually $0.5-1 \mathrm{~m}$ thick, but it is often incompletely recovered in Cores 324-U1349A-7R through 13R. It is characterized by slight vesicularity and rare joints and subvertical or stretched pipe vesicles at the base. The basal zone usually comprises much less than $10 \%$ of the overall thickness of the sheet flow.

\section{Submarine sheet flow structure}

The submarine sheet flow structure is developed in the lower part of the igneous basement. The principal difference between underwater and subaerial volcanism is that explosive volcanism is suppressed under deep water (Walker, 1993). Submarine pillow lavas are remarkably similar to subaerial pahoehoe but are, on average, less vesicular. Small rounded flow units (pillow lavas) are important charateristics of underwater lava flows and are distingushed from subaerial flow units (e.g., pahoehoe) by continuous glassy rims (see intervals 324-U1349A-16R-6, 72-82 cm, and 16R-7, 1-10 cm) (Fig. F52). Other indicators of submarine lava flow in Hole U1349A include hyaloclastite and autobreccia (Fig. F52).

\section{Veins}

Fractures occur at discrete breaks in a rock mass in which cohesion was lost. In Hole U1349A, a considerable thickness $(>0.1 \mathrm{~mm})$ of filling material occupies the region between the fracture walls. There are a large number of veins in Hole U1349A. Vein widths are generally $<10 \mathrm{~mm}$ (most are $\sim 0.1$ or $\sim 2$ $\mathrm{mm}$ wide). The density of veins is at least 4 veins $/ \mathrm{m}$. In general, the population of veins in the lava cores is greater than that in the upper crust and basal zones. Sometimes we observe a vein ribbon composed of $>20$ veins with $1-3 \mathrm{~mm}$ vein spacing, 
for example, at intervals 324-U1349A-10R-5, 76-79 $\mathrm{cm}$, and 13R-5, 123-129 cm.

Vein texture is complex in Hole U1349A and characterized by cross-fibers composed of spherulitic or needlelike zeolites growing perpendicular to the vein wall (Thin Section 260; Sample 324-U1349A16R-6, 7-12 cm) (Fig. F53A, F53B). The second important vein texture is polycrystalline, mainly displayed by calcite (Thin Section 254; Sample 324U1349A-15R-4, 104-110 cm) (Fig. F53C). Sometimes we observe massive texture filled with glassy material and intravenous texture filled with disorderedly aligned calcite or zeolite (Thin Section 249; Sample 324-U1349A-14R-5, 53-54 cm) (Fig. F53D). Most of the veins accompany a thin alteration halo.

Vein geometry includes vein array and vein shape. Most veins are straight or irregular in shape. Sigmoidal-shaped veins are only seen in Section 324U1349A-10R-4. Various characteristics of vein morphology are observed, including all vein types (conjugate, en echelon, parallel, branched, network, anastomosing, and ribbon) (Fig. F54). Generally, conjugate and en echelon veins are closely associated with shear or extensional joints at this site (e.g., interval 324-U1349A-9R-1, 126-139 cm) (Fig. F54B). In some samples, veins have splays and intersect other veins with Y-shaped (Fig. F54C, F54D) and A-shaped morphologies. These intersections can be complex, with changes in mineralogy along the length of the vein. Furthermore, many veins that apparently merge in hand samples have crosscutting relationships when observed in thin sections (Fig. F55).

Crosscutting relationships can also be found as displacements at vein intersections, even under the microscope, showing that jointing occurred in at least three generations resulting from a postmagmatic multiphase process. Furthermore, the horizontal or subhorizontal veins generally cut the others, for example in intervals 324-U1349A-10R-2, 25-38 cm, and 68-85 cm (Fig. F55A, F55B) and in Thin Section 221 (Sample 324-U1349A-10R-3, 43-48 cm) (Fig. F55C, F55D).

Syntaxial growth in vein kinematics is very common in the hole; antiaxial and ataxial growths are rare (Passchier and Trouw, 1996). Calcite-rich veins commonly show polycrystalline fabrics and partly syntaxial or cross-fiber fabrics. Zeolites in the veins are dominated by syntaxial growth, sometimes displaying a polycrystalline texture (Fig. F53A, F53B).

Many veins, except those that are very thin or with well-defined walls, accompany halos in Hole
U1349A. The color of the alteration halos reflects secondary mineral contents. Vein-filling minerals change from calcite, zeolite, and nontronite to pyrite from early to late based on their microscopic relations in veins in Hole U1349A.

Dips of veins in the upper cores (324-U1349A-7R through 12R) become gradually steeper downhole. Dips of veins in the lower cores (324-U1349A-13R through 16R) are shallow again in the upper part of that section but gradually steepen downward (Fig. F56).

\section{Breccias}

Breccias are dominant below Core 324-U1349A-13R and show a dramatic change in magnetic susceptibility values (see "Physical properties") and color from reddish brown above interval 324-U1349A-13R-4, 1$96 \mathrm{~cm}$ (Fig. F57A), to greenish gray below this interval. A large change in structure occurs at interval 324-U1349A-13R-4, 1-96 cm, which is a reddish brown breccia zone that also acts as a boundary for other properties in the hole. Below this boundary, major volcanic autobreccias are characterized by a basalt clast-supported 20\%-60\% calcite matrix (Fig. F57B, F57C). This boundary is obviously related to hydraulic brecciation or hyaloclastite genesis. The clasts are subirregular to subrounded, with some zeolites growing perpendicular to the margins viewed under the microscope (Thin Section 246; Sample 324-U1349A14R-4, 50-56 cm, and Thin Section 249; Sample 324U1349A-15R-4, 104-110 cm) (Fig. F57D).

\section{Geochemistry}

\section{Major element oxide and trace element analyses}

We analyzed eight samples of vesicular lava from stratigraphic Unit IV and five samples of autobreccia from stratigraphic Unit V in Hole U1349A for concentrations of major element oxides and several trace elements (Table T6) by ICP-AES (see "Geochemistry" in the "Methods" chapter for information on analytical procedures, instrumentation, and data quality). All of the samples were highly to completely altered (see "Alteration and metamorphic petrology"). Two splits were taken from Sample 324U1349A-11R-5 (Piece 1A, 12-15 cm), which is an example of the mingling of two visually distinct types of lava observed in Unit IV (see "Structural geology"); one of the splits was from a zone of highly vesicular foamy lava and the other was from an immediately adjacent, red (oxidized), and much less vesicular zone. 
Variation in total weight percentages for the major element oxides is somewhat smaller than at Sites U1346-U1348, but still significant (98.28-103.32 $\mathrm{wt} \%)$, and we again normalized the raw major element values to $100 \mathrm{wt} \%$ totals. The normalized data are presented below the measured values in Table T6 and are used in the figures and in the discussion below.

Weight loss on ignition (LOI) is high in all samples, consistent with the extensive levels of alteration observed throughout the basement section at Site U1349. LOI values range from 10.03 to $34.76 \mathrm{wt} \%$ in samples from above 200 mbsf (within Unit IV), with the exception of Sample 324-U1349A-9R-2 (Piece 11, 93-95 cm), which has only $4.63 \mathrm{wt} \%$ LOI. The highly vesicular (foamy lava) split of Unit IV Sample 324-U1349A-11R-5 (Piece 1A, 12-15 cm) yielded the $34.76 \mathrm{wt} \%$ value. This split is dominated by calcium carbonate, as evidenced by its very high $\mathrm{CaO}(65.97 \mathrm{wt} \%)$ and low $\mathrm{SiO}_{2}(15.37 \mathrm{wt} \%)$ contents, and we do not discuss it further. The split from the adjacent reddish, less vesicular zone has lower but still very high, LOI (14.47 wt\%) and CaO (14.77 wt $\%)$. Three other samples from Unit IV contain significant amounts of $\mathrm{CaCO}_{3}$, as reflected in their high $\mathrm{CaO}(19.13-22.79 \mathrm{wt} \%)$ and $\mathrm{CaO} / \mathrm{Al}_{2} \mathrm{O}_{3}(1.14-1.37)$ values. Despite the intense alteration in the lower part of the basement section (see "Alteration and metamorphic petrology"), samples from below 200 mbsf (Unit V and the lower part of Unit IV; Sections 324-U1349A-12R-3 through 16R-6) yielded lower LOI values, from 2.37 to $6.51 \mathrm{wt} \%$, except for Sample 324-U1349A-14R-1 (Piece 9, 38-42 cm) with $10.65 \mathrm{wt} \%$.

Data for the four lowermost samples from Unit V lie in the field of tholeiitic basalt in a total alkalis versus silica diagram (Fig. F58A); these samples have four of the five lowest LOI values measured, between 2.37 and $4.99 \mathrm{wt} \%$. Samples from shallower portions of the hole exhibit more alkalic, lower $\mathrm{SiO}_{2}$ compositions. As at Site U1346 (see "Geochemistry" in the "Site U1346" chapter), this behavior appears to be a result of alteration, for $\mathrm{SiO}_{2}$ shows a negative trend with LOI and a rough positive trend with $\mathrm{K}_{2} \mathrm{O}$ content (Fig. F58B). In contrast, $\mathrm{Na}_{2} \mathrm{O}$ defines only a weak negative trend with LOI; therefore, as at Site $\mathrm{U} 1346, \mathrm{~K}_{2} \mathrm{O}$ is largely responsible for the increase in total alkali content with increasing LOI. The highest $\mathrm{K}_{2} \mathrm{O}$ value, $5.85 \mathrm{wt} \%$, is reached in the reddish split of Sample 324-U1349A-11R-5 (Piece 1A, 12-15 cm), which has an LOI of $14.47 \mathrm{wt} \%$. Increases in concentration with increasing LOI are also seen for $\mathrm{CaO}$, $\mathrm{P}_{2} \mathrm{O}_{5}, \mathrm{Sr}, \mathrm{Ba}$, and $\mathrm{Y}$, whereas $\mathrm{MgO}$ and $\mathrm{Cu}$ generally decrease with increasing LOI.
Contents of $\mathrm{K}_{2} \mathrm{O}$ in the three lowermost samples from Unit $\mathrm{V}$ are all very low $(\leq 0.02 \mathrm{wt} \%)$. The LOI values of these samples (2.37-4.99 $\mathrm{wt} \%)$, although small relative to values for Site U1349 overall, are nevertheless very large compared to LOI values for unaltered basalts. Given the very thorough but nonoxidative character of the alteration in Unit V (see "Alteration and metamorphic petrology"), we infer that these three samples have lost some potassium. Two of these samples and another sample from the lower part of Unit $\mathrm{V}$ also appear to have lost phosphorus, as they have very low $\mathrm{P}_{2} \mathrm{O}_{5}$ values $(\leq 0.01 \mathrm{wt} \%$; see Table T6).

$\mathrm{Mg} \#$ ranges widely at Site U1349 $\left(\mathrm{Mg \#}=100 \times \mathrm{Mg}^{2+} /\right.$ $\left.\left[\mathrm{Mg}^{2+}+\mathrm{Fe}^{2+}\right]\right)$, assuming that $\left.\mathrm{Fe}_{2} \mathrm{O}_{3} / \mathrm{FeO}=0.15\right)$. The

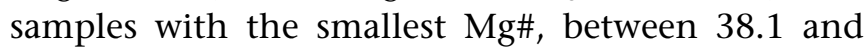
49.3 , are those with the greatest LOI $(\geq 10.03 \mathrm{wt} \%)$, which is consistent with variable reduction of $\mathrm{MgO}$ content during alteration of these rocks. In contrast, the samples with LOI $\leq 6.51 \mathrm{wt} \%$ have distinctly larger Mg\#, from 60.6 to 76.2; three of the Unit V autobreccia samples have values $>70$. As with the lower $\mathrm{Mg} \#$ basalts, alteration probably modified $\mathrm{Mg \#}$ in these samples. However, the highest Mg\# values are likely to also reflect accumulation of olivine crystals (and perhaps clinopyroxene), consistent with the relatively abundant pseudomorphs after olivine (and, where not altered to the point of being unidentifiable, clinopyroxene) observed in thin section (see "Igneous petrology" and "Alteration and metamorphic petrology").

Titanium and $\mathrm{Zr}$ are two of the more alteration-resistant elements in mafic rocks (e.g., Humphris and Thompson, 1978) and are incompatible in olivine and clinopyroxene (e.g., Salters and Longhi, 1999). In contrast to $\mathrm{Mg \# ,} \mathrm{TiO}_{2}$ variation is small at Site U1349, between 0.88 and 1.18 wt\% (Fig. F59A). These values are lower than observed for lavas of the other Expedition 324 sites or Leg 198 Site 1213. Zirconium concentrations are correspondingly low, between 44 and 55 ppm. In Figure F59B, the combined $\mathrm{Zr}-\mathrm{TiO}_{2}$ data form a small cluster at the lower end of the ocean-ridge basalt array and overlapping the Ontong Java field. Thus, the Site U1349 basalts appear to represent more primitive (less evolved) compositions than yet found elsewhere on Shatsky Rise. At least in terms of $\mathrm{TiO}_{2}$ and $\mathrm{Zr}$, they are similar to primitive ocean-ridge basalts and have only slightly higher concentrations than the most primitive basalts recovered from the OJP (the Kroenke basalts; Mahoney, Fitton, Wallace, et al., 2001; Fitton and Godard, 2004). Strontium and Y contents, despite being affected variably by alteration, are also low among the lower LOI Site U1349 samples (50-94 and 
9-26 ppm, respectively), again comparable to values in primitive ocean-ridge basalts.

Results for $\mathrm{Cr}$ and $\mathrm{Ni}$ are likewise consistent with relatively primitive magmatic compositions in that concentrations of both elements are high for basalt $(\mathrm{Cr}=338-607$ ppm; $\mathrm{Ni}=124-350 \mathrm{ppm})$ (Fig. F59C, F59D). However, the data must be interpreted cautiously, as the severe alteration at Site U1349 has probably affected concentrations of both elements to some extent, particularly Ni (cf. Site U1346 Ni data in the figure). Equally important, $\mathrm{Ni}$ and $\mathrm{Cr}$ are compatible in mafic phases and in chromian spinel, present as inclusions in olivine (see "Igneous petrology") (e.g., Bougault and Hekinian, 1974; Leeman and Scheidegger, 1977; Skulski et al., 1994; Righter et al., 2006). Accumulation of these minerals thus raises bulk rock $\mathrm{Ni}$ and $\mathrm{Cr}$ concentrations above those in the melt phase.

Besides olivine accumulation, possible evidence for clinopyroxene accumulation in some Site U1349 basalts is provided by Sc, which tends to be a compatible element in clinopyroxene but incompatible in other common basaltic minerals (e.g., Bacon and Druitt, 1988). Variation in Sc is small (44-56 ppm), but concentrations range to slightly higher values than found for most ocean-ridge or Ontong Java basalts at similar $\mathrm{TiO}_{2}$ levels (Fig. F59E). If this feature is a pre-alteration characteristic of the lavas, it could be a signature of clinopyroxene accumulation.

In summary, seeing through the chemical effects of severe alteration and crystal accumulation is difficult, but the Site U1349 basalts appear to represent significantly less differentiated tholeiitic magmas than any of the basalts recovered at the previously drilled Expedition 324 sites or Site 1213.

\section{Physical properties}

Volcanicalstic sediments and basalts in Hole U1349A were characterized for physical properties as described in "Physical properties" in the "Methods" chapter. Core sections with continuous intervals longer than $8 \mathrm{~cm}$ were run through the Whole-Round Multisensor Logger for measurement of gamma ray attenuation (GRA) density and magnetic susceptibility. Data from whole-round measurements were filtered to remove data associated with gaps and small pieces as described in "Physical properties" in the "Methods" chapter. Sections longer then $50 \mathrm{~cm}$ were measured with the Natural Gamma Radiation Logger. Thirty-two discrete, oriented cubic samples were cut from the working half of the cores for measurement of moisture and density (MAD) properties as well as compressional ( $P$-wave) velocities in three directions.

\section{Whole-Round Multisensor Logger measurements}

\section{Magnetic susceptibility}

Results of whole-round magnetic susceptibility measurements are shown in Figure F60. Distinctive magnetic susceptibility signatures are observed within all of the Hole U1349A stratigraphic units (see "Sedimentology"). Unit II and Subunit IIIa are claystonesandstones with a large proportion of volcaniclastics. These units are characterized by magnetic susceptibilities of $<1000 \times 10^{-5}$ SI. Subunit IIIb consists of volcaniclastic conglomerate. Section 324-U1349A7R-1 of the conglomerate contains the highest magnetic susceptibility readings measured during Expedition 324 . The signal of almost $4000 \times 10^{-5}$ SI corresponds to a large basaltic clast, which, upon thin section investigation, was found to contain abundant groundmass magnetite (see "Igneous petrology").

The top of the basaltic basement was encountered in Section 324-U1349A-7R-1 at $96 \mathrm{~cm}$ (165.1 mbsf), denoting the top of the vesicular basalts making up Unit IV. The upper $26 \mathrm{~m}$ of this unit (from Section 7R-1 to 10R-5) is characterized by low magnetic susceptibility. This interval has an overall red appearance and contains abundant hematite (see "Igneous petrology" and "Paleomagnetism"). Hematite, although magnetic, has less susceptibility than magnetite, and this may explain the lower readings measured in this interval. From Core 324-U1349A-11R to $13 \mathrm{R}$, magnetic susceptibility increases (average = $\left.1000 \times 10^{-5} \mathrm{SI}\right)$, reaching values $>2000 \times 10^{-5} \mathrm{SI}$. Unit $\mathrm{V}$ commences at $221.7 \mathrm{mbsf}$ and is composed of autobrecciated basalts. The brecciated material composing Cores 324-U1349A-14R through 16R has very low magnetic susceptibility readings (average $=105 \times$ $\left.10^{-5} \mathrm{SI}\right)$.

\section{Gamma ray attenuation bulk density}

The results for GRA bulk density measurements from Hole U1349A are shown in Figure F60. Volcaniclastic sandstones, claystones, and lapillistones of Unit II and Subunit IIIa have low GRA densities of $\sim 1.8-2.0$ $\mathrm{g} / \mathrm{cm}^{3}$. The rest of the hole has GRA densities $>2.0$ $\mathrm{g} / \mathrm{cm}^{3}$, remaining fairly uniform with an average of $2.2 \mathrm{~g} / \mathrm{cm}^{3}$ in igneous material. The autobrecciated basalts of Unit V show increased variation in GRA density. This is not surprising, given the heterogeneous clast type and distribution observed in this unit (see "Sedimentology" and "Igneous petrology"). 


\section{Natural Gamma Ray Logger}

Measurements of natural gamma radiation (NGR) are shown in Figure F60. Counts per second range from 1 cps to almost $40 \mathrm{cps}$ throughout the hole, with an average of $13.8 \pm 12.5 \mathrm{cps}(2 \sigma)$. The range of counts per second is slightly lower but still comparable to the altered basalts of Hole U1346A ( 22 cps). Gamma spectra from Hole U1349A indicate that counts dominantly result from the ${ }^{40} \mathrm{~K}$ decay chain. Excursions to high NGR counts occur in sedimentary Unit II and Subunit IIIa. In general, the vesicular basalts of Unit VI and the upper part of brecciated basalts in Unit $\mathrm{V}$ (above $225 \mathrm{mbsf}$ ) have higher (10-15 cps) counts than the lower autobrecciated basalts of Unit V (5-10 cps). The lower counts found in the middle and lower sections of Unit $\mathrm{V}$ (below 225 mbsf) are consistent with low $\mathrm{K}_{2} \mathrm{O}$ values, some of which were below the detection limit of ICP measurements (see "Geochemistry").

\section{Moisture and density}

Summaries of bulk density, dry density, grain density, void ratio, water content, and porosity measurements on discrete samples are listed in Table T7. Densities and porosities are shown in Figure F61 and display a good negative correlation. Bulk density ranges from 2.06 to $2.34 \mathrm{~g} / \mathrm{cm}^{3}$ in Unit II and Subunit IIIa. Density increases in the igneous material of Units IV and $\mathrm{V}$ to values between 2.16 and $2.96 \mathrm{~g} / \mathrm{cm}^{3}$, averaging $2.63 \pm 0.34 \mathrm{~g} / \mathrm{cm}^{3}(2 \sigma)$. The density measurements of autobrecciated material in Unit $\mathrm{V}$ are more variable than those found in the vesicular basalts of Unit IV, in keeping with the heterogeneous nature of this unit (see "Sedimentology" and "Igneous petrology").

Porosities in the upper sedimentary units are high (between 20\% and 40\%). Throughout the vesicular basalts of Unit IV, porosity decreases (1.5\%-15.8\%), with an average of $9.2 \% \pm 8.0 \%(2 \sigma)$. The lowermost autobrecciated basalts of Unit $\mathrm{V}$ once again display variation, with porosity ranging from $8.0 \%$ to $33.5 \%$.

\section{Compressional ( $P$-wave) velocity}

Downhole variation of compressional wave velocity is shown in Figure F61 and listed in Table T8. Figure F62 illustrates the negative correlation of $P$-wave velocity with porosity and positive correlation of $P$ wave velocity with bulk density. There was no significant anisotropy observed in the samples. Figure F62 depicts the generally lower densities and $P$-wave velocities and higher porosities of the sedimentary units (Unit II and Subunit IIIa) compared with the igneous material from Units IV and V. The vesicular basalts of Unit IV have downhole velocities ranging between 4.3 and $7.1 \mathrm{~km} / \mathrm{s}$, similar to those found in igneous material at the other Expedition 324 sites. There is one outlier in Figure F62 from Core 324U1349A-10R. This sample lies off the trend to lower $P$-wave velocities for a given density and porosity. Visual examination of the sample did not reveal any obvious reason for the discrepancy.

\section{Thermal conductivity}

Thirty-seven measurements of thermal conductivity were performed on material recovered from Hole U1349A. The results are summarized in Table T9 and displayed in Figure F63. Thermal conductivity in sedimentary Unit II and Subunit IIIa was generally lower than measured in igneous material and ranged from 1.01 to $1.57 \mathrm{~W} /(\mathrm{m} \cdot \mathrm{K})$. The igneous material of Unit IV had an average thermal conductivity of 1.80 $\pm 0.36 \mathrm{~W} /(\mathrm{m} \cdot \mathrm{K})(2 \sigma ; N=22)$. The autobrecciated basalts of Unit $\mathrm{V}$ showed a decrease in thermal conductivity compared to Unit IV, averaging $1.36 \pm 0.31$ $\mathrm{W} /(\mathrm{m} \cdot \mathrm{K})(2 \sigma ; N=10)$. This is plausibly due to the higher porosity of this unit, since thermal conductivity of rock is greater than pores filled with air or water.

\section{Paleomagnetism}

Recovered core materials in Hole U1349A show diverse magnetic properties. We analyzed 32 discrete samples from volcanic rocks. The topmost recovered cores as well as the deepest cores (324-U1349A-5R and 16R) are mostly composed of volcanic breccias (see "Igneous petrology"). We are not certain if the primary magnetization directions of the material in these cores survived during autobrecciation and lava deposition. This material likely carries a depositional remanent magnetization (DRM). The basalts recovered from Cores 324-U1349-7R through 15R show evidence of a possible chemical remanent magnetization (CRM). Consequently, any directional result must be interpreted with care.

We used the $2 \mathrm{G}$ Enterprises cryomagnetometer for some of the volcaniclastic sample measurements because the natural remanent magnetization (NRM) of these samples was too weak to be measured on the Molspin Minispin magnetometer (a few tens of milliamps per meter). Alternating-field (AF) demagnetization and thermal demagnetization were carried out using the DTech degausser and Schonstedt oven, respectively. The NRM bulk magnetic susceptibilities of most of our samples are on the order of $10^{-3} \mathrm{SI}$, which is an order of magnitude smaller than the values of basalts recovered from Holes U1346A and U1347A. 


\section{Working-half discrete sample measurements}

\section{Alternating-field demagnetizations}

Three types of behaviors that roughly correlate to the igneous lithology were observed in AF demagnetization measurements in Hole U1349A. The first type, observed in the three samples from Core 324U1349A-5R, is characterized by a very low NRM. Two out of the three samples show several components that are difficult to separate on the orthogonal vector diagram (Fig. F64A). Only one sample gives a demagnetization result with a maximum angular deviation $<8^{\circ}$.

The second type of behavior, present in Cores 324U1349-7R through $14 \mathrm{R}$, is very different from that observed in recovered fine-grained igneous rocks in Holes U1346A and U1347A (Fig. F64B). The magnetization is very stable, with median destructive fields (MDFs) on the order of 20-25 $\mathrm{mT}$ and an initial plateau on the demagnetization spectra that is characteristic of single-domain grains. A large part of the remanent magnetization (up to 25\%) is not demagnetized at $150 \mathrm{mT}$, the maximum AF field for the DTech degausser. Both the drilling-induced and viscous remanent magnetization overprints are very small in samples from this section. All AF demagnetizations are univectorial between $\sim 10$ and $150 \mathrm{mT}$, and the inclinations given by principal component analysis (PCA) (Kirschvink, 1980) are all negative and shallow with an average of $-5.0^{\circ} \pm 5.0^{\circ}(1 \sigma)$.

The third type of behavior is observed in samples from Core 324-U1349-16R. Two samples are volcaniclastics and one is a from a lava pod (see "Igneous petrology"). These samples have a very low magnetization, lower MDFs than the samples from the section above, and several components on the Zijderveld diagram. However, it is possible to define a linear component pointing toward the origin after demagnetization to $20 \mathrm{mT}$.

Interpretations of resulting inclinations from these three types are difficult for various reasons. For the samples of the first type (volcaniclastics), the magnetization is not a thermoremanent magnetization (TRM) but a DRM. It is difficult to estimate when and in which conditions it was acquired. The secondtype samples (amygdaloidal basalt) are ideal field recorders from a rock magnetism point of view because their remanence is extremely stable and they give very consistent inclination values (Table T10). Thin section observations indicate that both hematite and titanomagnetite that have suffered oxy-exsolution are present in these cores (see "Igneous petrology"). However, it is unclear which of these two minerals carries the magnetization component that defines the characteristic remanent magnetization. If it is the titanomagnetite, then the magnetization is a true TRM. Otherwise, it is a CRM acquired when the hematite was formed (see "Alteration and metamorphic petrology" and "Thermal demagnetizations"). In the third group, the only sample that carries a true TRM is a fine-grained basalt sample with an inclination of $-13.8^{\circ}$.

\section{Thermal demagnetizations}

No samples taken from volcaniclastics were used for thermal demagnetizations because this rock type is too fragile for multiple heating steps. Three characteristic behaviors are apparent in thermal demagnetization results from basalts that roughly correlate to the igneous lithology. The first type of thermal demagnetization behavior (samples from Sections 324U1349A-7R-3 through 13R-5) is characterized by high, small-range unblocking temperatures around $500^{\circ} \mathrm{C}$ (Fig. F64C). This temperature indicates that the magnetization is probably carried by almost pure magnetite. Demagnetization results typically show a single component once the drilling overprint is removed after heating to $\sim 400^{\circ} \mathrm{C}$. Some samples show one point that deviates from the main direction around $475^{\circ}-525^{\circ} \mathrm{C}$, which might be a systematic error in that particular temperature step or might represent the statistical variability in the directions. Sample 324-U1349A-12R-4, 40-42 cm, has a different behavior; its magnetization decreases almost linearly from $100^{\circ} \mathrm{C}$ and then drops at $500^{\circ} \mathrm{C}$, probably indicating the presence of titanomagnetite (-maghemite) with a large range of Ti content (Hunt et al., 1995). This sample did not allow us to define a stable component by PCA with a maximum angular deviation $<8^{\circ}$. All other samples gave consistent negative shallow inclinations (Table T10). Possessing the second type of thermal demagnetization characteristics, samples from Sections 324-U1349A-14R-2 through 15R-1 (Fig. F64D) exhibit magnetization that decreases almost linearly from $100^{\circ} \mathrm{C}$ to $\sim 450^{\circ}-500^{\circ} \mathrm{C}$ and then drops at $\sim 540^{\circ} \mathrm{C}$. Similar to Sample 324U1349A-12R-4, 40-42 cm, this seems to indicate a range of Ti content as well as the presence of an almost pure magnetite phase. After removal of the overprint by $150^{\circ} \mathrm{C}$, the magnetization follows a univectorial decay toward the origin. PCA gives negative inclinations quite different from each other. One sample had severely erratic behavior and had to be rejected (Sample 324-U1349A-15R-3, 30-32 cm). Possessing the third type of thermal demagnetization characteristics, samples from Sections 324-U1349A15R-3 through 15R-5 had inconsistent and erratic behavior and were not taken into account in the rest of the analysis. 
During thermal demagnetization, no particular pattern was found in the bulk susceptibility variation after each heating step. In some cases, the susceptibility stayed constant until $640^{\circ} \mathrm{C}$, in other cases it doubled when heated over $500^{\circ} \mathrm{C}$, but in most cases it decreased more or less linearly between $300^{\circ}$ and $600^{\circ} \mathrm{C}$ to half its room temperature value. This variability of behaviors indicates complex magnetic mineralogy with a mixture of different phases. Onshore rock magnetism experiments will be crucial to understand this complex behavior for the interpretation of these results.

\section{Implications for lava deposition history}

The average inclination in Hole U1349A was calculated from both $\mathrm{AF}$ and thermal demagnetization results with maximum angular deviation values $<8^{\circ}$ from Cores 324-U1349A-7R through 14R (massive basalt flows). The average inclination is $-4.3^{\circ} \pm 5.9^{\circ}$ $(1 \sigma)$ (Fig. F65), suggesting the lavas in Hole U1349A were formed near the magnetic equator, assuming that the magnetization carried by these rocks is a true TRM and not a CRM.

The inclination inconsistency in the volcaniclastic section is probably a result of directions of primary magnetization that were rotated during deposition of these volcanic sediments.

\section{Downhole Logging}

Downhole logging data obtained in Hole U1349A included natural and spectral gamma ray, density, and electrical resistivity measurements from three depths of investigation. Interpretations of gamma ray and electrical resistivity downhole logs were used to identify 15 logging units in Hole U1349A, with 1 in the section covered by the bottom-hole assembly (BHA), 5 in the sedimentary sequences in the open hole interval, and 13 in the basaltic basement section.

\section{Operations}

A wiper trip was completed throughout the open hole, and the RCB bit was released at the bottom of the hole using the mechanical bit release before the start of wireline logging operations. The hole was displaced using $56 \mathrm{bbl}$ of barite mud, and the drill pipe was set at a depth of $118.9 \mathrm{~m}$ wireline matched depth below seafloor (WMSF). Logging operations in Hole U1349A consisted of two tool string deployments and took place in good sea conditions with ship heave fluctuating between 0.5 and $1.5 \mathrm{~m}$. Downhole logging operations began at $2020 \mathrm{~h}$ on 11 October 2009 and were concluded at $0950 \mathrm{~h}$ on 12
October after the tools from the second tool string were rigged down.

\section{Tool string deployment HNGS-HLDS-DITE}

The wireline tool string deployment consisted of a $22 \mathrm{~m}$ long modified triple combo tool string that included a logging equipment cable head (LEH-QT), digital telemetry cartridge (DTC-H), Hostile Environment Natural Gamma Ray Sonde (HNGS), Hostile Environment Natural Gamma Ray Cartridge (HNGC), Hostile Environment Litho-Density Sonde Cartridge, Hostile Environment Litho-Density Sonde (HLDS), and Digital Dual Induction Tool model E (DITE). During the initial descent, the short spacing sensor in the HLDS began giving high voltage readings. The tool had tested within normal parameters during the initial check on the rig floor. After several checks, the logging operation continued without the short spacing measurements. The tool string was lowered to a depth of $3079 \mathrm{~m} \mathrm{DRF}$ at $\sim 1160 \mathrm{~m} / \mathrm{h}$. Downhole logs were recorded in a downlog from seafloor to $248 \mathrm{~m} \mathrm{WMSF}$ at $550 \mathrm{~m} / \mathrm{h}$, in uplog Pass 1 from 250 to $103.5 \mathrm{~m} \mathrm{WMSF}$ at $275 \mathrm{~m} / \mathrm{h}$, and in repeat uplog Pass 2 from $250 \mathrm{~m}$ WMSF to seafloor at $550 \mathrm{~m} / \mathrm{h}$.

\section{HNGS-GPIT-FMS}

The second wireline tool string deployment consisted of a $34.39 \mathrm{~m}$ long FMS-sonic tool string that included an LEH-QT, DTC-H, HNGS, HNGC, digital telemetry adapter, General Purpose Inclinometry tool (GPIT), and FMS. Downhole logs were recorded in a downlog from seafloor to $222 \mathrm{~m}$ WMSF at 550 $\mathrm{m} / \mathrm{h}$ and in uplog Pass 1 from 250 to $148 \mathrm{~m}$ WMSF. A second uplog Pass 2 was recorded from $250 \mathrm{~m}$ WMSF to seafloor at $550 \mathrm{~m} / \mathrm{h}$.

\section{Data processing}

Logging data were recorded onboard by Schlumberger and archived in digital log information standard (DLIS) format. Data were sent by satellite transfer to the Lamont-Doherty Earth Observatory Borehole Research Group, processed there, and transferred back to the ship for archival in the shipboard database. Processing and data quality notes are given below.

\section{Depth shifting}

In general, depth shifts that are applied to logging data by selecting a reference (base) log (usually the total gamma ray log from the run with the greatest vertical extent and no sudden changes in cable speed) and features in equivalent logs from other 
passes are aligned by eye. The downhole logs were first shifted to the seafloor based on the logger's seafloor depth of $3133 \mathrm{~m}$ wireline depth below rig floor (Table T11). This depth differs $5 \mathrm{~m}$ from the drillers bottom-felt depth. The depth-shifted logs were then depth matched to those of HNGS-HLDS-DITE tool string Pass 2.

\section{Data quality}

The quality of wireline logging data was assessed by evaluating whether logged values are reasonable for the lithologies encountered and by checking consistency between different passes of the same tool. Gamma ray logs recorded through the BHA should be used only qualitatively because of the attenuation of the incoming signal. The thick-walled BHA attenuates the signal more than the thinner walled drill pipe. In addition, the photoelectric effect measurements are strongly affected by the use of heavier mud.

A wide $(>30.5 \mathrm{~cm})$ and/or irregular borehole affects most recordings, particularly those like the HLDS that require eccentralization and a good contact with the borehole wall. The density log roughly correlates with the resistivity logs, but it is largely affected by hole conditions. Hole diameter measurements were recorded with the hydraulic caliper on the HLDS tool (LCAL) and show a very irregular borehole. Good repeatability was observed between Pass 1 and Pass 2, particularly for measurements of electrical resistivity, gamma radiation, and density.

The FMS images are generally of good quality below $220 \mathrm{~m}$ WMSF as a result of the relatively good hole condition (hole size $<35.6 \mathrm{~cm}$ ) and of intermediate quality above $220 \mathrm{~m}$ WMSF because of the larger borehole size, ranging from 26 to $43 \mathrm{~cm}$ (Fig. F66). The irregular and possibly elliptical shape of the borehole occasionally prevented some FMS pads from being in direct contact with the formation, resulting in poor-resolution or dark images. Hence, the FMS images (and the high-resolution resistivity logs) should be used with caution in this depth interval.

The sea state was relatively calm with a peak to peak heave of $\sim 1.2 \mathrm{~m}$ or less. The wireline heave compensator was used during the entire logging operation.

\section{Preliminary results}

\section{Electrical resistivity measurements}

Three electrical resistivity curves were obtained with the DITE. The spherically focused resistivity (SFLU), medium induction phasor-processed resistivity (IMPH), and deep induction phasor-processed resistivity (IDPH) profiles represent different depths of investigation into the formation $(64,76$, and 152 $\mathrm{cm}$, respectively) and different vertical resolutions $(76,152$, and $213 \mathrm{~cm}$, respectively). Downhole electrical resistivity measurements covered $129.4 \mathrm{~m}$ of the open hole sedimentary and basement lithostratigraphic sequences drilled in Hole U1349A (Fig. F66). The DITE was the only tool that reached the bottom of the logged interval in Hole U1349A because it was the bottommost tool in the logging tool string (see Fig. F19 in the "Methods" chapter).

In the $24 \mathrm{~m}$ of sedimentary sequence in open hole the resistivity measurements are consistent with minimal sediment variability. IMPH and IDPH average $1.5 \Omega \mathrm{m}$, whereas SFLU averages $1.2 \Omega \mathrm{m}$. In the basaltic basement units, resistivity shows large variability with a general trend of increasing values downhole, with the exception of logging Unit XIIIb (stratigraphic Unit V) where resistivity values tend to be more uniform (Fig. F66).

\section{Gamma ray measurements}

Standard, computed, and individual spectral contributions from ${ }^{40} \mathrm{~K},{ }^{238} \mathrm{U}$, and ${ }^{232} \mathrm{Th}$ were part of the gamma ray measurements obtained in Hole U1349A with the HNGS. The total gamma ray measurements through the BHA show one significant anomaly, a peak between 74.1 and $82.9 \mathrm{~m}$ WMSF (Fig. F66).

Downhole gamma ray measurements in the open hole covered $45.2 \mathrm{~m}$ of the sedimentary sequences and $82.9 \mathrm{~m}$ of the basement lithostratigraphic units. Total gamma ray measurements in the sediments of Hole U1349A show little variability in logging Units Is and IIs (see "Lithostratigraphic correlations"), ranging from 7.9 to 19.6 gAPI, with a mean of 11.7 gAPI. Logging Units IIIs-Vs show an increase in total gamma radiation at the top of Unit IIIs. Potassium $(<1 \mathrm{wt} \%), \mathrm{U}(<1 \mathrm{ppm})$, and Th $(<1 \mathrm{ppm})$ values are all low and show little variability in Units Is and IIs (Fig. F67). In logging Units IIIs-Vs, $\mathrm{K}$ and $\mathrm{U}$ have higher values, with a large peak in U in logging Unit IIIs.

Total gamma ray measurements in the basaltic basement units are considerably higher than those obtained in logging Units Is and IIs, with values ranging between 11.5 and 116.5 gAPI (Fig. F66).

Potassium values are relatively high in the basaltic basement and logging Unit IIIs compared to the shallower sediment section, with values between 0.6 and $3.0 \mathrm{wt} \%$ (Fig. F67). Uranium values are mostly between 0.0 and $0.7 \mathrm{ppm}$ (Fig. F67). Uranium is the largest contributor to the peak in total gamma radiation between 143.5 and $148.6 \mathrm{~m}$ WMSF, with a high value of $7.8 \mathrm{ppm}$. Thorium ranges from 0.0 to 2.0 ppm, with a mean of 0.5 ppm (Fig. F67). 


\section{Density measurements}

Density values range from 1.5 to $2.8 \mathrm{~g} / \mathrm{cm}^{3}$ over the sediment section of the open hole (Fig. F68). In the basaltic basement section, density values are between 1.7 and $2.9 \mathrm{~g} / \mathrm{cm}^{3}$. A comparison between discrete physical property samples and downhole density log shows that discrete sample data (MAD) are consistent with the downhole data (Fig. F68).

\section{Magnetic field measurements}

Measurements of total magnetic moment, magnetic inclination, magnetic intensity, and hole deviation were obtained with the GPIT (Fig. F69). The mean magnetic inclination and total magnetic moment from 148 to $250 \mathrm{~m}$ WMSF are $\sim 50^{\circ}$ and 0.47 Oe, respectively. The magnetic intensity is 0.37 Oe on the $z$-axis and varies between -0.3 and 0.30 Oe on the $x$ and $y$-axes. The mean hole deviation using Pass 1 is $1.1^{\circ}$.

\section{Formation MicroScanner images}

FMS images were obtained for the open hole interval between 160 and $250 \mathrm{~m}$ WMSF. The diameter of the hole recorded by the FMS calipers varies between 25 and $43 \mathrm{~cm}$. High-quality FMS images were obtained in sections of the hole with a diameter $<35.6 \mathrm{~cm}$. FMS images from the basaltic basement section show sections with subhorizontal contacts, moderately dipping contacts, and vesicular or brecciated textures (Figs. F70, F71).

\section{Lithostratigraphic correlations}

Preliminary interpretation of the downhole log data divided Hole U1349A into 19 logging units within 3 main sections: the section covered by the BHA, the sedimentary sequences in open hole, and the basaltic basement sequences (Figs. F66, F67, F68). Logging units in the section covered by the BHA were interpreted on the basis of the gamma ray downhole logs, and only intervals that showed significant anomalies were characterized as logging units. Logging units within the open hole section that contain sedimentary sequences were also interpreted on the basis of the gamma ray fluctuations, whereas the basement sequence was characterized using both the gamma ray and resistivity logs.

One logging unit was qualitatively identified in the section covered by the pipe (Fig. F66):

- Logging Unit Ip (74.1-82.9 m WMSF) is distinguished by an increase in total gamma ray measurements. Spectral gamma data indicates large contributions from U, Th, and K (Figs. F66, F67).
Five logging units were identified in the sedimentary sequence in open hole below the BHA based on gamma ray downhole logs (Fig. F66):

- Logging Unit Is (119.7-127.2 m WMSF) is characterized by gradual increases in resistivity, density, and gamma ray measurements. Gamma radiation decreases at the base of this unit. Spectral gamma ray measurements indicate a peak in potassium to $\sim 1 \mathrm{wt} \%$.

- Logging Unit IIs (127.2-143.1 m WMSF) is defined by a decrease in total gamma ray measurements at the top of the unit. Resistivity values show a gradual increase throughout the unit (Fig. F67). Density data increase sharply in the middle of the unit (Fig. F68), corresponding to the boundary between nannofossil ooze and sand-silt-claystones. Spectral gamma data indicate that uranium, potassium, and thorium are low throughout the unit.

- Logging Unit IIIs (143.1-148.5 m WMSF) is defined by a sharp increase in resistivity, with maximum values of $\sim 33 \Omega \mathrm{m}$. Gamma ray measurements increase to 117 gAPI (Fig. F66). Spectral gamma ray data indicate that uranium makes the largest contribution to this peak, with a value of $7.7 \mathrm{ppm}$.

- Logging Unit IVs (148.5-155.2 m WMSF) decreases sharply in resistivity and total gamma radiation. Spectral gamma ray measurements indicate that thorium, uranium, and potassium are low (Fig. F67). Density is $\sim 2.0 \mathrm{~g} / \mathrm{cm}^{3}$ in this unit (Fig. F68).

- Logging Unit Vs (155.2-165.1 m WMSF) has low resistivity values and high total gamma ray values throughout the unit. Gamma ray values are mostly controlled by uranium readings, which peak at $3.0 \mathrm{ppm}$ (Fig. F67). Density values steadily increase through the unit to $164.7 \mathrm{~m} \mathrm{WMSF}$, where they increase sharply.

The basement sequence below $165.1 \mathrm{~m} \mathrm{WMSF}$ is divided into 13 logging units using the downhole resistivity and natural gamma logs (Fig. F66):

- Logging Unit Ib (165.1-170.1 m WMSF) increases sharply in resistivity values (Fig. F66). Total gamma radiation decreases in this unit. Density values are high, averaging $\sim 2.6 \mathrm{~g} / \mathrm{cm}^{3}$.

- Logging Unit IIb (170.1-176.9 m WMSF) is characterized by a decrease in resistivity and gamma ray values (Fig. F66). Potassium increases, whereas U and Th have low values. Density decreases through the unit but sharply increases near the base of the unit (Fig. F68). 
- Logging Unit IIIb (176.9-179.1 m WMSF) has high resistivity values and a small peak in gamma radiation (Fig. F66). Spectral gamma data indicate that the peak is due to a contribution from $\mathrm{K}$, with low Th and U (Fig. F67). Bulk density is high throughout the interval (Fig. F68).

- Logging Unit IVb (179.1-185.8 m WMSF) is defined by a sharp decrease in resistivity values at the top of the unit. Gamma radiation increases at the top of the unit and then decreases in the lower part of the unit (Fig. F66). Density data decrease sharply at the top of the unit and gradually increase until reaching $185.3 \mathrm{~m}$ WMSF, where a sharp increase occurs (Fig. F68).

- Logging Unit Vb (185.8-188.6 m WMSF) increases sharply in resistivity values, whereas gamma ray values decrease. Spectral gamma data indicate that potassium, thorium, and uranium are low (Fig. F67). Density values decrease sharply through the unit (Fig. F68).

- Logging Unit VIb (188.6-190.4 m WMSF). Resistivity values decrease sharply at the top of the unit. Gamma ray data show a peak that has a large contribution from potassium (Figs. F66, F67). Thorium and uranium are low. Density values within the unit are high.

- Logging Unit VIIb (190.4-192.6 m WMSF) is characterized by high resistivity values, whereas total gamma ray values are low. Density decreases sharply and values are low throughout the unit.

- Logging Unit VIIIb (192.6-197.8 m WMSF) is defined by sharply decreasing resistivity values at the top of the unit. Total gamma ray increases sharply at the top of the unit and then stays consistently high throughout the unit (Fig. F66). Potassium values are high throughout the unit. Density values are high and show an increasing trend throughout the unit (Fig. F68).

- Logging Unit IXb (197.8-206.8 m WMSF) is defined by a sharp increase in resistivity increases sharply at the top of the unit that steadily increases to higher values. Total gamma radiation steadily decreases throughout the unit (Fig. F66). Thorium and $U$ values in the unit are low, whereas $\mathrm{K}$ shows a similar trend to the total gamma ray curve, indicating that the total gamma ray is mostly controlled by the contribution from potassium. Density values increase throughout the unit.

- Logging Unit Xb (206.8-210.8 m WMSF) is characterized by increasing resistivity values, particularly the SFLU values that peak at $1200 \Omega$ m. Total gamma radiation is low. Density values are high but show a decreasing trend in the unit.
- Logging Unit XIb (210.8-217.9 m WMSF) is characterized by SFLU values that decrease at the top of the unit but otherwise remain fairly constant. Total gamma ray values show an increasing trend though the unit, whereas density values show a decreasing trend with increasing depth.

- Logging Unit XIIb (217.9-223.5 m WMSF) is characterized by increasing resistivity values at the top of the unit. Total gamma radiation decreases slightly in the unit, whereas density values sharply decrease to very low values at the base of the unit.

- Logging Unit XIIIb (223.5-248.7 m WMSF) is defined by decreasing resistivity values at the top of the unit that remain steady to the base of the section. Total gamma ray data only cover the upper $11 \mathrm{~m}$ of the unit, showing a decreasing trend to the base of the unit. Density averages $\sim 2.4 \mathrm{~g} / \mathrm{cm}^{3}$ and exhibits some cyclicity.

\section{References}

Alt, J.C., 1995. Subseafloor processes in mid-ocean ridge hydrothermal systems. In Humphris, S.E., Zierenberg, R., Mullineaux, L., and Thomson, R. (Eds.), Seafloor Hydrothermal Systems: Physical, Chemical, Biological and Geological Interactions within Hydrothermal Systems. Geophys. Monogr., 91:85-114.

Alt, J.C., 2004. Alteration of the upper oceanic crust: mineralogy, chemistry, and processes. In Elderfield, H., and Davis, E. (Eds.), Hydrogeology of the Oceanic Lithosphere: New York (Cambridge Univ. Press), 456-488.

Asimow, P.D., Dixon, J.E., and Langmuir, C.H., 2004. A hydrous melting and fractionation model for midocean-ridge basalts: application to the Mid-Atlantic Ridge near the Azores. Geochem., Geophys., Geosyst., 5(1):Q01E16. doi:10.1029/2003GC000568

Bach, W., Hegner, E., Erzinger, J., and Satir, M., 1994. Chemical and isotopic variations along the superfast spreading East Pacific Rise from 6 to $30^{\circ} \mathrm{S}$. Contrib. Mineral. Petrol., 116(4):365-380. doi:10.1007/BF00310905

Bacon, C.R., and Druitt, T.H., 1988. Compositional evolution of the zoned calcalkaline magma chamber of Mount Mazama, Crater Lake, Oregon. Contrib. Mineral. Petrol., 98(2):224-256. doi:10.1007/BF00402114

Baker, I., and Haggerty, S.E., 1967. The alteration of olivine in basaltic and associated lavas. Contrib. Mineral. Petrol., 16(3):258-273. doi:10.1007/BF00371095

Banerjee, N.R., Honnorez, J., and Muehlenbachs, K., 2004. Low-temperature alteration of submarine basalts from the Ontong Java Plateau. In Fitton, J.G., Mahoney, J.J., Wallace, P.J., and Saunders, A.D. (Eds.), Origin and Evolution of the Ontong Java Plateau. Geol. Soc. Spec. Publ., 229(1):259-273. doi:10.1144/GSL.SP.2004.229.01.15

Bellier, J.-P., and Moullade, M., 2002. Lower Cretaceous planktonic foraminiferal biostratigraphy of the western North Atlantic (ODP Leg 171B), and taxonomic clarifi- 
cation of key index species. Rev. Micropaleontol., 45(1):926. doi:10.1016/S0035-1598(02)80003-4

Bougault, H., and Hekinian, R., 1974. Rift Valley in the Atlantic Ocean near $36^{\circ} 50^{\prime} \mathrm{N}$ : petrology and geochemistry of basalt rocks. Earth Planet. Sci. Lett., 24(2):249-261. doi:10.1016/0012-821X(74)90103-4

Bouma, A.H., 1962. Sedimentology of Some Flysch Deposits: A Graphic Approach to Facies Interpretation: Amsterdam (Elsevier).

Danyushevsky, L.V., 2001. The effect of small amounts of $\mathrm{H}_{2} \mathrm{O}$ on crystallization of mid-ocean-ridge and backarc basin magmas. J. Volcanol. Geotherm. Res., 110(3-4):265280. doi:10.1016/S0377-0273(01)00213-X

Davis, G.H., 1984. Structural Geology of Rocks and Regions: New York (John Wiley and Sons, Inc.).

Dixon, J.E., Clague, D.A., and Eissen, J.-P., 1986. Gabbroic xenoliths and host ferrobasalt from the southern Juan de Fuca Ridge. J. Geophys Res., [Solid Earth], 91(B3):37953820. doi:10.1029/JB091iB03p03795

Dixon, J.E., 1995. An experimental study of water and carbon dioxide solubilities in mid-ocean ridge basaltic liquids, Part II. Applications to degassing. J. Petrol., 36(6):1633-1646. http://petrology.oxfordjournals.org/cgi/reprint/36/6/1633

Dunlop, D.J., and Özdemir, Ö., 1997. Rock Magnetism: Fundamentals and Frontiers: Cambridge (Cambridge Univ. Press).

Eisenach, P., 1979. Petrography of opaque minerals in basalts drilled on DSDP Leg 45. In Melson, W.G., Rabinowitz, P.D., et al., Init. Repts. DSDP 45: Washington (U.S. Govt. Printing Office), 557-573. doi:10.2973/ dsdp.proc.45.131.1979

Fisher, R.V., 1960. Classification of volcanic breccias. Geol. Soc. Am. Bull., 71(7):973-982. doi:10.1130/00167606(1960)71[973:COVB]2.0.CO;2

Fitton, J.G., and Godard, M., 2004. Origin and evolution of magmas on the Ontong Java Plateau. In Fitton, J.G., Mahoney, J.J., Wallace, P.J., and Saunders, A.D. (Eds.), Origin and Evolution of the Ontong Java Plateau. Geol. Soc. Spec. Publ., 229(1):151-178. doi:10.1144/

GSL.SP.2004.229.01.10

Haggerty, S.E., 1991. Oxide textures: a mini-atlas. In Lindsley, D.H. (Ed.), Oxide Minerals: Petrologic and Magnetic Significance. Rev. Mineral., 25(1):129-219.

Haggerty, S.E., and Baker, I., 1967. The alteration of olivine in basaltic and associated lavas. Contrib. Mineral. Petrol., 16(3):233-257. doi:10.1007/BF00371094

Holbourn, A., Kuhnt, W., and Soeding, E., 2001. Atlantic paleobathymetry, paleoproductivity and paleocirculation in the late Albian: the benthic foraminiferal record. Palaeogeogr., Palaeoclimatol., Palaeoecol., 170(3-4):171196. doi:10.1016/S0031-0182(01)00223-1

Humphris, S.E., and Thompson, G., 1978. Trace element mobility during hydrothermal alteration of oceanic basalts. Geochim. Cosmochim. Acta, 42(1):127-136. doi:10.1016/0016-7037(78)90222-3

Hunt, C.P., Moskowitz, B.M., and Banerjee, S.K., 1995. Magnetic properties of rocks and minerals. In Ahrens, T.J. (Ed.), Rock Physics and Phase Relations: A Handbook of
Physical Constants. Am. Geophys. Union Ref. Shelf, 3:189-204.

Keszthelyi, L., Self, S., and Thordarson, T., 1999. Application of recent studies on the emplacement of basaltic lava flows to the Deccan traps. In Subbarao, K.V. (Ed.), Deccan Volcanic Province. Mem. Geol. Soc. India, 1:485520.

Kirschvink, J.L., 1980. The least-squares line and plane and the analysis of palaeomagnetic data. Geophys. J. R. Astron. Soc., 62(3):699-718. doi:10.1111/j.1365246X.1980.tb02601.x

Klaus, A., and Sager, W.W., 2002. Data report: high-resolution site survey seismic reflection data for ODP Leg 198 drilling on Shatsky Rise, northwest Pacific. In Bralower, T.J., Premoli Silva, I., Malone, M.J., et al., Proc. ODP, Init. Repts., 198: College Station, TX (Ocean Drilling Program), 1-21. doi:10.2973/odp.proc.ir.198.111.2002

Leeman, W.P., and Scheidegger, K.F., 1977. Olivine/liquid distribution coefficients and a test for crystal-liquid equilibrium. Earth Planet. Sci. Lett., 35(2):247-257. doi:10.1016/0012-821X(77)90128-5

Le Maitre, R.W., Bateman, P., Dudek, A., Keller, J., Lameyre, J., Le Bas, M.J., Sabine, P.A., Schmid, R., Sorensen, H., Streckeisen, A., Woolley, A.R., and Zanettin, B., 1989. A Classification of Igneous Rocks and Glossary of Terms: Oxford (Blackwell).

Lindsley, D.H., 1965. Iron-titanium oxides. Year Book-Carnegie Inst. Washington, 6:144-148.

Lowe, D.R., 1982. Sediment gravity flows, II. Depositional models with special reference to the deposits of highdensity turbidity currents. J. Sediment. Petrol., 52(1):279_ 297. http://jsedres.sepmonline.org/cgi/content/ abstract/52/1/279

Macdonald, G.A., 1968. Composition and origin of Hawaiian lavas. In Coats, R.R., Hay, R.L., and Anderson, C.A. (Eds.), Studies in Volcanology: A Memoir in Honor of Howel Williams. Mem.-Geol. Soc. Am., 116:477-522.

Macdonald, G.A., and Katsura, T., 1964. Chemical composition of Hawaiian lavas. J. Petrol., 5(1):82-133.

Mahoney, J.J., Fitton, J.G., Wallace, P.J., et al., 2001. Proc. ODP, Init. Repts., 192: College Station, TX (Ocean Drilling Program). doi:10.2973/odp.proc.ir.192.2001

Mahoney, J.J., Sinton, J.M., Kurz, M.D., Macdougall, J.D., Spencer, K.J., and Lugmair, G.W., 1994. Isotope and trace element characteristics of a super-fast spreading ridge: East Pacific Rise 13-23ㅇ. Earth Planet. Sci. Lett., 121(1-2):173-193. doi:10.1016/ 0012-821X(94)90039-6

Middleton, G.V., and Hampton, M.A., 1976. Subaqueous sediment transport and deposition by sediment gravity flows. In Stanley, D.J., and Swift, D.J.P. (Eds.), Marine Sediment Transport and Environmental Management: New York (Wiley), 197-218.

Nakanishi, M., Sager, W.W., and Klaus, A., 1999. Magnetic lineations within Shatsky Rise, northwest Pacific Ocean: implications for hot spot-triple junction interaction and oceanic plateau formation. J. Geophys. Res., [Solid Earth], 104(B4):7539-7556. doi:10.1029/1999JB900002

Natland, J.H., and Dick, H.J.B., 1996. Melt migration through high-level gabbroic cumulates of the East 
Pacific Rise at Hess Deep: the origin of magma lenses and the deep crustal structure of fast-spreading ridges. In Mével, C., Gillis, K.M., Allan, J.F., and Meyer, P.S. (Eds.), Proc. ODP, Sci. Results, 147: College Station, TX (Ocean Drilling Program), 21-58. doi:10.2973/ odp.proc.sr.147.002.1996

Ogg, J.G., Ogg, G., and Gradstein, F.M., 2008. The Concise Geologic Time Scale: Cambridge (Cambridge Univ. Press). http://www.cambridge.org/catalogue/catalogue.asp?isbn=9780521898492

Passchier, C.W., and Trouw, R.A.J., 1996. Microtectonics: Berlin (Springer-Verlag).

Retallack, G.J. 1991. Untangling the effects of burial alteration and ancient soil formation. Annu. Rev. Earth Planet. Sci., 19(1):183- 206. doi:10.1146/ annurev.ea.19.050191.001151

Righter, K., Leeman, W.P., and Hervig, R.L., 2006. Partitioning of $\mathrm{Ni}$, Co and $\mathrm{V}$ between spinel-structured oxides and silicate melts: importance of spinel composition. Chem. Geol., 227(1-2):1-25. doi:10.1016/j.chemgeo.2005.05.011

Sager, W.W., Kim, J., Klaus, A., Nakanishi, M., and Khankishieva, L.M., 1999. Bathymetry of Shatsky Rise, northwest Pacific Ocean: implications for ocean plateau development at a triple junction. J. Geophys. Res., [Solid Earth], 104(4):7557-7576. doi:10.1029/1998JB900009

Salters, V.J.M., and Longhi, J., 1999. Trace element partitioning during the initial stages of melting beneath mid-ocean ridges. Earth Planet. Sci. Lett., 166(1-2):1530. doi:10.1016/S0012-821X(98)00271-4

Sandwell, D.T., and MacKenzie, K.R., 1989. Geoid height versus topography for oceanic plateaus and swells. $J$. Geophys. Res., [Solid Earth], 94:7403-7418. doi:10.1029/ JB094iB06p07403

Sikora, P.J., and Olsson, R.K., 1991. A paleoslope model of late Albian to early Turonian foraminifera of the west Atlantic margin and North Atlantic Basin. Mar. Micropaleontol., 8(1-2):25-72. doi:10.1016/ 0377-8398(91)90005-Q

Sinton, J.M., Smaglik, S.M., Mahoney, J.J., and Macdonald, K.C., 1991. Magmatic processes at superfast spreading mid-ocean ridges: glass compositional variations along the East Pacific Rise $13^{\circ}-23^{\circ} \mathrm{S}$. J. Geophys. Res., [Solid Earth], 96:6133-6155. doi:10.1029/90JB02454
Skulski, T., Minarik, W., and Watson, E.B., 1994. High-pressure experimental trace-element partitioning between clinopyroxene and basaltic melts. Chem. Geol., 117(14):127-147. doi:10.1016/0009-2541(94)90125-2

Sliter, W.V., and Baker, R.A., 1972. Cretaceous bathymetric distribution of benthic foraminifers. J. Foraminiferal Res., 2(4):167-183. doi:10.2113/gsjfr.2.4.167

Smith, W.H.F., and Sandwell, D.T., 1997. Global sea floor topography from satellite altimetry and ship depth soundings. Science, 277(5334):1956-1962. doi:10.1126/ science.277.5334.1956

Soil Survey Division Staff, 1993. Soil Survey Manual (U.S. Department of Agriculture Handbook 18): Washington, DC (U.S. Govt. Printing Office). http://soils.usda.gov/ technical/manual/

Tejada, M.L.G., Mahoney, J.J., Duncan, R.A., and Hawkins, M.P., 1996. Age and geochemistry of basement and alkalic rocks of Malaita and Santa Isabel, Solomon Islands, southern margin of Ontong Java Plateau. J. Petrol. 37(2):361-394. doi:10.1093/petrology/37.2.361

Tejada, M.L.G., Mahoney, J.J., Neal, C.R., Duncan, R.A., and Petterson, M.G., 2002. Basement geochemistry and geochronology of Central Malaita, Solomon Islands, with implications for the origin and evolution of the Ontong Java Plateau. J. Petrol., 43(3):449-484. doi:10.1093/petrology/43.3.449

Walker, G.P.L., 1993. Mantle and magmatic processes: basaltic-volcano systems. Geol Soc. Spec. Publ., 76(1):338. doi:10.1144/GSL.SP.1993.076.01.01

Wallace, P.J., 1998. Pre-eruptive $\mathrm{H}_{2} \mathrm{O}$ and $\mathrm{CO}_{2}$ contents of mafic magmas from the submarine to emergent shield stages of Gran Canaria. In Weaver, P.P.E., Schmincke, H.U., Firth, J.V., and Duffield, W. (Eds.), Proc. ODP, Sci. Results, 157: College Station, TX (Ocean Drilling Program), 411-420. doi:10.2973/ odp.proc.sr.157.146.1998

Widdowson, M., 2007. Laterite and ferricrete. In Nash, D.J., and McLaren, S.J. (Eds.), Geochemical Sediments and Landscapes: Oxford, U. K. (Wiley-Blackwell).

Publication: 3 November 2010 MS 324-106 
Figure F1. Bathymetry of Ori Massif and location of Sites U1349 and U1350. Contours and colors indicate bathymetric depths predicted by satellite altimetry (Smith and Sandwell, 1997). Contours shown at $200 \mathrm{~m}$ intervals; dark contours shown for kilometer multiples. Red line $=$ track of Cruise TN037 site survey (Klaus and Sager, 2002). Site 1208 was cored during ODP Leg 198.

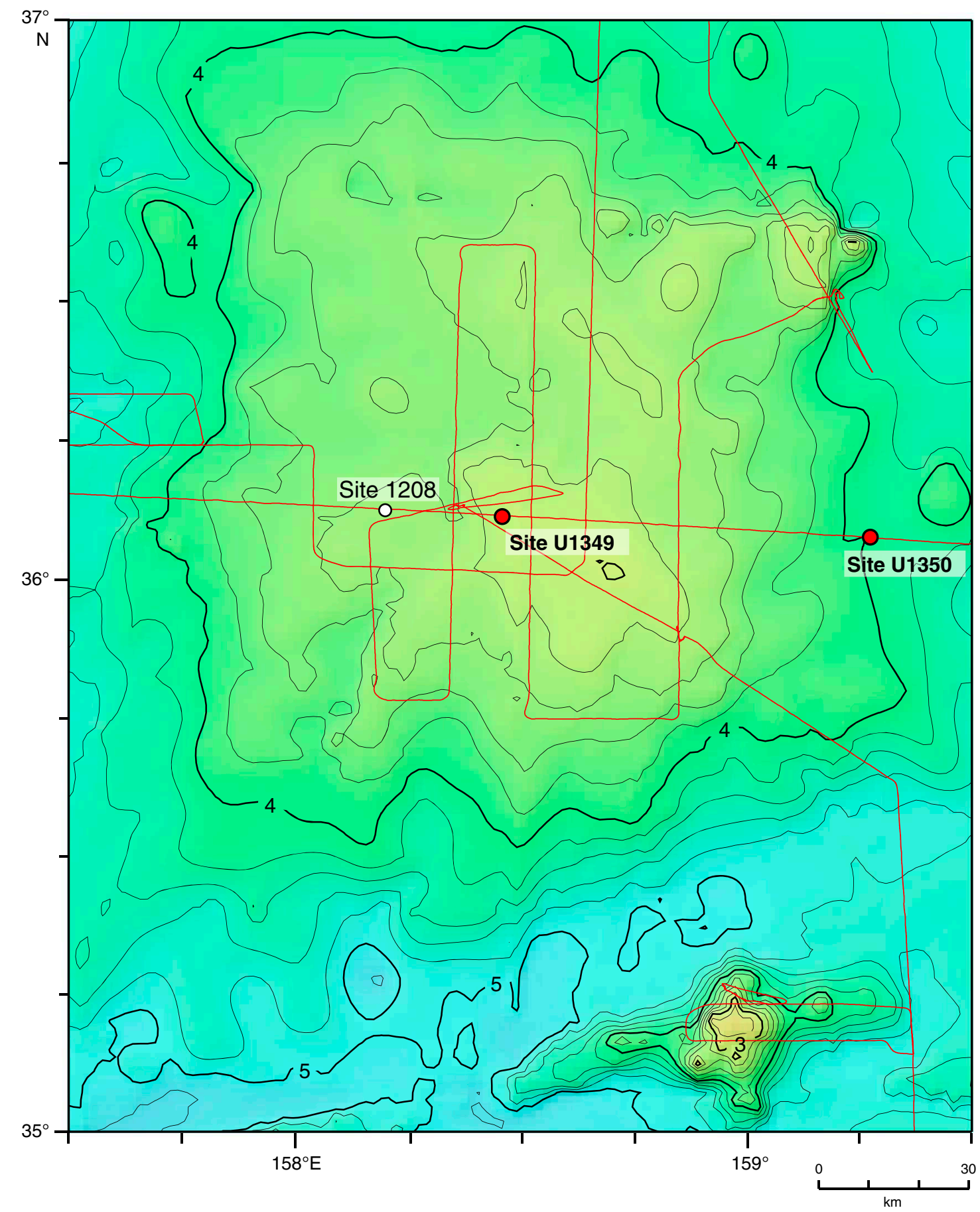


Figure F2. Seismic section and precruise layer interpretation (color overlay), Site U1349. See Klaus and Sager (2002).

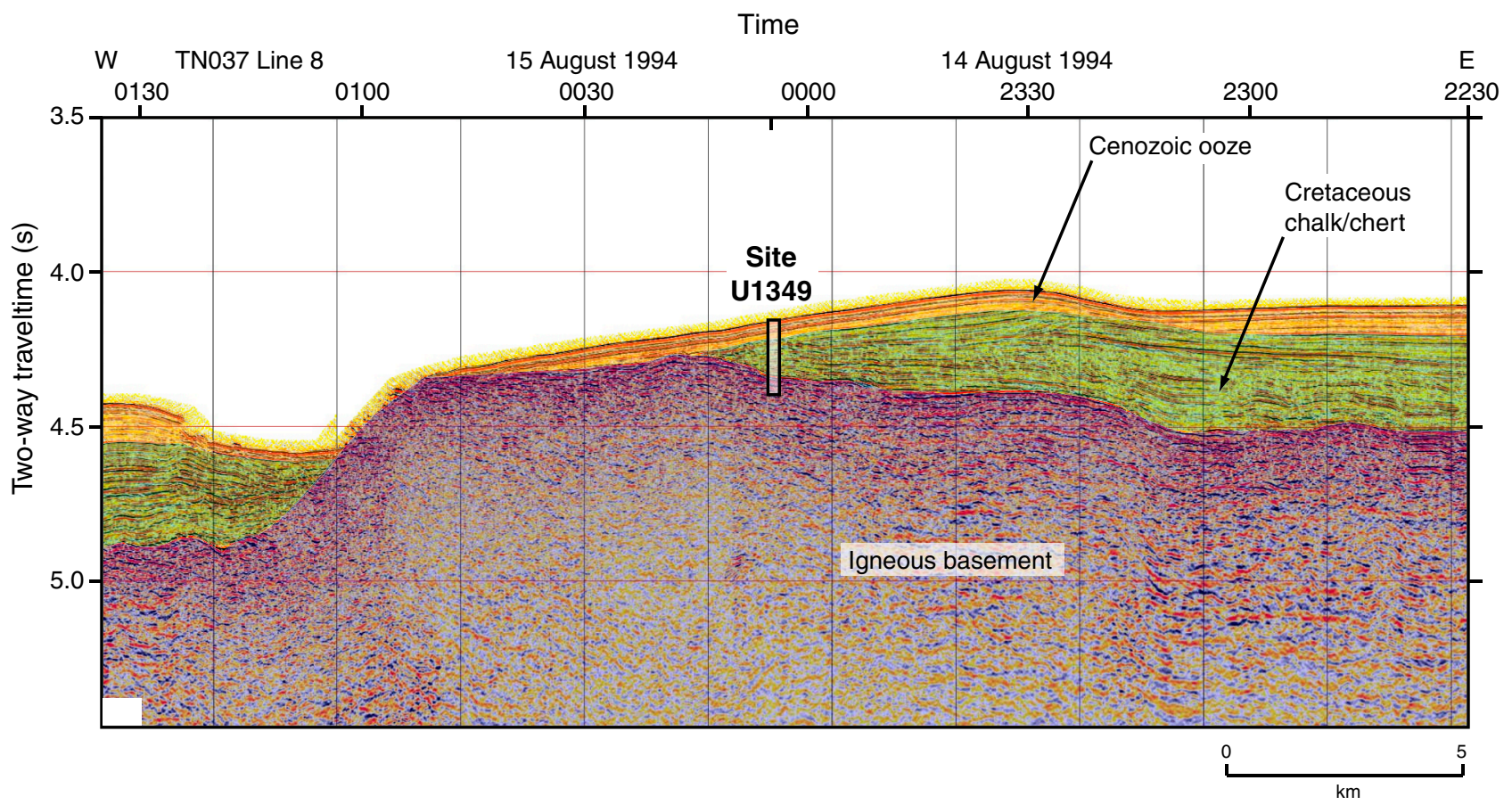


Figure F3. Close-up of the seismic section and precruise layer interpretation (color overlay), Site U1349. See Klaus and Sager (2002).

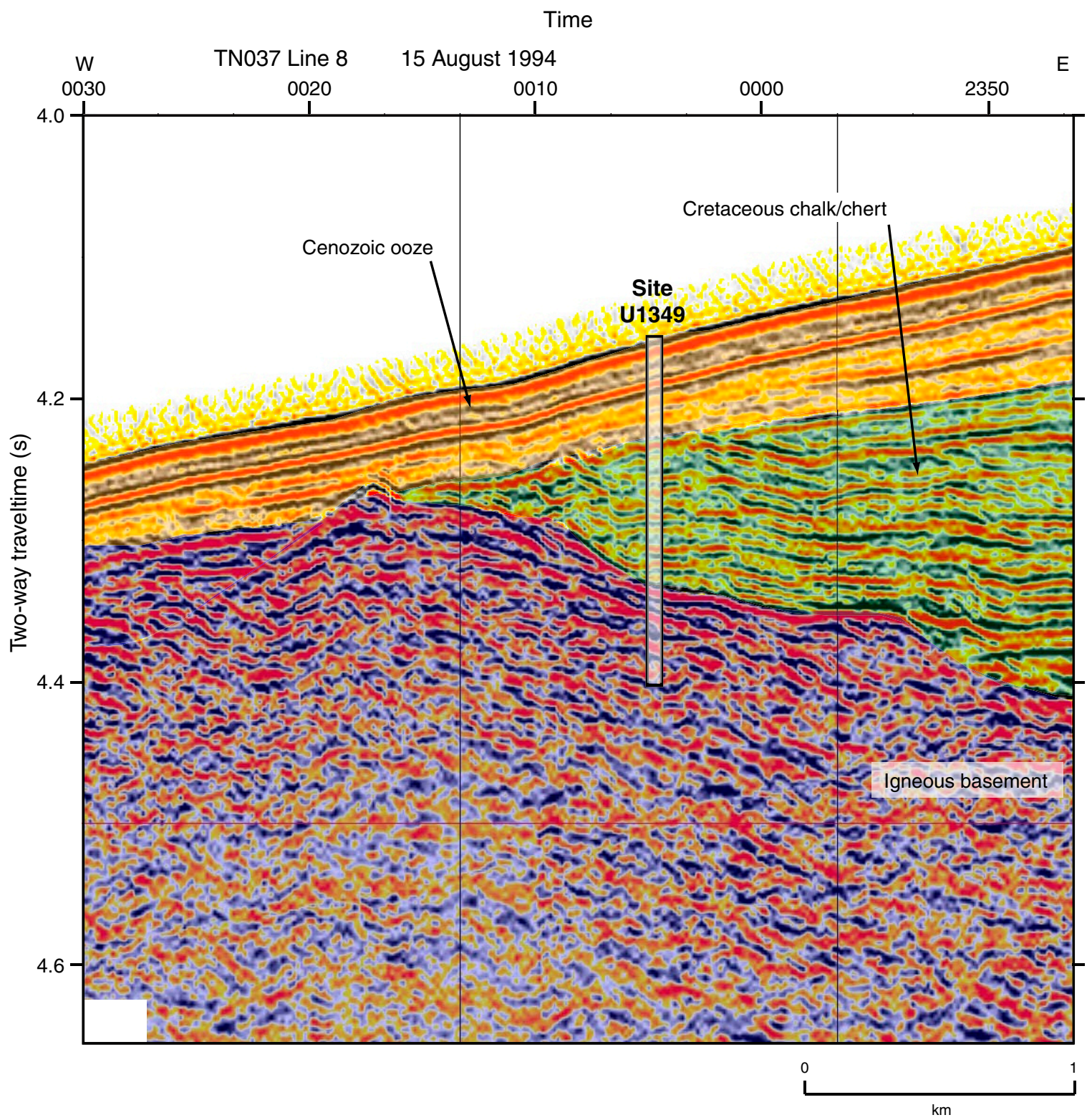


Figure F4. Plot of operation time vs. penetration depth, Hole U1349A. Dashed line = planned penetration progress, solid blue line $=$ actual depth achieved. $\mathrm{RCB}=$ rotary core barrel.

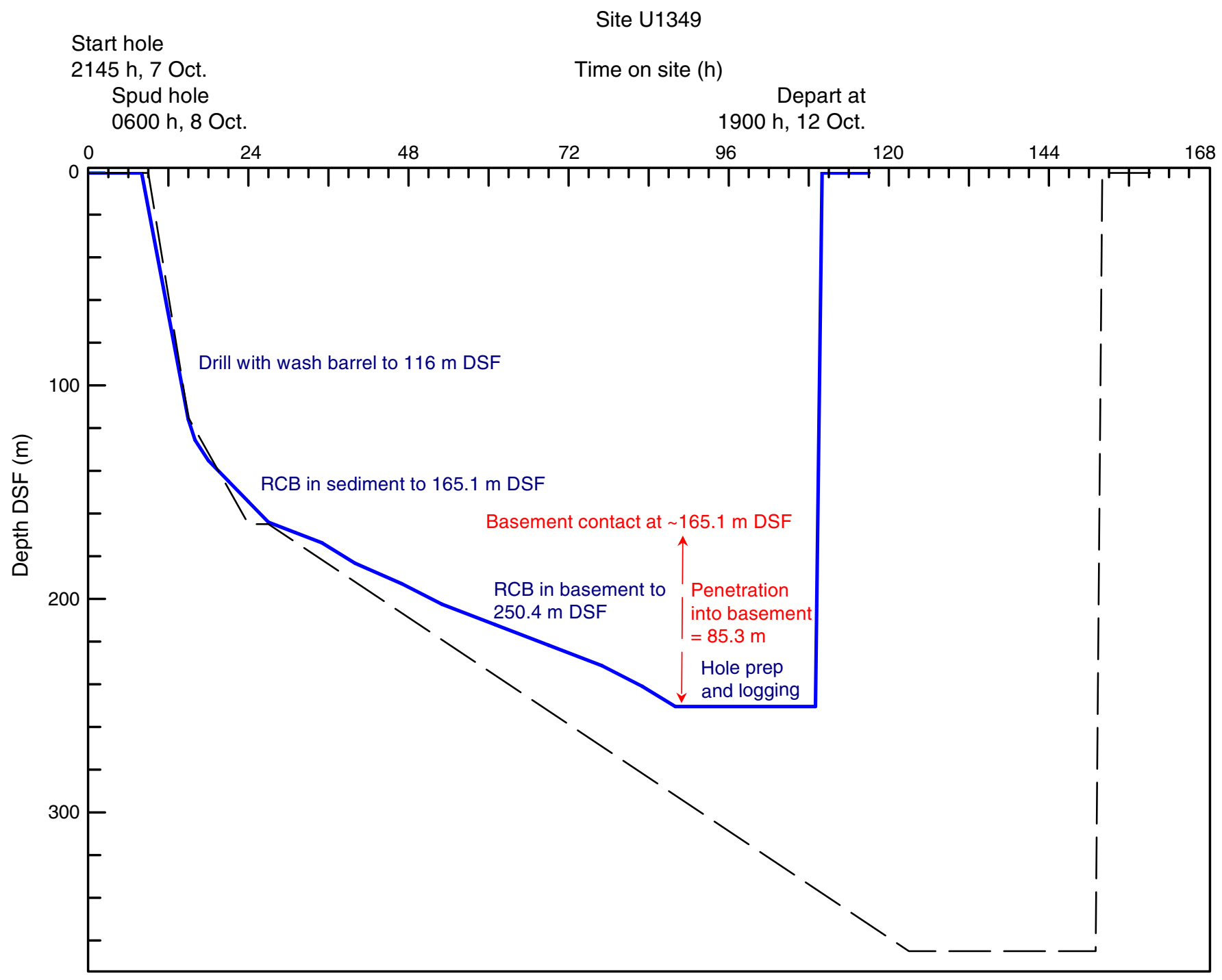


Figure F5. Lithostratigraphy, Site U1349. See "Igneous petrology" for details on igneous unit composition and structure.

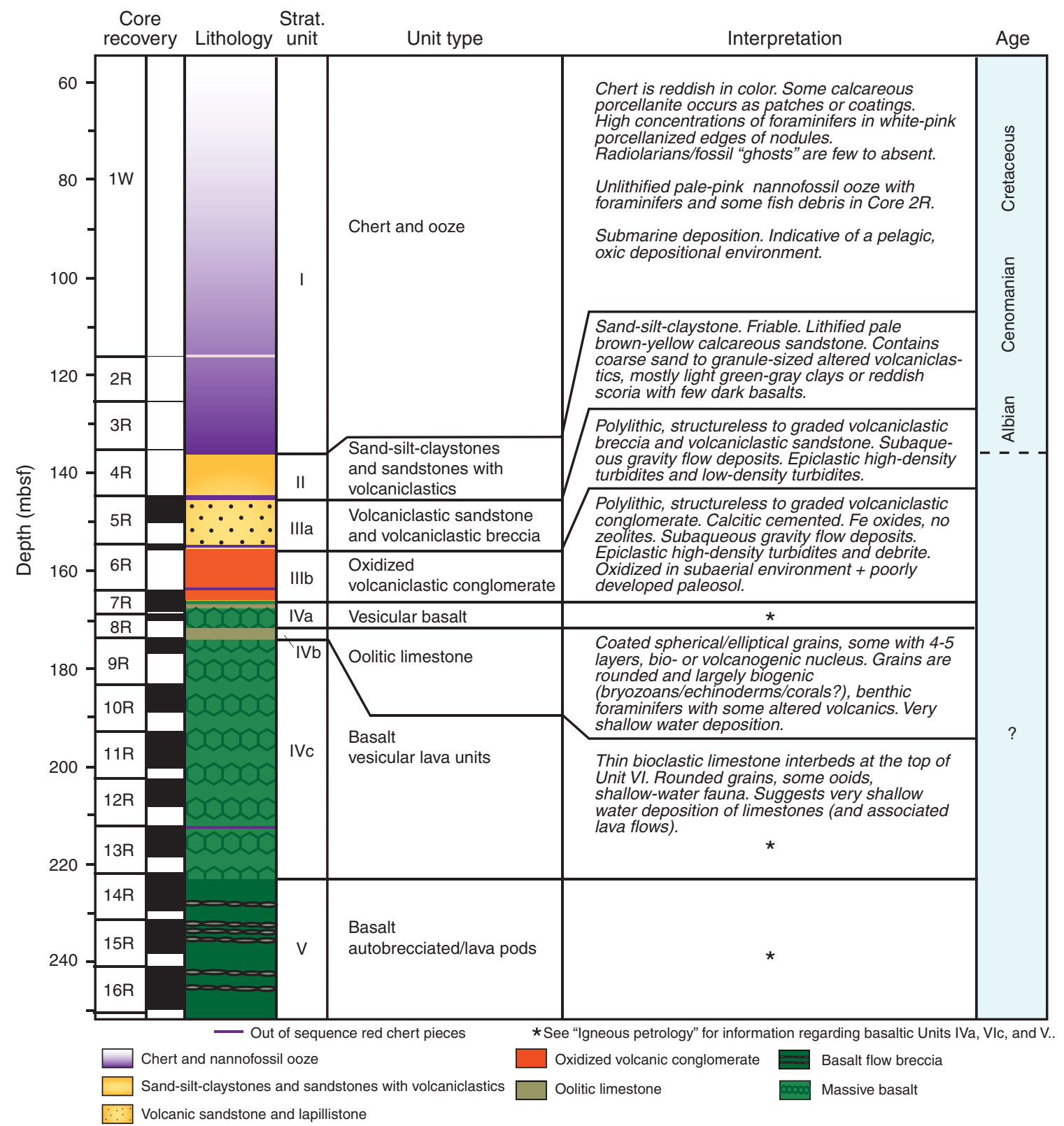


Figure F6. Photographs of polymictic conglomerate in stratigraphic Unit II, Hole U1349A. Interval 324-U1349A-5R-1, 0-6 cm
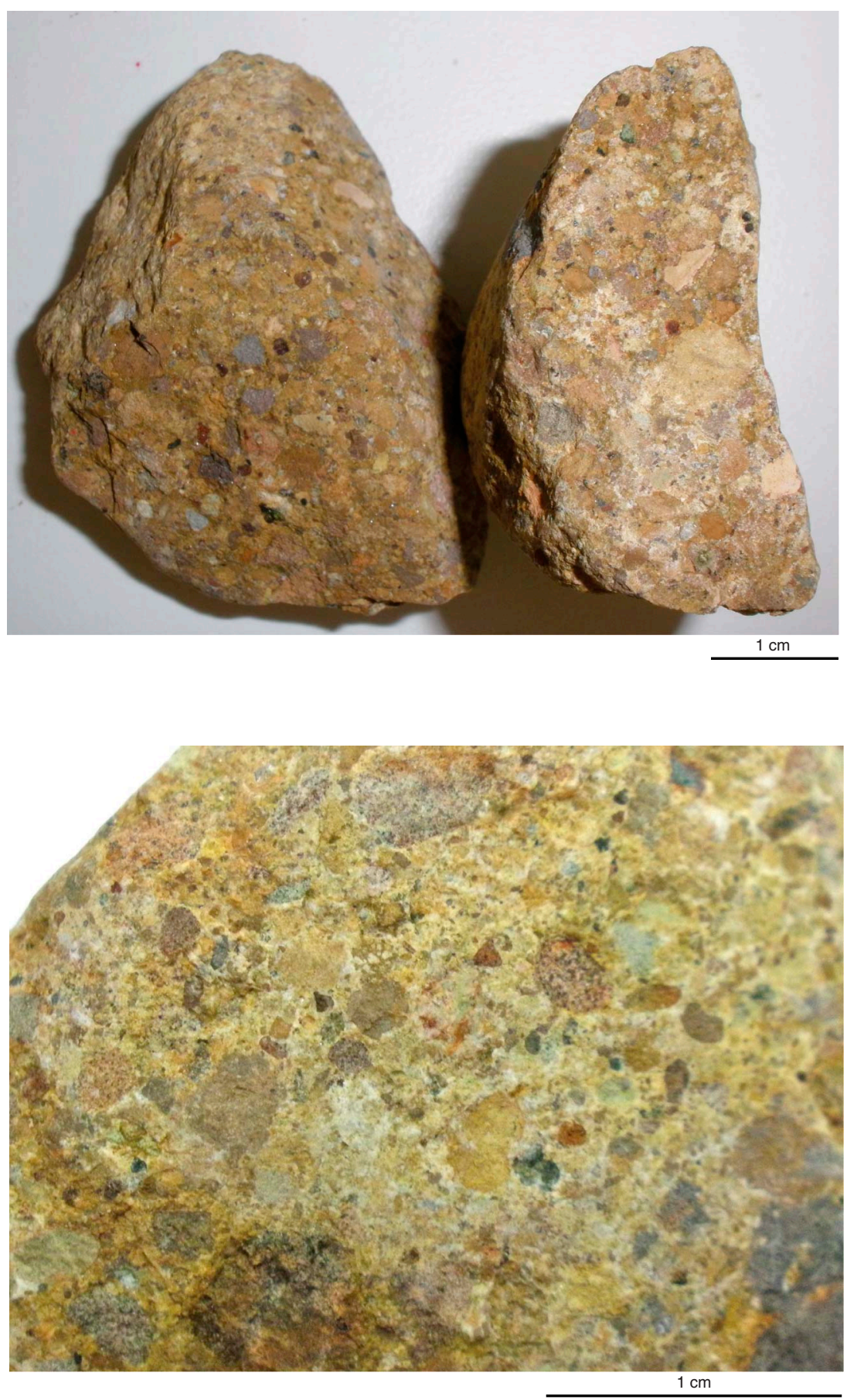
Figure F7. Photographs of massive (structureless) volcaniclastics in stratigraphic Subunit IIIa, Hole U1349A. Interval 324-U1349A-6R-1, 41-56 cm

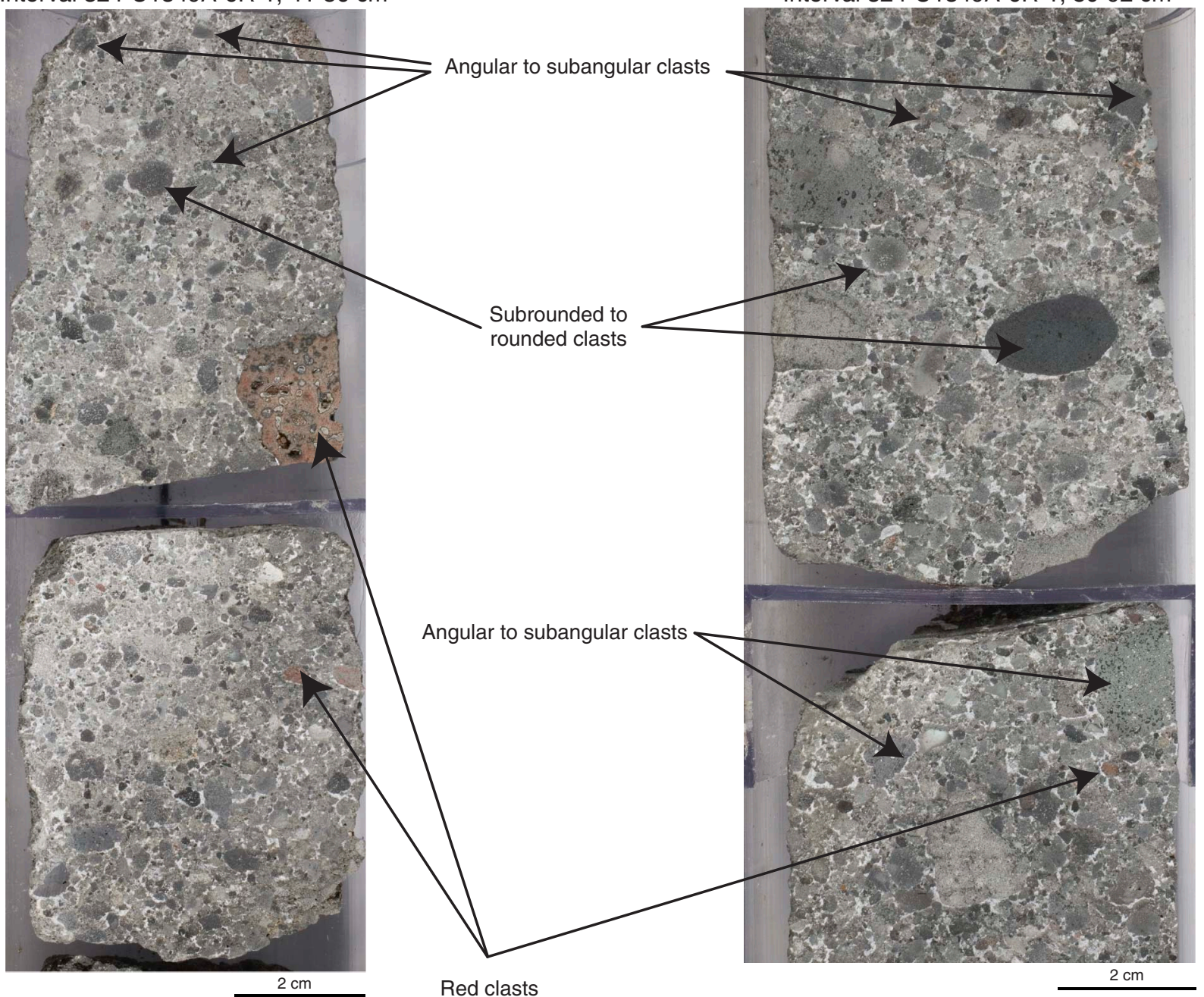
(oxidized basalt) 
Figure F8. A. Core image of cyclic volcanic sand and lapilli-sized volcaniclastic breccia sequence in stratigraphic Subunit IIIa, Hole U1349A. B. Thin section photomicrograph of biogenic fragment within volcaniclastic breccia.

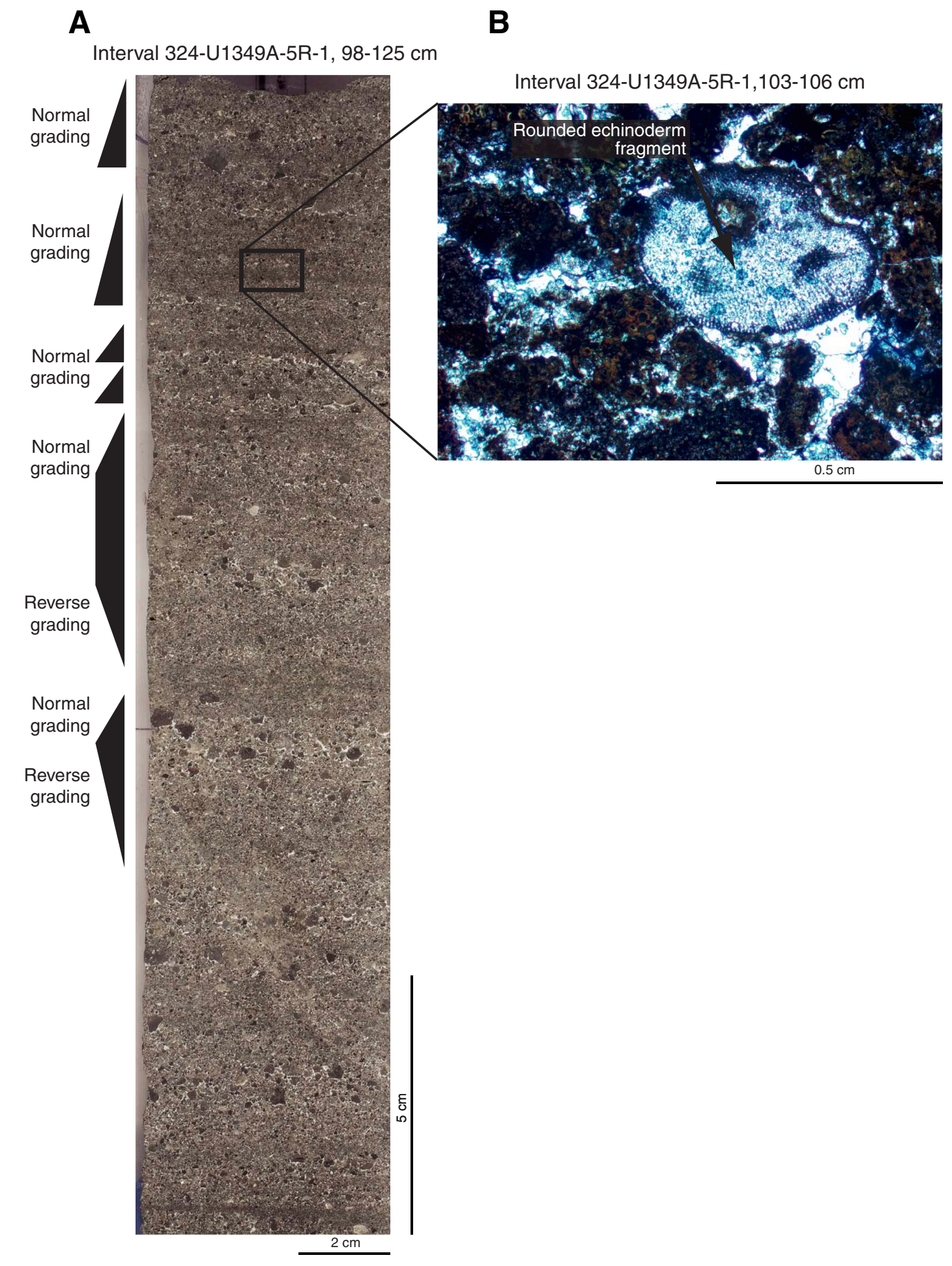


Figure F9. Photograph of structureless volcaniclastic rock with an armored clast, Hole U1349A. View is of the back of the core (round side).

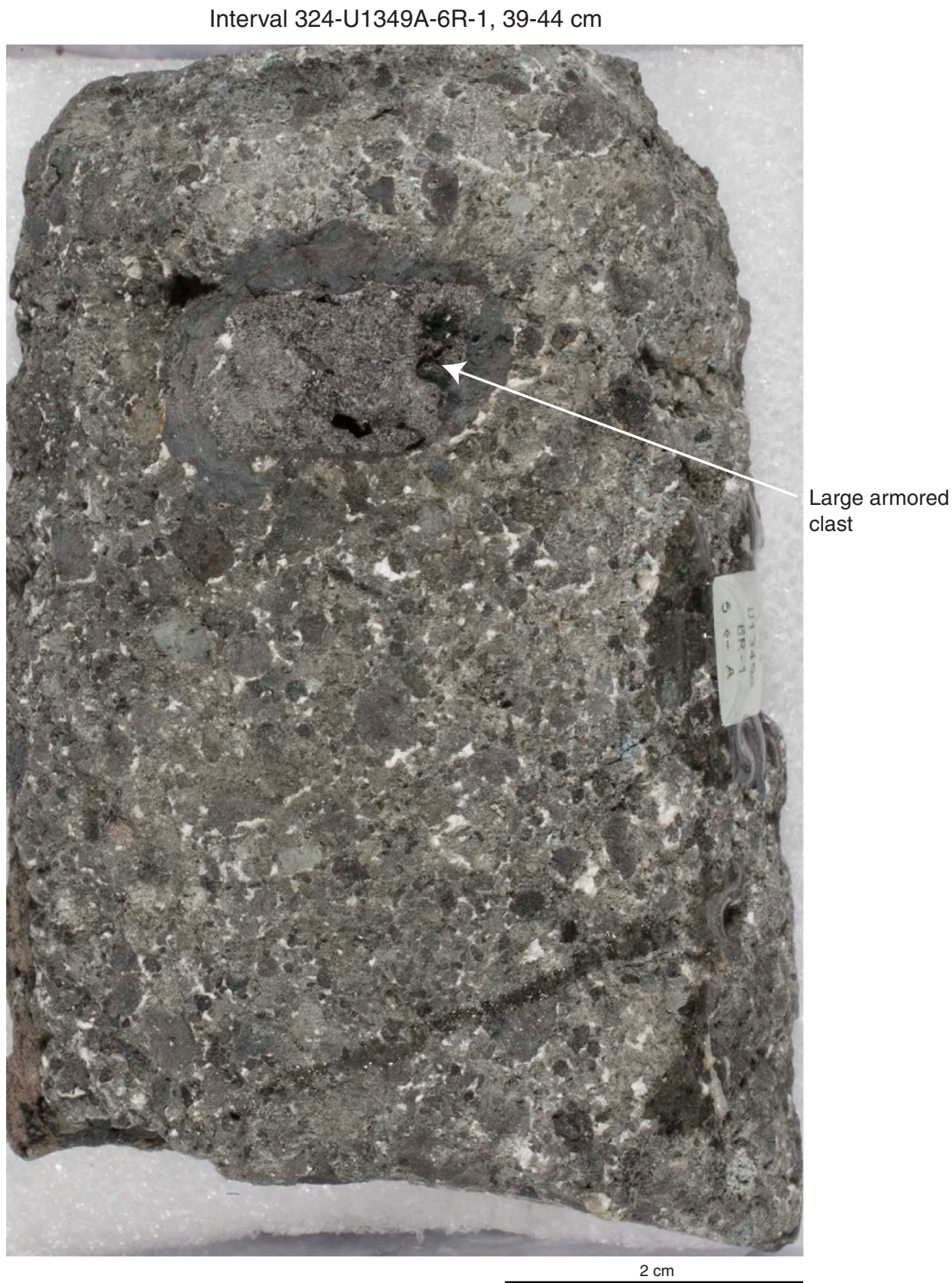


Figure F10. Photographs of oxidized highly weathered horizon at the base of Section 324-U1349A-6R-2, interpreted as a paleosol, Hole U1349A. A. Color gradation from brown-gray material to oxidized horizon at the base. B. Paleosol portion of the core showing reddish clay-rich area, which appears highly oxidized with few subangular weathered volcaniclastic grains. C. Paleosol horizon under low magnification. Note blocky texture and yellow-red coloration.

Interval 324-U1349A-6R-2, 9-26 cm

A

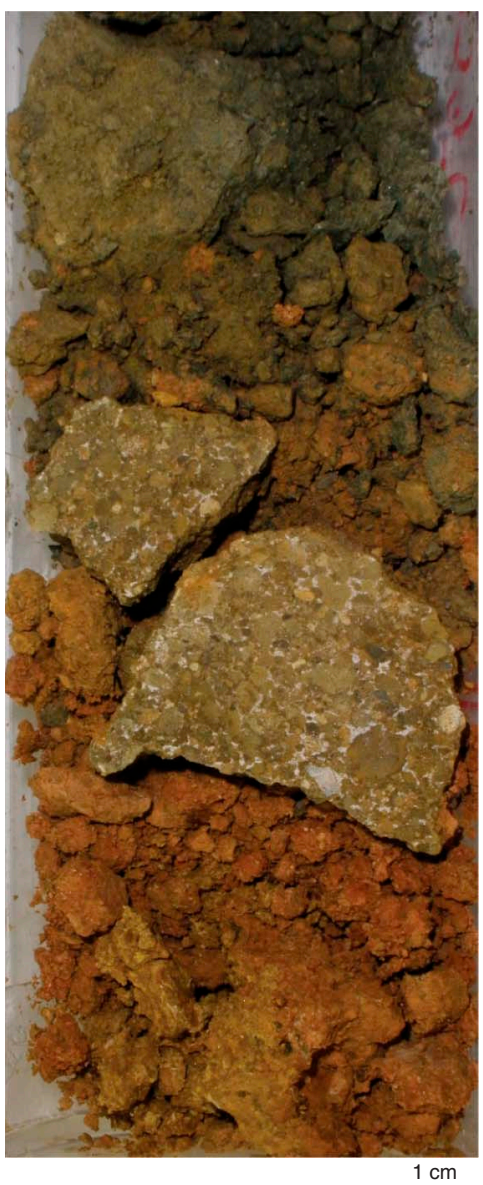

B

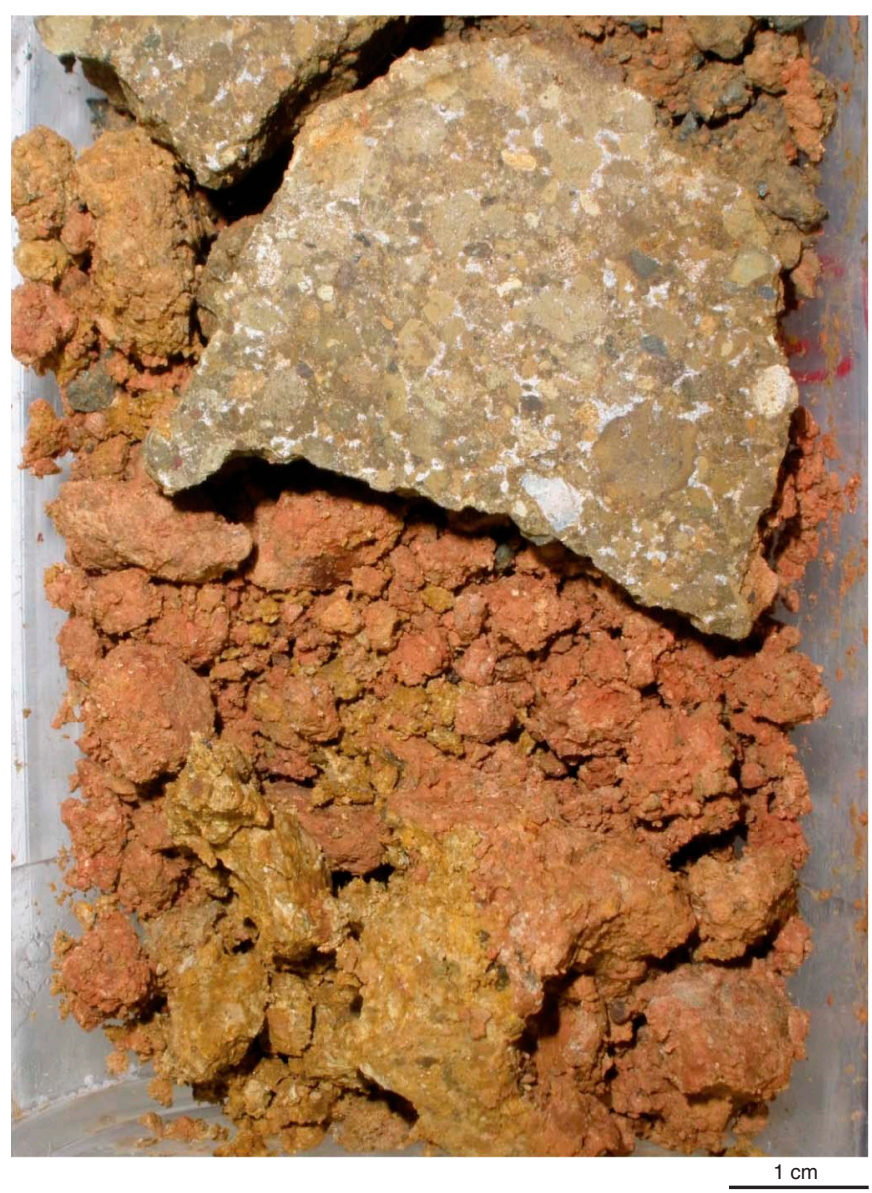

C

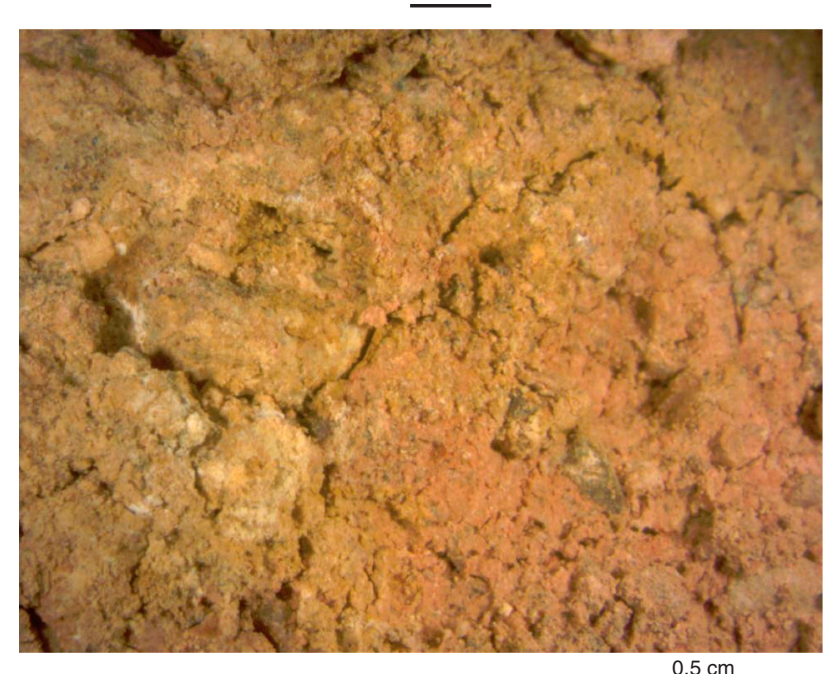


Figure F11. Core image of turbidites and debrite in stratigraphic Subunit IIIb, Hole U1349A. Note large oxidized vesicular clast between 63 and $71 \mathrm{~cm}$.

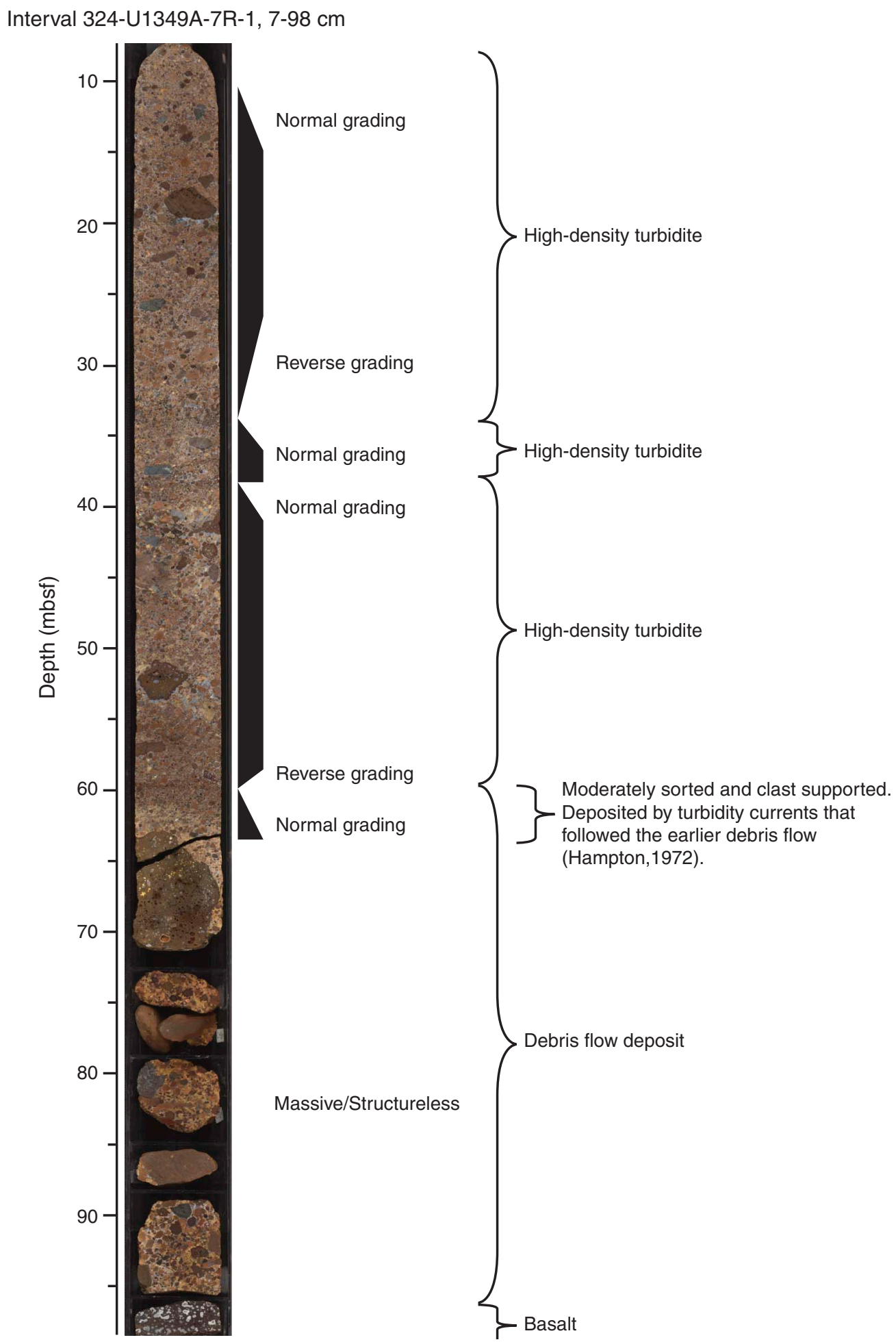


Figure F12. Thin section photomicrographs of components comprising oolitic limestone, Hole U1349A (Section 324-U1349A-9R-1; stratigraphic Subunit IVb). A. Rounded biogenic and volcaniclastic components in limestone. B. Ooid grain (center left) showing concentric laminated outer rim. C. Rounded biogenic grains with cemented outer rims. Biogenic fragment in top left corner may be bryozoan. D. Volcaniclastics including altered glass (brown) and lithic basaltic clast (black). E. Rounded biogenic components including a benthic foraminifer (top center). A, B, D and E are under cross-polarized light; C is under plane-polarized light.

A

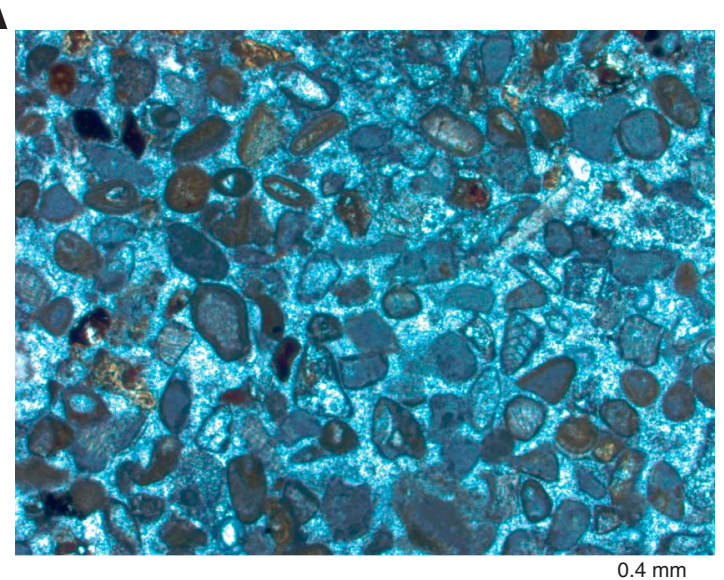

B

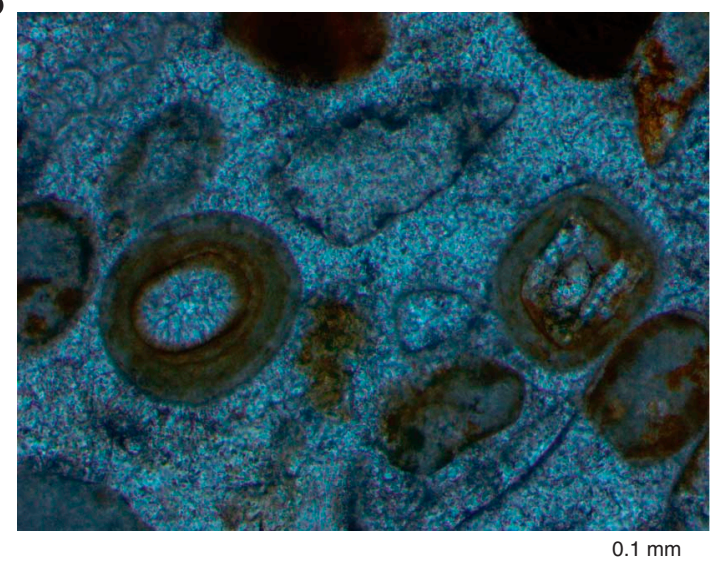

C

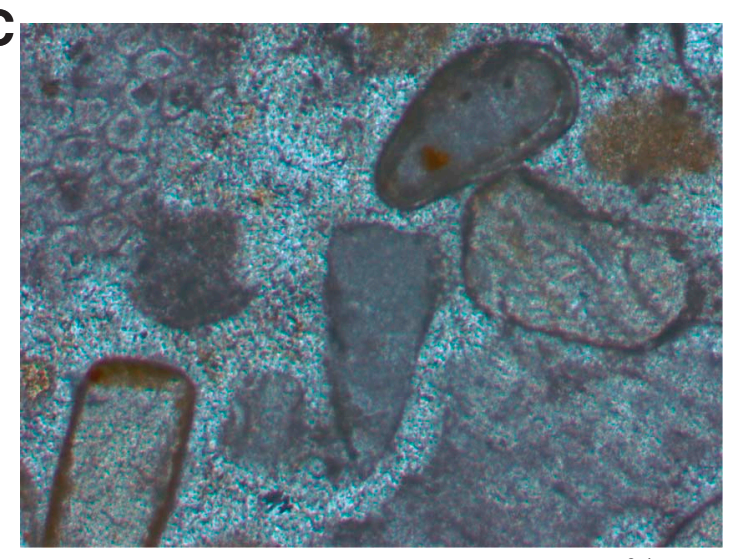

$0.1 \mathrm{~mm}$

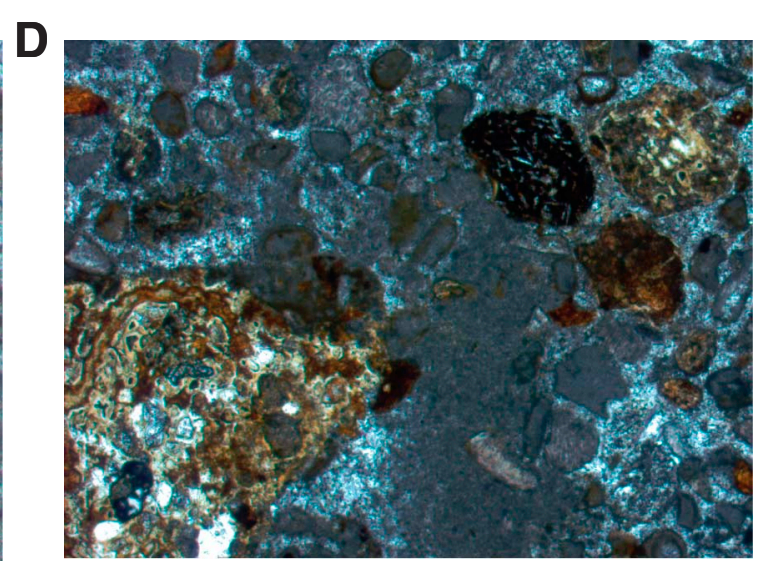

$0.4 \mathrm{~mm}$

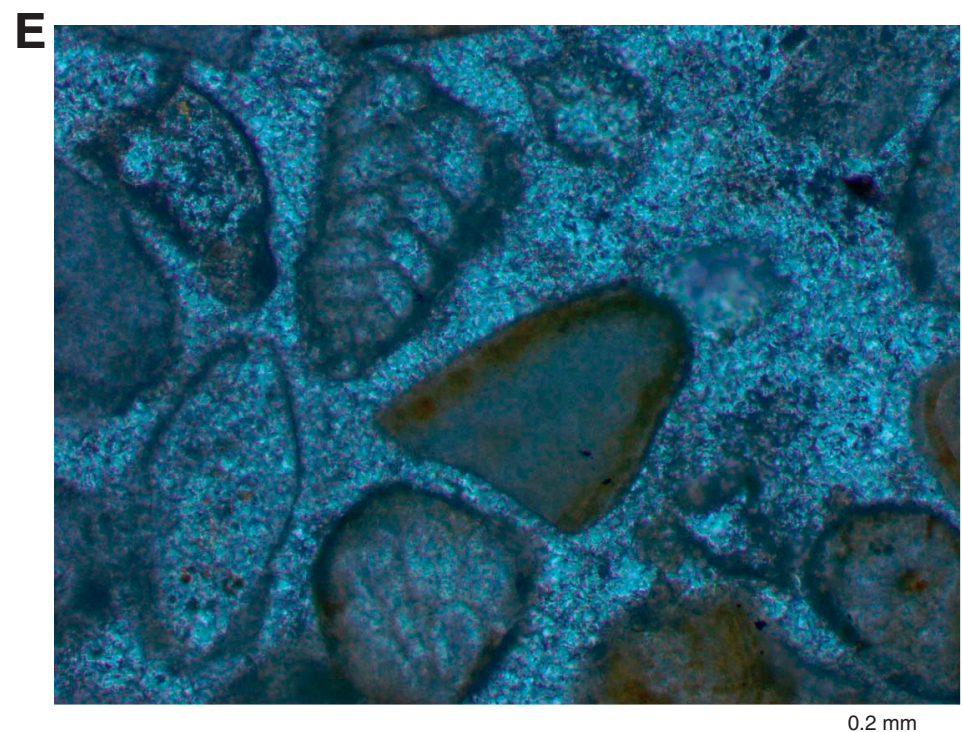


Figure F13. Recovery overview, Hole U1349A. Inflation unit thicknesses are minimal estimates based on the measured upper and lower contacts identified in the core (see Table T5 for data). Stratigraphic unit thicknesses are given based on core description (black) and downhole logging measurements (gray).

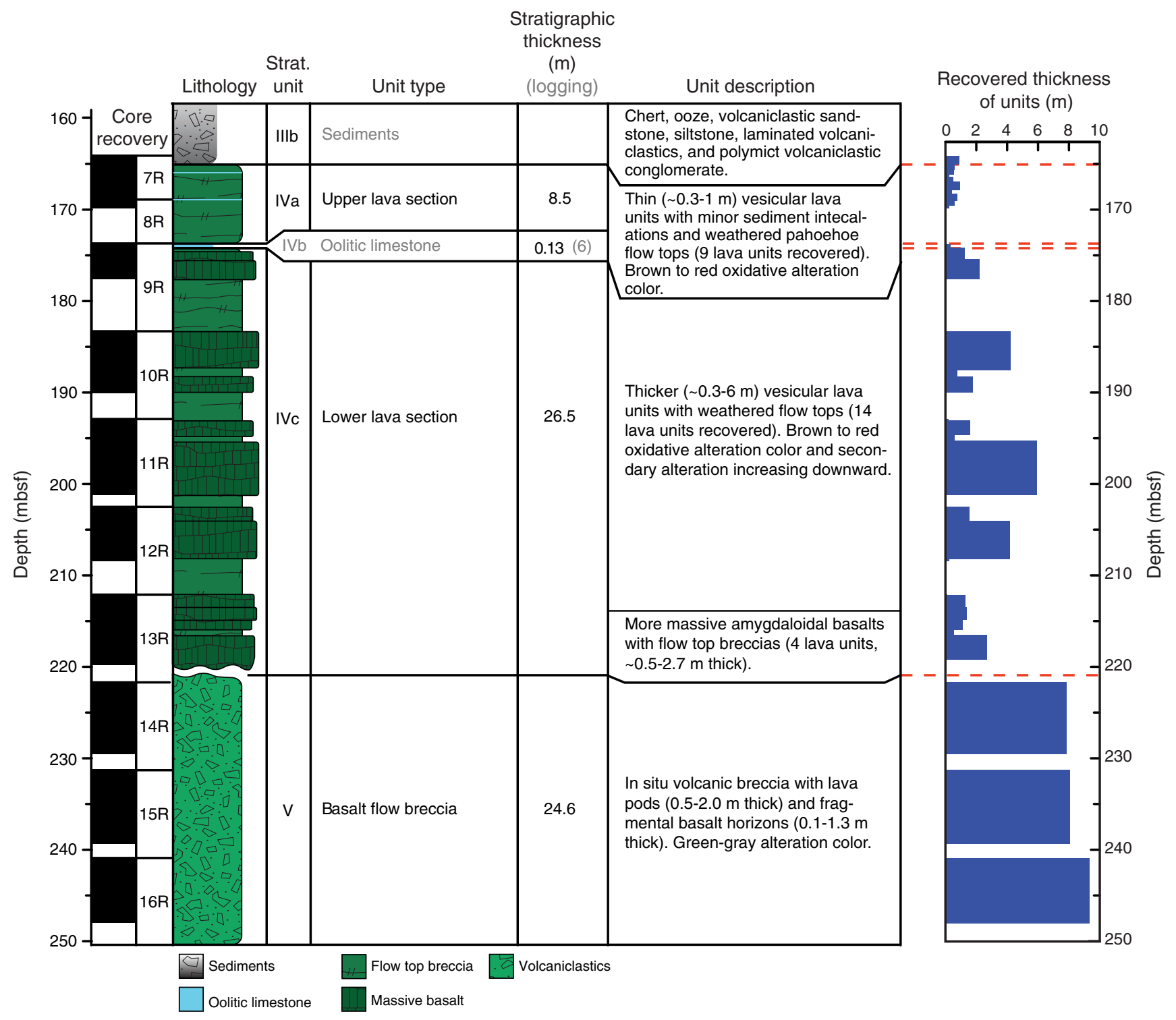


Figure F14. Overview of volcanological and physical parameters for Cores 324-U1349A-7R through 16R, Hole U1349A. NGR = natural gamma radiation, GRA = gamma ray attenuation density, MS = whole round and pointsource magnetic susceptibility (see "Physical properties" for details).

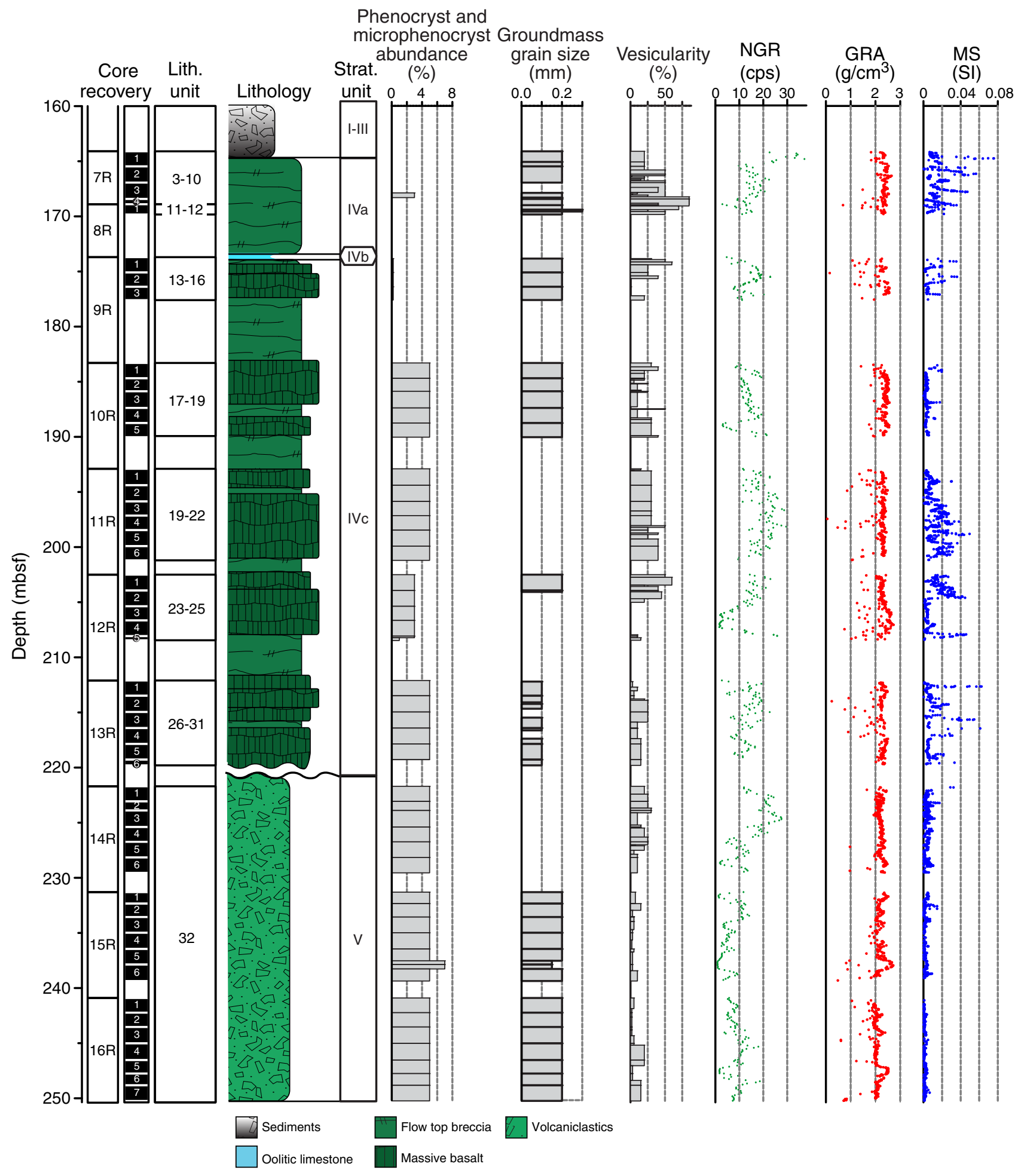


Figure F15. Core section images of Sections (A) 324-U1349A-11R-3, (B) 11R-5, and (C) 11R-4; (D) thin section scan; and (E-G) photomicrographs of lava mixing features in Section 324-U1349A-11R-3, top of Unit IV, Hole U1349A. Thin section scan location of D is indicated by the red box in B. Red box in D indicates photomicrograph location. Photomicrograph location of $\mathrm{G}$ is indicated by red box in E. Field of view for $\mathrm{D}$ is $36 \mathrm{~mm} \times 54$ $\mathrm{mm}$. Width of field of view of F and $\mathrm{G}$ is $\sim 6 \mathrm{~mm}(2.5 \times)$ and $\mathrm{E}$ is $15 \mathrm{~mm}(1.25 \times)$. Plane-polarized transmitted light.

A
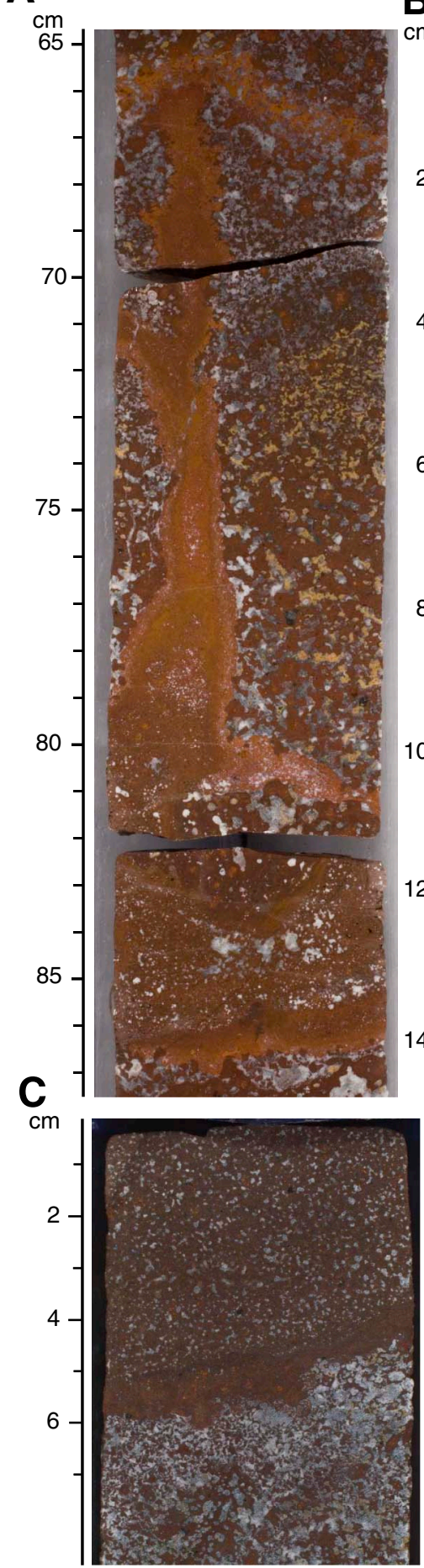

B

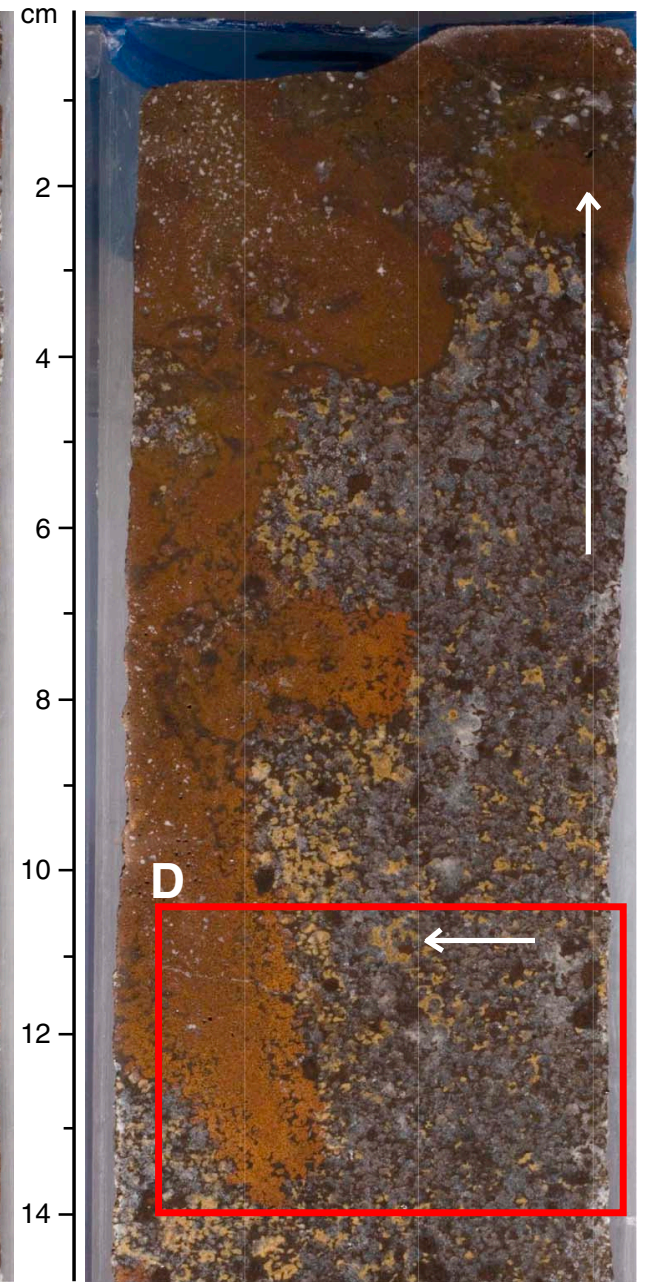

E

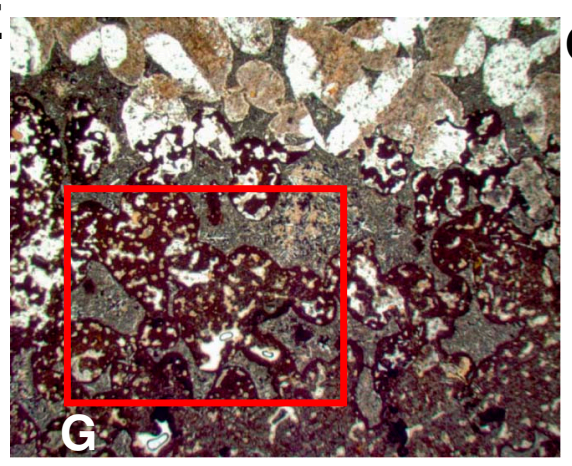

D
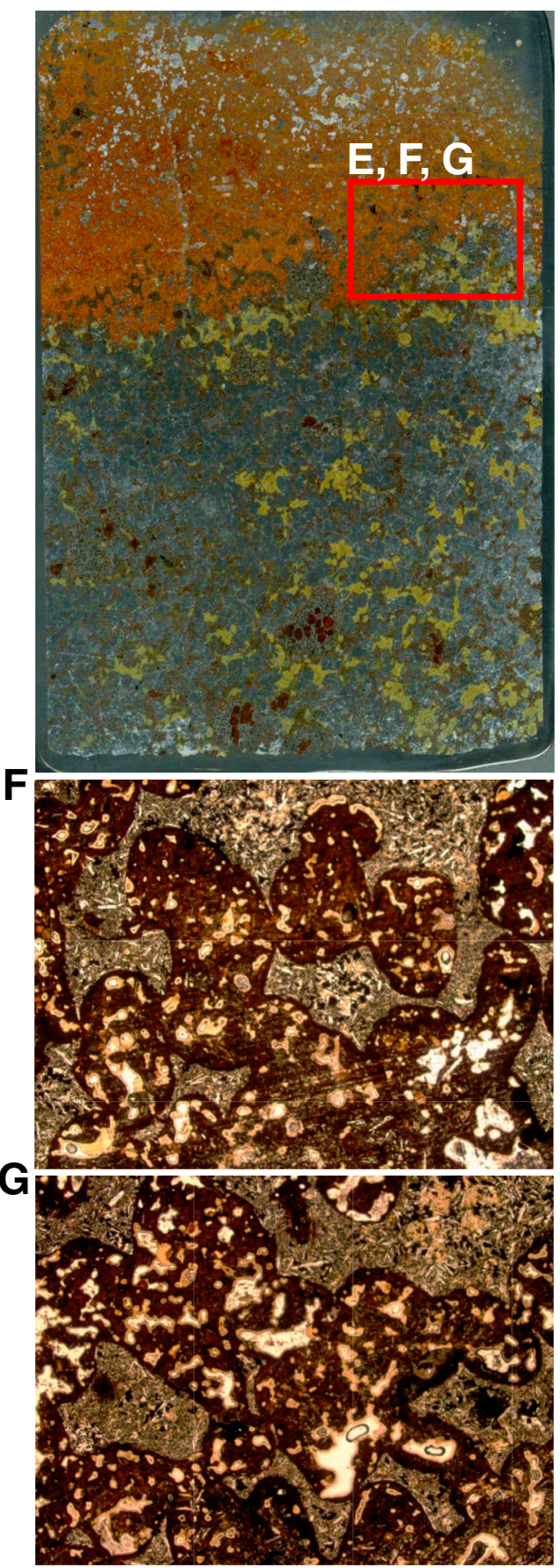
Figure F16. Example of basalt flows, Hole U1349A. A. Lithologic column. Red dashed lines = upper and lower bounds of sections. B. Images of Sections 324-U1349A-13R-2 through 13R-5 annotated with volcanological features of basalt flows from Unit IV. Core recovery $=68 \%$. These core sections exhibit flow top breccia in the upper parts of the flow and massive amygdaloidal basalt in the interiors.

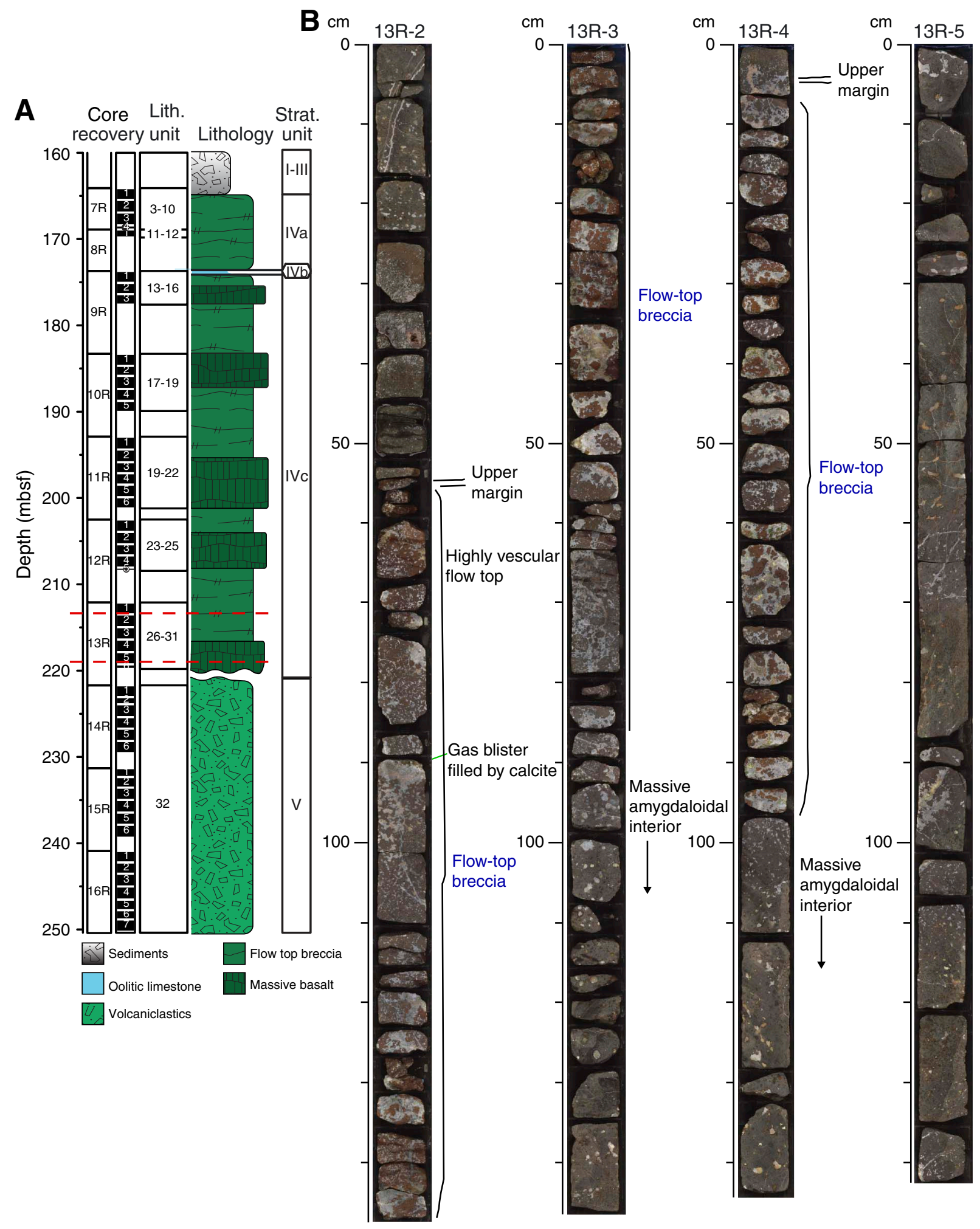


Figure F17. Core section images of (A) Section 324-U1349A-16R-6 and (B) interval 324-U1349A-16R-6, 56-61 $\mathrm{cm}$; (C) thin section scan; and (D, E) photomicrographs of flow breccia in Unit V, Hole U1349A. Thin section scan location of $\mathrm{C}$ is indicated by the red box in $\mathrm{B}$. Red boxes in $\mathrm{C}$ indicate photomicrograph locations. Width of field of view for D is $\sim 15 \mathrm{~mm}(1.25 \times)$. Width of field of view for E is $\sim 10 \mathrm{~mm}$. Plane-polarized light.

A

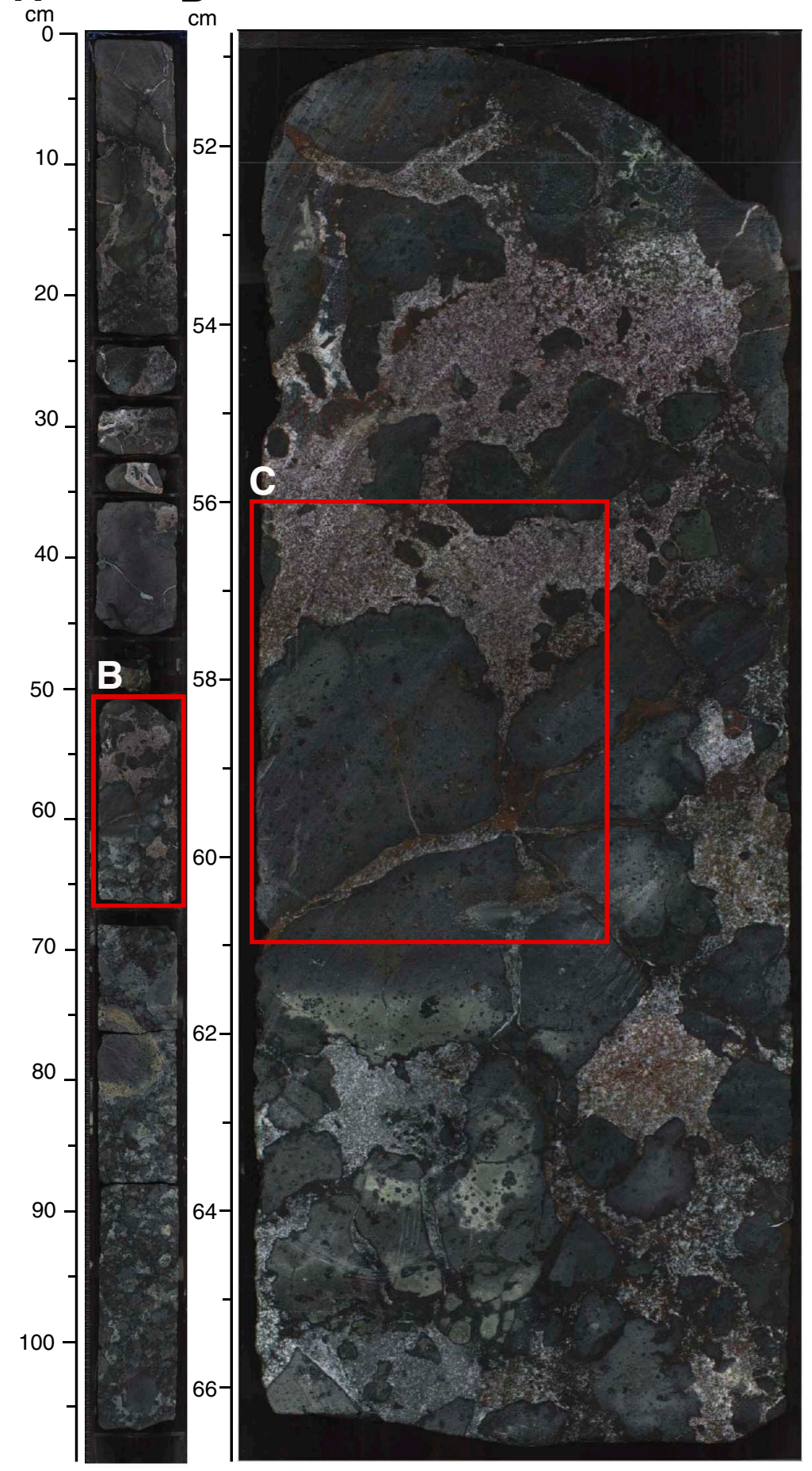

C

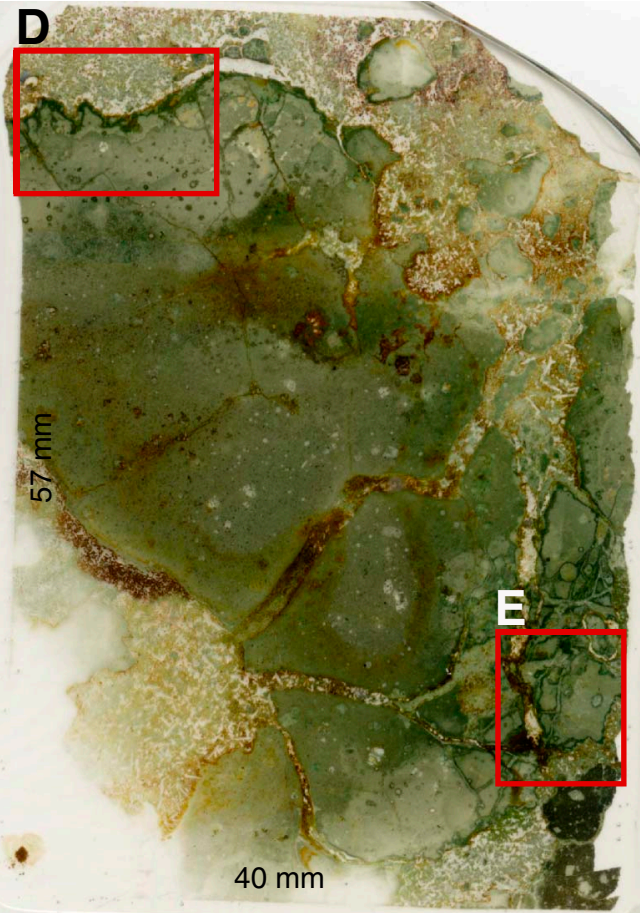

D

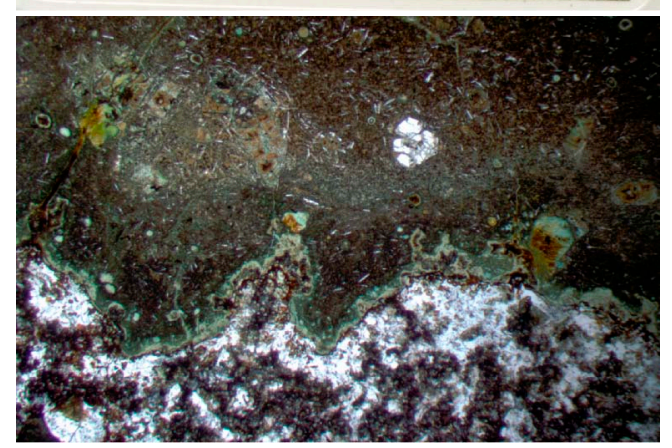

E

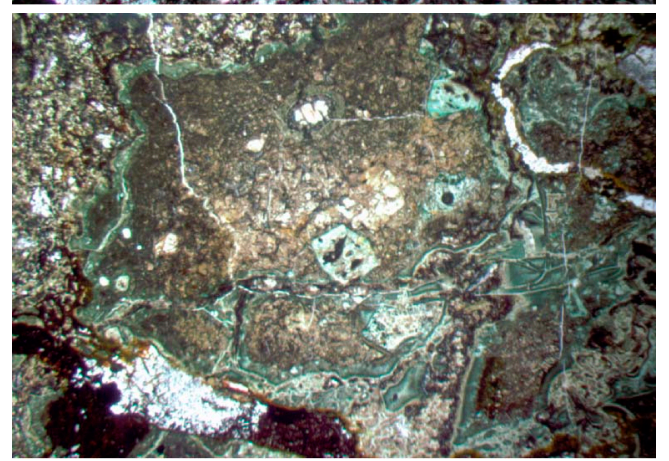


Figure F18. Core section images of (A) Section 324-U1349A-16R-6 and (B) interval 324-U1349A-16R-6, 70-88 $\mathrm{cm}$; (C) thin section scan; and (D, E) photomicrographs of flow breccia in Unit V, Hole U1349A. Thin section scan location of $\mathrm{C}$ is indicated by red box in $\mathrm{B}$. Red boxes in $\mathrm{C}$ indicate photomicrograph locations. Width of field of view for $\mathrm{D}$ is $\sim 10 \mathrm{~mm}(1.25 \times)$. Width of field of view for $\mathrm{E}$ is $\sim 6 \mathrm{~mm}(2.5 \times)$. Plane-polarized light.

A

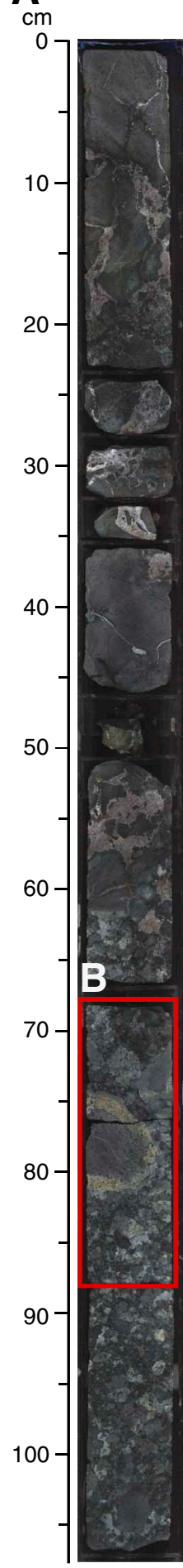

B

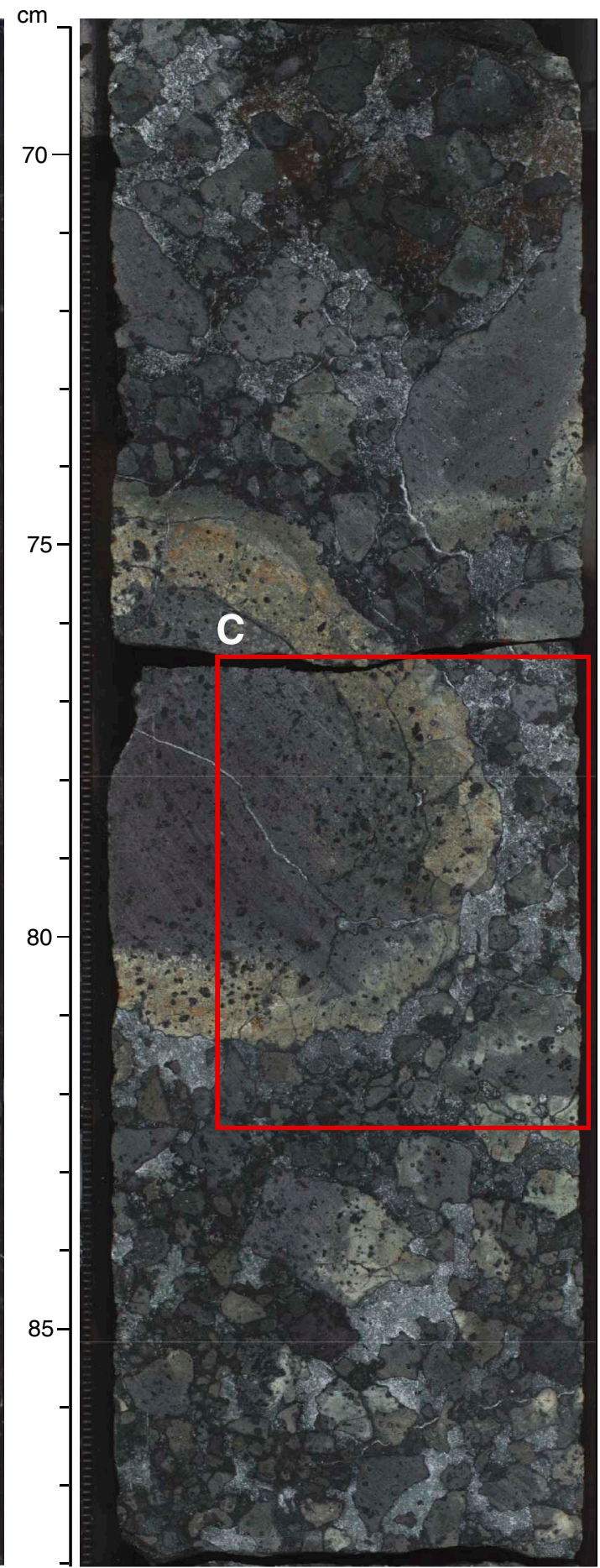

C

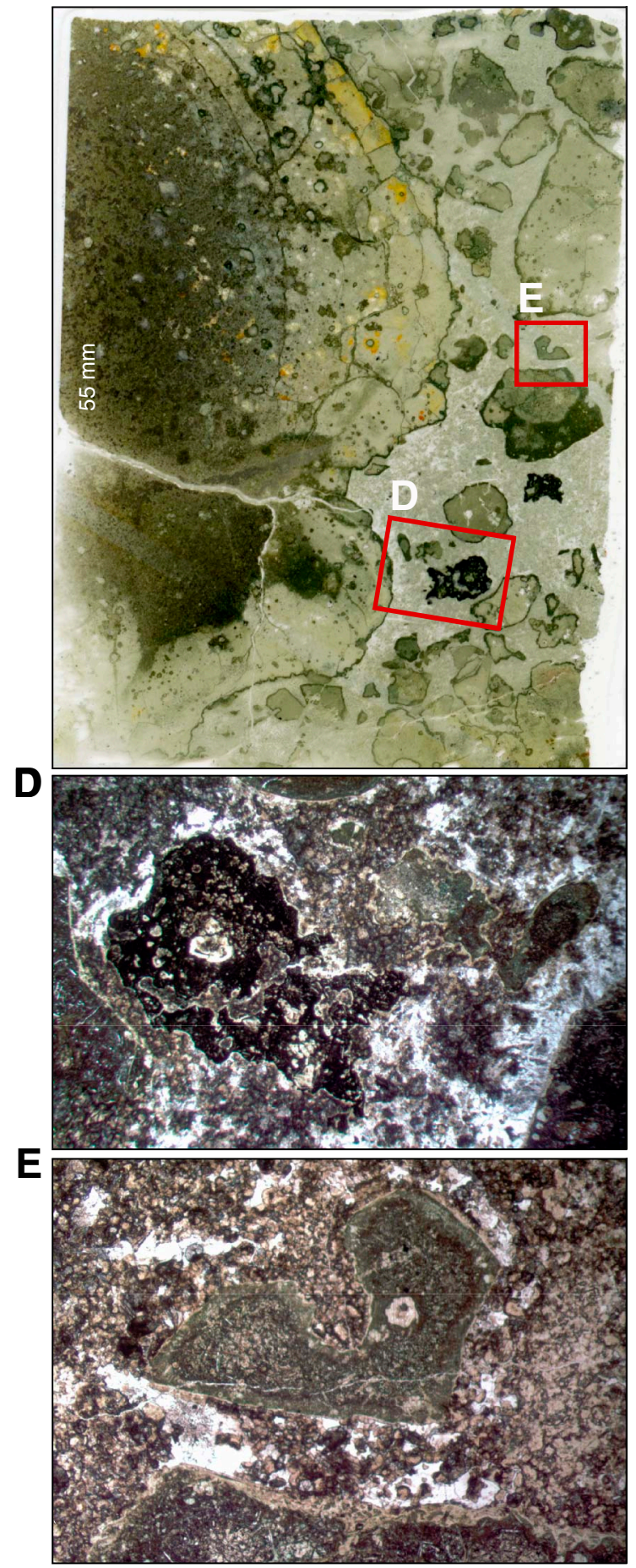


Figure F19. Plot of calculated vesicle contents in basalts from Site U1349 as a function of pressure and water depth of eruption (modified after Wallace, 1998). Gray rectangle = vesicularity range. Degassing curves with different proportions of $\mathrm{H}_{2} \mathrm{O}$ and $\mathrm{CO}_{2}$ dissolved in the melt (fig. 11 in Wallace, 1998) show calculated vesicularity of each melt as a function of eruption pressure (water depth). The diagram is useful to bracket possible eruption depth for highly vesicular basalts. Assuming low $\mathrm{H}_{2} \mathrm{O}(<0.4 \mathrm{wt} \%)$ contents in MORB-like melts and high vesicle abundance (up to $75 \mathrm{vol} \%$ ), one can conclude that the possible range of eruption pressures relevant for Site U1349 basalts was $<15$ bar $(<150 \mathrm{mbsl})$.

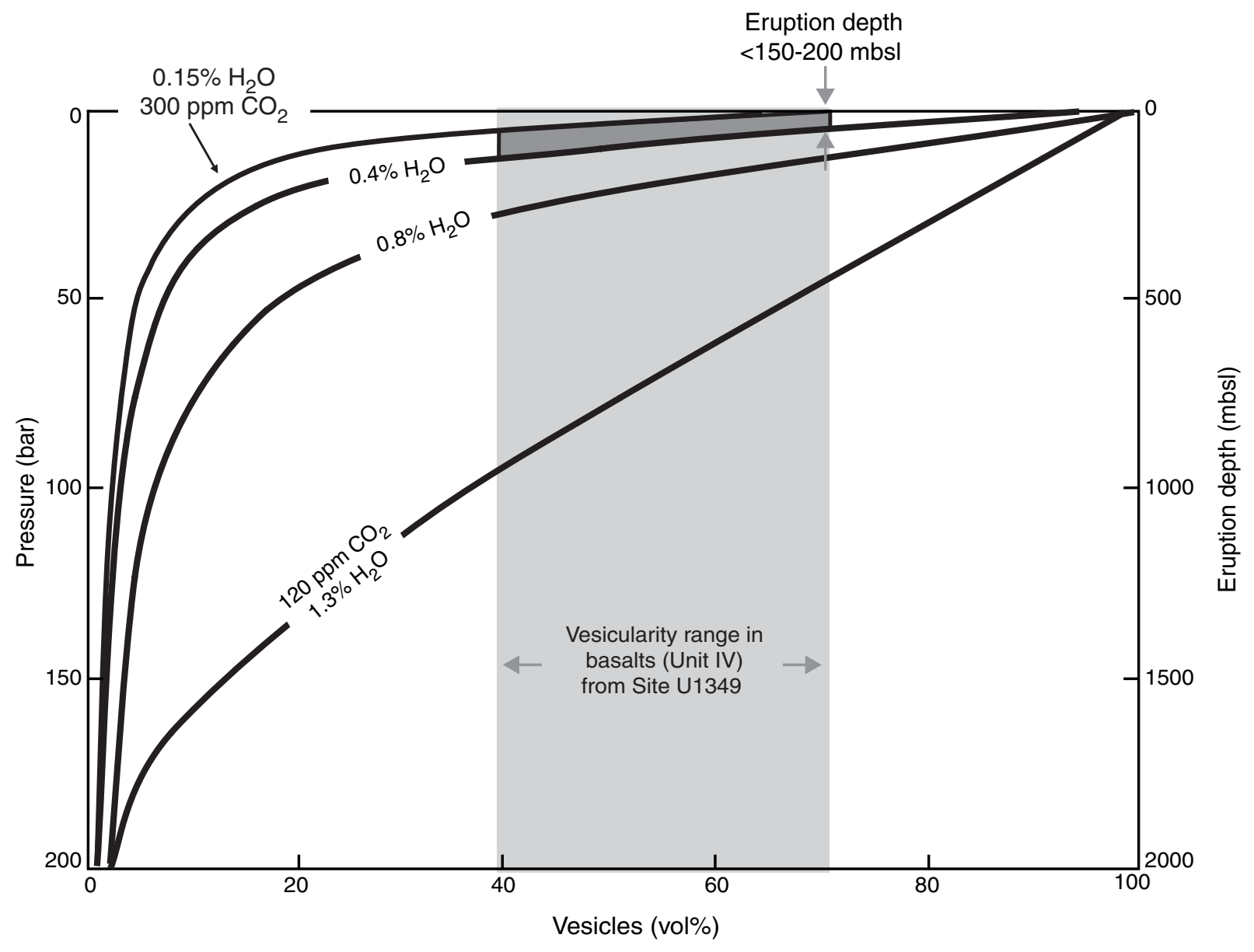


Figure F20. Depth profiles of modal abundances of olivine and pyroxene occurring as either phenocrysts or microphenocrysts, Hole U1349A. Red dashed lines = recovered depths of the unit boundaries.

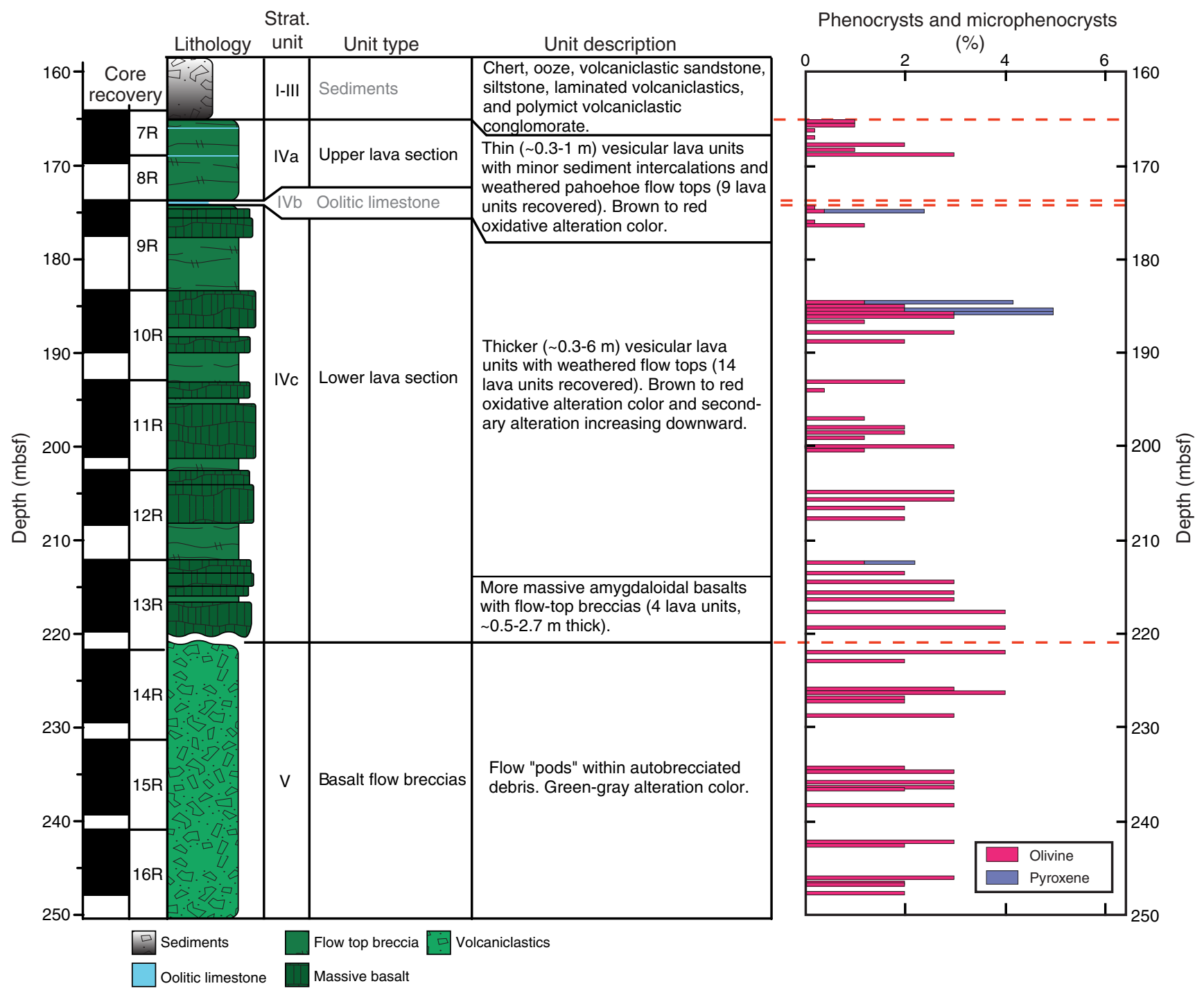


Figure F21. Photomicrographs of igneous features of sedimentary rocks in Unit III, Hole U1349A. A, B. Probable ferroandesite clast in conglomerate with abundant feldspar and skeletal titanomagnetite (Thin Section 205; Sample 324-U1349A-7R-1, 65-67 cm). C, D. Small chip of probable ferroandesite in conglomerate, with trachytic texture in feldspar and abundant skeletal titanomagnetite (Thin Section 204; Sample 324U1349A-7R-1, 40-46 cm). E, F. Palagonitized hyaloclastite sandstone with (E) angular chips of both glass (orange) and spherulitic basalt (dark brown) and (F) possible lithic chips of more crystalline basalt (Thin Section 206; Sample 324-U1349A-7R-1, 112--115 cm). A, C, E, and F are under transmitted light; B and D are under reflected light.
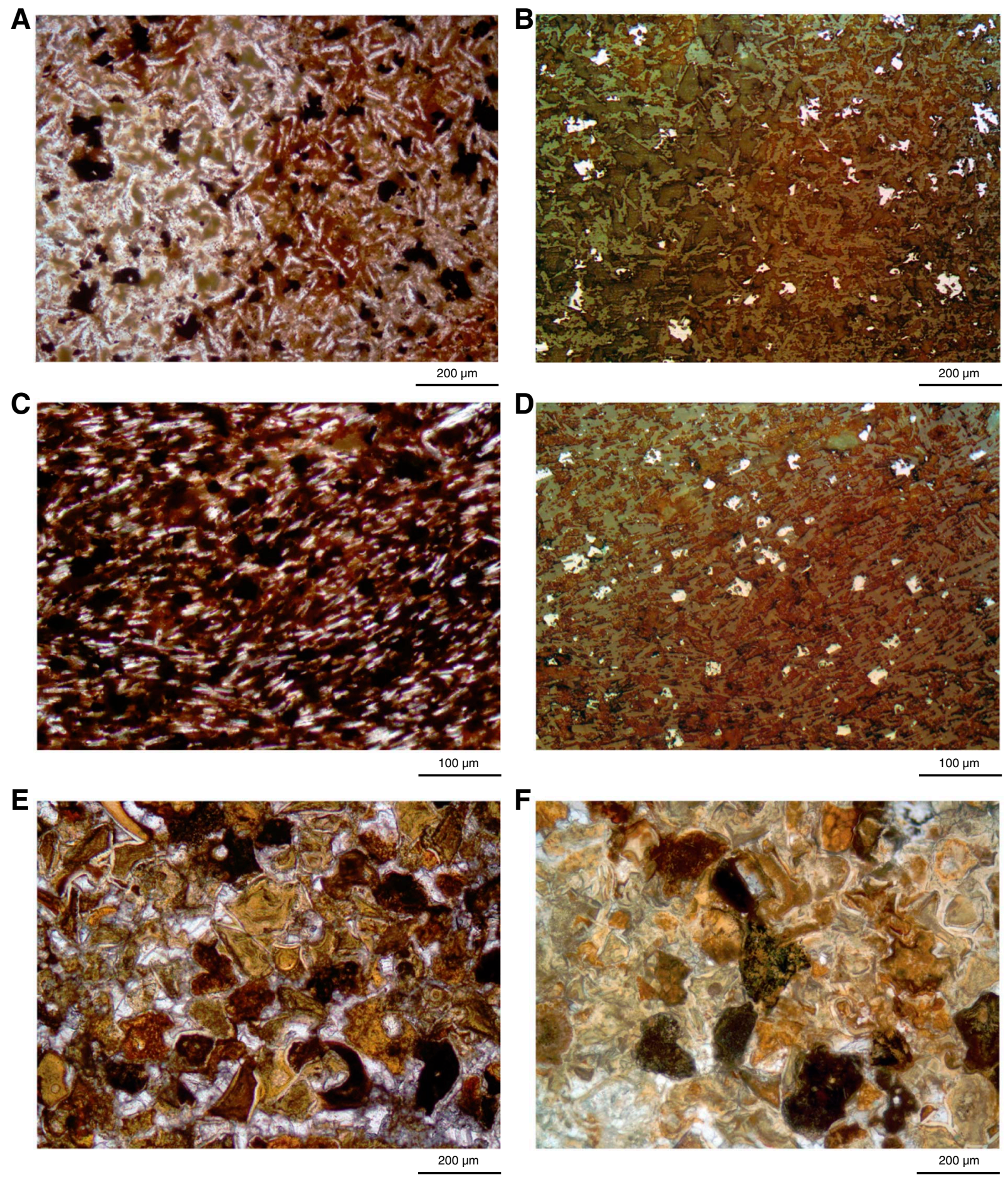
Figure F22. Photomicrographs of variations in crystal morphology and grain size across a highly vesiculated basalt in Subunit IVa, Hole U1349A (Thin Section 209; Sample 324-U1349A-7R-3, 78-81 cm). A. Coalesced circular spherulites $\sim 50 \mu \mathrm{m}$ in diameter are strongly oxidized to reddish brown and lie between large vesicles lined with clays and filled with calcite. Tiny plagioclase microlites are in the material. B. Zone of intersecting sheaf spherulites altered to brown clays, with irregular bundles and individual crystals of plagioclase. The vesicles are filled with calcite. C. Zone of radiating acicular plagioclases having larger bundles of intergrown plagioclase and altered clinopyroxene (yellow) with dendritic overgrowths. D. Coarsest grained part of the thin section, in which plagioclase-clinopyroxene intergrowths are starting to crystallize into networks. An altered clinopyroxene microphenocryst is at the lower right, and a large pair of altered olivine crystals, both replaced by clays and iron oxyhydroxides, is on the left. Small crystals of Cr spinel can be seen near and in the olivine.
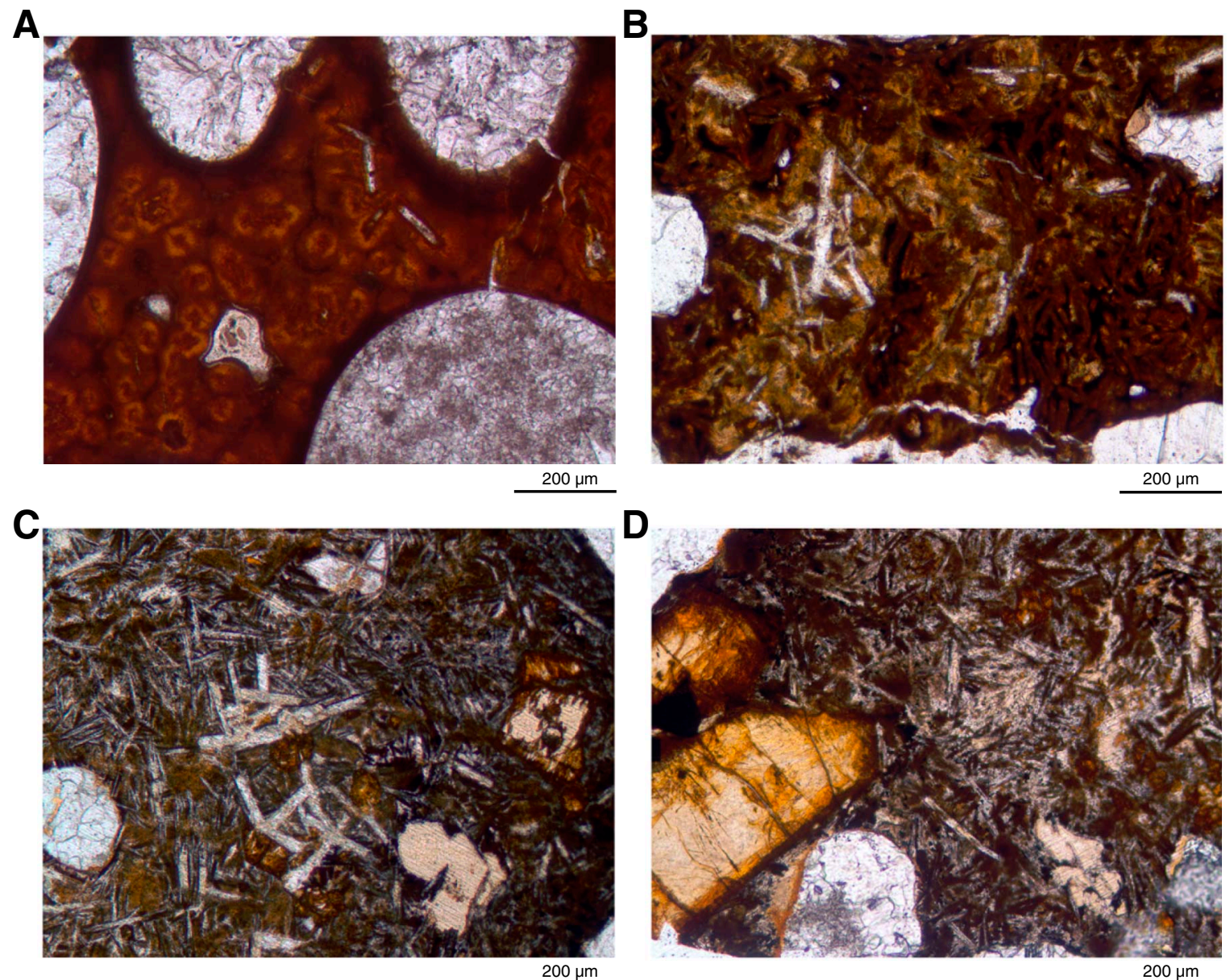
Figure F23. Photomicrographs of olivine and spinel phenocrysts in Unit IV, Hole U1349A. A. Olivine replaced by clays, hematite, and iron oxyhydroxides (Thin Section 209; Sample 324-U1349A-7R-3, 39-43 cm). B. Cluster of euhedral olivine crystals, now altered, and former cracks prominently outlined by secondary minerals, as in A. A large brown spinel lies between two of the olivine crystals (Thin Section 207; Sample 324U1349A-7R-2, 29-33 cm). C. Cluster of spinel crystals within an altered olivine. Olivine is replaced by calcite that is dusted with hematite, but spinel is largely unaltered. Some reticulate alteration can be seen on the uppermost spinel (Thin Section 220; Sample 324-U1349A-10R-4, 85-89 cm). D. Usual altered olivine containing isolated (bright, euhedral) crystals of Cr spinel. Largest crystal has a round former melt inclusion within it (Thin Section 219; Sample 324-U1349A-10R-2, 10-12 cm). A and B are under transmitted light; C and D are under reflected light.
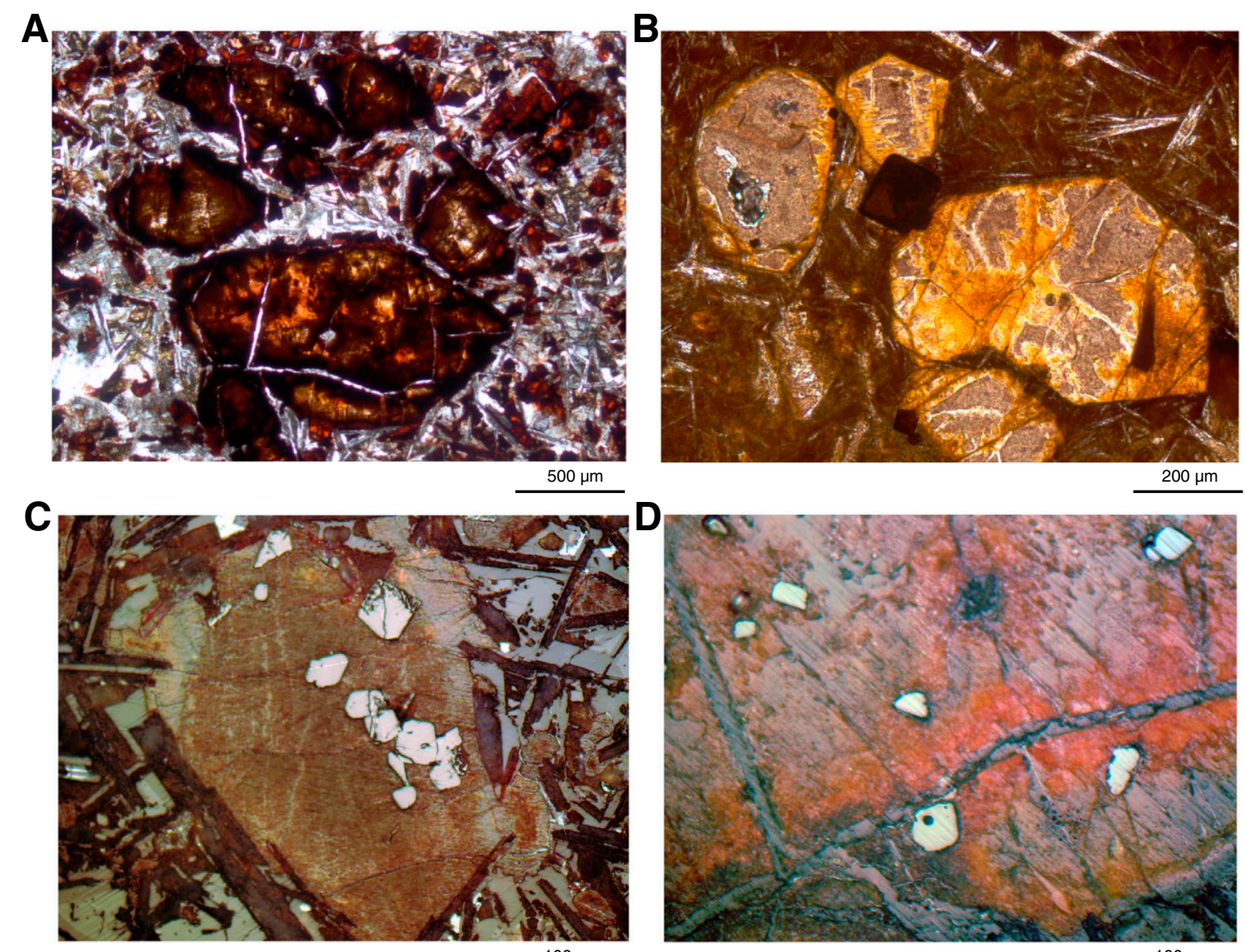

$100 \mu \mathrm{m}$

$100 \mu \mathrm{m}$ 
Figure F24. Photomicrographs of portions of scans of thin sections in Unit IV with ophimottled texture, Hole U1349A. A-C. Thin Section 218 (Sample 324-U1349A-9R-3, 3-9 cm). D, E. Thin Section 219 (Sample 324U1349A-10R-2, 10-12 cm). Sectors of tabular white plagioclase are intergrown ophitically with pale green clinopyroxene and set off by a finer grained groundmass containing abundant specks of hematite (reddish brown). Intergrowths are coarser in D than in A. In A, a semicircular domain with less groundmass hematite is set off by the yellow clays replacing former intersertal glassy regions of the thin section. An altered olivine containing spinel is at the lower right.

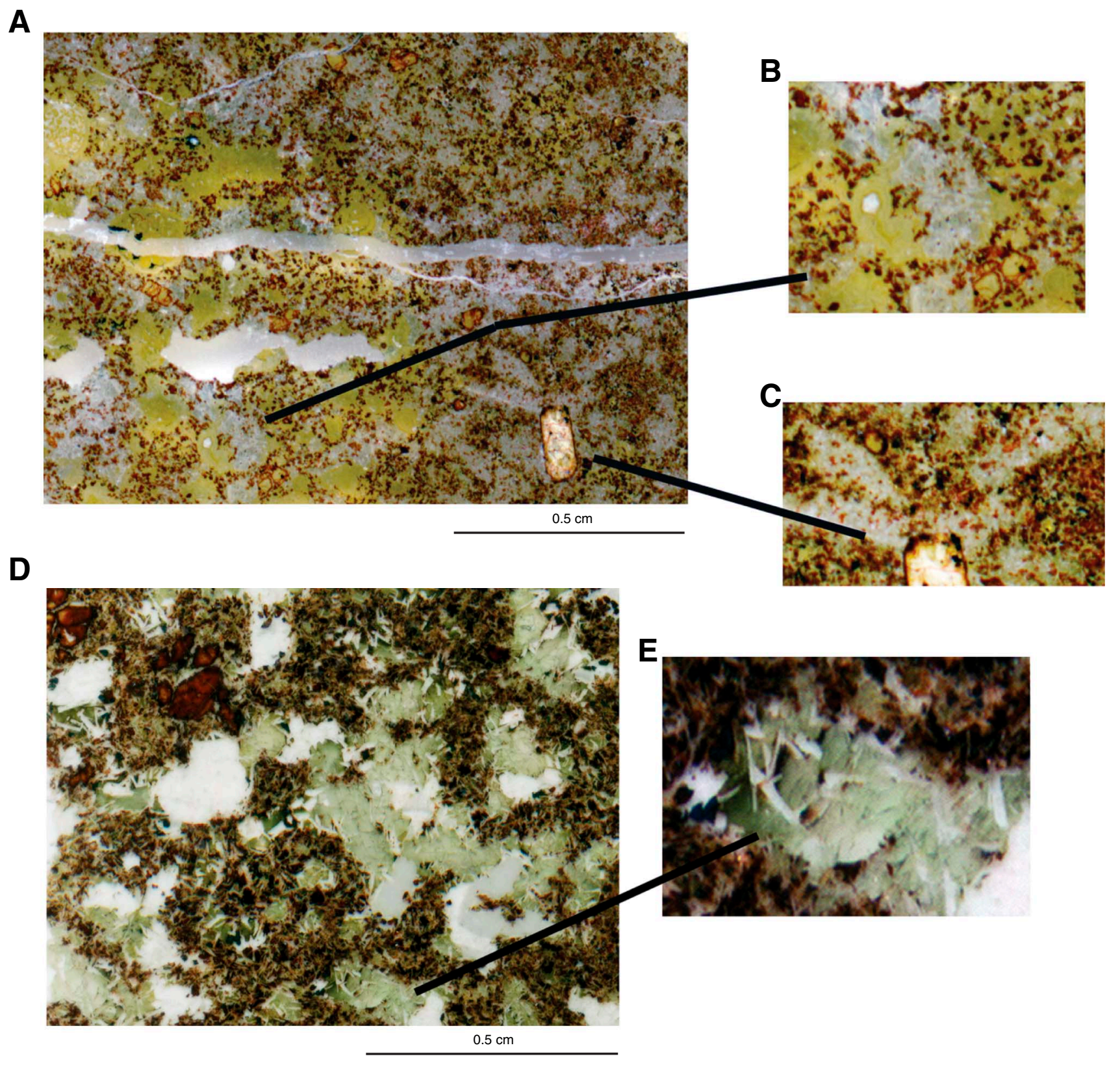


Figure F25. A-F. Photomicrographs of ophimottle textures, Hole U1349A (Thin Section 219; Sample 324U1349A-10R-2, 10-12 cm). Each intergrowth has clinopyroxene with uniform extinction enclosing clusters of elongate, smaller, tabular plagioclase and irregular outlines. The intergrowth in D and $\mathrm{E}$ has large crystals of titanomagnetite at its rim, appearing bright in the reflective light of F, and associated with smaller rimming plagioclase and clinopyroxene crystals than in the center of the intergrowth. A and $\mathrm{C}$ are under transmitted light; B, D, and E are under cross-polarized light; F is under reflected light.

A

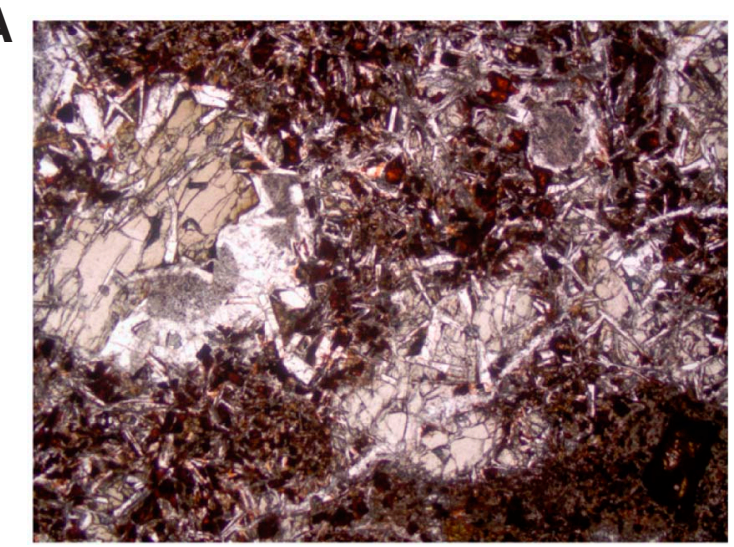

C
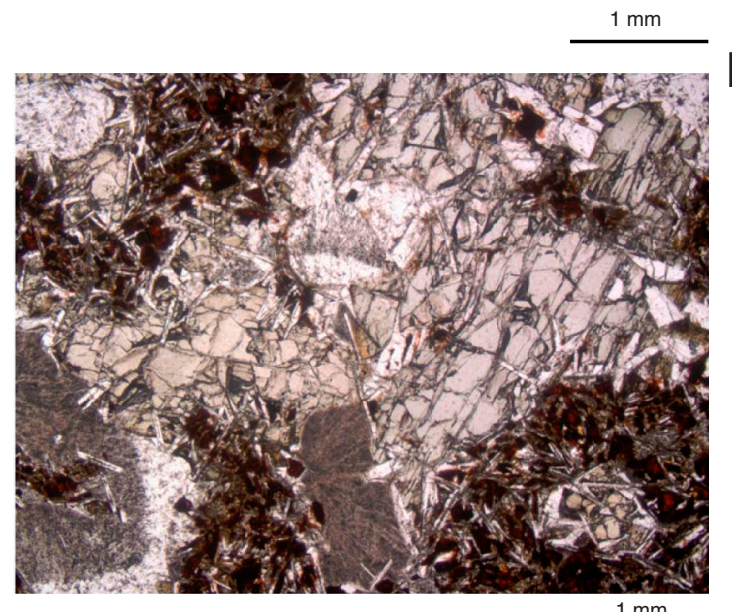

E

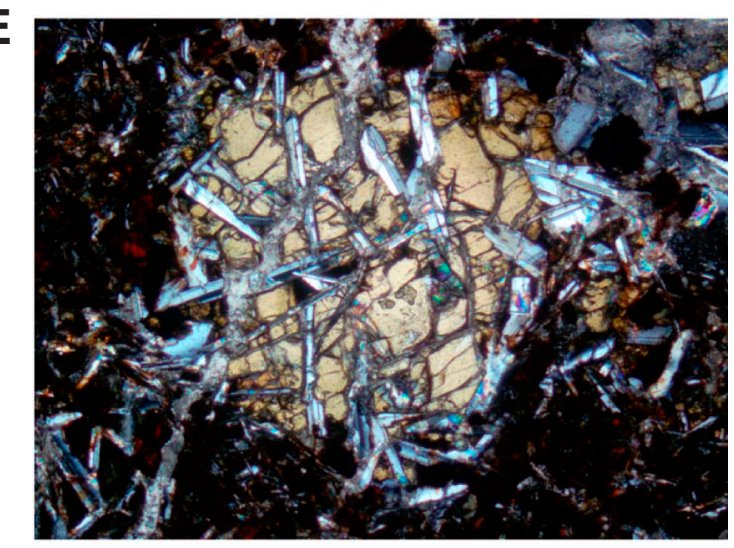

B

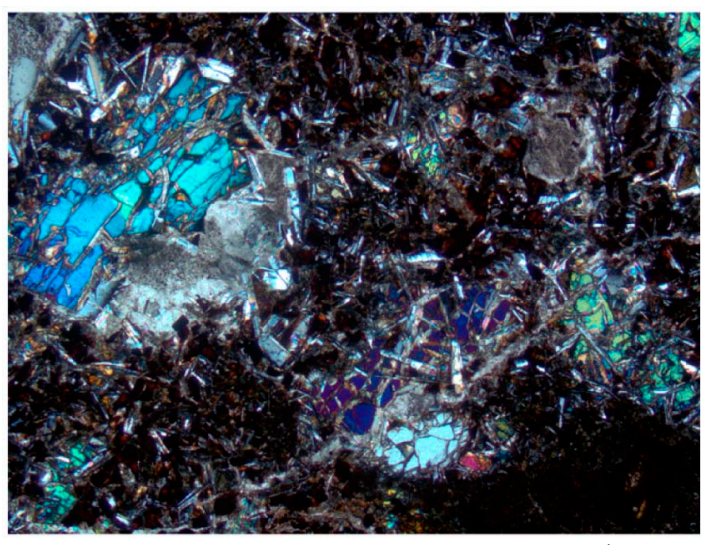

D

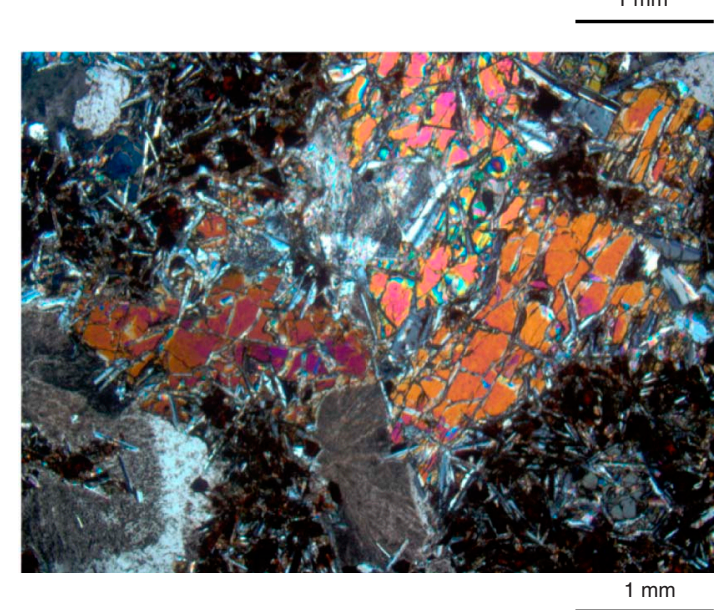

F

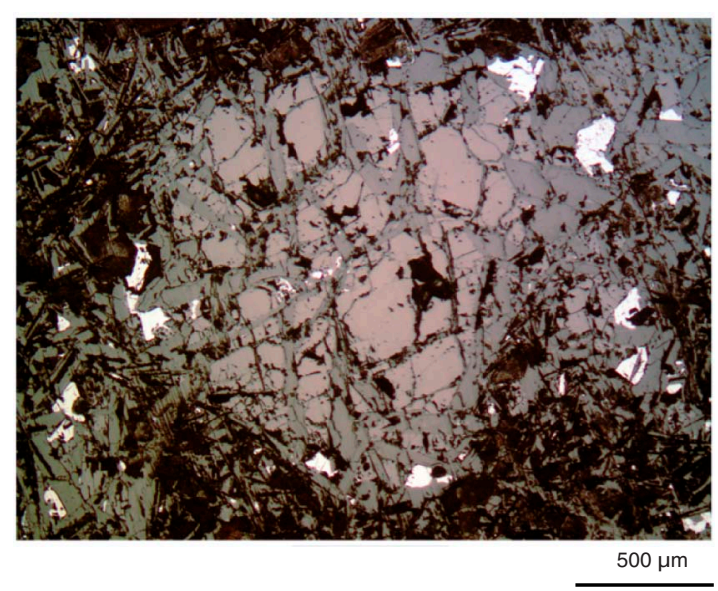


Figure F26. A-D. Photomicrographs of oxy-exsolution in coarse titanomagnetite at the rims of plagioclase-clinopyroxene ophimottles, Hole U1349A (Thin Section 219; Sample 324-U1349A-10R-2, 10-12 cm). In A and $\mathrm{B}$, the titanomagnetite has skeletal morphologies with euhedral outlines. B and C show the same oxide mineral. The exsolution can be made out in air using lower magnification, as in B, but stands out in reflected light. Four different oxide minerals are present in both $\mathrm{C}$ and $\mathrm{D}$. Exsolution lamellae are sharper and minerals have higher contrast in D, which is also more altered. Lamellae are raveled at the edges and evidently transformed to iron oxyhydroxides or hematite, which is very fine grained, not polished, embedded in the adjacent clinopyroxene, and only evident as internal reflections. Reflected light. C and D are with oil immersion.
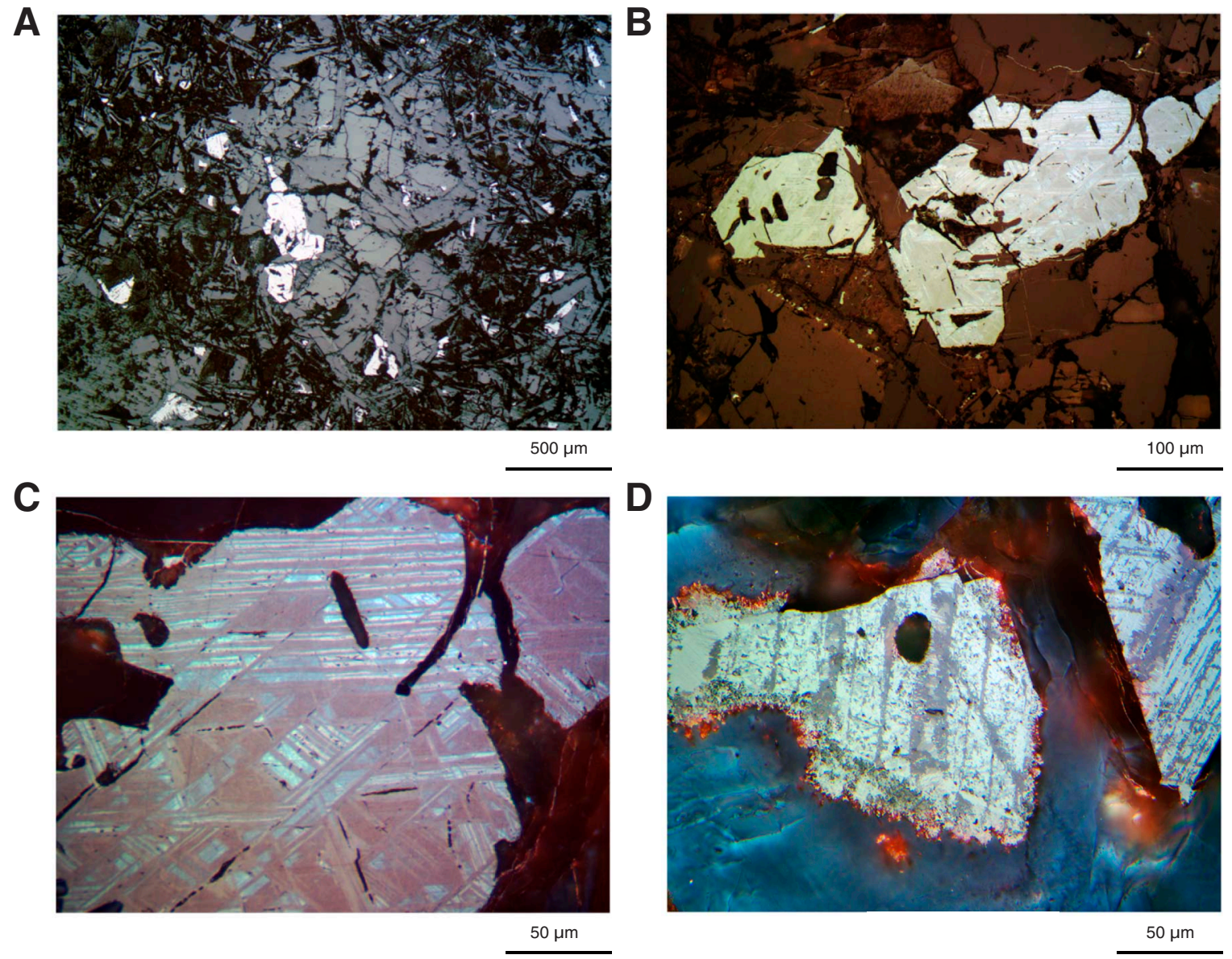
Figure F27. Photomicrographs of variation of exsolution and dissolution of groundmass titanomagnetite with depth, Hole U1349A. A. Skeletal titanomagnetite with fine ilmenite exsolution lamellae (right) next to spinel in olivine that has reticulate alteration on two sides but is unaltered within the rim of the olivine and has a titanomagnetite rim with exsolution lamellae; 168.05 mbsf (Thin Section 210; Sample 324-U1349A-7R-3, 111$113 \mathrm{~cm}$ ). B. Unusually broad ilmenite exsolution lamellae in an altered titanomagnetite; 166.25 mbsf (Thin Section 208; Sample 324-U1349A-7R-2, 78-81 cm). C. Spongy titanomagnetite with some exsolution features, but which is mainly irregularly dissolved around the crystal; 186.84 mbsf (Thin Section 222; Sample 324U1349A-13R-3, 97-99 cm). D. Well-formed skeletal titanomagnetite with a gridwork of exsolution lamellae in three different shades of gray; 205.05 mbsf (Thin Section 234; Sample 324-U1349A-12R-2, 111-113 cm). E. Titanomagnetite that has been almost completely eaten away, presumably leaving mainly a gridwork of ilmenite exsolution lamellae as the skeletal backbones of the crystals; 215.65 mbsf (Thin Section 241; Sample 324-U1349A-13R-3, 69-72 cm). Oil immersion and reflected light.
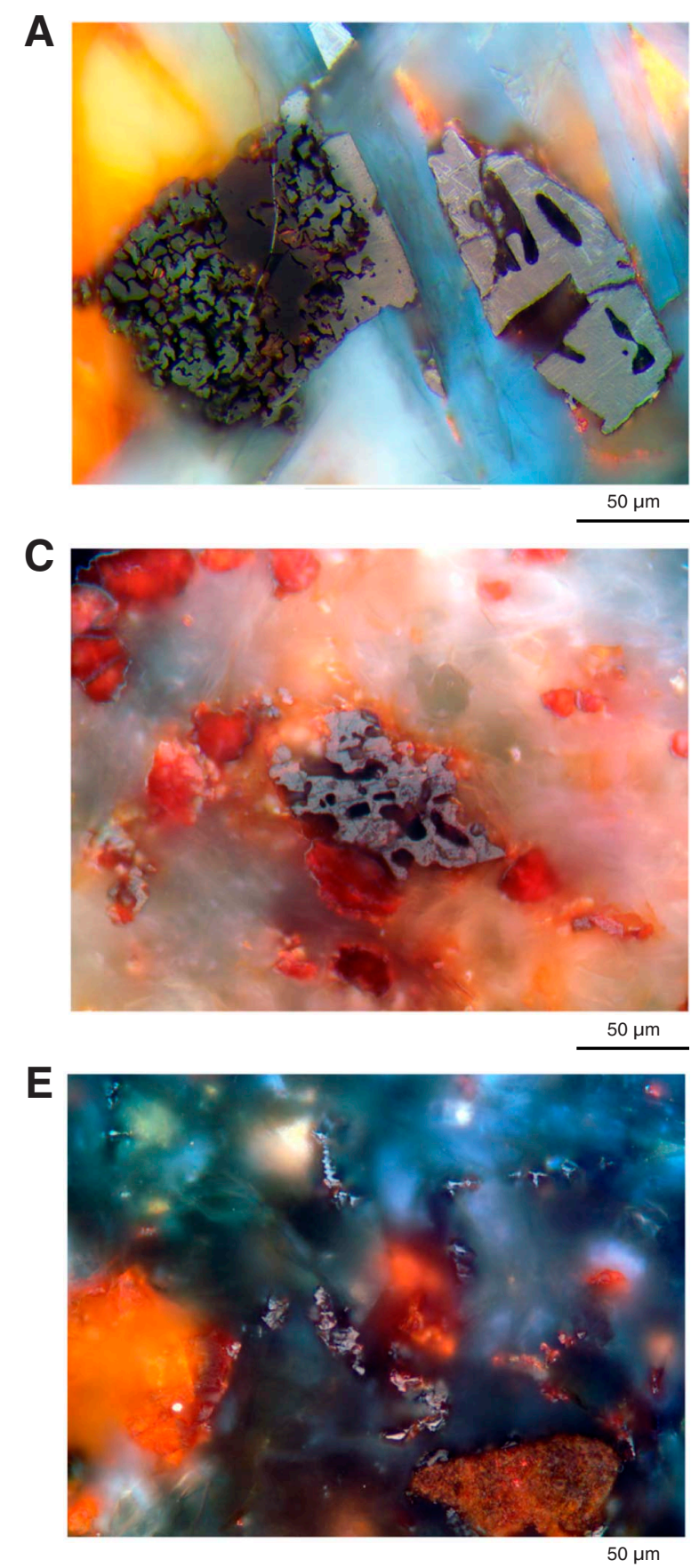

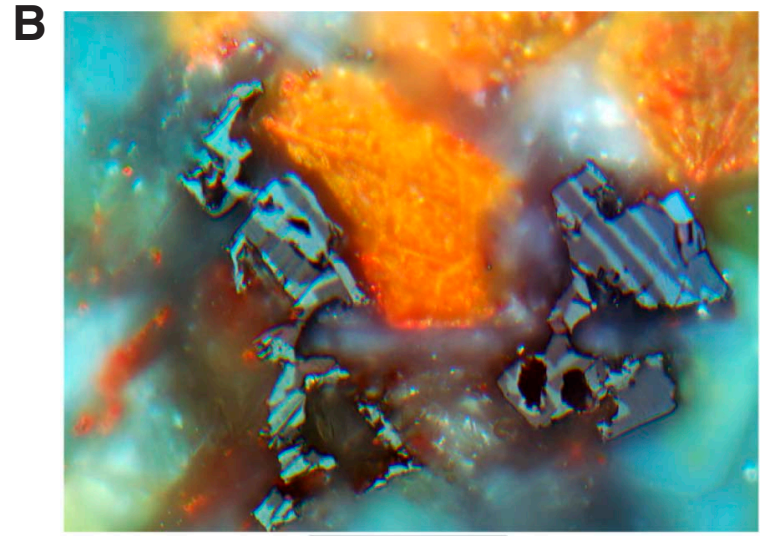

$50 \mu \mathrm{m}$

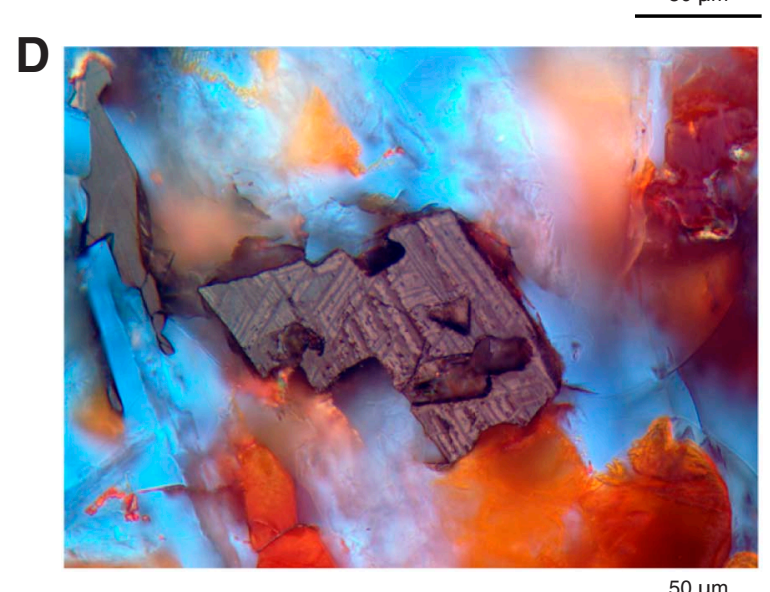

$50 \mu \mathrm{m}$ 
Figure F28. Photomicrographs of hematite in basalt in Unit IV, Hole U1349A (Thin Section 222; Sample 324U1349A-10R-3, 97-99 cm). A, B. Altered olivine enclosing two Cr spinel crystals, light gray in B. The numerous specks in the majority of the photomicrograph are variably crystalline iron oxyhydroxides and goethite(?)-hematite. In B, hematite lines small cracks crossing the altered olivine and outlines rims of some of the groundmass oxyhydroxides. C. Same as B at higher magnification. D. Hematite partly replacing altered clinopyroxene. E. High-magnification view of groundmass oxyhydroxides with hematite rims. Much of the view did not polish and so is outside of the restricted focal range of the objective and is therefore blurry. Two skeletal titanomagnetite crystals are gray with fine exsolution lamellae; the lower one is centered on a crystal that is almost completely transformed to hematite-oxyhydroxide (red internal reflections surrounding the gray). A is under transmitted with partially reflected light; B and C are under reflected light; D is under transmitted light; $\mathrm{E}$ is under oil-immersion reflected light.
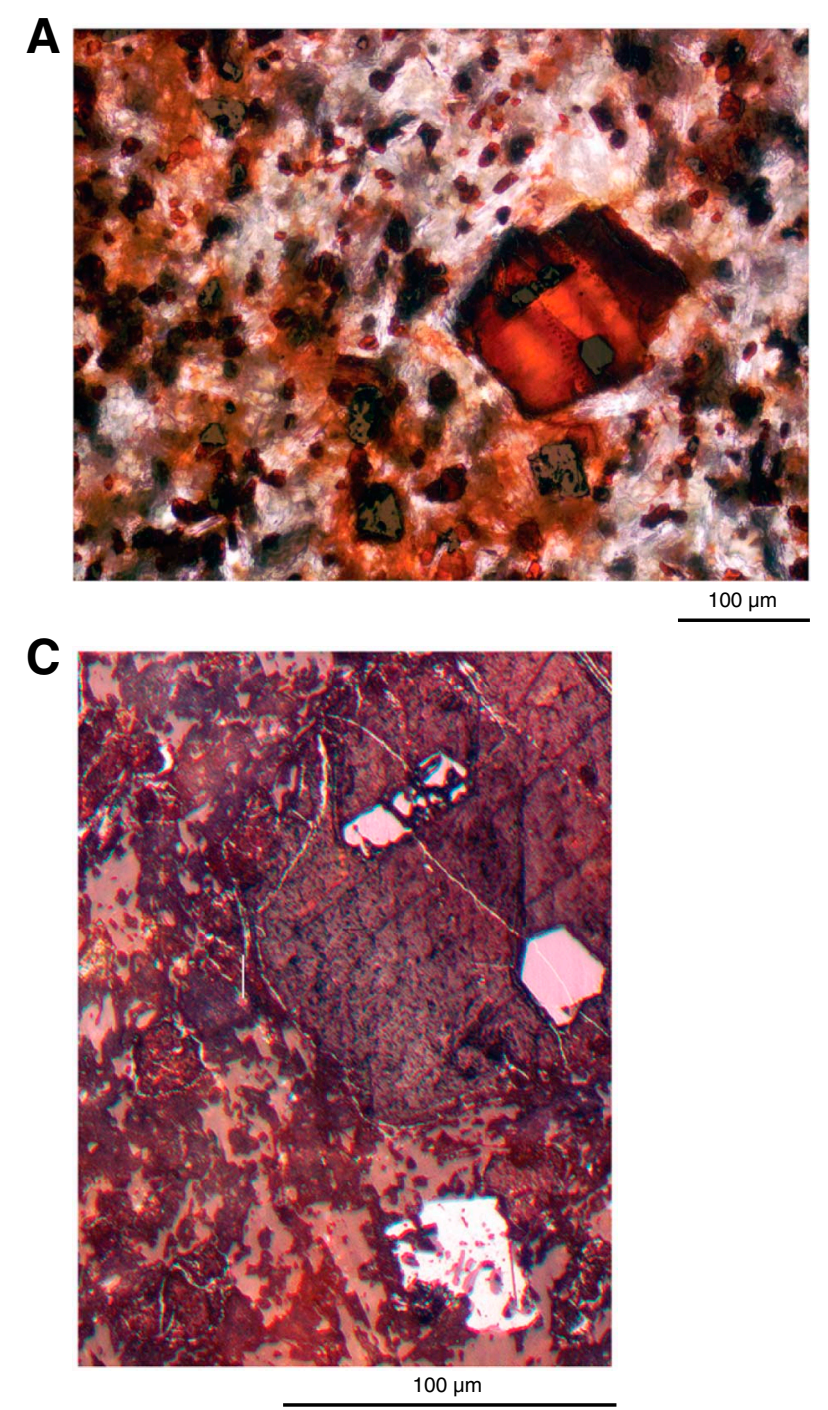

$100 \mu \mathrm{m}$
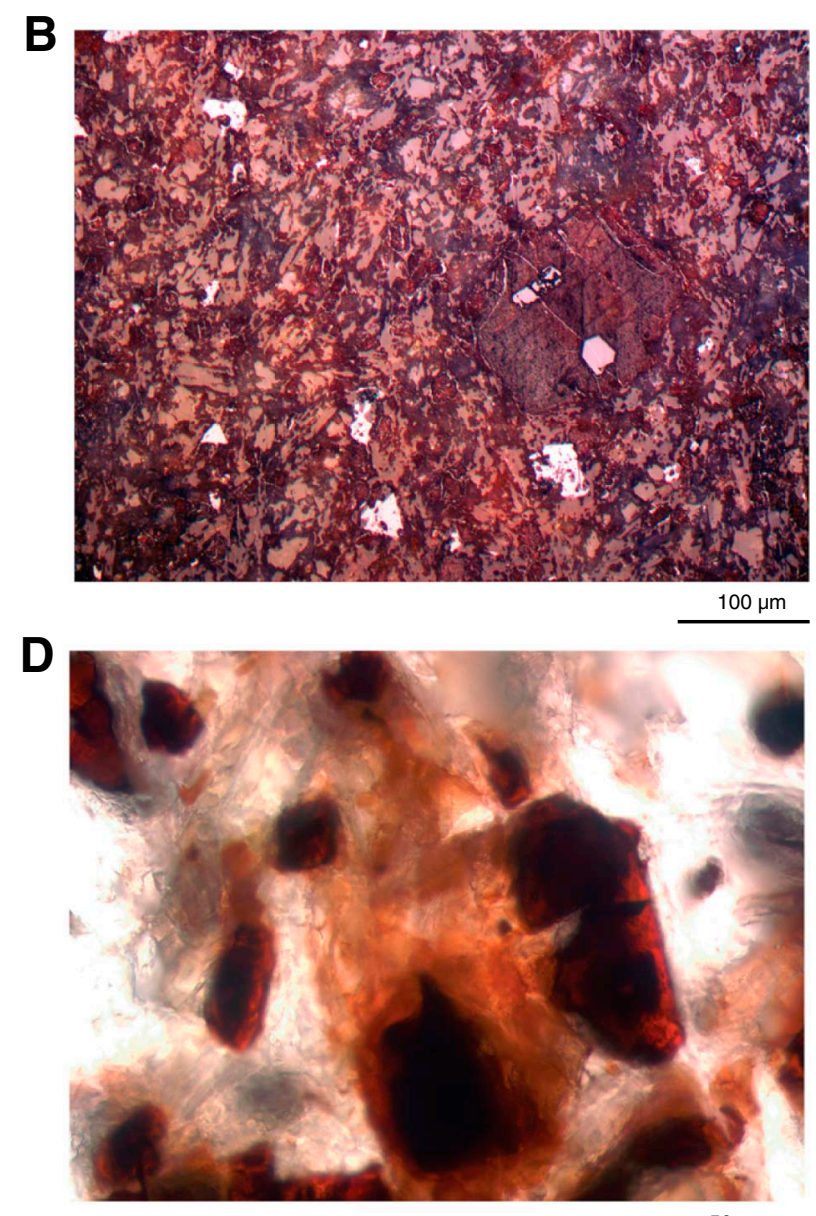

E

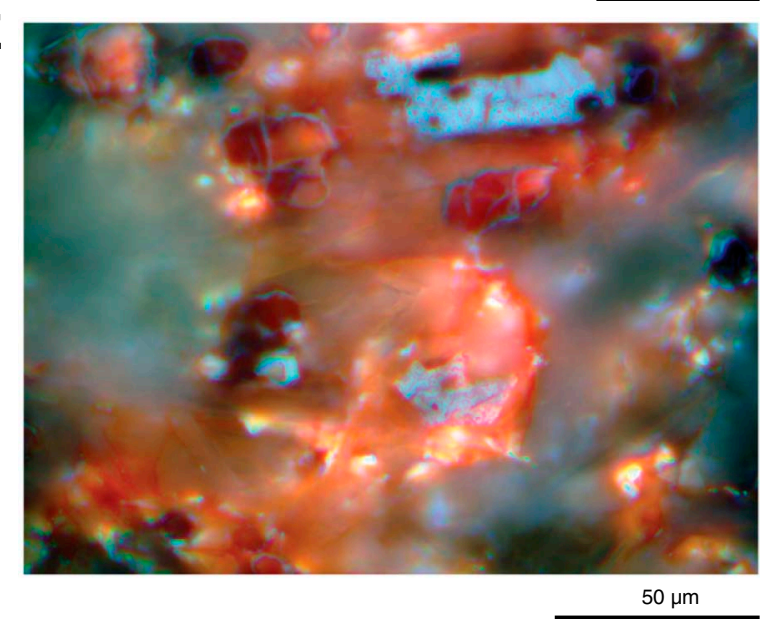


Figure F29. Thin section images using different techniques (Thin Section 211; Sample 324-U1349A-7R-4, 32$35 \mathrm{~cm}$ ). A. White background showing rock contrasted with filled vesicles. Altered olivine with spinel occurs at the upper left and lower center middle. B. Scanning light passed up through the section to a dark background. This reveals outlines of the infilling calcite, subduing the image of the rock itself except to show how strongly stained it is with iron oxyhydroxides.

A

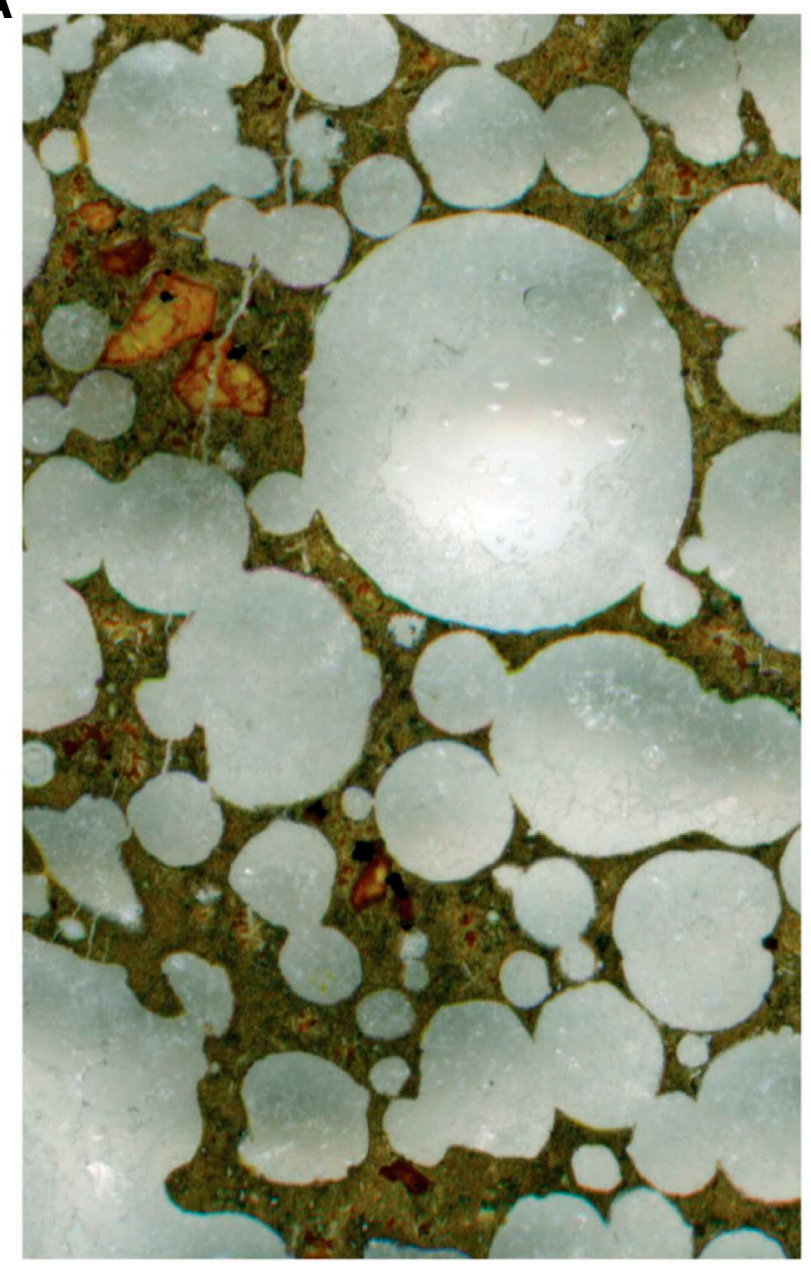

B

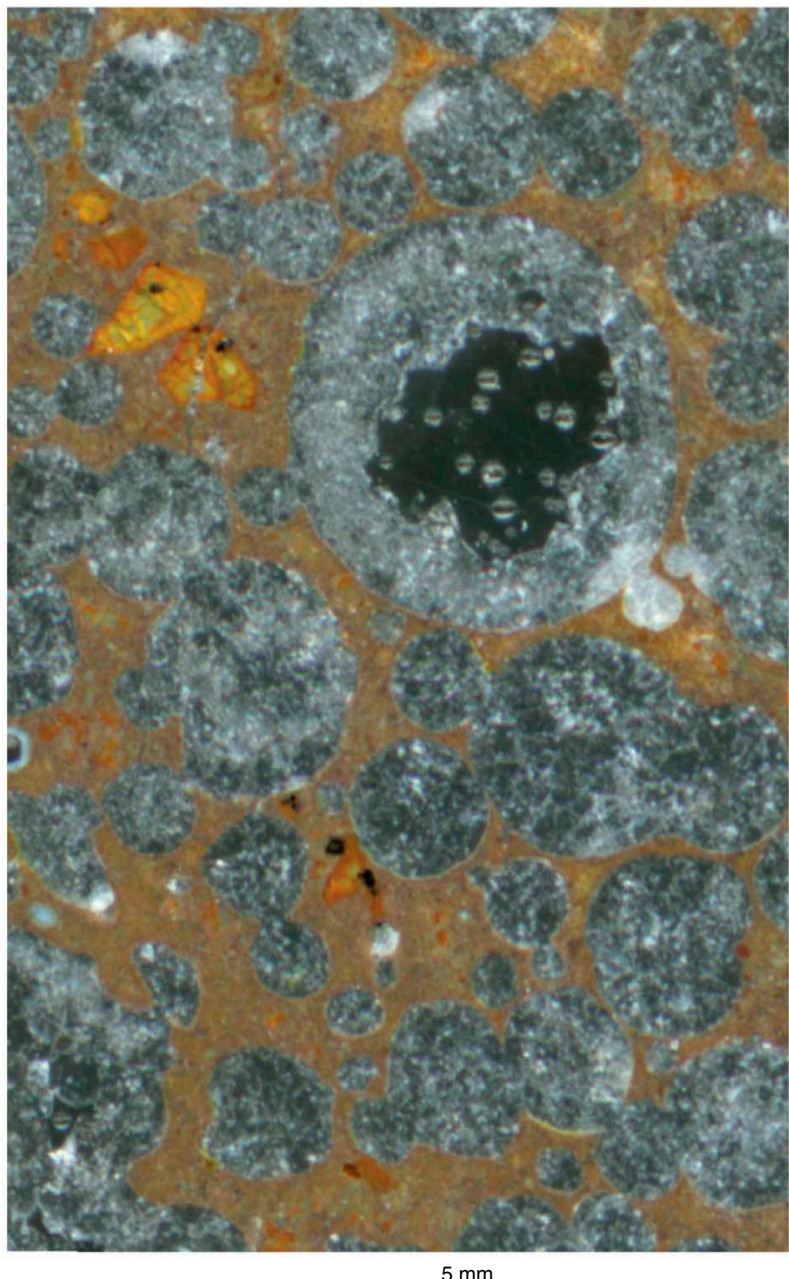


Figure F30. Thin section image of a hybrid rock, Hole U1349A (Thin Section 222; Sample 324-U1349A-10R-3, 97-99 cm). Ophimottled rock with variable amounts of olivine is at the upper right and lower left. A diagonal band $\sim 0.5 \mathrm{~cm}$ wide crosses the section. White veins are calcite. The band of fine-grained basalt has scattered altered olivine but no plagioclase-clinopyroxene intergrowths. Since all portions of the rock had virtually the same cooling rate, yet the crystals within the diagonal band are finer grained, it had the higher liquidus temperature, thus crystals within it were more greatly undercooled as they grew and are smaller.

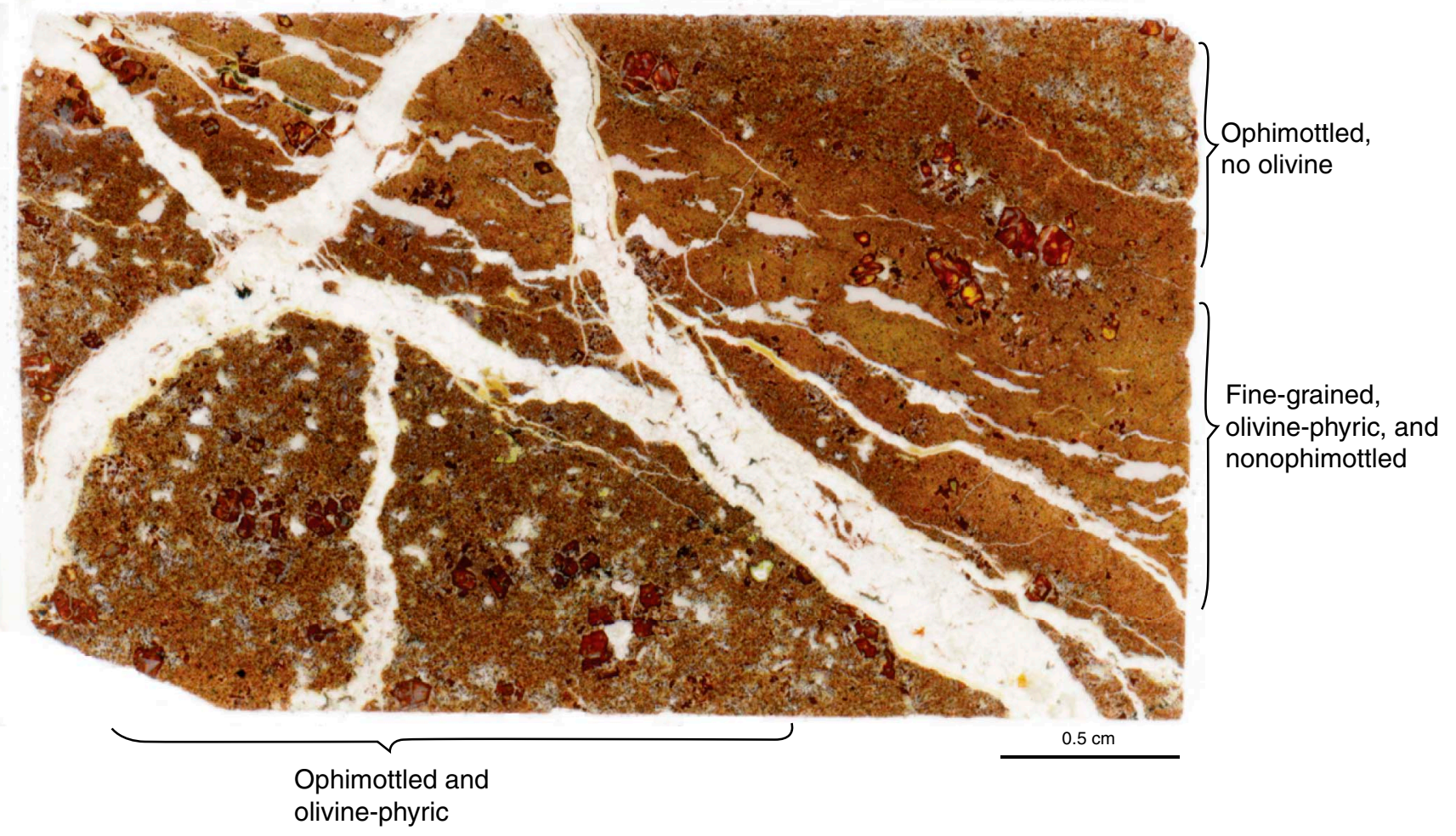


Figure F31. A. Partial thin section image, Hole U1349A (Thin Section 230; Sample 324-U1349A-11R-5, 11-14 $\mathbf{c m})$. The two sides of the scan, orange and gray with white vesicles, are two different basalt compositions that cooled side by side and partially blended with each other in the variegated center of the scan. The material on the left is far more vesicular than that on the right, and in the central band, the orange-colored basalt filled vesicles of the gray. The gray material has $\sim 75 \%$ vesicles, now filled with calcite. Arrow = orientation in core. B-D. Photomicrographs of the orange material in A at successively greater distances from blending zone, showing an increase of crystallinity of both plagioclase (white) and dendritic clinopyroxene (feathery brown, now altered). Photomicrograph location of B is indicated by red box in A. Transmitted light. E. Higher magnification image of one of the olivine crystals at lower center in A (location is indicated by red box). Crystal contains a trellised grid of hematite crystals, which are inferred to replace originally exsolved low-Ti magnetite during high-temperature alteration of the olivine.

A

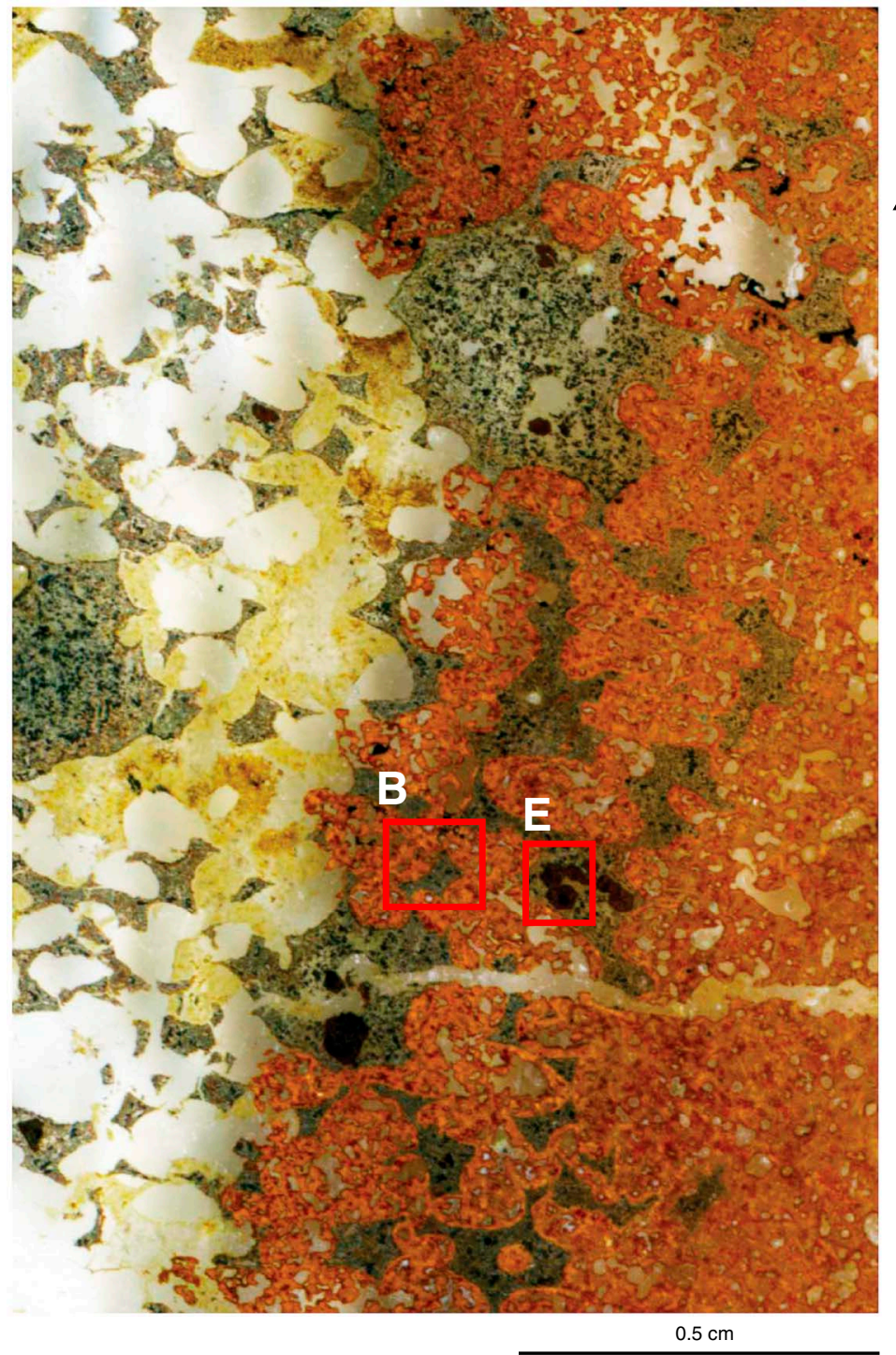

B

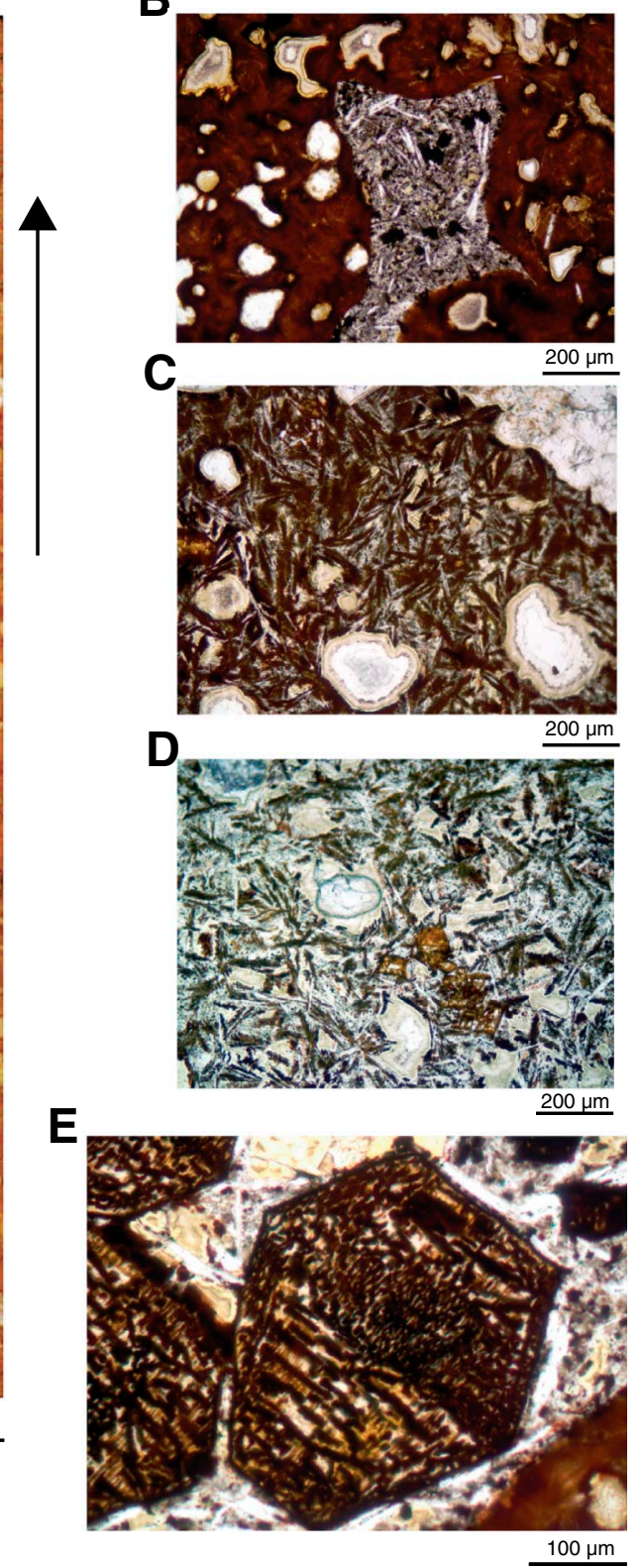


Figure F32. Photomicrographs of textural variation from rim to interior of an altered hyaloclastite breccia fragment in Unit V, Hole U1349A (Thin Section 258; Sample 324-U1349A-16R-2, 7-14 cm). A-D. Increasing crystallinity from the altered glass rim (with chloritized edge) in A to zones of acicular plagioclase microlites in $\mathrm{B}$ and $\mathrm{C}$, and finally incipient development of plagioclase-clinopyroxene network structure set in a darker and finer grained matrix in D. Olivine phenocrysts present in A-C are altered to brown clays with green chloritic rims but retain small crystals of Cr spinel. E. Remnants of three hopper olivine crystals set in a matrix with more and less crystalline portions, as in D. F. One of a number of unusual button-shaped objects, consisting of bundles or sheafs of a fine needle-like mineral with intermediate birefringence. These may be incipient clinopyroxene rosettes that are now altered to clay minerals. Transmitted light.
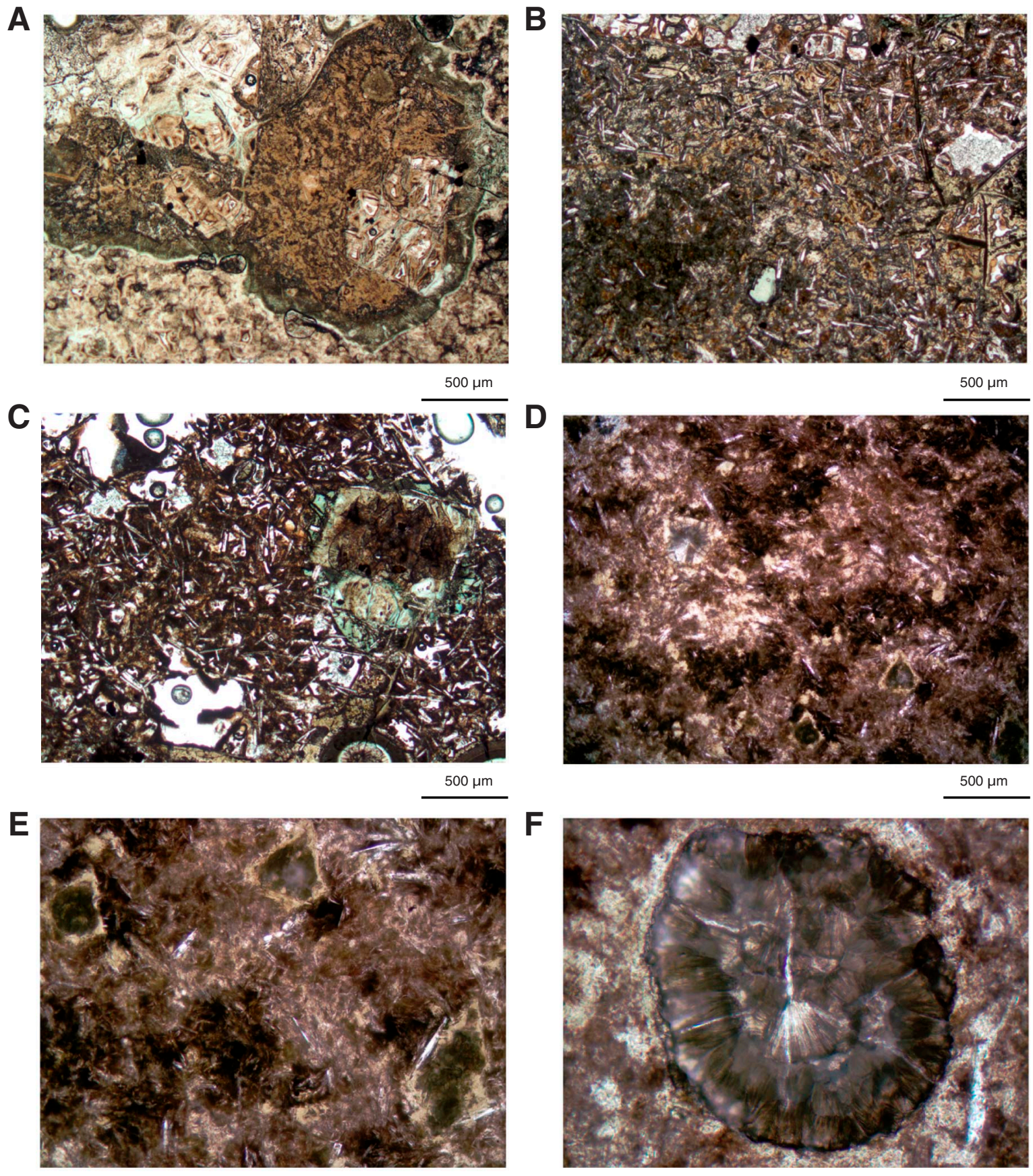

$500 \mu \mathrm{m}$

$500 \mu \mathrm{m}$ 
Figure F33. Photomicrograph of textural variation from rim to interior of a second altered hyaloclastite breccia fragment in Unit V, Hole U1349A. Note the presence of brown Cr spinel (Thin Section 262; Sample 324U1349A-16R-6, 71-73 cm). A, B. Pale brown altered glass formerly altered to palagonite, as evidenced by the remnant fibrous clay rims. The rock has only incipient plagioclase microlites in altered glass at the rim, but they are linked in a network within $\sim 1 \mathrm{~cm}$ of the edge in B. C. Small bundles of sheaf spherulites around the microlites. D. Skeletal and dendritic longer crystals and individual acicular plagioclase, with well-developed radiating sheafs. E. Zones of different spherulitic crystallinity in the same part of the thin section. Transmitted light.

A
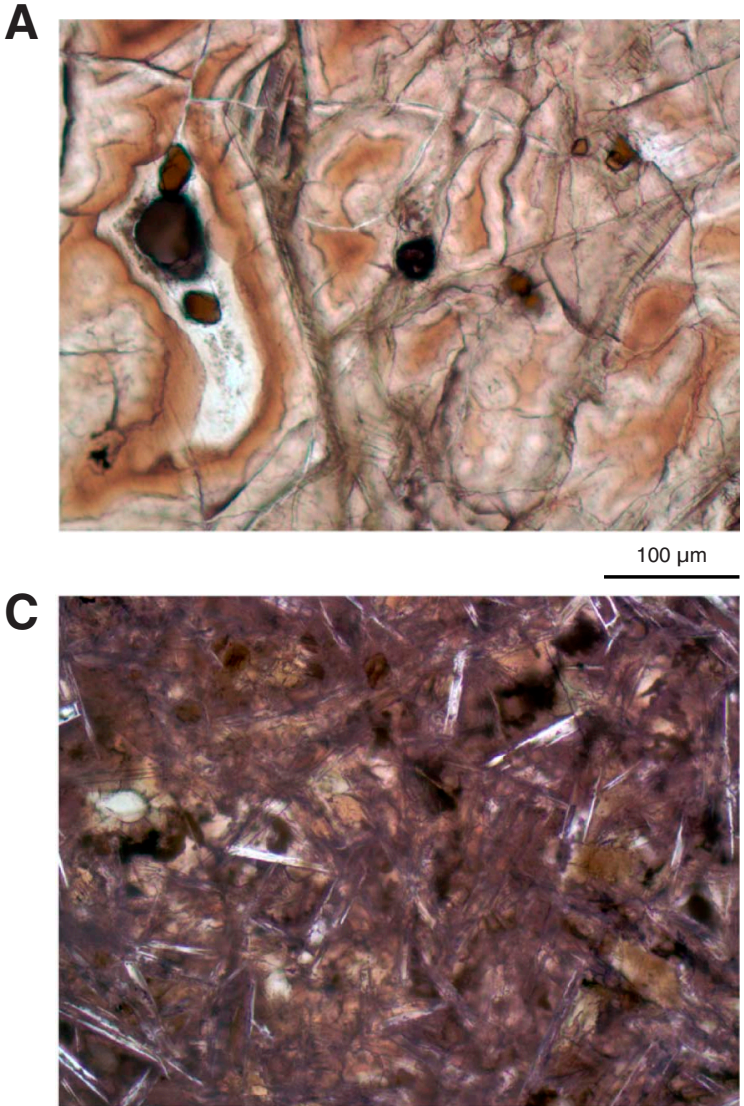

$100 \mu \mathrm{m}$

E

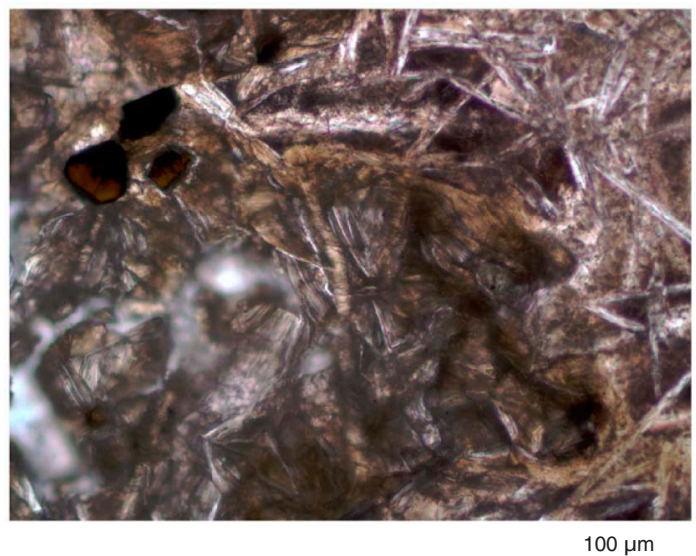

B
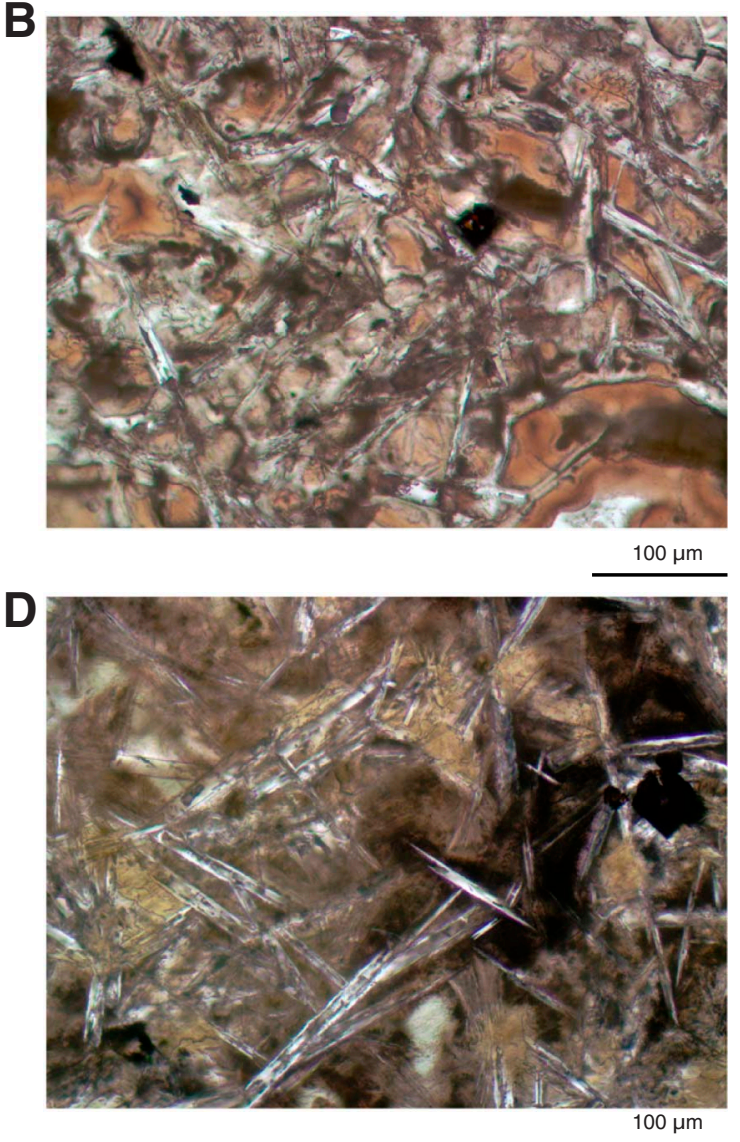
Figure F34. Photomicrographs of altered olivine phenocrysts in Unit V, Hole U1349A. A. Low-magnification perspective of the clustering and abundance of olivine ( $5 \%$ of the rock). Olivine is replaced by light-colored clay minerals or chlorite. Iron oxyhydroxides are still concentrated near olivine rims and along former fractures (Thin Section 261; Sample 324-U1349A-16R-6, 56-61 cm). B. Altered olivine phenocryst, 2 mm in diameter, replaced by clear clays or chlorite and iron oxyhydroxide (Thin Section 248; Sample 324-U1349A-14R-5, 25$31 \mathrm{~cm})$. C-E. Three olivine phenocrysts $0.5-1.5 \mathrm{~mm}$ in length replaced by a clear fibrous mineral with low firstorder birefringence (lizardite?). Residues of cracks are now lined with more highly birefringent clay and residual iron oxyhydroxide or hematite is present in C and D. Cr spinel is present in all three olivine crystals and is prominent in D. The adjacent bright mineral in D is altered plagioclase (Thin Section 261; Sample 324U1349A-16R-6, 10-12 cm). A and B are under transmitted light; C-E are under cross-polarized light.

A
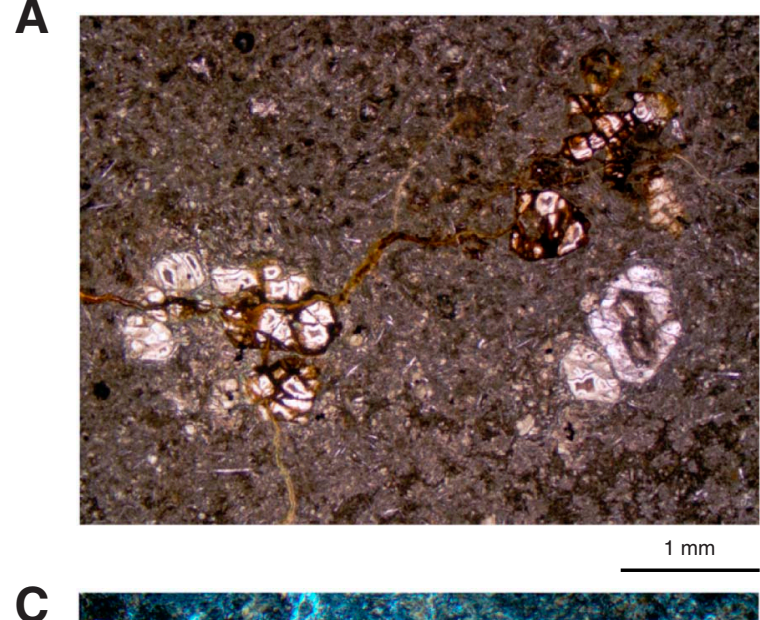

C

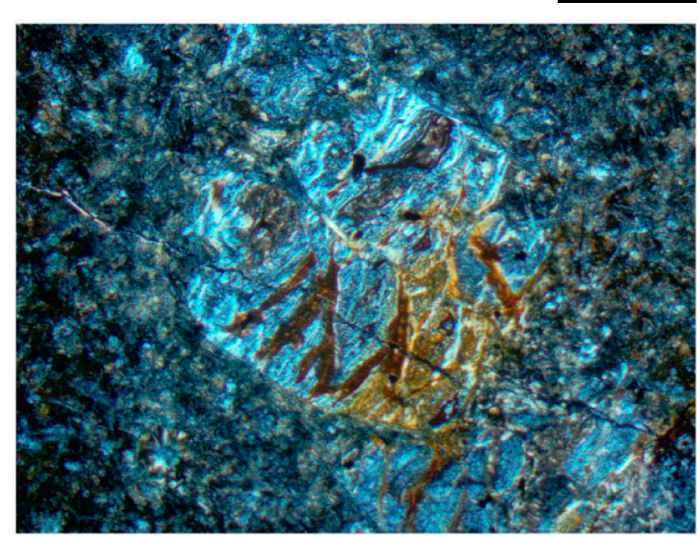

$500 \mu \mathrm{m}$

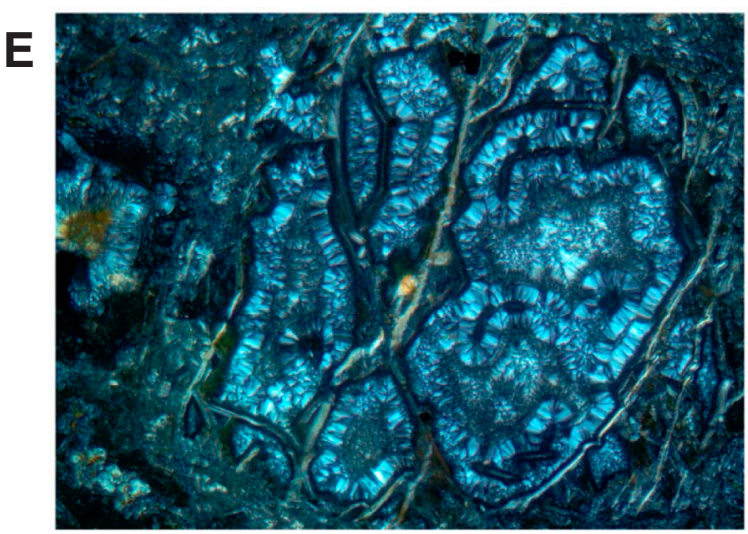

B
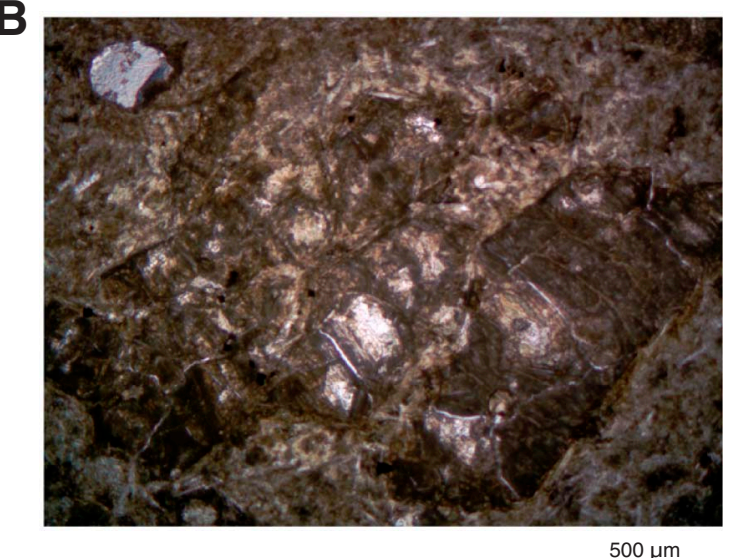

D

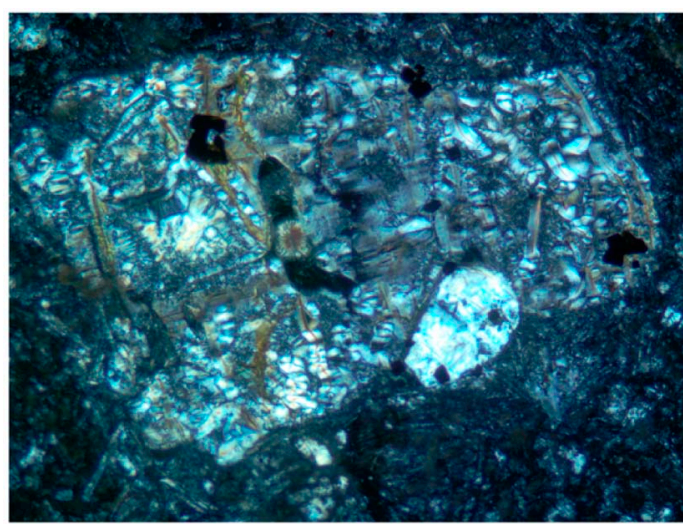

$500 \mu \mathrm{m}$

$500 \mu \mathrm{m}$ 
Figure F35. Photomicrographs of spinel in Unit V, Hole U1349A. A-C. In A, euhedral spinel crystals with incipient reticulate alteration embaying a possible original skeletal interior is present. In $\mathrm{B}$, one of the several crystals has a bleached and fretted margin resulting from alteration. In C, the crystals are greenish brown and one of them has an altered reticulate rim (Thin Section 250; Sample 324-U1349A-14R-6, 64-67 cm). D. Cluster of brown spinel crystals in a groundmass of altered acicular and spherulitic plagioclase and subhedral altered clinopyroxene (yellow) (Thin Section 258; Sample 324-U1349A-16R-2, 7-14 cm). E. Skeletal brown spinel (right center) above a possible altered olivine replaced by iron oxyhydroxides. A possible clinopyroxene rosette is to the left (Thin Section 261; Sample 324-U1349A-16R-6, 56-61 cm). A-C are under combined transmitted and oil-immersion reflected light; D and $\mathrm{E}$ are under transmitted light.

A

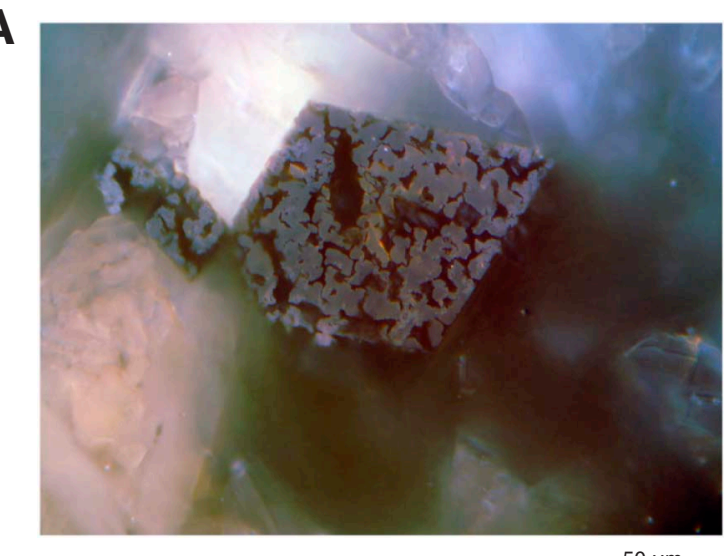

C

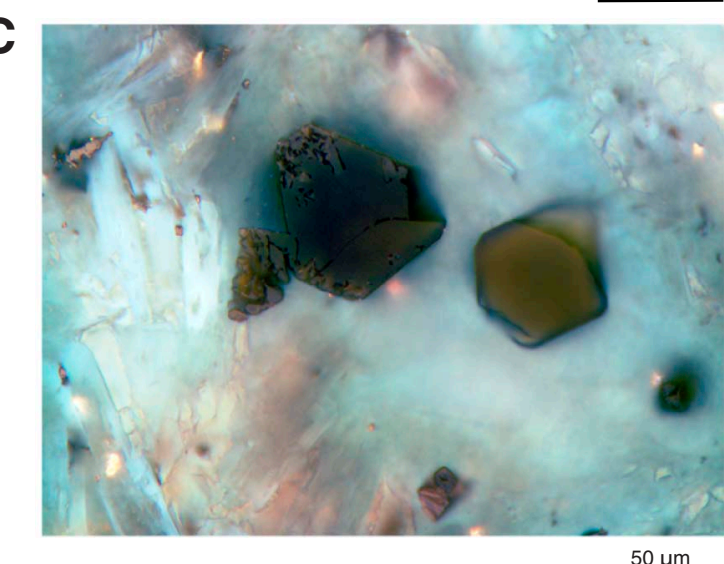

E

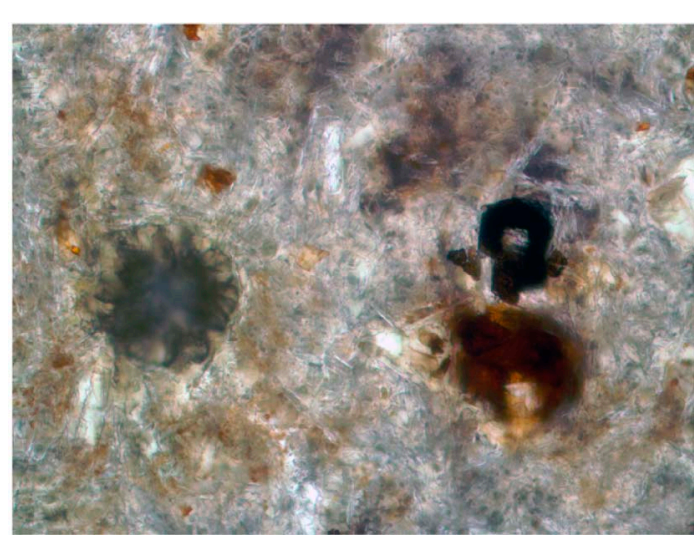

$100 \mu \mathrm{m}$
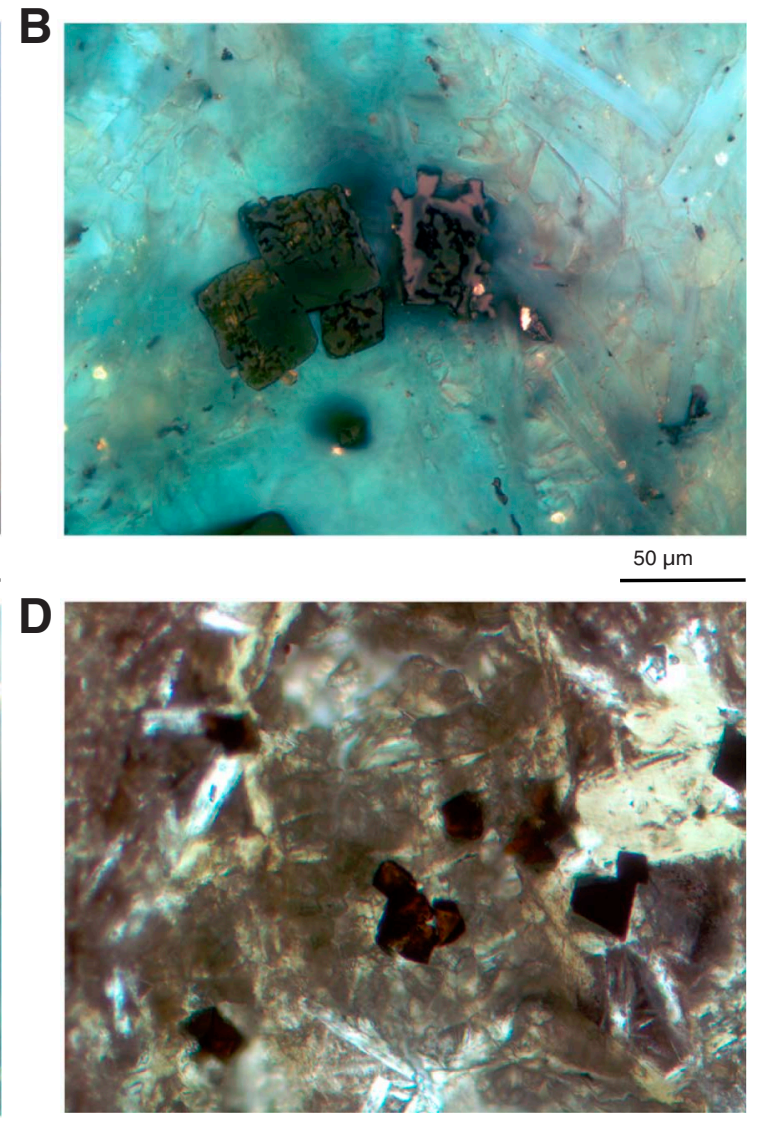

$100 \mu \mathrm{m}$ 
Figure F36. Photomicrographs of Thin Section 257 (Sample 324-U1349A-15R-6, 42-44 cm) in Unit V, Hole U1349A. A. Unusually large Cr spinel crystal aggregate set in a sheaf-spherulitic matrix. The aggregate has a skeletal appearance, but this morphology is not borne out by closer inspection. B. Grain consisting of differently oriented crystals with miscellaneous shapes in cross section. Note the high percentage of reflective plagioclase (gray) and clinopyroxene (lighter gray) within the interior of the aggregate. The silicates are coarser grained than they are in the spherulitic matrix outside the aggregate (upper right). C. Enlarged view of a portion of the interior of the aggregate. The brown spinel is arranged in clusters that are not part of a larger skeletal structure. Many tiny crystals of unaltered $\mathrm{Cr}$ spinel with cubic or diamond-shaped morphologies make up each cluster, and these have diverse shapes. A and C are under transmitted light; B is under reflected light.
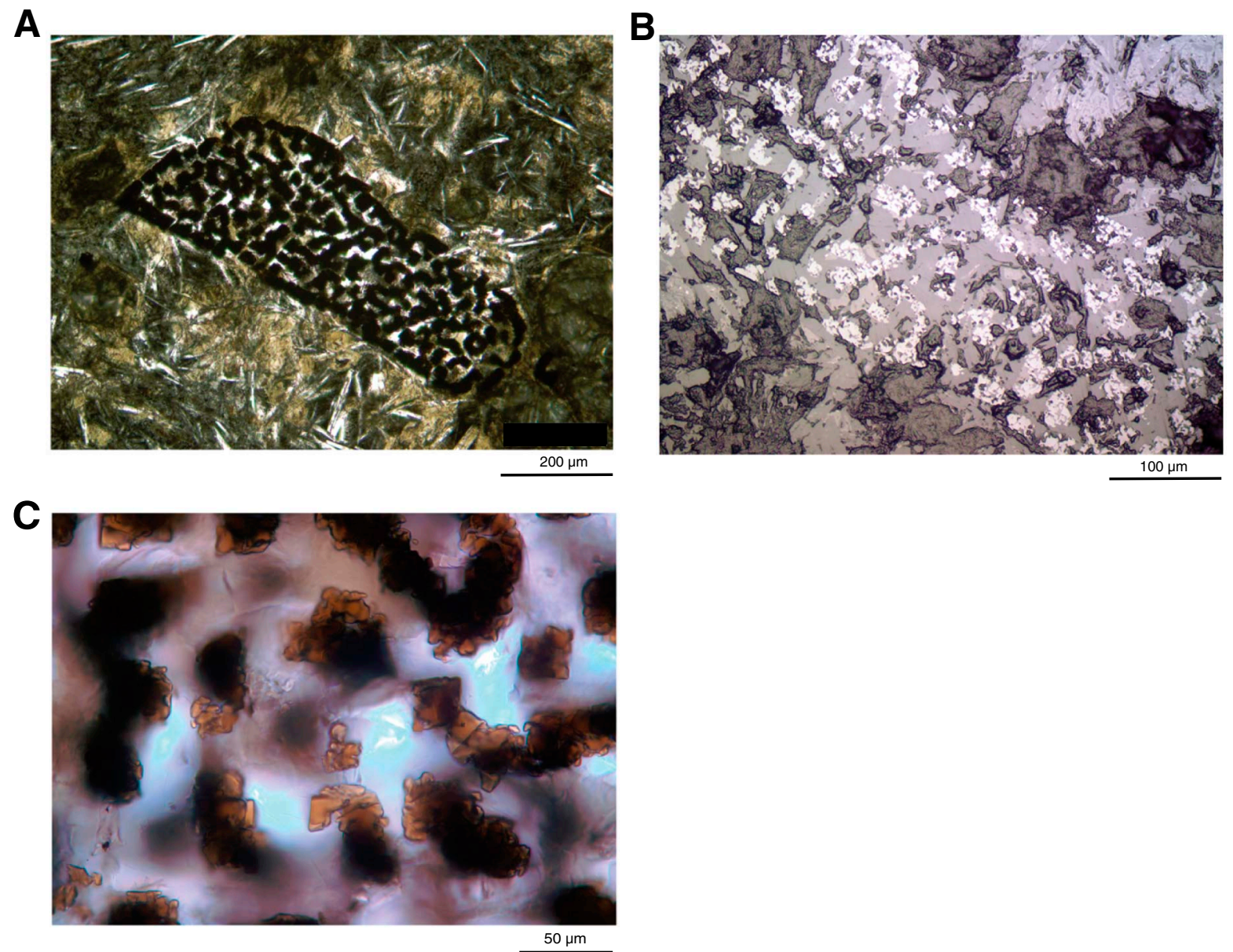
Figure F37. Downhole variations, Hole U1349A. Vein thickness, degree of alteration, and alteration color are based on visual core description. Olivine alteration mineralogy, clinopyroxene occurrences, and vein mineralogy are based on thin section descriptions.

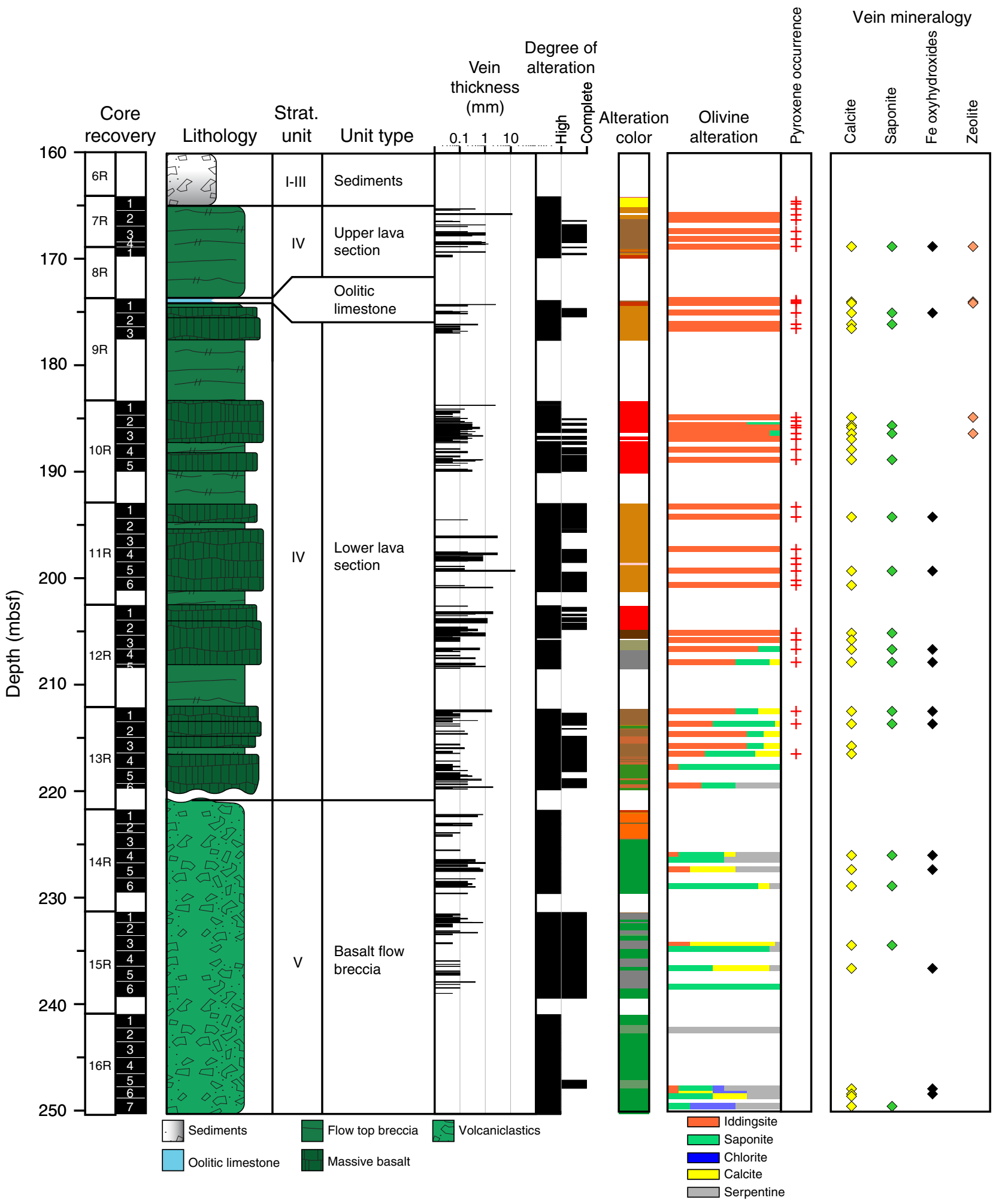


Figure F38. A, B. Photomicrographs of olivine phenocryst pseudomorphed by iddingsite, Hole U1349A (Thin Section 216; Sample 324-U1349A-9R-1, 127-132 cm). A is under plane-polarized light; B is under cross-polarized light.
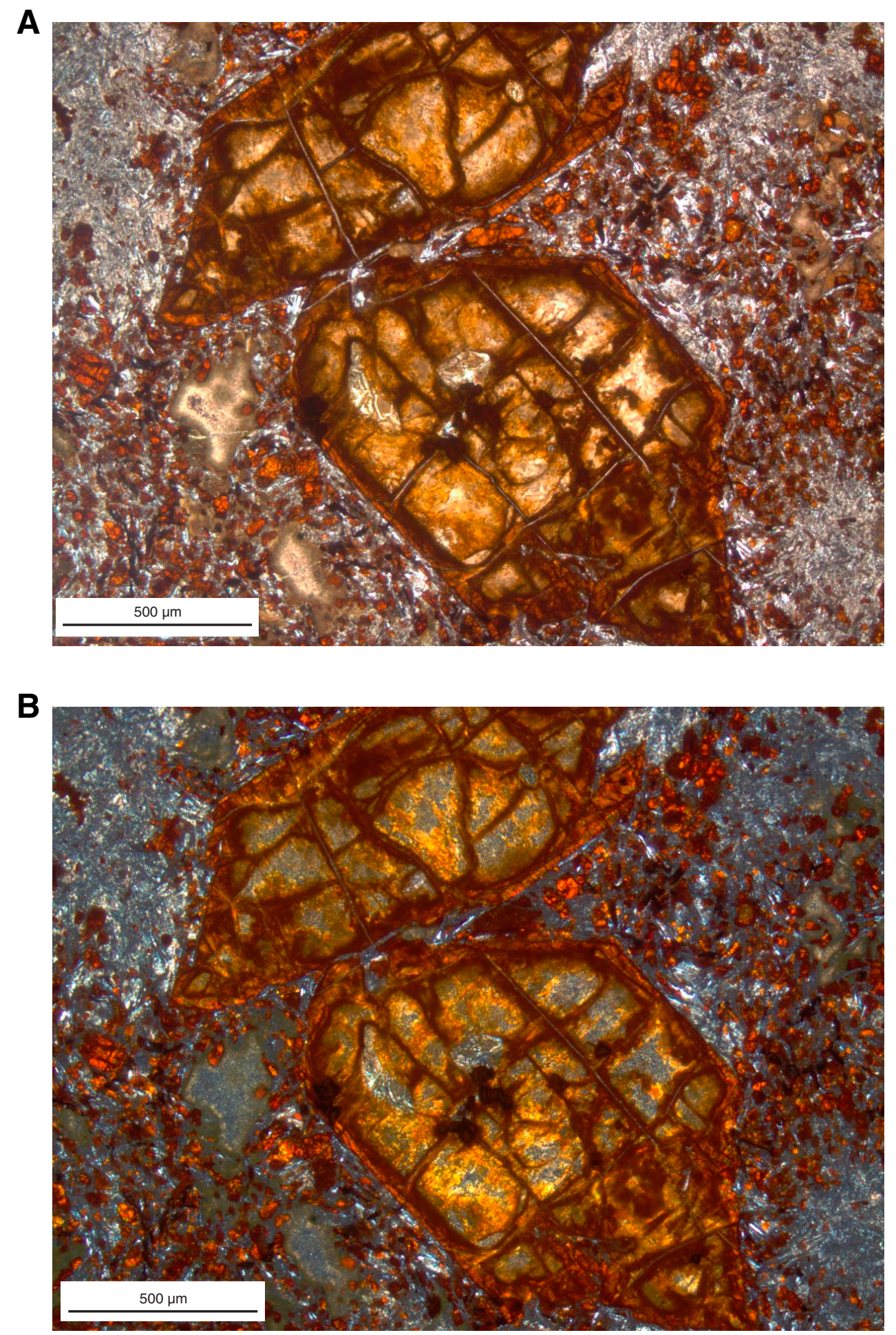
Figure F39. Photomicrograph of hematite in olivine phenocryst altered to iddingsite, Hole U1349A (Thin Sample 222; Sample 324-U1349A-10R-3, 97-99 cm). Reflected light with oil immersion.

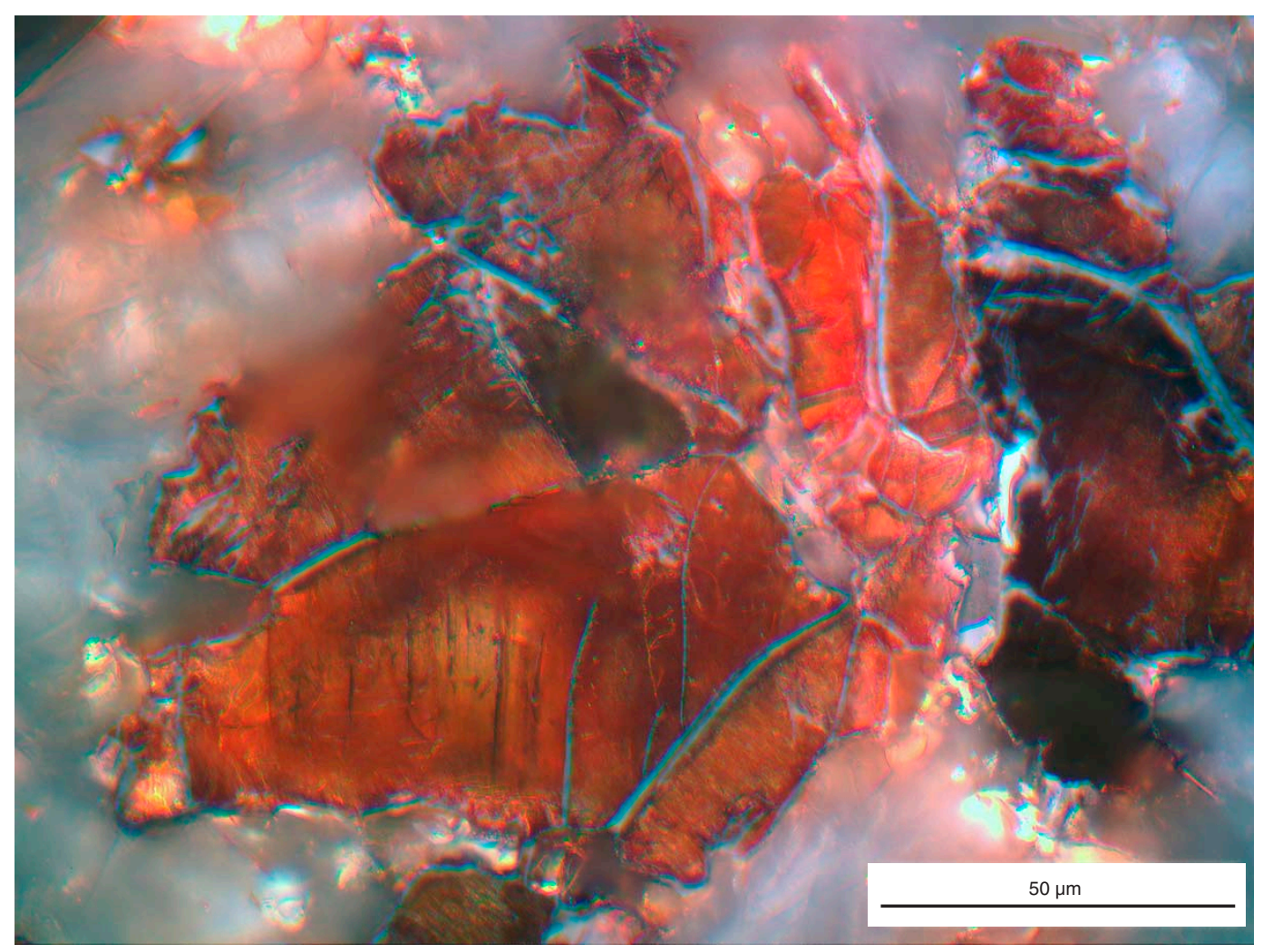


Figure F40. X-ray diffraction spectrum of bulk rock with peaks for montmorillonite, saponite (replacing the olivine phenocryst), calcite (present as vein in the rock), anorthite, and sanidine (likely as an alteration product of plagioclase microliths), Hole U1349A (Sample 324-U1349A-7R-3, 111-113 cm). Two end-member saponites $\left(4 \mathrm{MgO}_{2}\left[\mathrm{Al}_{2} \mathrm{O}_{3}\right] 11\left[\mathrm{SiO}_{2}\right] \cdot 15.5\left[\mathrm{H}_{2} \mathrm{O}\right]\right)$ are shown with slightly different crystal structures. From the Bruker Diffrac plus EVA XRD program database (003: saponite 00-003-0179; 002: saponite 00-002-0218).

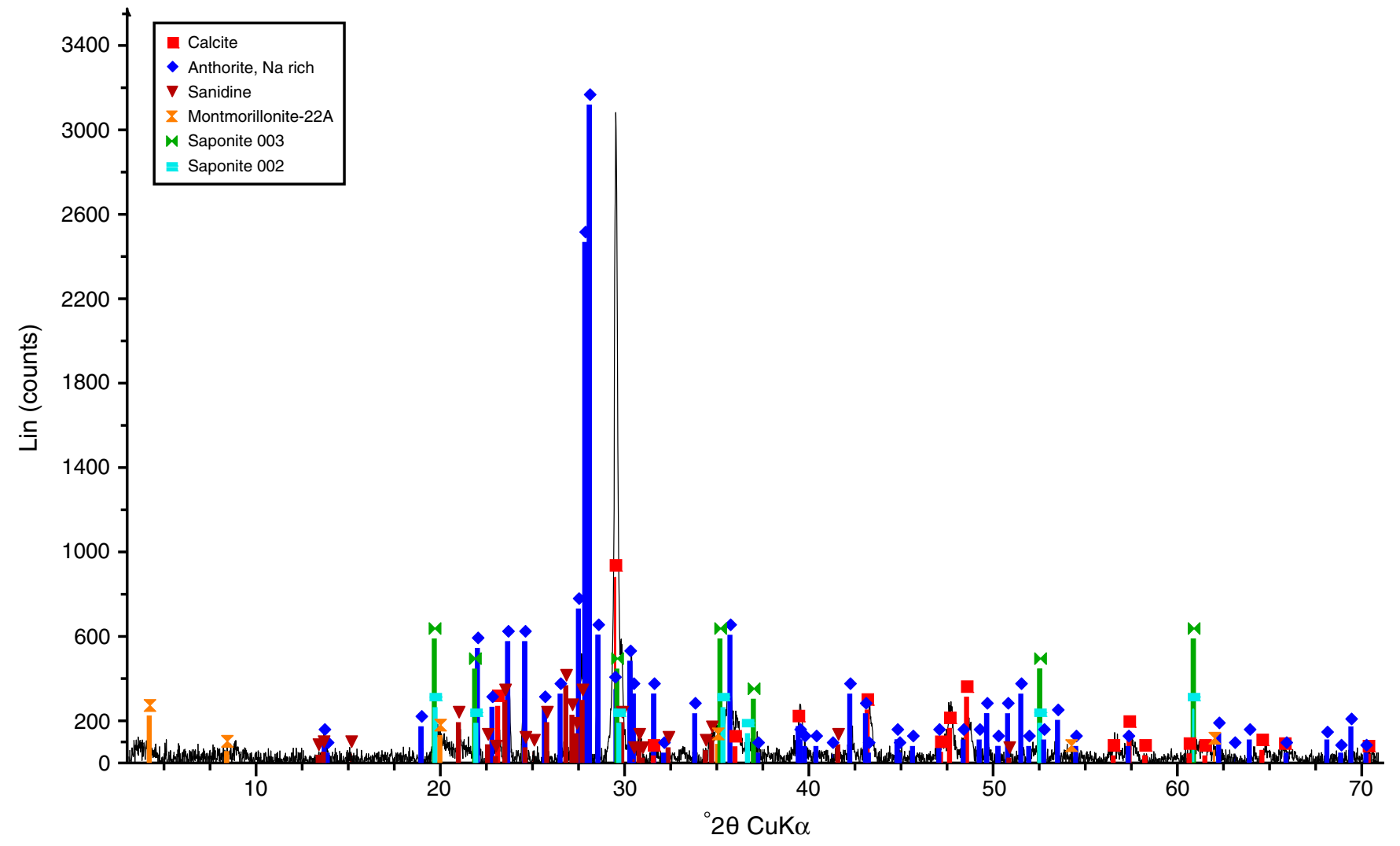


Figure F41. Photomicrograph of the exsolution of magnetite and ilmenite after alteration of primary titanomagnetite, Hole U1349A (Thin Section 219; Sample 324-U1349A-10R-2, 1-2 cm). Reflected light.

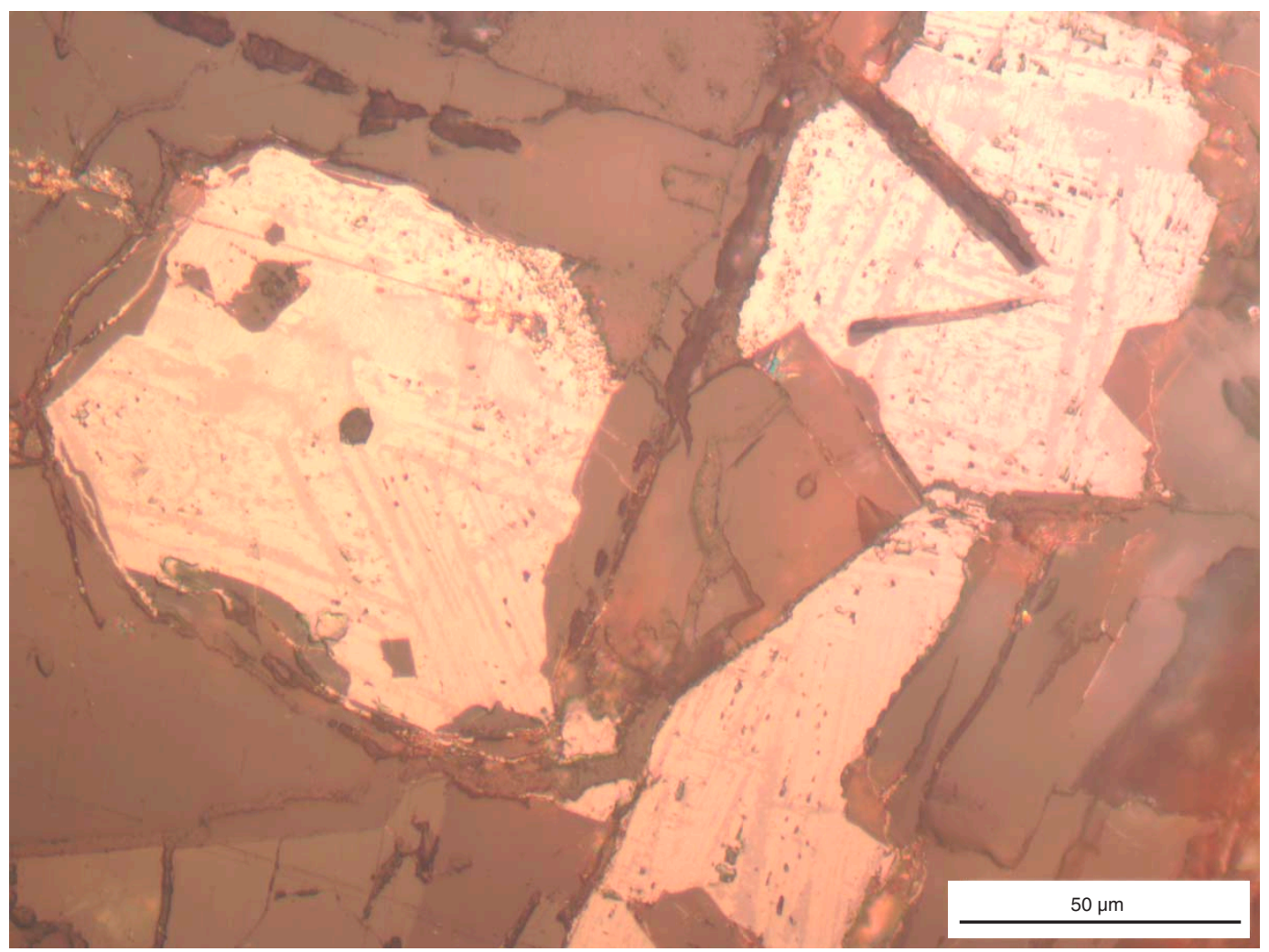


Figure F42. Photomicrograph of relatively fresh clinopyroxene crystals, Hole U1349A (Thin Section 216; Sample 324-U1349A-9R-1, 127-132 cm). Cross-polarized light.

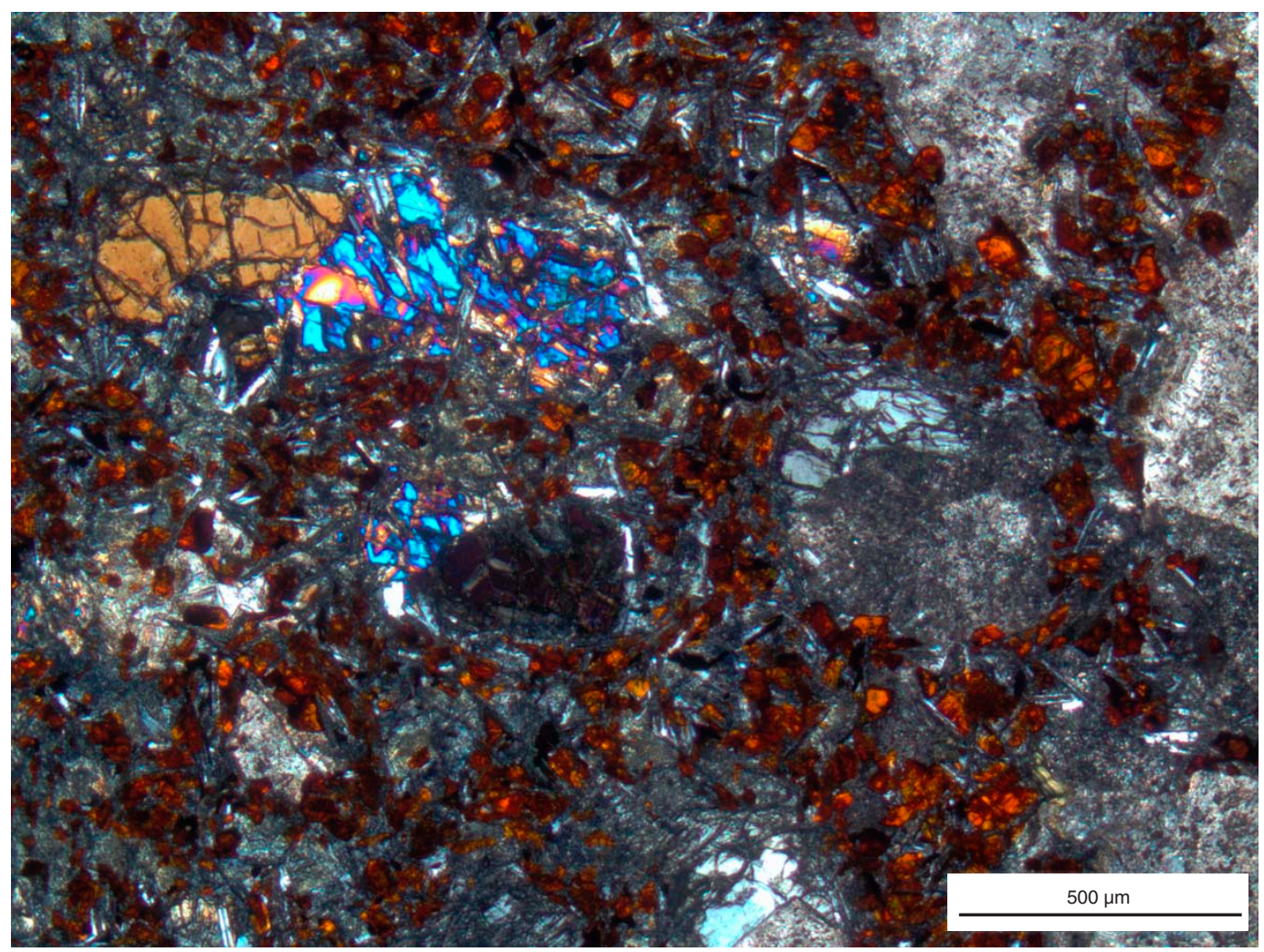


Figure F43. A. Lithostratigraphic schematic representation, Hole U1349A. Light brown shading = intervals interpreted to be subaerially weathered flow tops. B. X-ray diffraction spectrum of bulk rock indicating that the rock is predominantly composed of hematite $\left(\mathrm{Fe}_{2} \mathrm{O}_{3}\right)$, goethite $(\mathrm{FeO}[\mathrm{OH}])$, sanidine, montmorillonite, and halloysite $\left(\mathrm{Al}_{2} \mathrm{Si}_{2} \mathrm{O}_{5}[\mathrm{OH}] 4 \cdot 2 \mathrm{H}_{2} \mathrm{O}\right)$ (Sample 324-U1349A-10R-1, 10-13 cm).

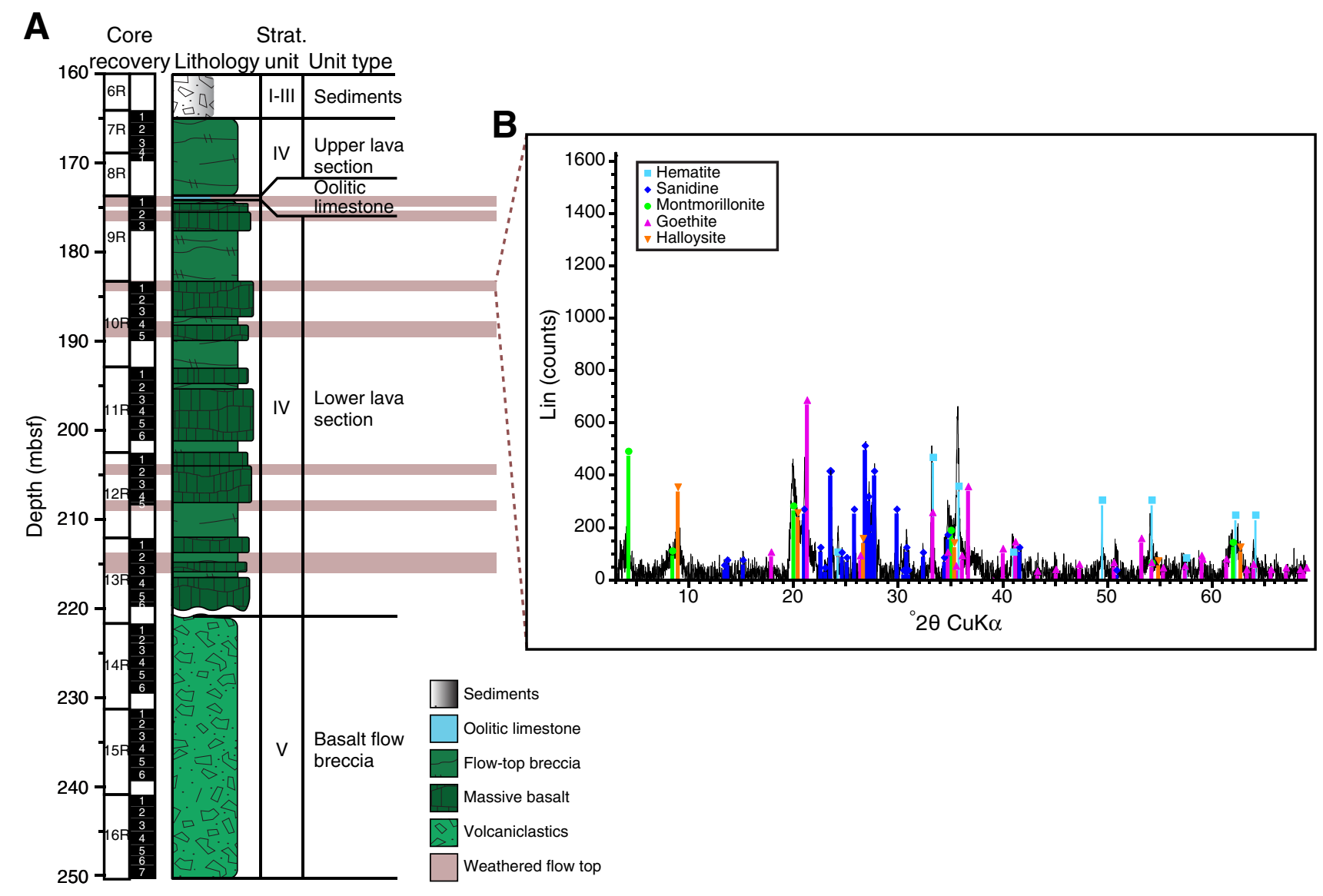


Figure F44. A, B. Photomicrographs of olivine phenocryst altered to saponite and calcite, Hole U1349A (Thin Section 234; Sample 324-U1349A-12R-2, 111-113 cm). A is under plane-polarized light; B is under cross-polarized light.
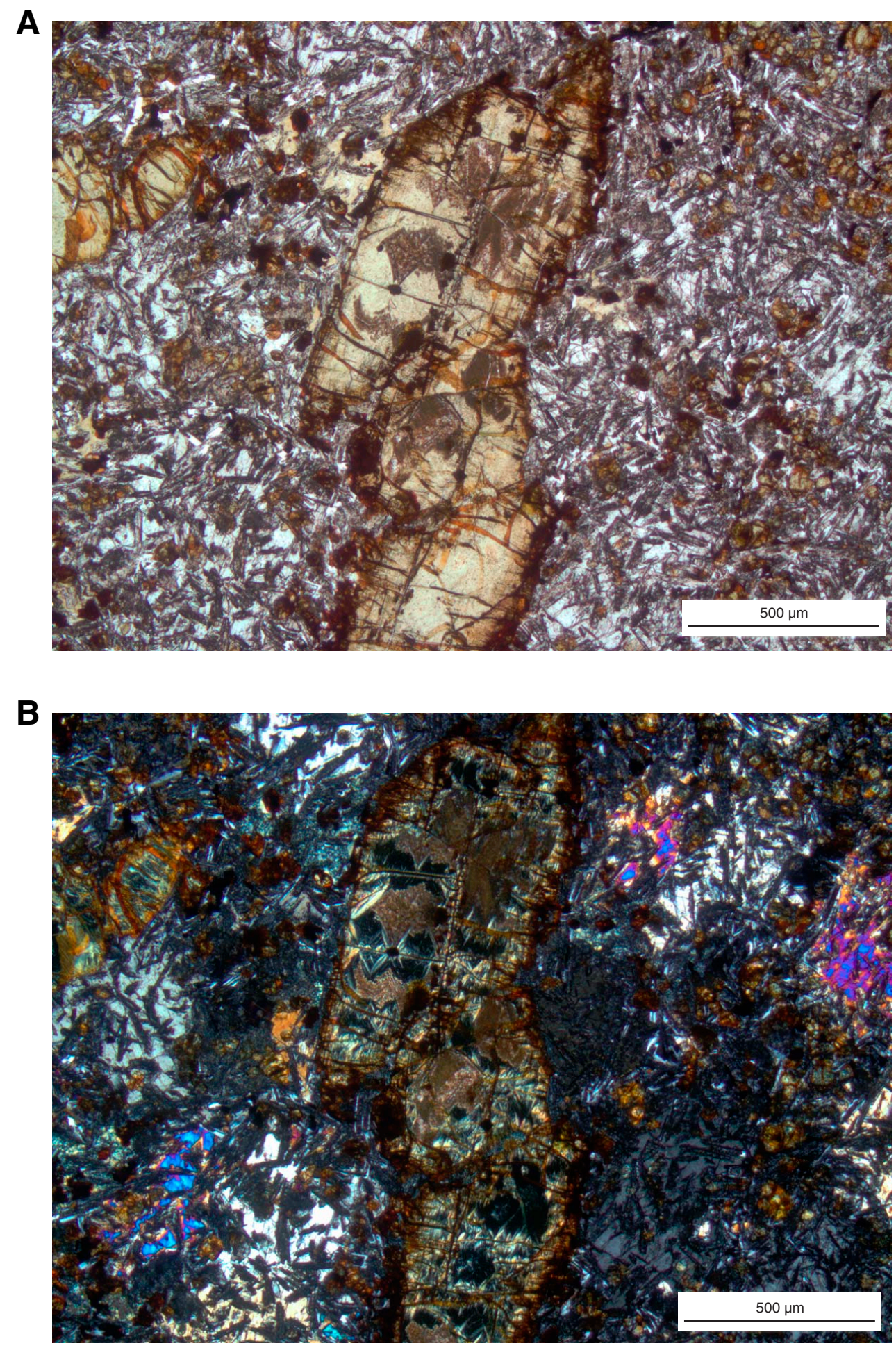
Figure F45. Photomicrograph of chlorite and calcite veins and their relationships to groundmass alteration, Hole U1349A (Thin Section 235; Sample 324-U1349A-12R-3, 32-34 cm). 1 = alteration of olivine to iddingsite and formation of clay minerals \pm Fe oxyhydroxides around vesicle, $2=$ infilling of vesicles with calcite, $3=$ chlorite vein, 4 = calcite veins. Plane-polarized light.

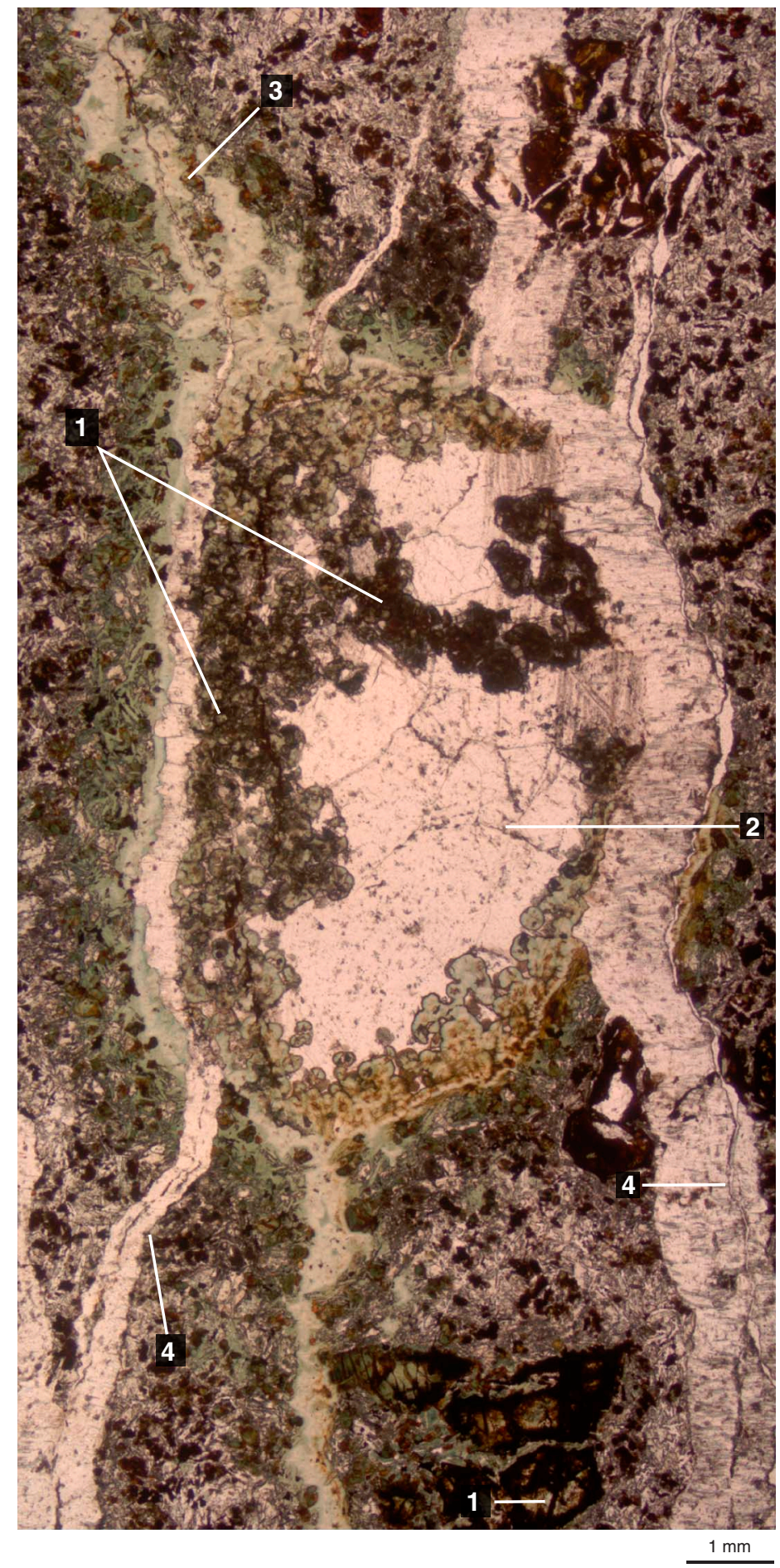


Figure F46. A, B. Photomicrographs of olivine phenocrysts altered to saponite, calcite, and first order birefringence serpentine along the fractures of the grain, Hole U1349A (Thin Section 253; Sample 324-U1349A-15R-3, $115-118 \mathrm{~cm})$. A is under plane-polarized light; B is under cross-polarized light.
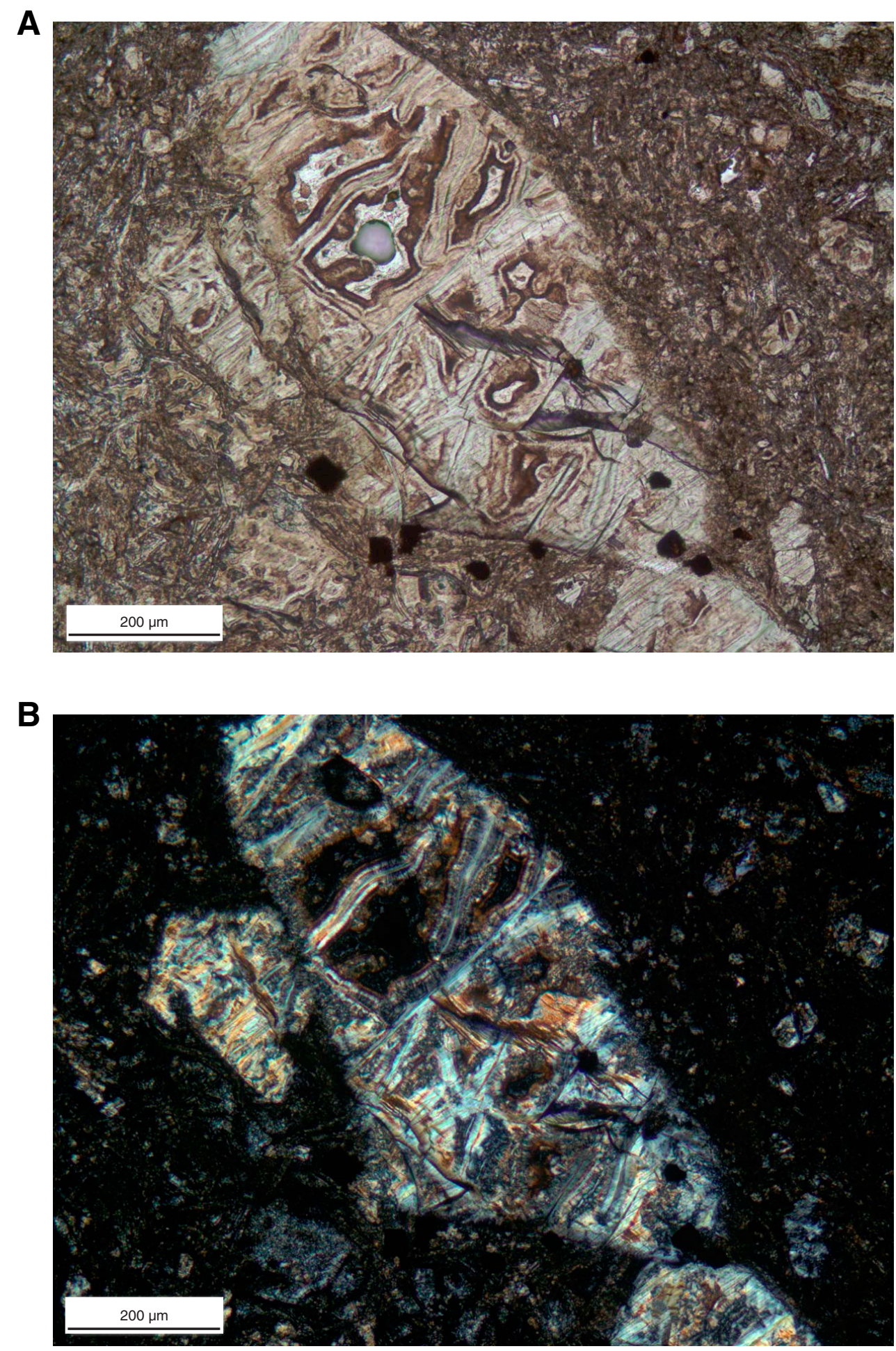
Figure F47. A. Section-half core image of basaltic breccia in Unit V cemented by light green clays and calcite, Hole U1349A (Sample 324-U1349A-16R-6, 55-62 cm). B. Photomicrograph of florets of light green clay intergrown with Fe oxyhydroxides and cemented with calcite (Thin Section 261; Sample 324-U1349A-16R-6, 56$61 \mathrm{~cm})$. C. Photomicrograph of light green clay saponite and calcite that cements the highly altered basaltic clasts in Unit V (Thin Section 253; Sample 324-U1349A-15R-3, 115-118 cm). B and C are under plane-polarized light.
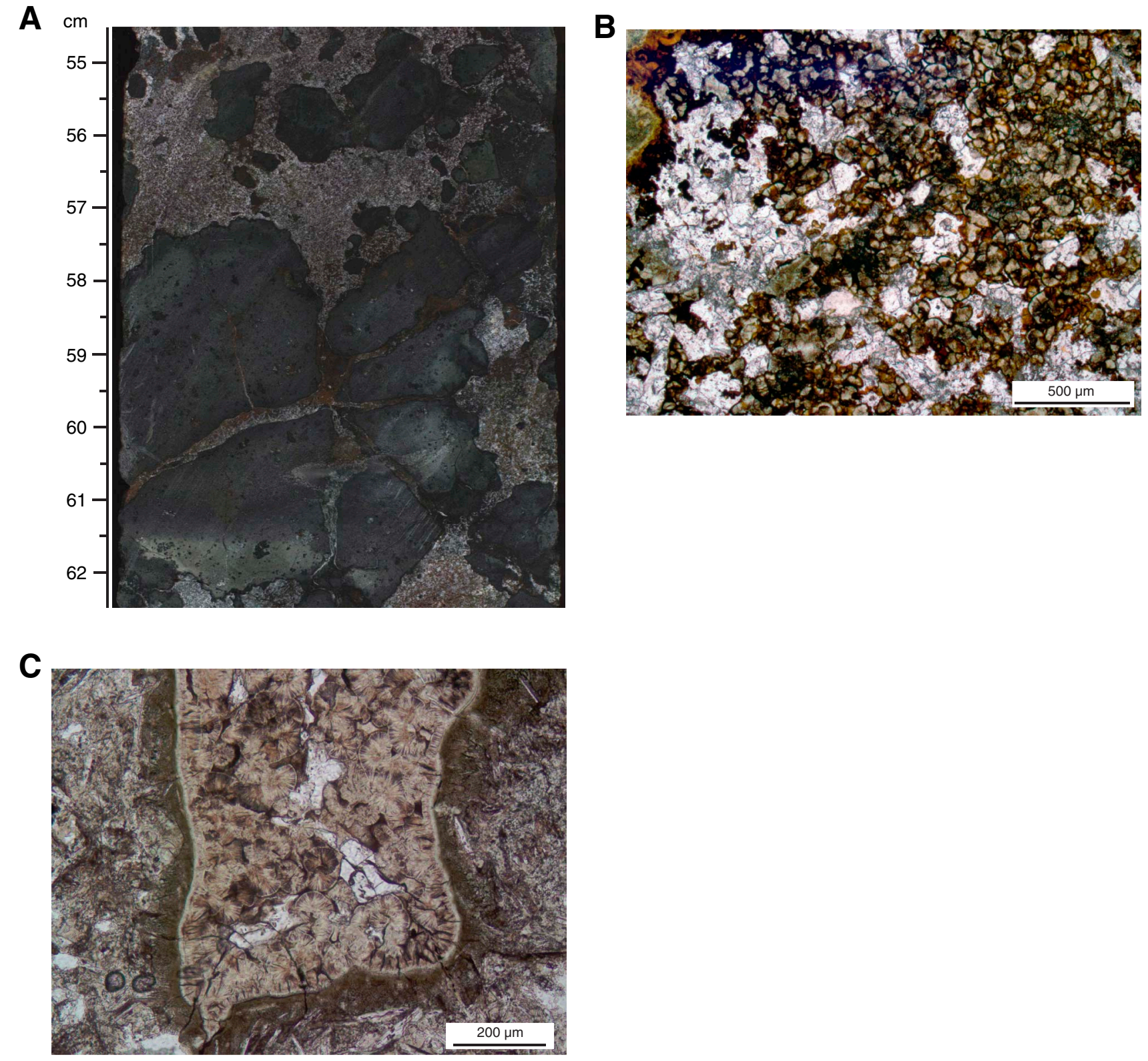
Figure F48. A. Photomicrograph of cross-fiber calcite vein containing saponite and cutting crystalline calcite veins, Hole U1349A (Thin Section 221; Sample 324-U1349A-10R-3, 43-48 cm). B. Close-up image of archivehalf core with a calcite vein being cut by a vein of orange clays (Sample 324-U1349-14R-6, 48-49 cm). C. Photomicrograph of a vein in which Fe oxyhydroxides are overgrown by brown saponite, which is in turn overgrown by green nontronite and blue-green celadonite and subsequently is cemented by calcite (Thin Section 246; Sample 324-U1349A-14R-4, 50-56 cm). D. Close-up image of archive-half core with a vein in which green clays are being replaced by orange oxidized clays (Sample 324-U1349A-16R-5, 115-116 cm). A and C are under plane-polarized light.
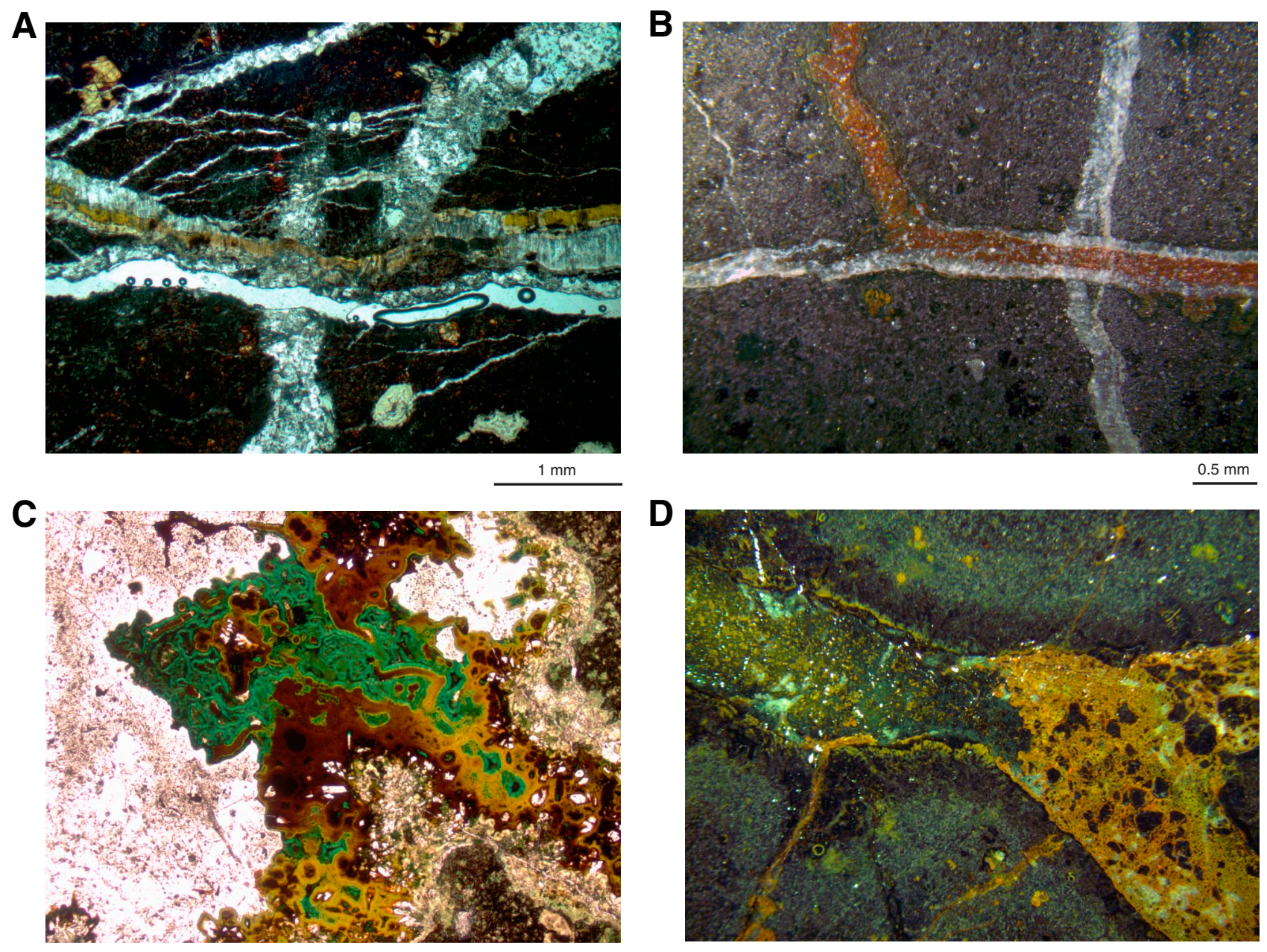
Figure F49. A, B. Photomicrographs of a calcite-filled vesicle with tabular zeolite crystals along the rim, Hole U1349A (Thin Section 221; Sample 324-U1349A-10R-3, 43-48 cm). C. Photomicrograph of a saponite-filled vesicle (Thin Section 210; Sample 324-U1349A-9R-3, 6-9 cm). D. Photomicrograph of a zeolite-filled vesicle (Thin Section 238; Sample 324-U1349A-13R-1, 29-32 cm). A is under plane-polarized light; B, C, and D are under cross-polarized light.
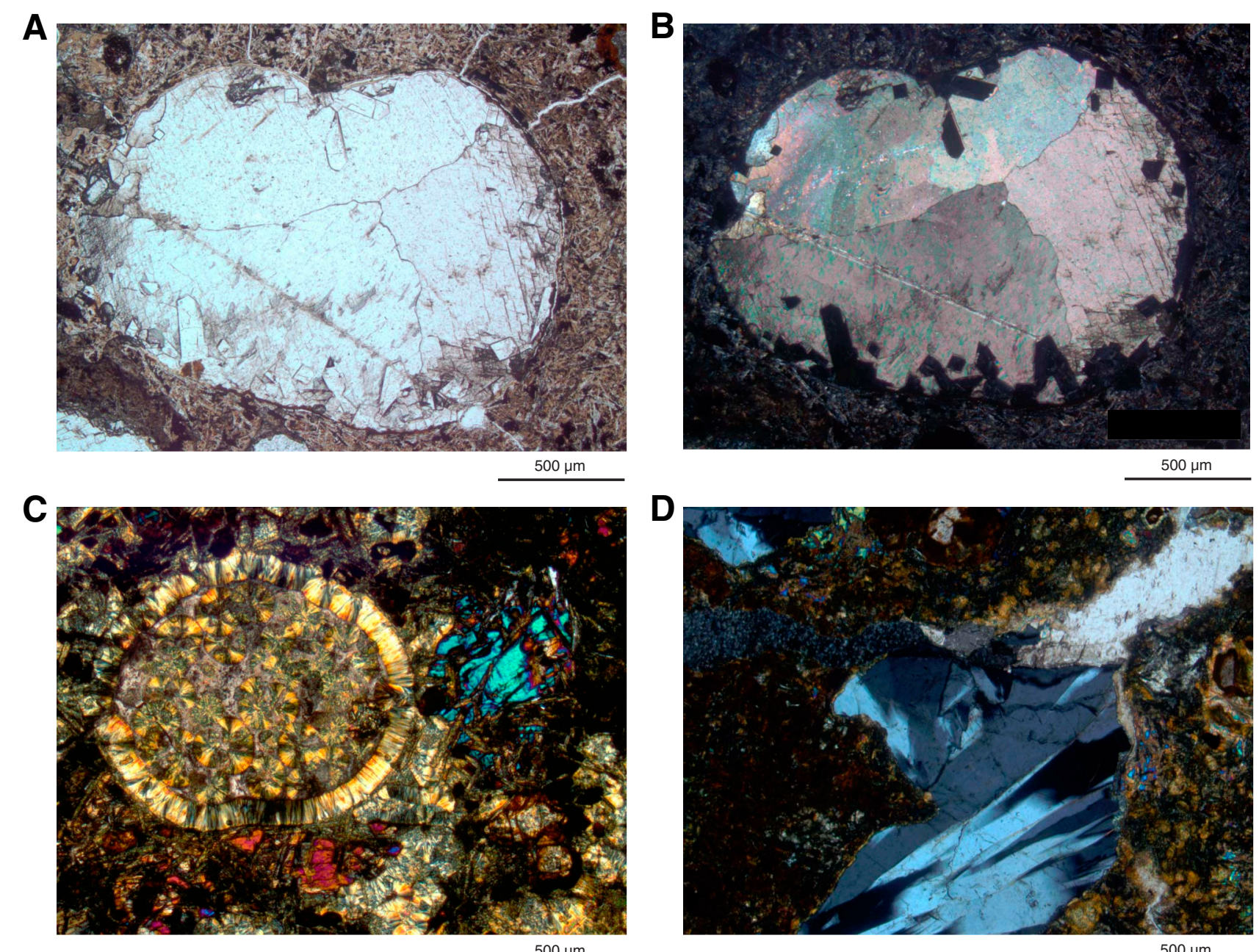

$500 \mu \mathrm{m}$ 
Figure F50. Core images of five sheet flow structures showing their three parts: lava upper crust, lava core, and basal zone, Hole U1349A (Sections 324-U1349A-9R-1 through 10R-5). A, B is lava upper crust, C is lava core, and $\mathrm{D}$ is basal zone.
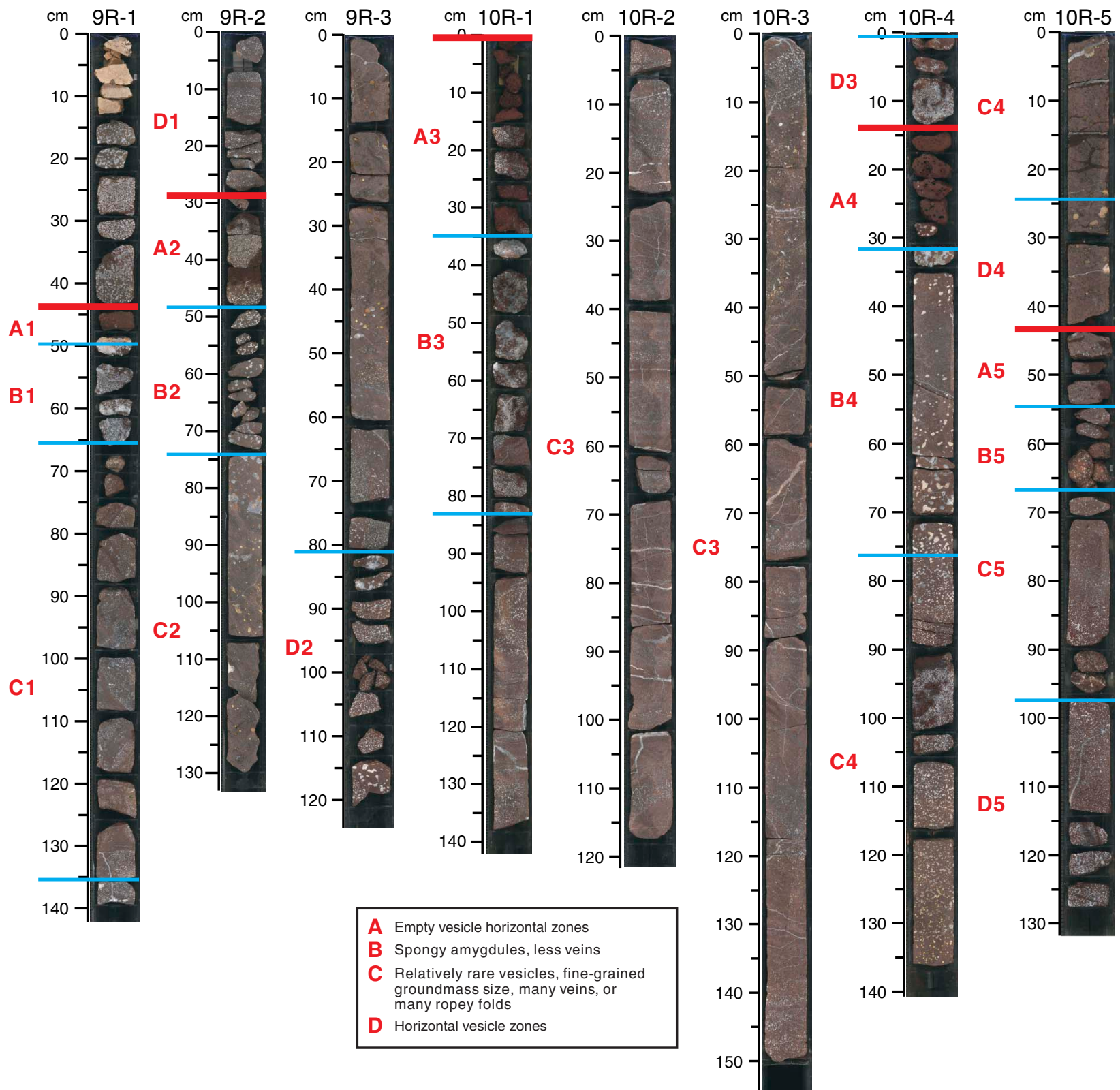

A Empty vesicle horizontal zones

B Spongy amygdules, less veins

C Relatively rare vesicles, fine-grained groundmass size, many veins, or many ropey folds

D Horizontal vesicle zones 
Figure F51. Core images of flow structures, Hole U1349A. Arrows = possible flow lines. A. Ropey folds in the lava core (interval 324-U1349A-11R-3, 102-120 cm). B. Vesicle zonation caused by flow or segregation (interval 324-U1349A-11R-3, 68-90 cm).

A

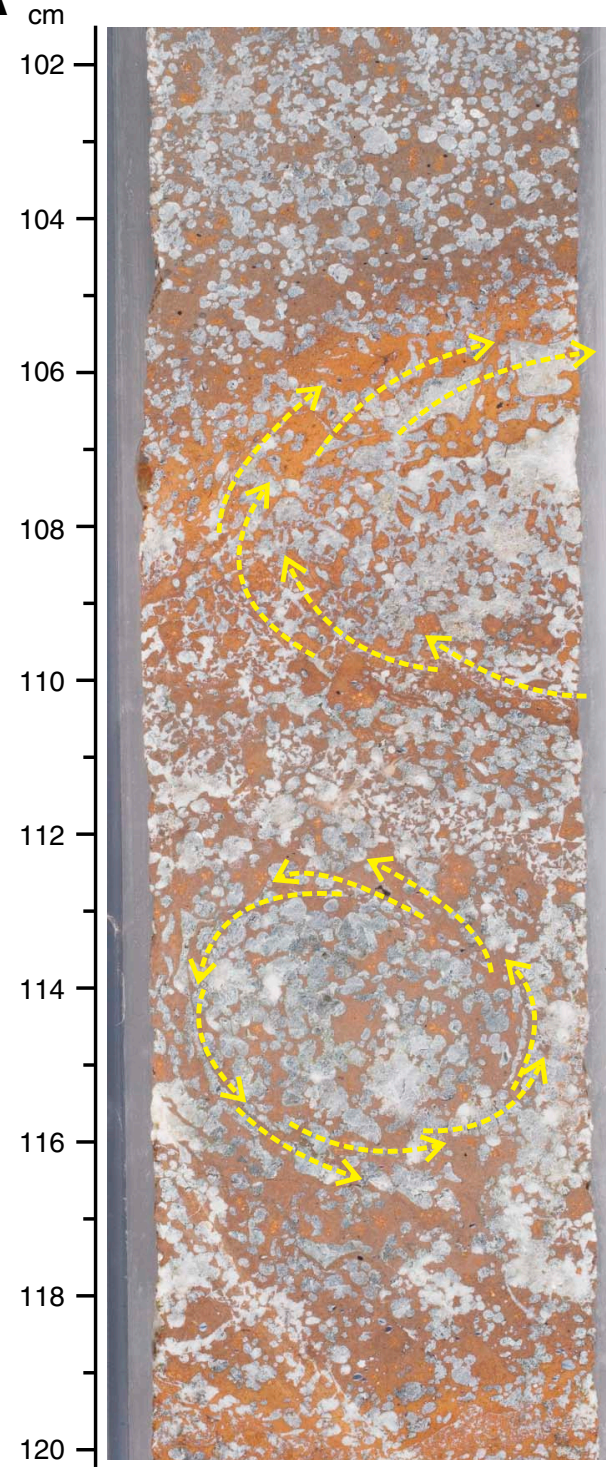

B

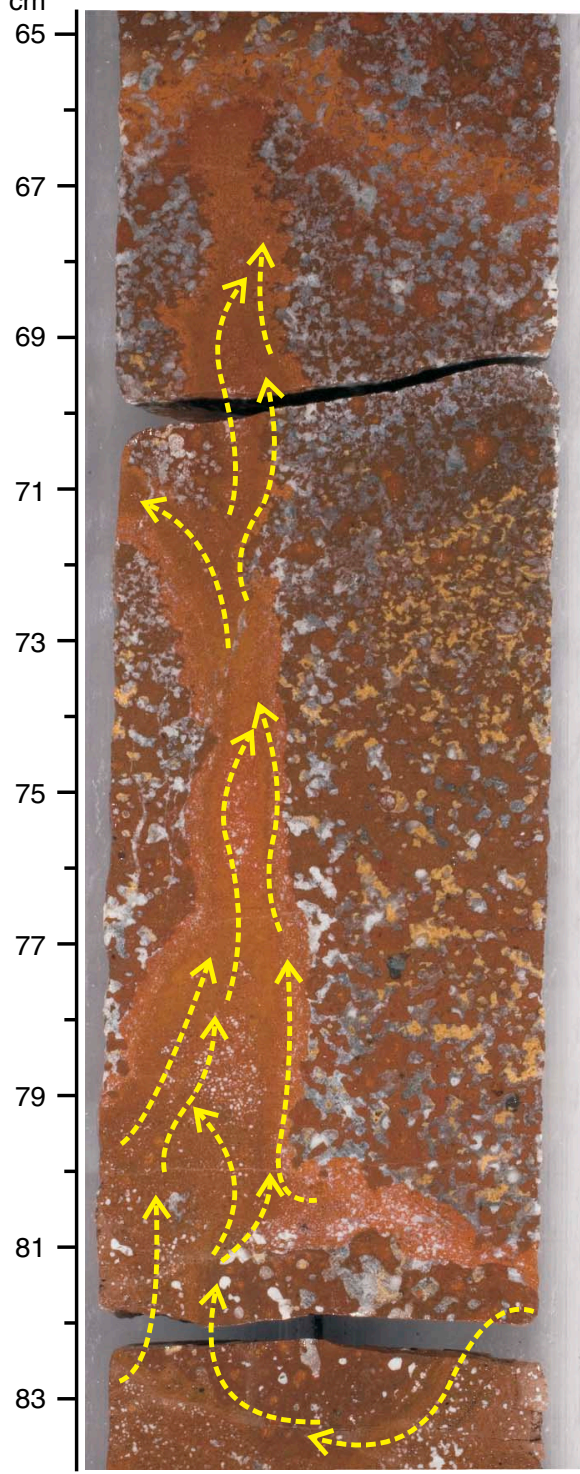


Figure F52. Core images of pillow lava with continuous glassy rims, Hole U1349A. Yellow dotted lines = pillow margins. A. Interval 324-U1349A-16R-6, 72-82 cm. B. Interval 324-U1349A-16R-7, 1-10 cm.

A

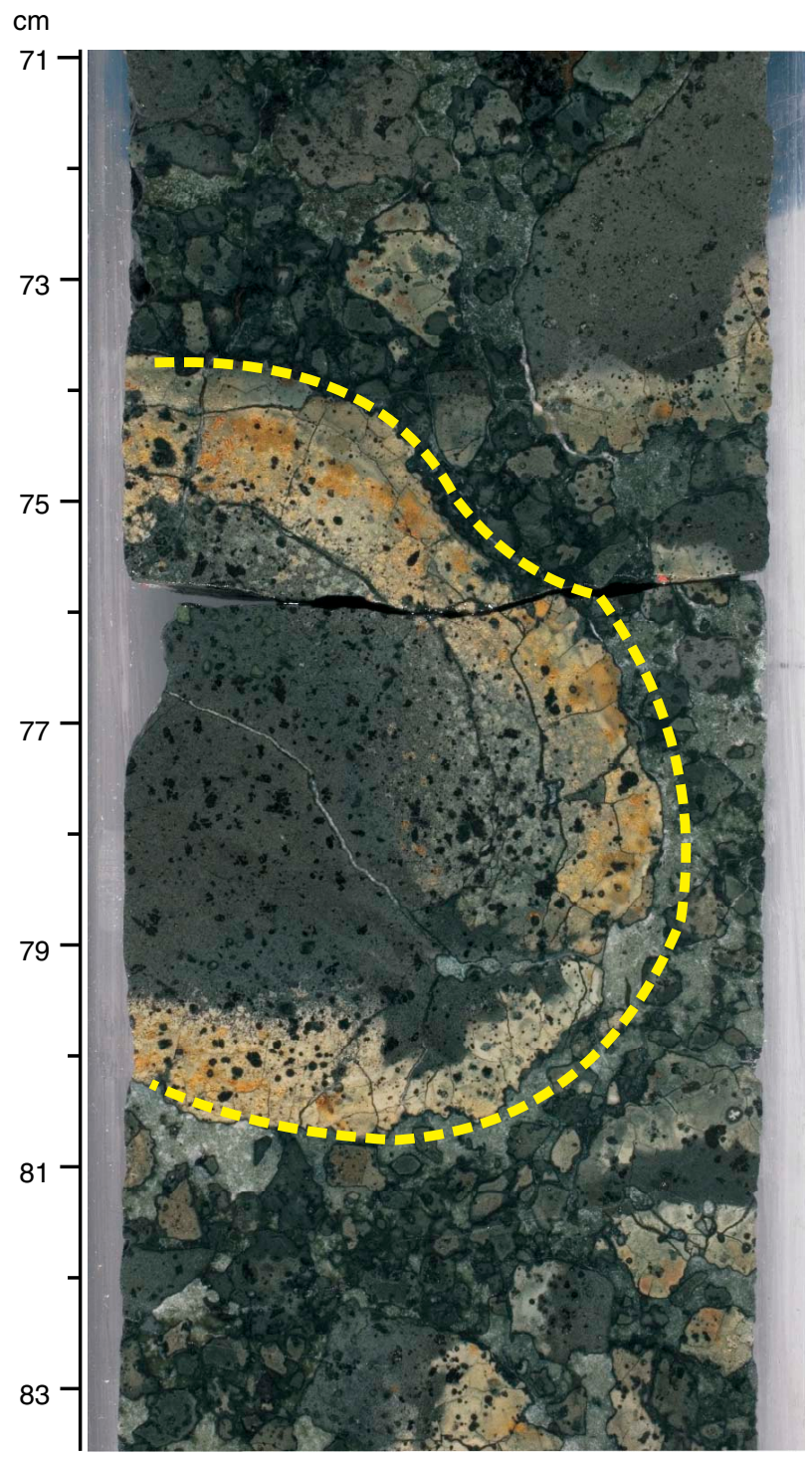

B

$\mathrm{cm}$

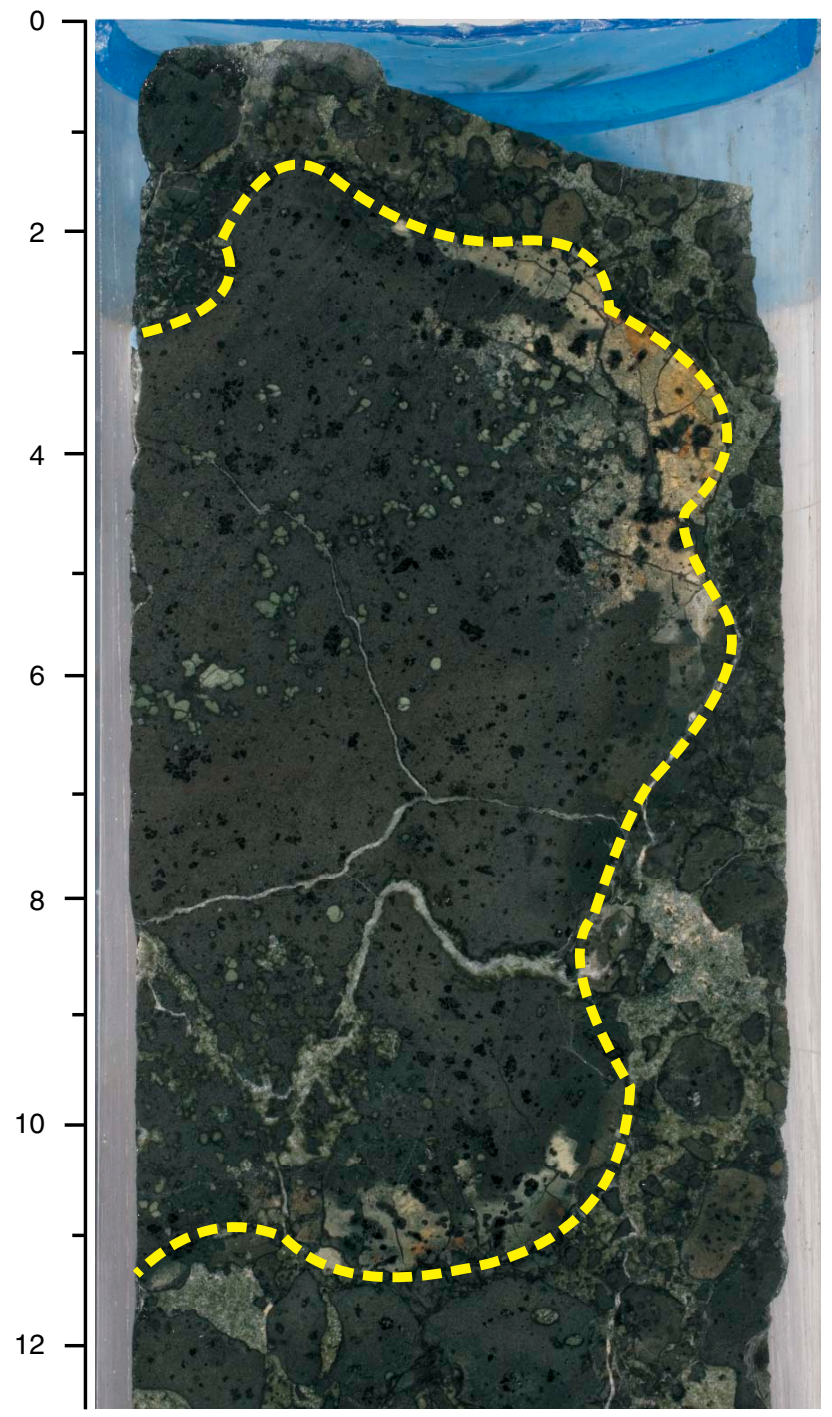


Figure F53. Photomicrographs of vein textures in Hole U1349A basalts. A, B. Cross-fibers composed of (A) needlelike and (B) spherulitic zeolites growing perpendicular to vein walls (Thin Section 260; Sample 324U1349A-16R-6, 7-12 cm). C. Polycrystalline texture mainly displayed by calcite in veins (Thin Section 254; Sample 324-U1349A-15R-4, 104-110 cm). D. Intravenous vein texture displayed by disorderedly aligned calcites or zeolites (Thin Section 249; Sample 324-U1349A-14R-5, 53-54 cm). Cross-polarized light.
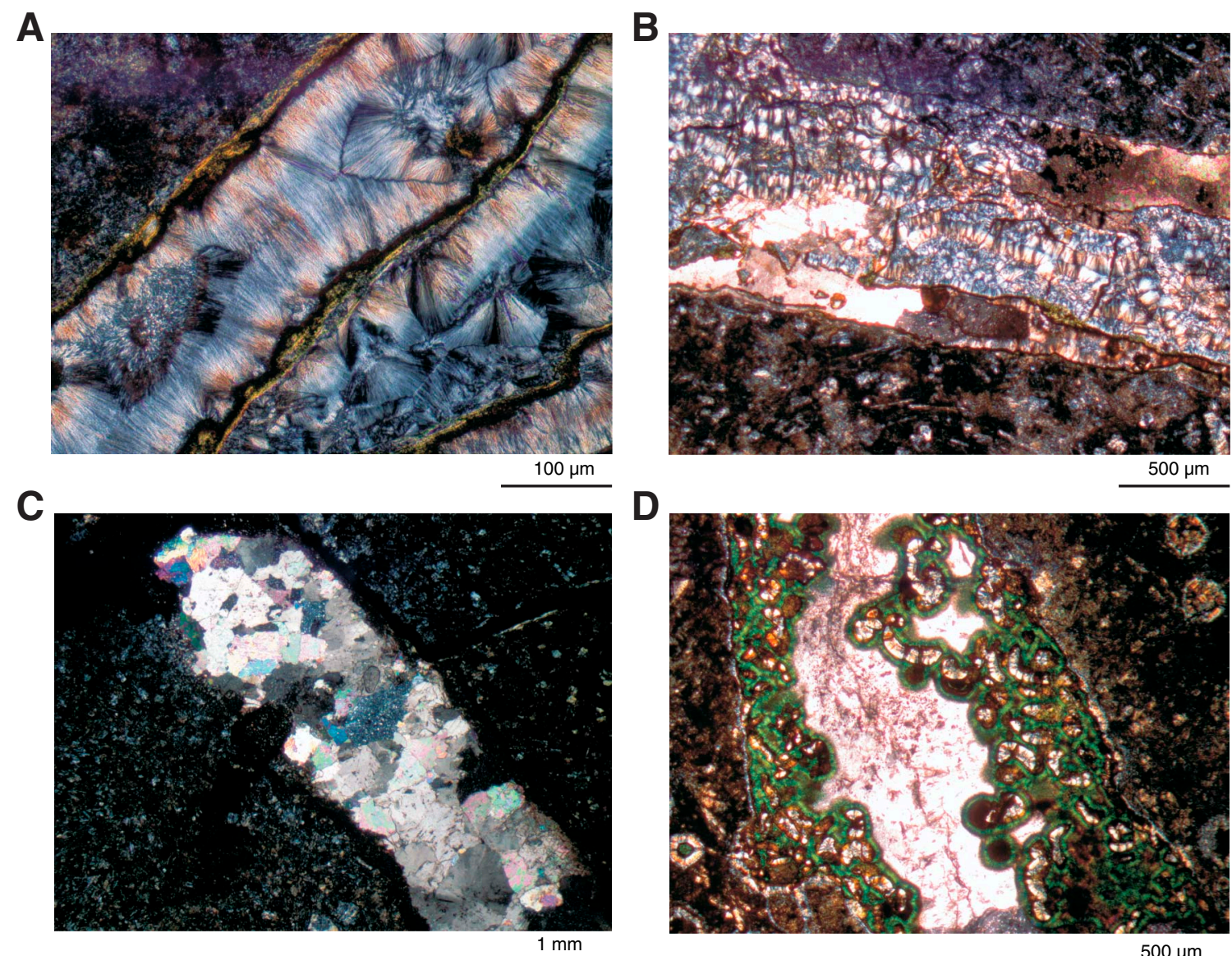
Figure F54. Core images of vein geometry, Hole U1349A. A. Network veins (interval 324-U1349A-10R-2, 45$59 \mathrm{~cm}$ ). B. En echelon veins (interval 324-U1349A-9R-1, 126-139 cm) C. Conjugate veins (interval 324U1349A-12R-2, 107-116 cm). D. Pull-apart veins (interval 324-U1349A-16R-5, 61-74 cm). E. Branched veins (interval 324-U1349A-13R-1, 123-132 cm). F. Anastomosing veins (interval 324-U1349A-12R-3, 17-35 cm). G. Parallel veins (interval 324-U1349A-10R-2, 68-85 cm). H. Ribbon veins (interval 324-U1349A-13R-5, 120$134 \mathrm{~cm})$.
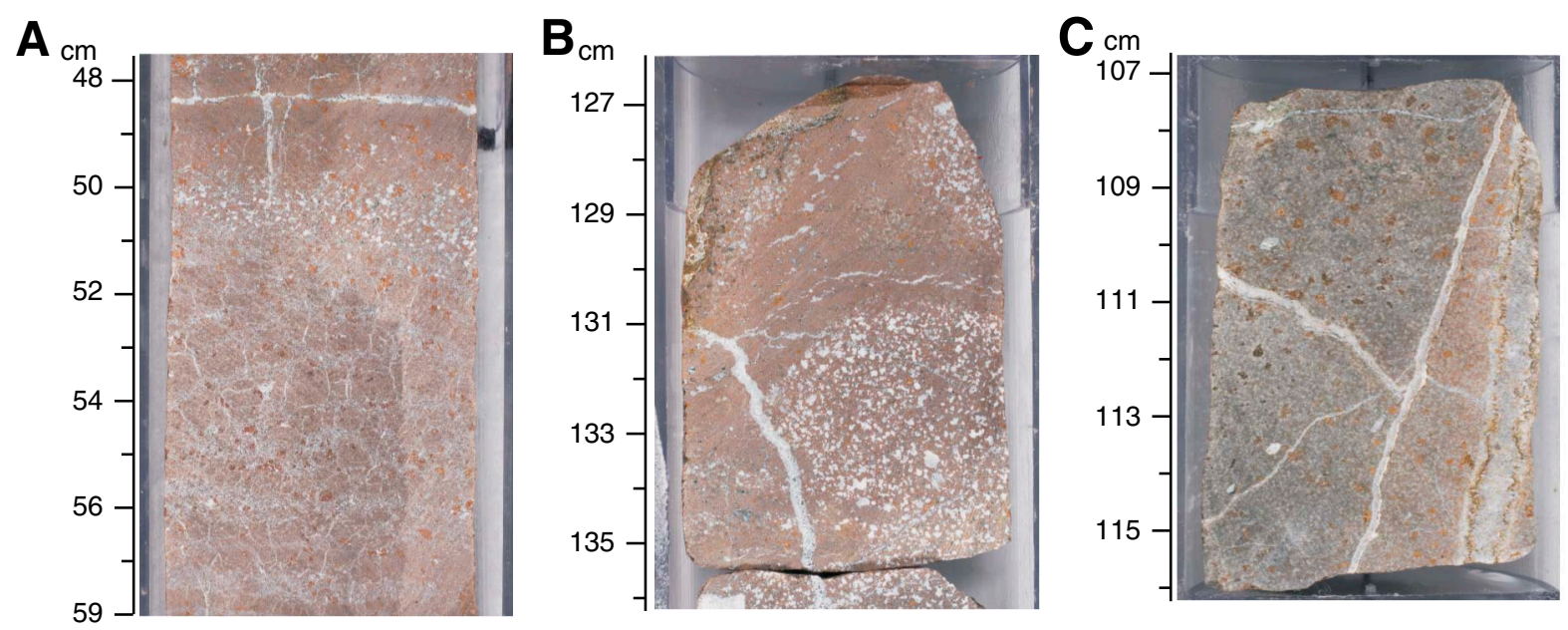

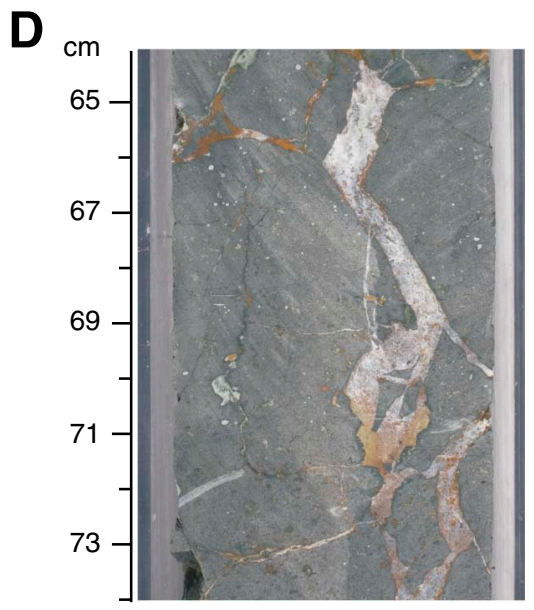

$\mathbf{E} \mathrm{cm}$

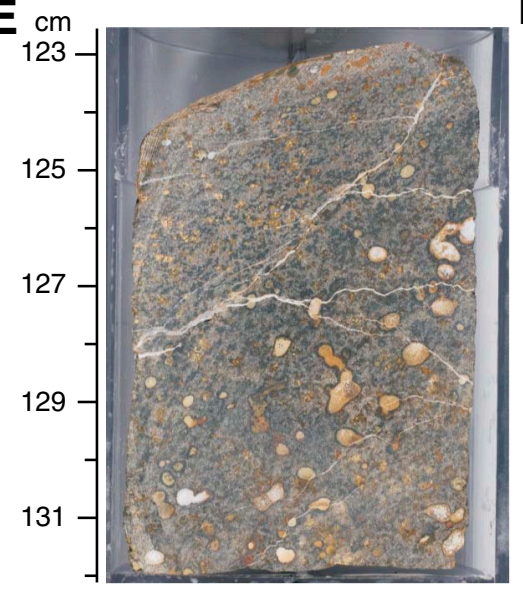

G $\mathrm{cm}$

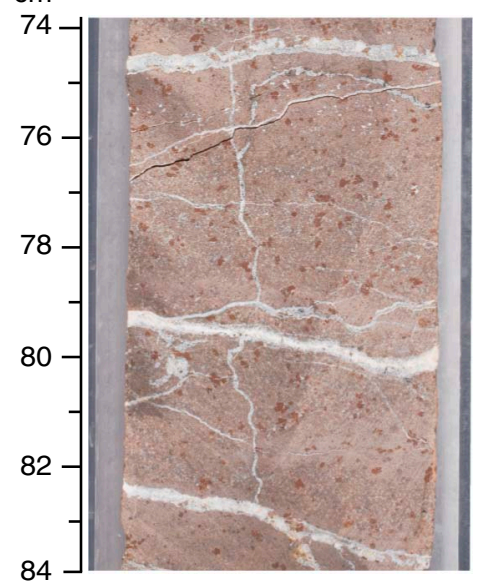

H

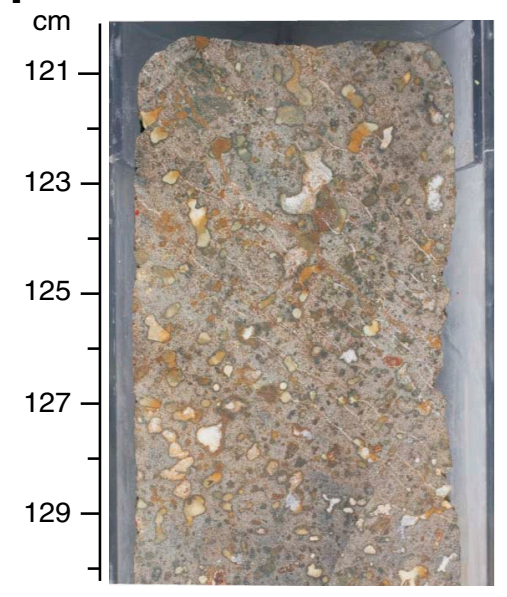

$F_{\mathrm{cm}}$

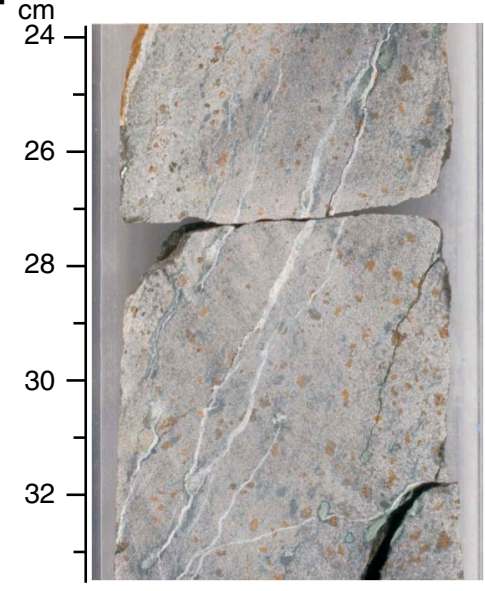


Figure F55. Photomicrographs of vein crosscutting relationships, Hole U1349A. A, B. Core images of horizontal veins cutting subvertical veins in intervals (A) 324-U1349A-10R-2, 25-38 cm, and (B) 324-U1349A-10R-2, 68$85 \mathrm{~cm}$. C. Photomicrographs of first generation calcite veins (V1) cut by third generation zeolite veins (V2) and second generation glassy veins (V3). D. Second generation zeolite veins (V2) cut by third generation glassy veins (V3) (Thin Section 221; Sample 324-U1349A-10R-3, 43-48 cm). Cross-polarized light.

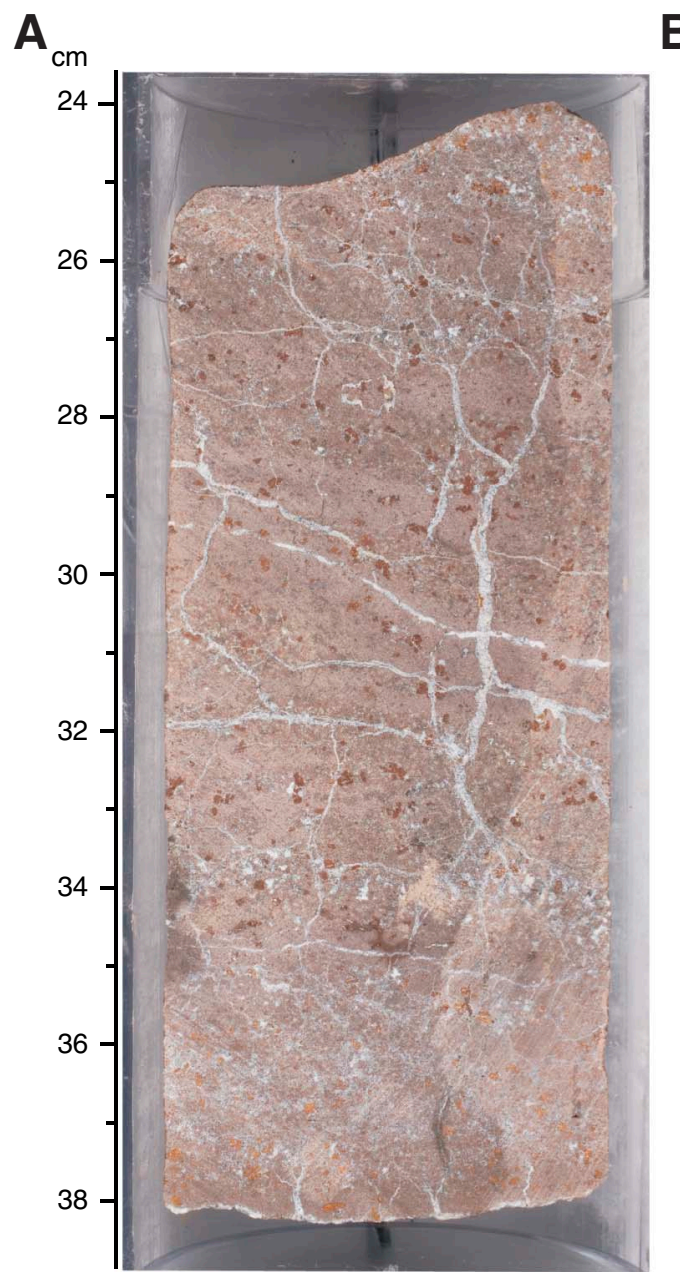

$B$
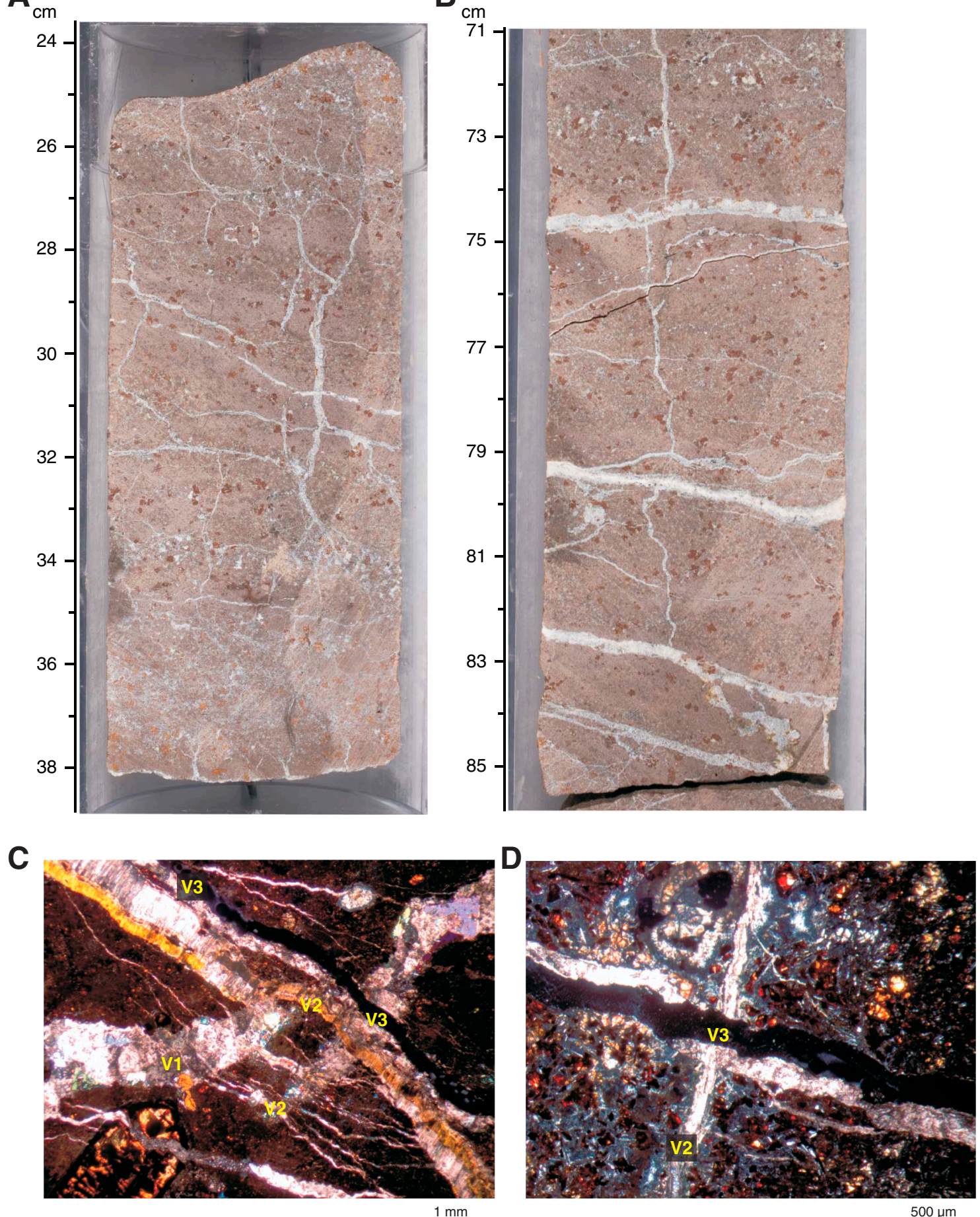

$500 \mu \mathrm{m}$ 
Figure F56. Relationships among groundmass grain size, vesicularity, and dip of vein, Hole U1349A.

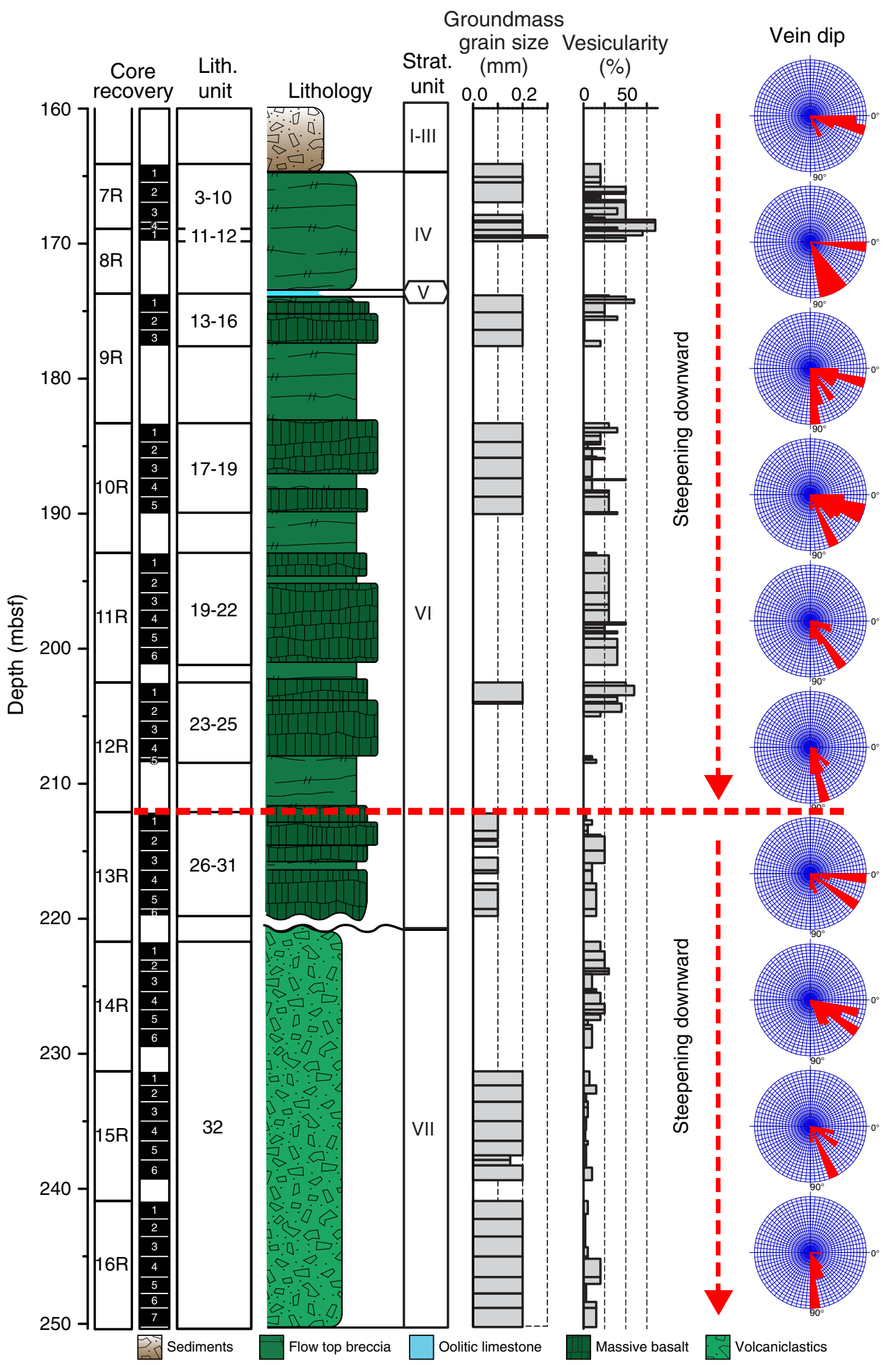


Figure F57. A. Core image of reddish brown breccias above interval 324-U1349A-13R-4, 1-96 cm, Hole U1349A. B, C. Core images of greenish gray volcanic autobreccias (B) above interval 324-U1349A-14R-5, 72-89 $\mathrm{cm}$, and (C) at interval 324-U1349A-15R-3, 79-88 cm. D. Photomicrograph of greenish gray, microscopic-scale volcanic autobreccias (Thin Section 254; Sample 324-U1349A-15R-4, 104-110 cm). Cross-polarized light.

$\mathbf{A}_{\mathrm{cm}}$

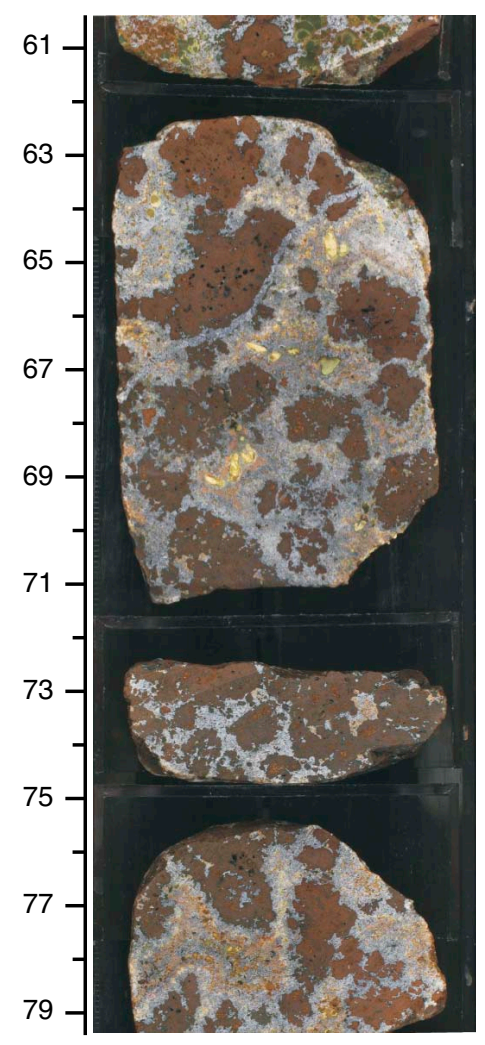

$\mathbf{B}_{\mathrm{cm}}$

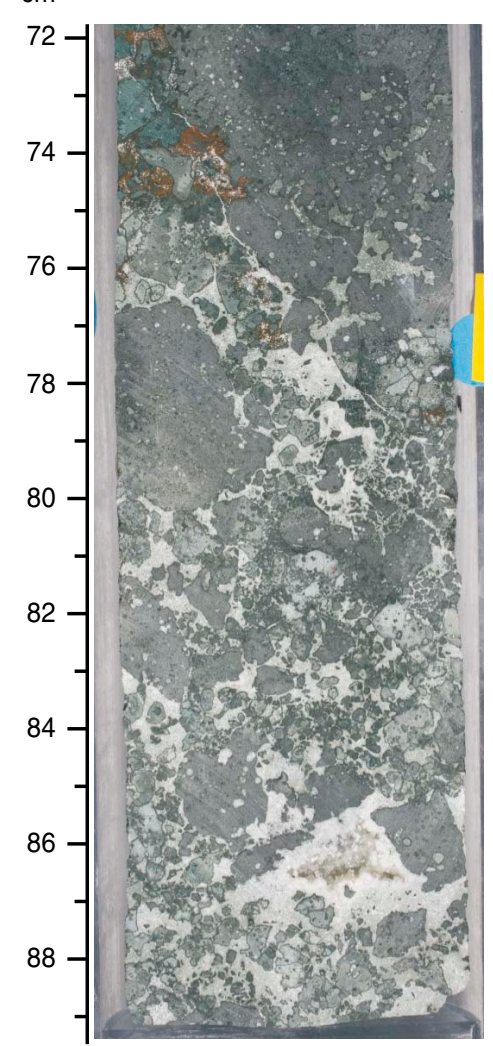

C
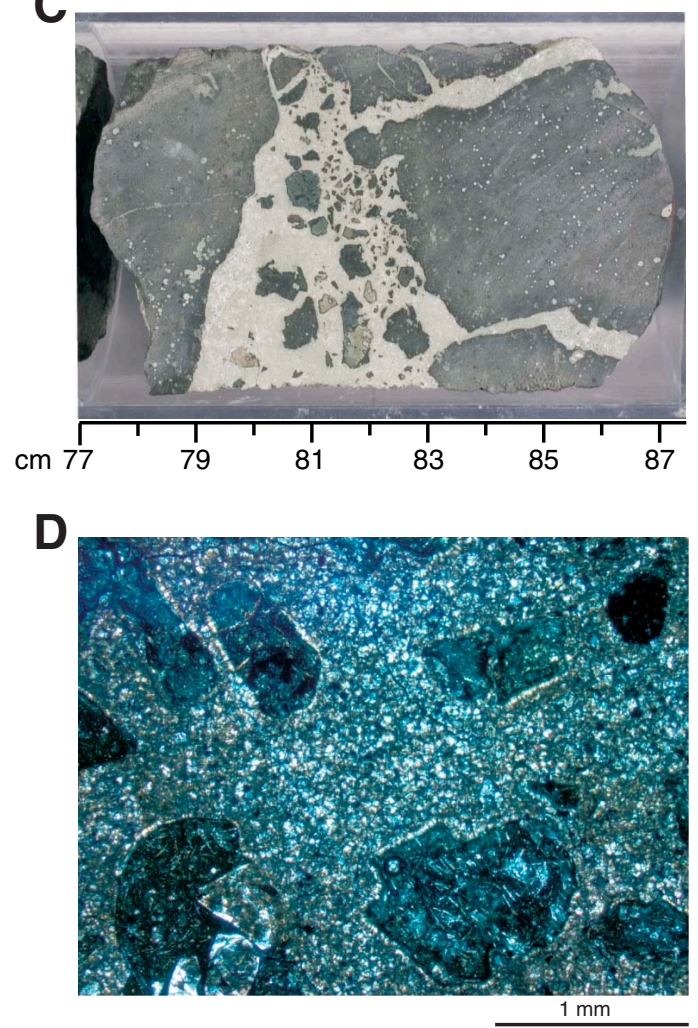
Figure F58. A. Diagram of total alkalis vs. silica with Le Maitre et al.'s (1989) classification of volcanic rock types. Heavy dashed line = division of data for tholeiitic and alkalic lavas of Hawaii (Macdonald and Katsura, 1964; Macdonald, 1968). Values are normalized to $100 \mathrm{wt} \%$ totals. Data for the highly vesicular, carbonate-rich split of Sample 324-U1349A-11R-5 (Piece 1A, 12-15 cm) are off the graph and thus not shown; nor are data for two carbonate-rich veins from Site U1346 (see "Geochemistry" in the "Site U1346" chapter). Also not shown are data for the melt segregation and altered glass of Site U1347. OJP = Ontong Java Plateau (data of Tejada et al., 1996, 2002; Fitton and Godard, 2004), EPR = East Pacific Rise (data of Sinton et al., 1991; Bach et al., 1994; Mahoney et al., 1994), Nazca-ESC = Nazca Ridge and Easter Seamount Chain (Ray et al., unpubl. data). B. $\mathrm{K}_{2} \mathrm{O}$ vs. loss on ignition (LOI).
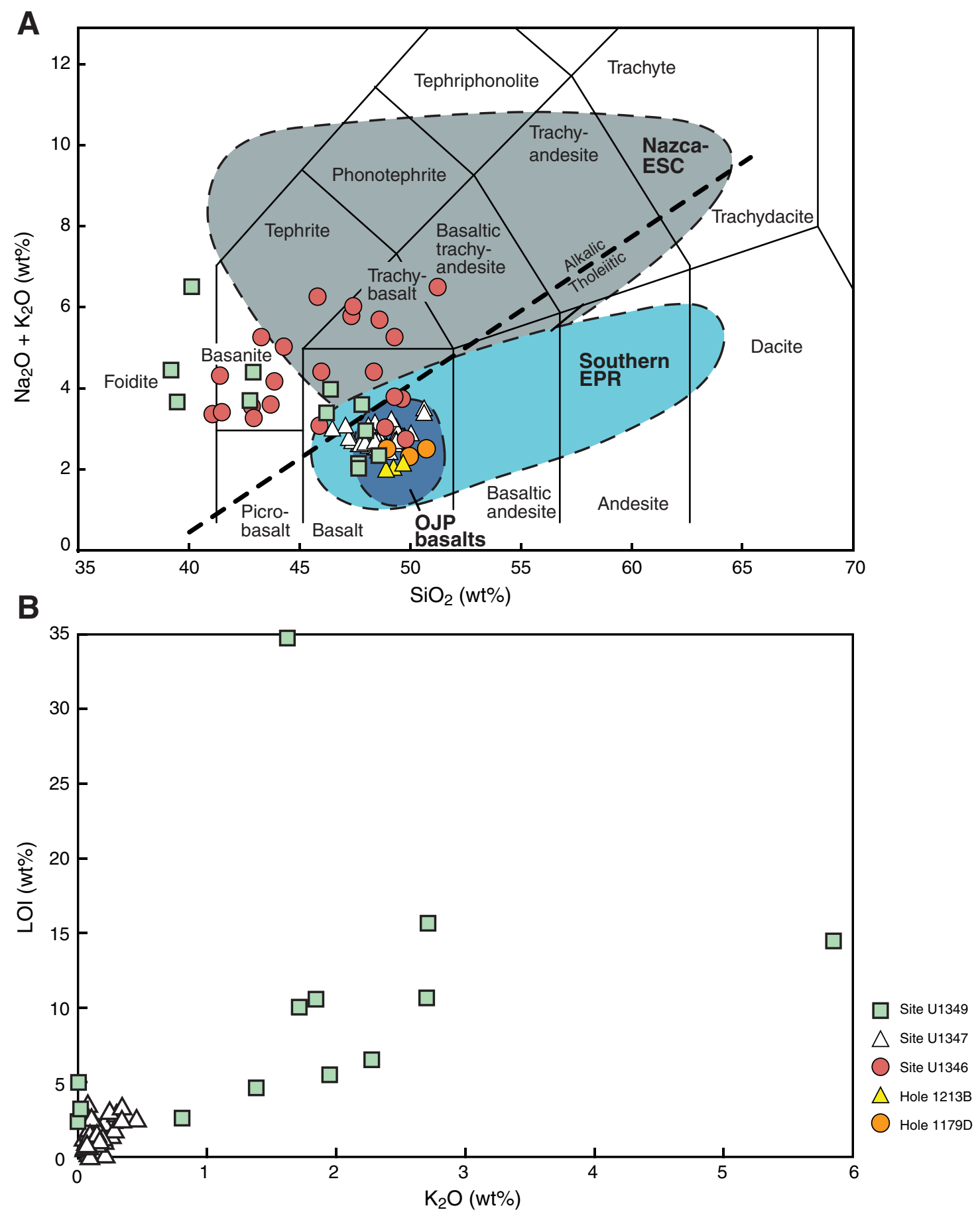
Figure F59. Diagram of $\mathrm{TiO}_{2}$ vs. (A) $\mathrm{Mg \# ,} \mathrm{(B)} \mathrm{Zr}$, (C) $\mathrm{Ni}$, (D) $\mathrm{Cr}$, and (E) Sc. $\mathrm{Mg \#}=100 \times\left[\mathrm{Mg}^{2+} /\left(\mathrm{Mg}^{2+}+\mathrm{Fe}^{2+}\right)\right]$, assuming that $\mathrm{Fe}_{2} \mathrm{O}_{3} / \mathrm{FeO}=0.15$. Site U1349 sample with the lowest $\mathrm{TiO}_{2}$ value is the split of carbonate-dominated "foamy" lava from Sample 324-U1349A-11R-5 (Piece 1A, 12-15 cm). Data for two carbonate-rich veins from Site U1346 are not shown (see "Geochemistry" in the "Site U1346" chapter); nor are data for the melt segregation and altered glass of Site U1347 (see "Geochemistry" in the "Site U1347" chapter). OJP = Ontong Java Plateau (data from Tejada et al., 1996, 2002; Fitton and Godard, 2004), EPR = East Pacific Rise (data from Sinton et al., 1991; Bach et al., 1994; Mahoney et al., 1994), Nazca-ESC = Nazca Ridge and Easter Seamount Chain (data from Ray et al., 2010).

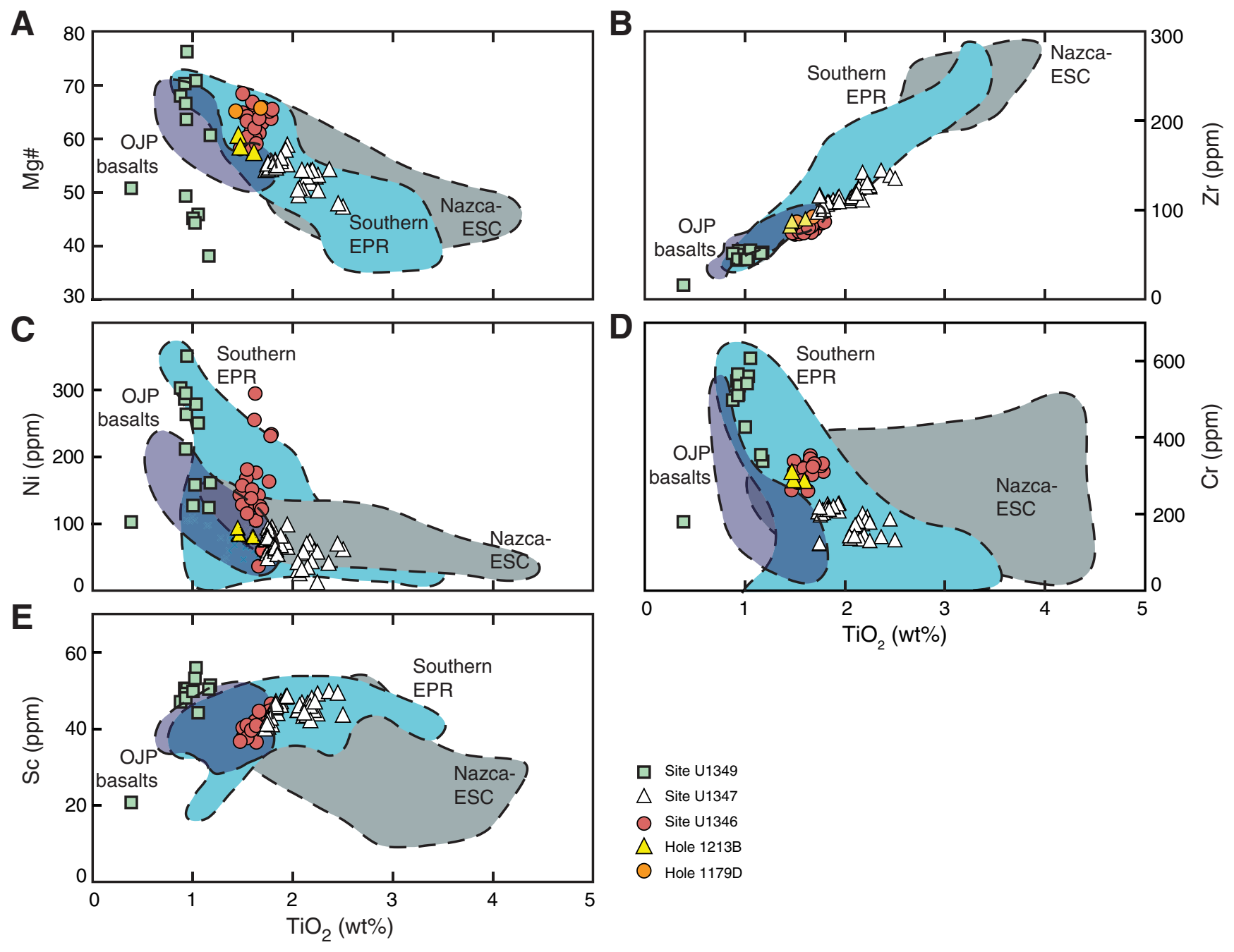


Figure F60. Whole-round physical property data summary, Hole U1349A. For more details about data filtering, see "Physical properties" in the "Methods" chapter. NGR = natural gamma radiation, MS = magnetic susceptibility, GRA = gamma ray attenuation.

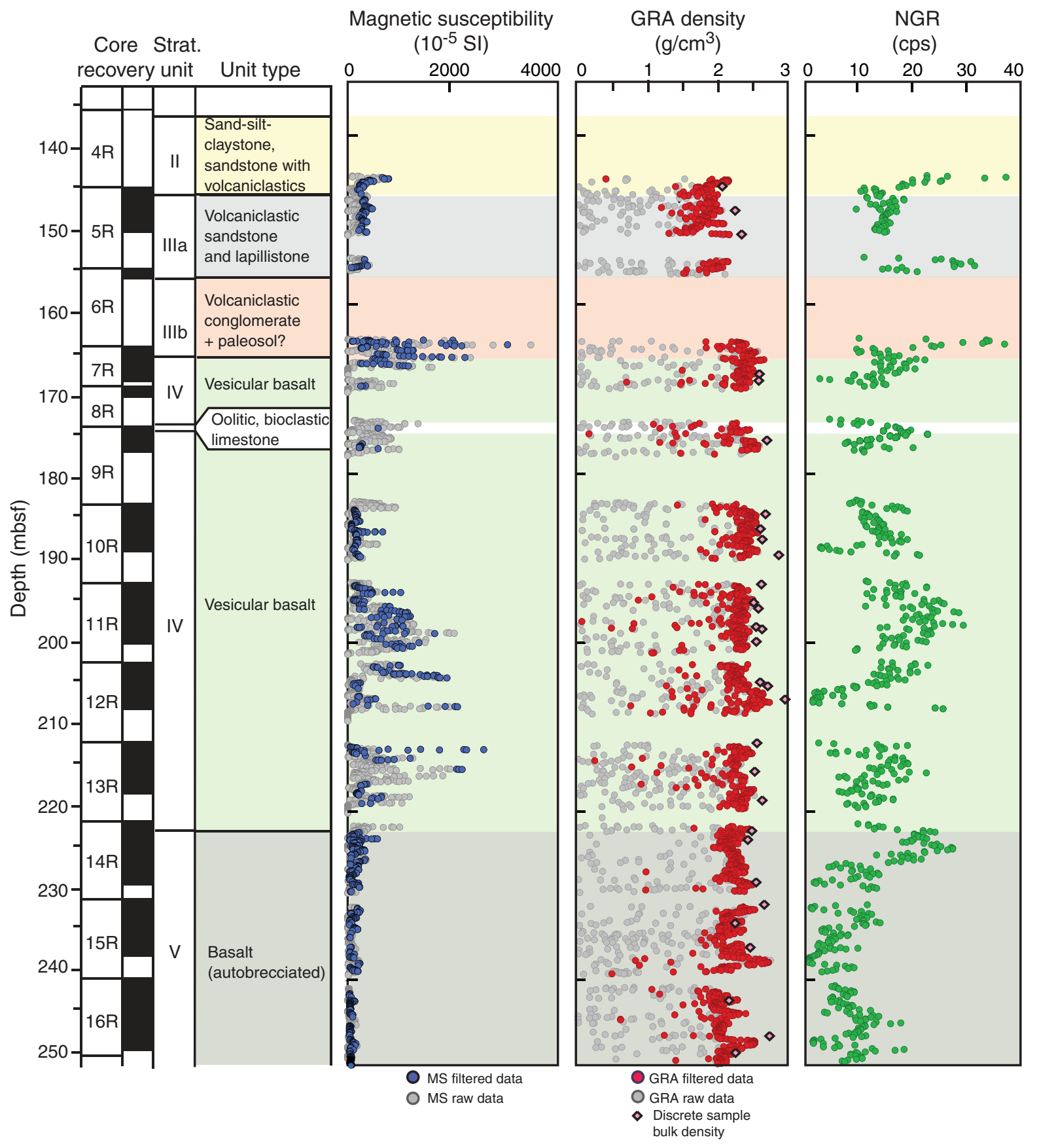


Figure F61. Selected discrete sample measurements, Hole U1349A. Red dashed line connects measurements of bulk density for ease of comparison with $P$-wave velocity measurements.

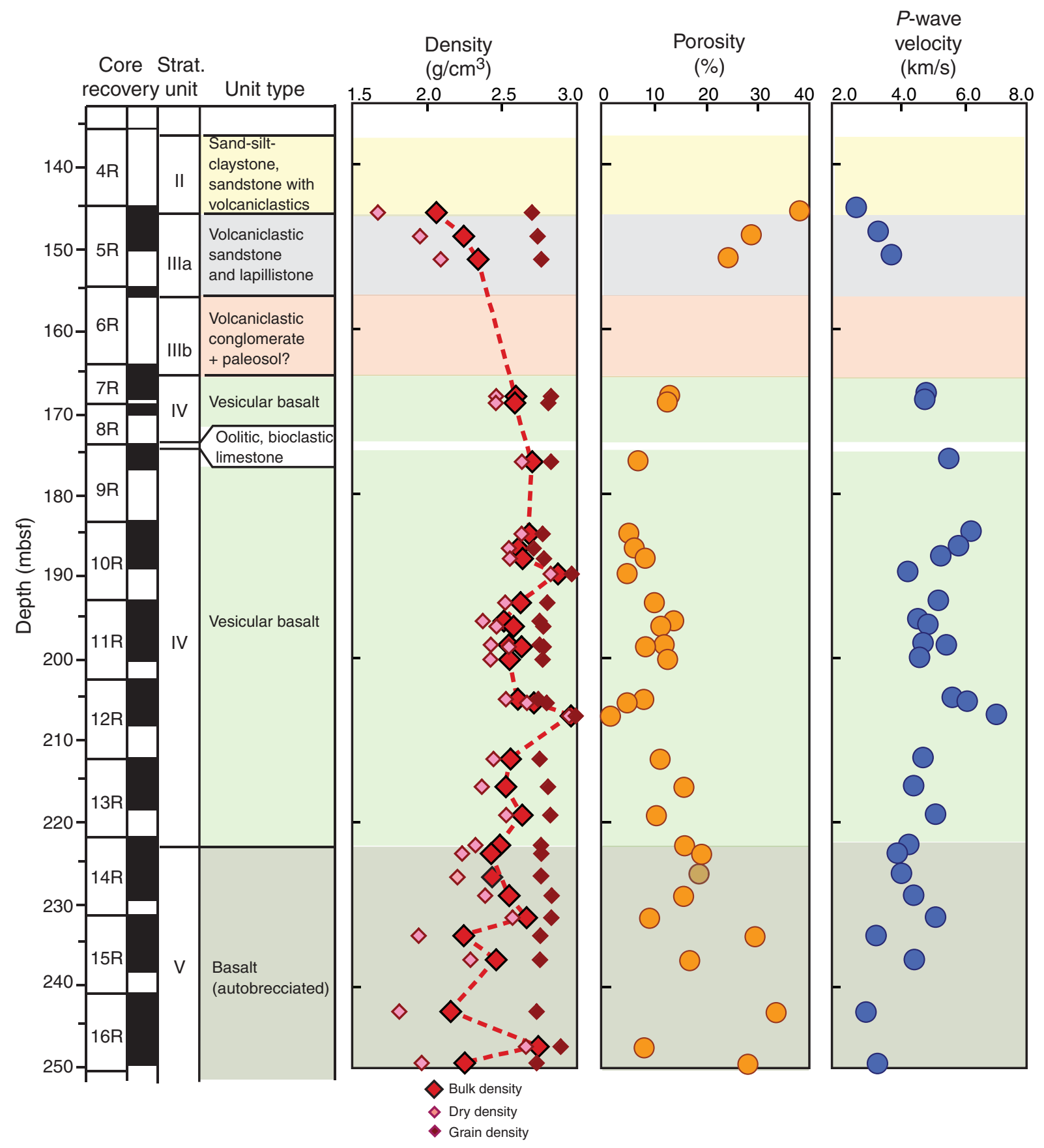


Figure F62. Plots of discrete measurements of $P$-wave velocity vs. (A) bulk density and (B) porosity, Hole U1349A. See "Sedimentology" and "Igneous petrology" for descriptions of stratigraphic units.
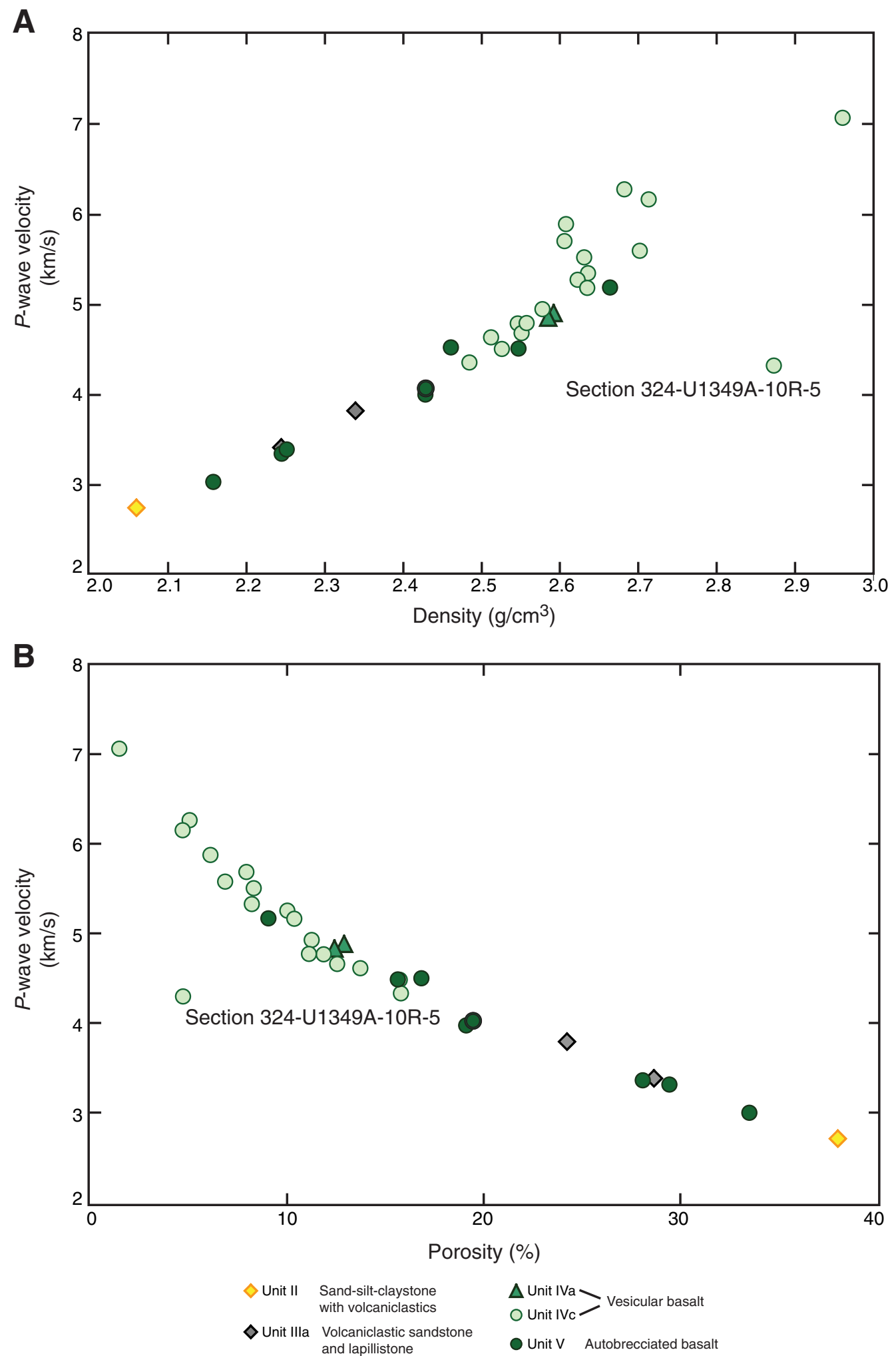
Figure F63. Thermal conductivity measurement summary, Hole U1349A. Stratigraphic units are described in "Sedimentology" and "Igneous petrology."

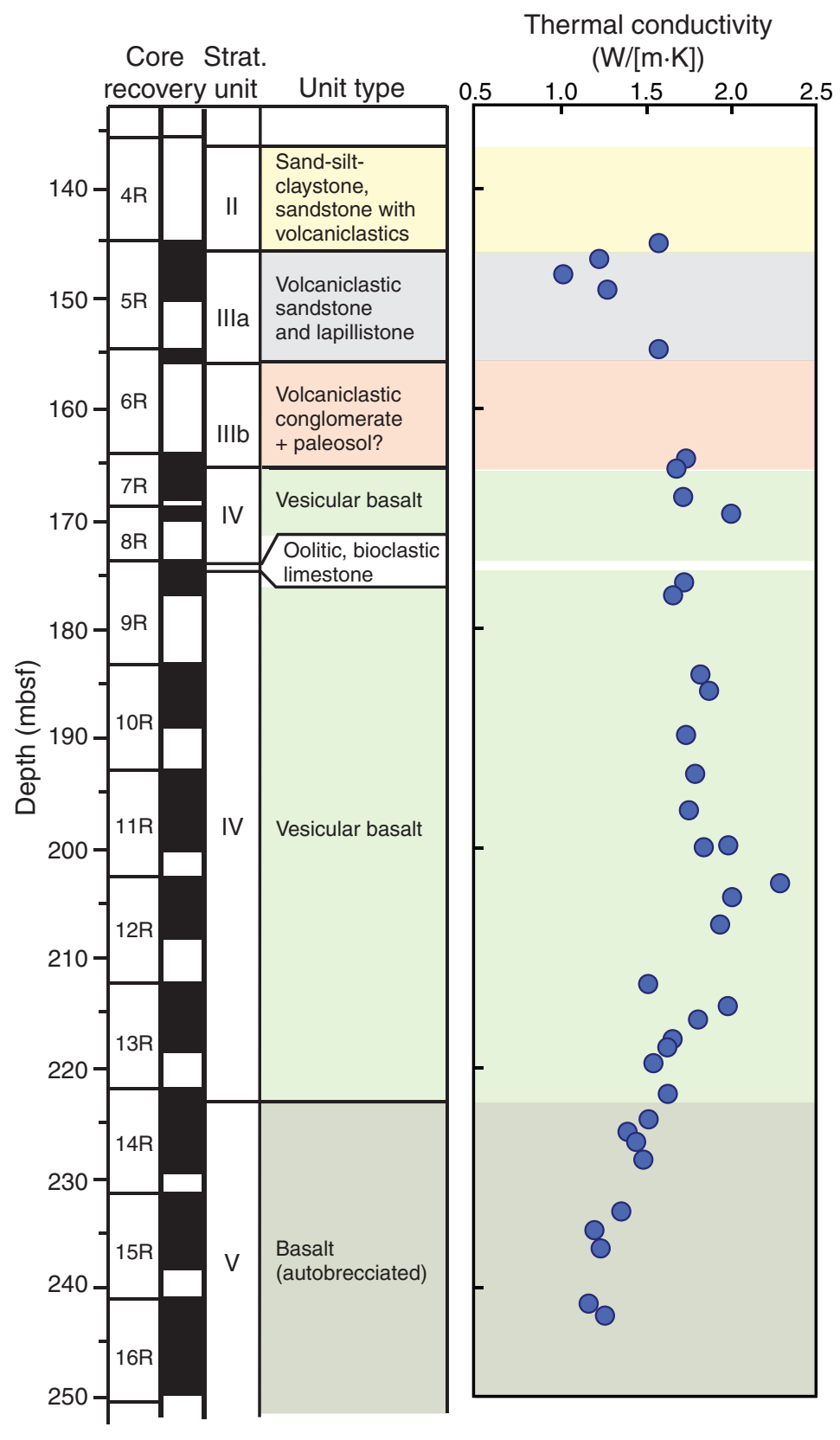


Figure F64. Example orthogonal vector plots of (A, B) alternating-field and (C, D) thermal demagnetization results, Hole U1349A. Open circles = inclinations, solid circles = declinations, NRM = natural remanent magnetization. Small plots show decay of magnetization with increasing alternating-field or thermal steps.

A Sample 324-U1349A-5R-1, 83-85 cm

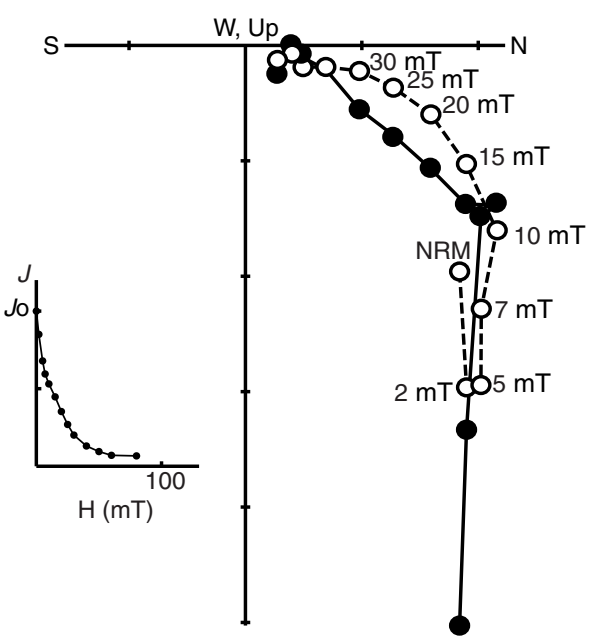

C

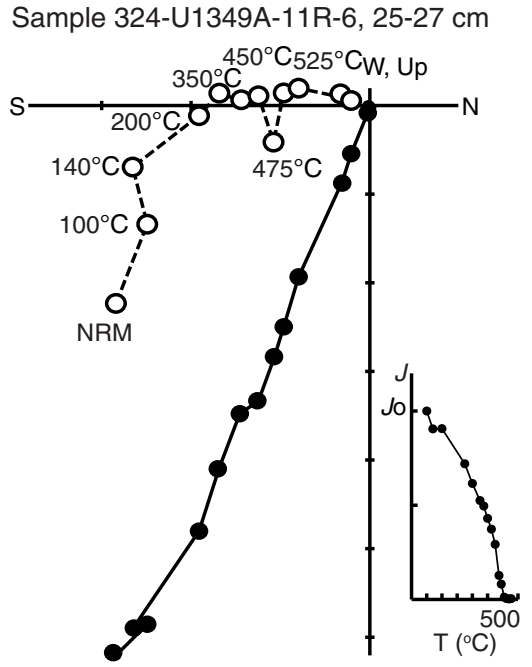

B Sample 324-U1349A-10R-4, 48-50 cm

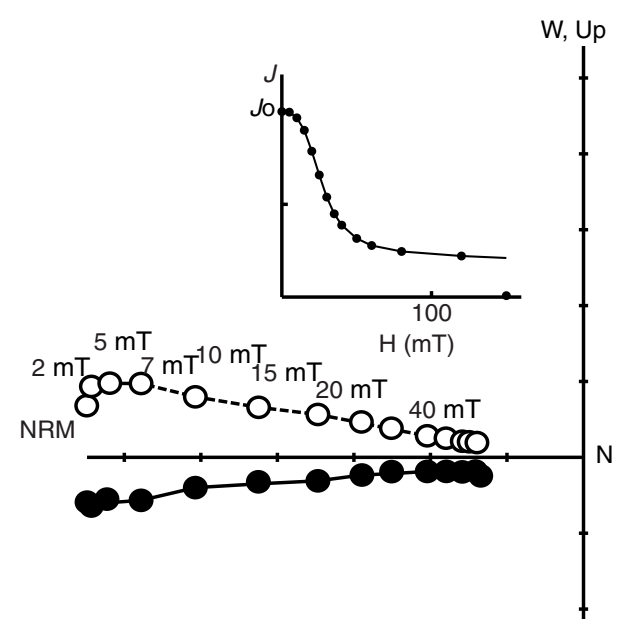

D Sample 324-U1349A-14R-2, 79-81 cm

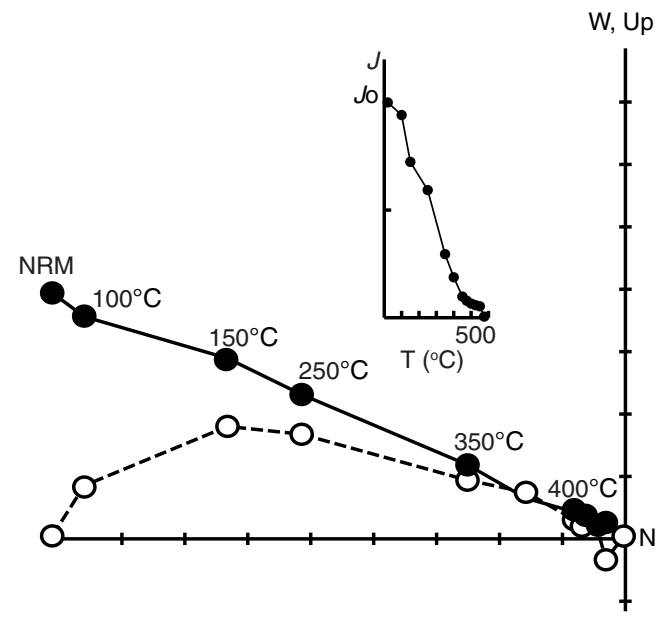


Figure F65. Demagnetization results for volcaniclastic and basalt samples vs. depth, Hole U1349A. AF demag = alternating-field demagnetization, $\mathrm{TH}$ demag = thermal demagnetization.

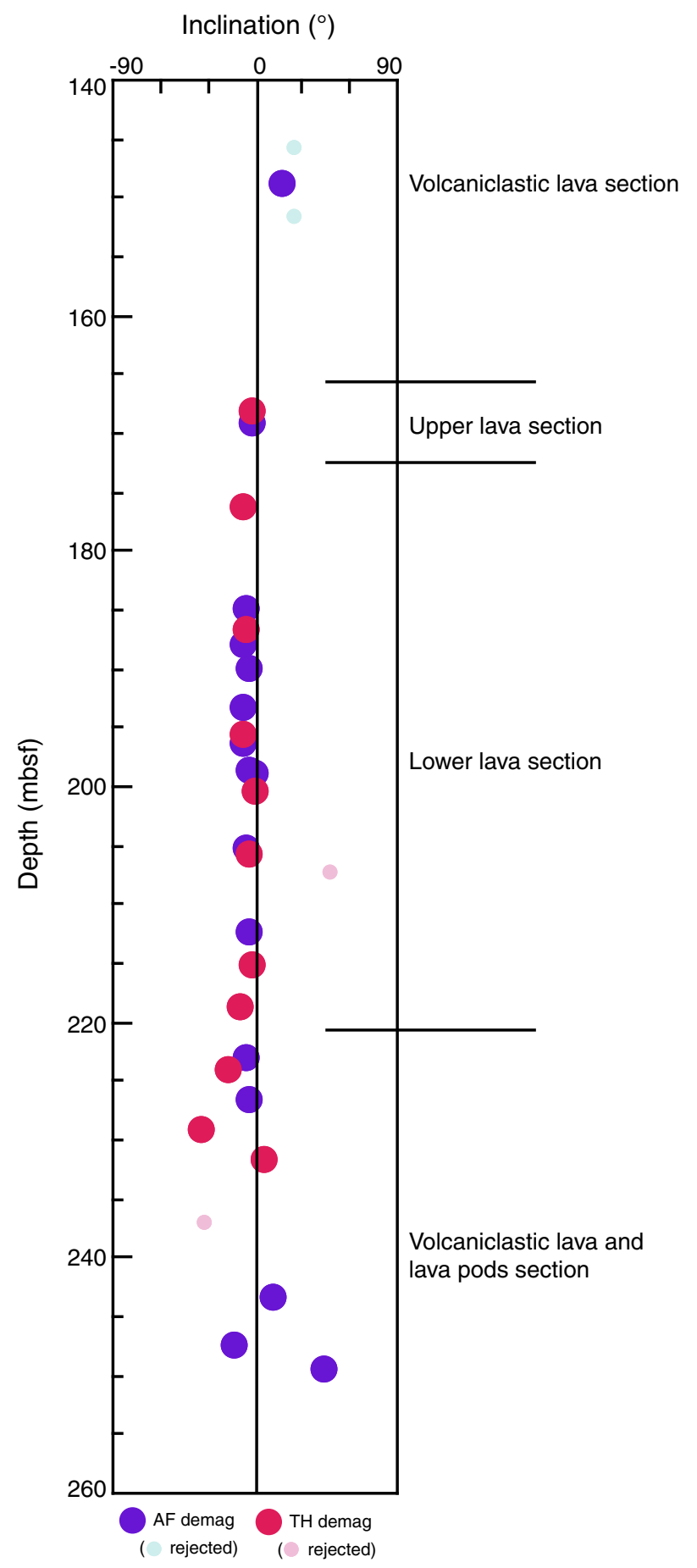


Figure F66. Downhole caliper, electrical resistivity, and gamma ray logs, Hole U1349A. LCAL $=$ caliper, IDPH = deep induction phasor-processed resistivity, IMPH = medium induction phasor-processed resistivity, SFLU = spherically focused resistivity, HSGR = gamma ray log, HCGR = computed gamma radiation.

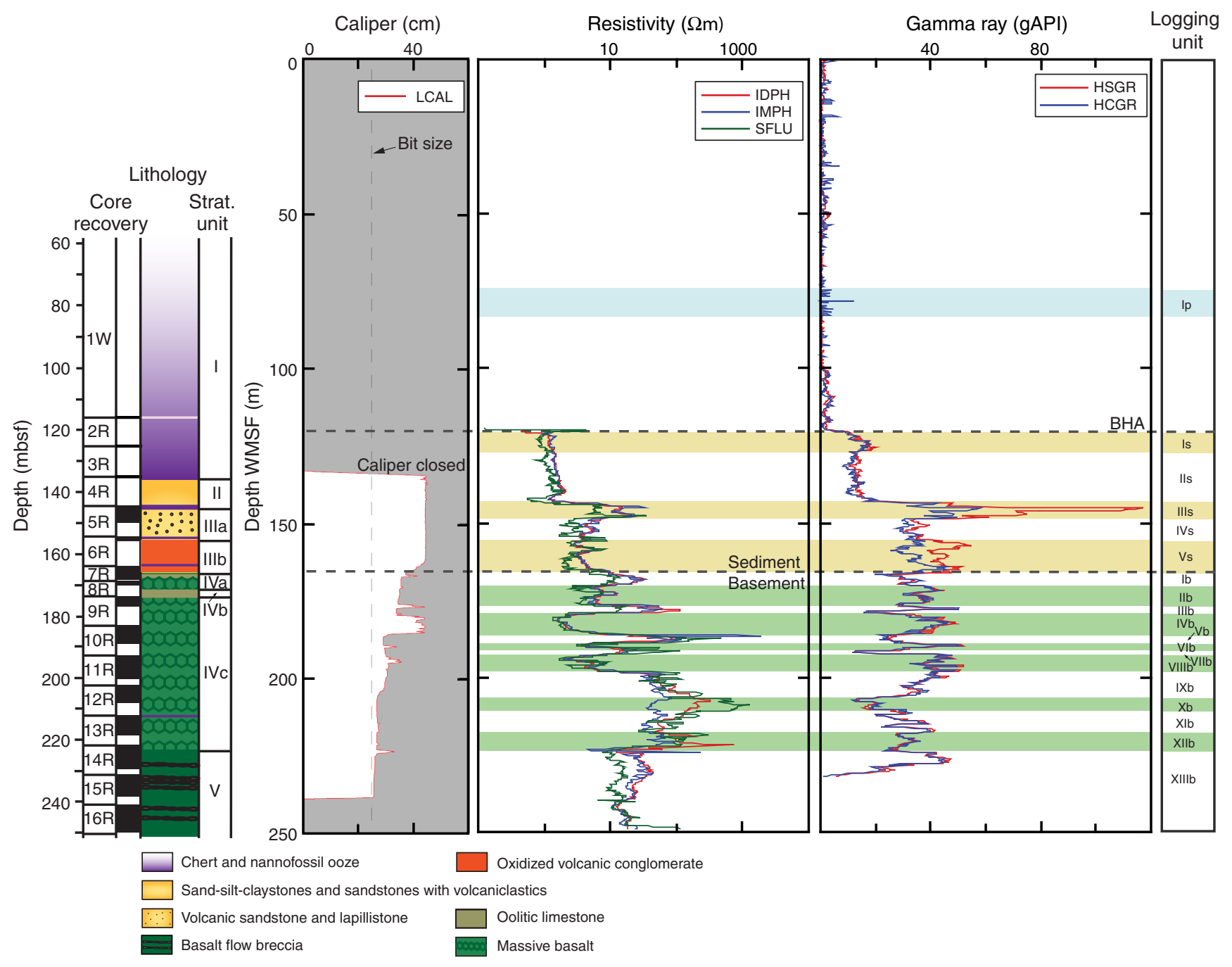


Figure F67. Downhole spectral gamma ray logs of uranium, thorium, and potassium, Hole U1349A. BHA = bottom-hole assembly.

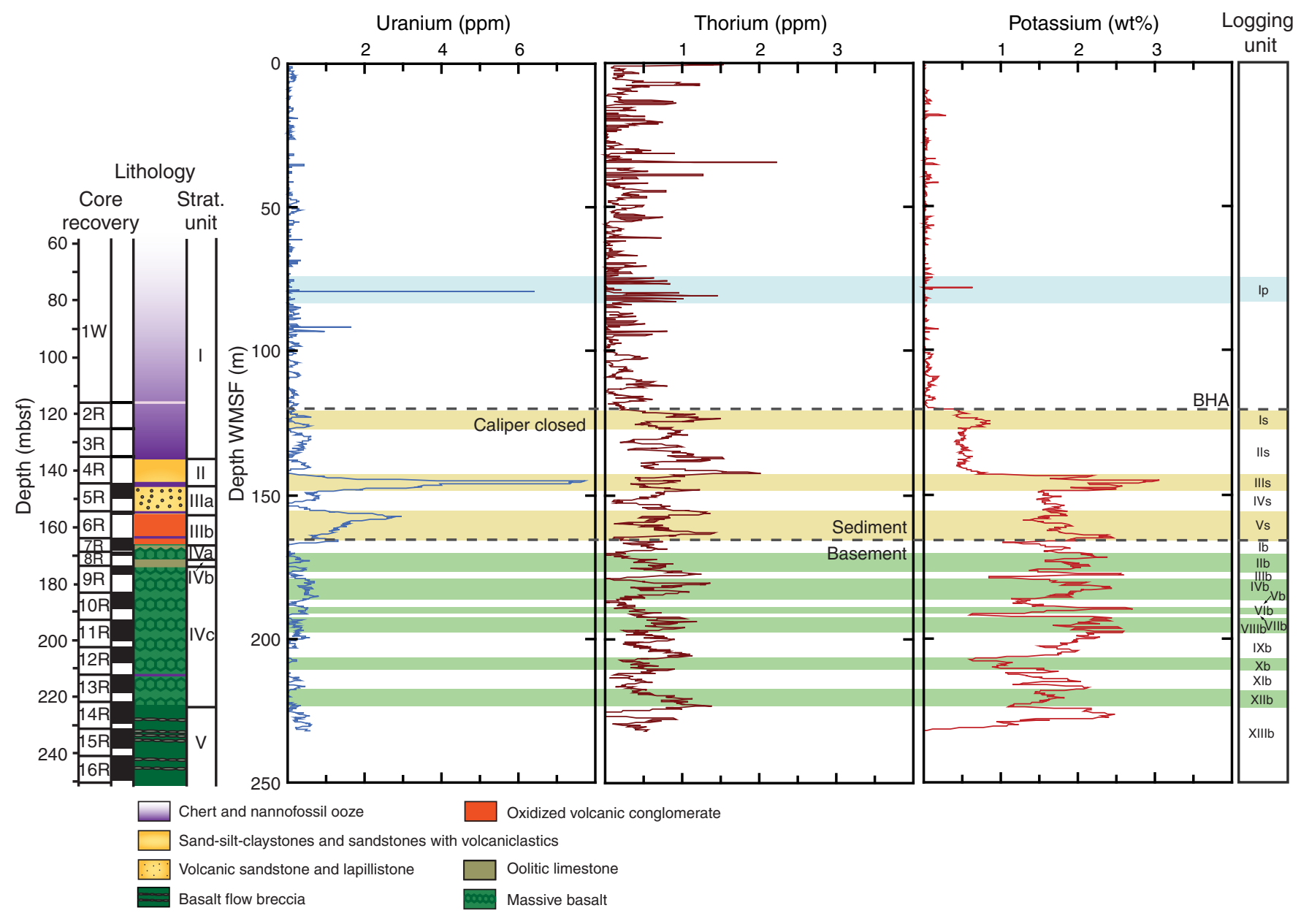


Figure F68. Downhole density and gamma ray logs, Hole U1349A. Solid circles = physical property measurements made on core samples. RHL = long-spaced bulk density, MAD = moisture and density, HSGR = gamma ray $\log , \mathrm{HCGR}=$ computed gamma radiation, NGR = natural gamma radiation, $\mathrm{BHA}=$ bottom-hole assembly.

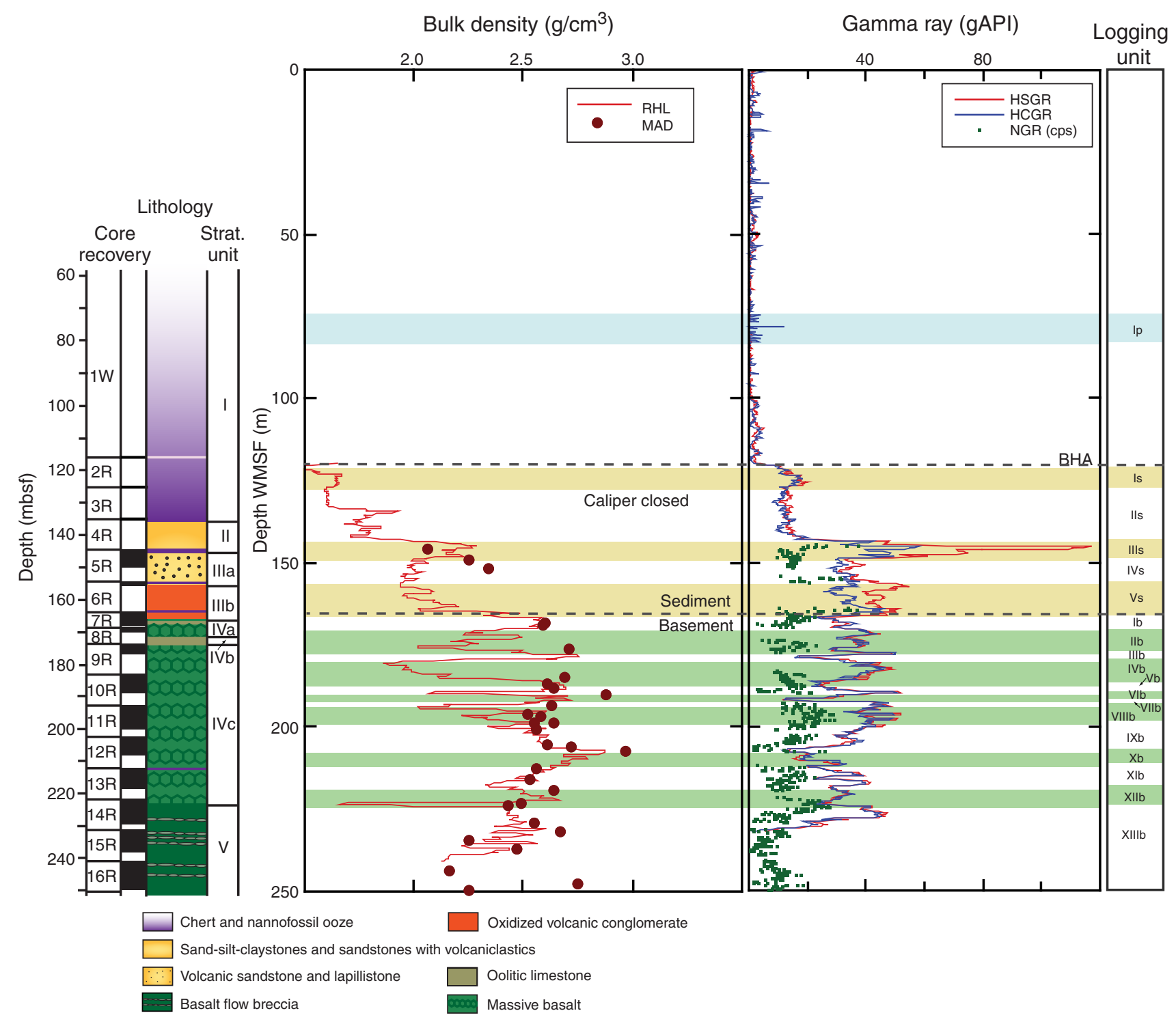


Figure F69. Downhole hole deviation, magnetic inclination, total magnetic field moment, and magnetic intensity, Hole U1349A. BHA = bottom-hole assembly. $\mathrm{F}_{x}, \mathrm{~F}_{y}, \mathrm{~F}_{z}=x-, y$-, and $z$-axis measurements. FINC = magnetic field inclination, FNOR = magnetic field total moment.

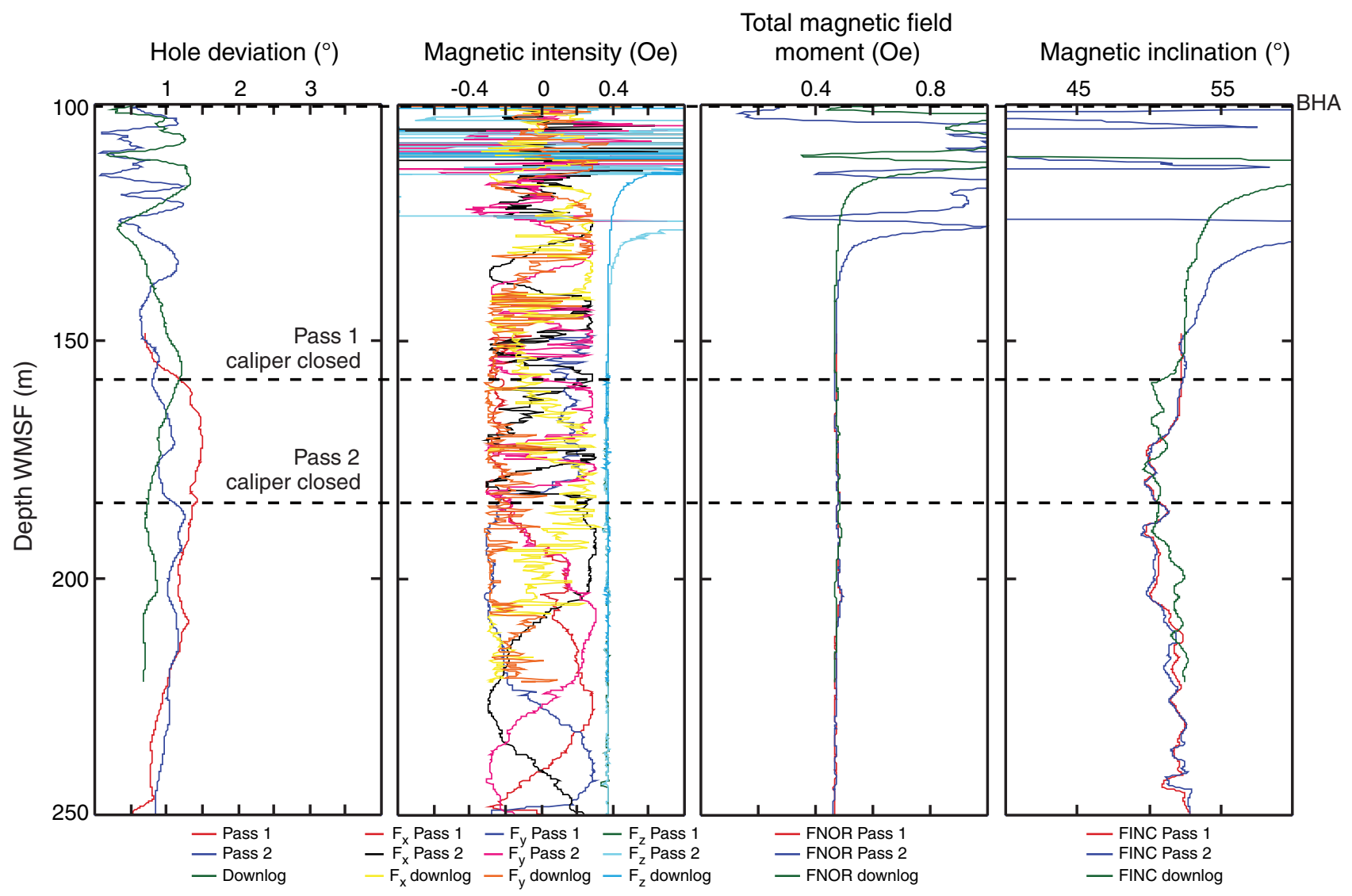


Figure F70. Formation MicroScanner images of subhorizontal layering and fractures in Hole U1349A. Core image provided to show similar structures in the core.

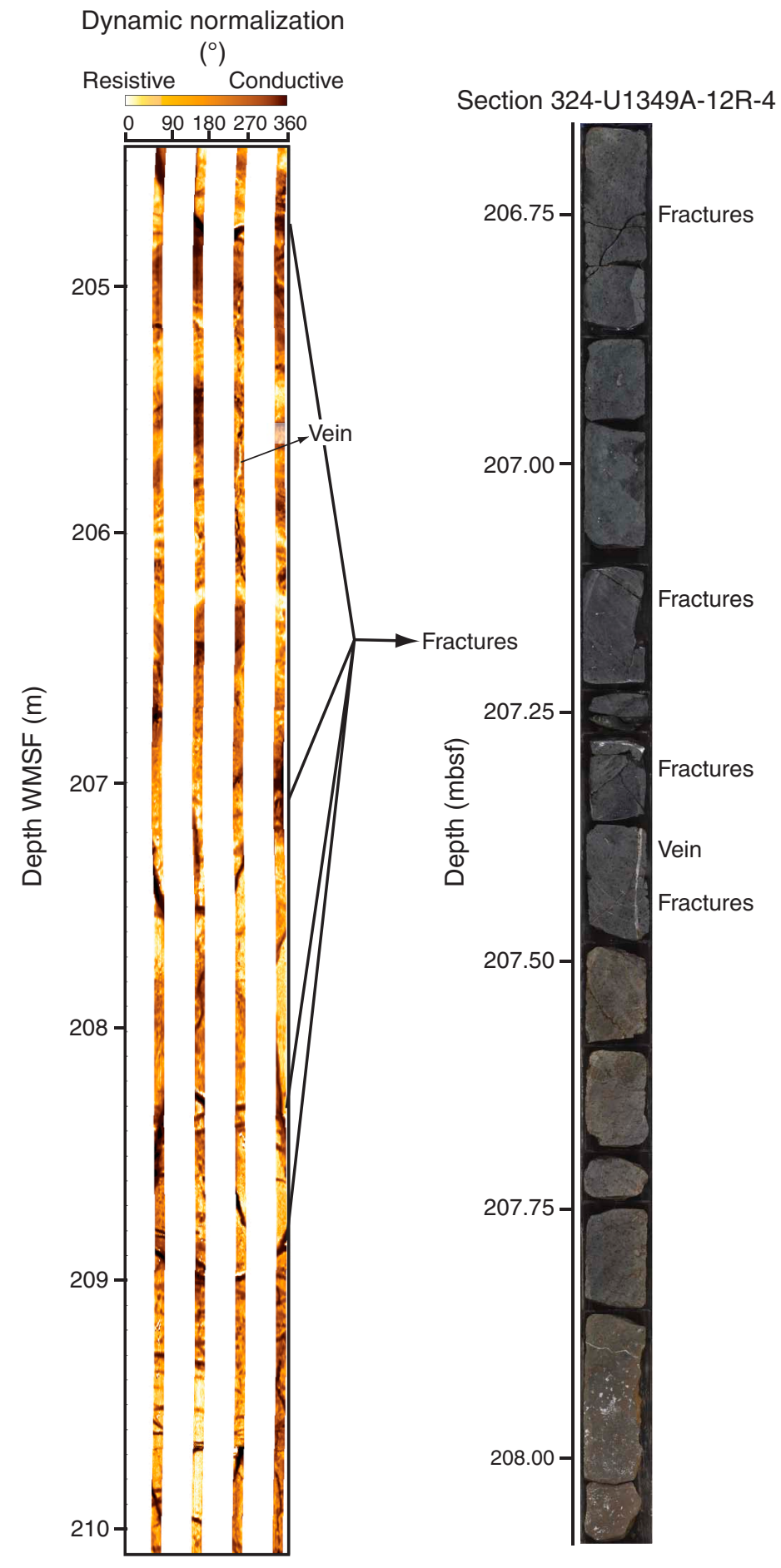


Figure F71. Formation MicroScanner (FMS) images of fractures and potential veins in the lower section of Hole U1349A. Core images provided to show similar structures in the core. Color levels on the core images were adjusted in order to accentuate the textures and contacts.

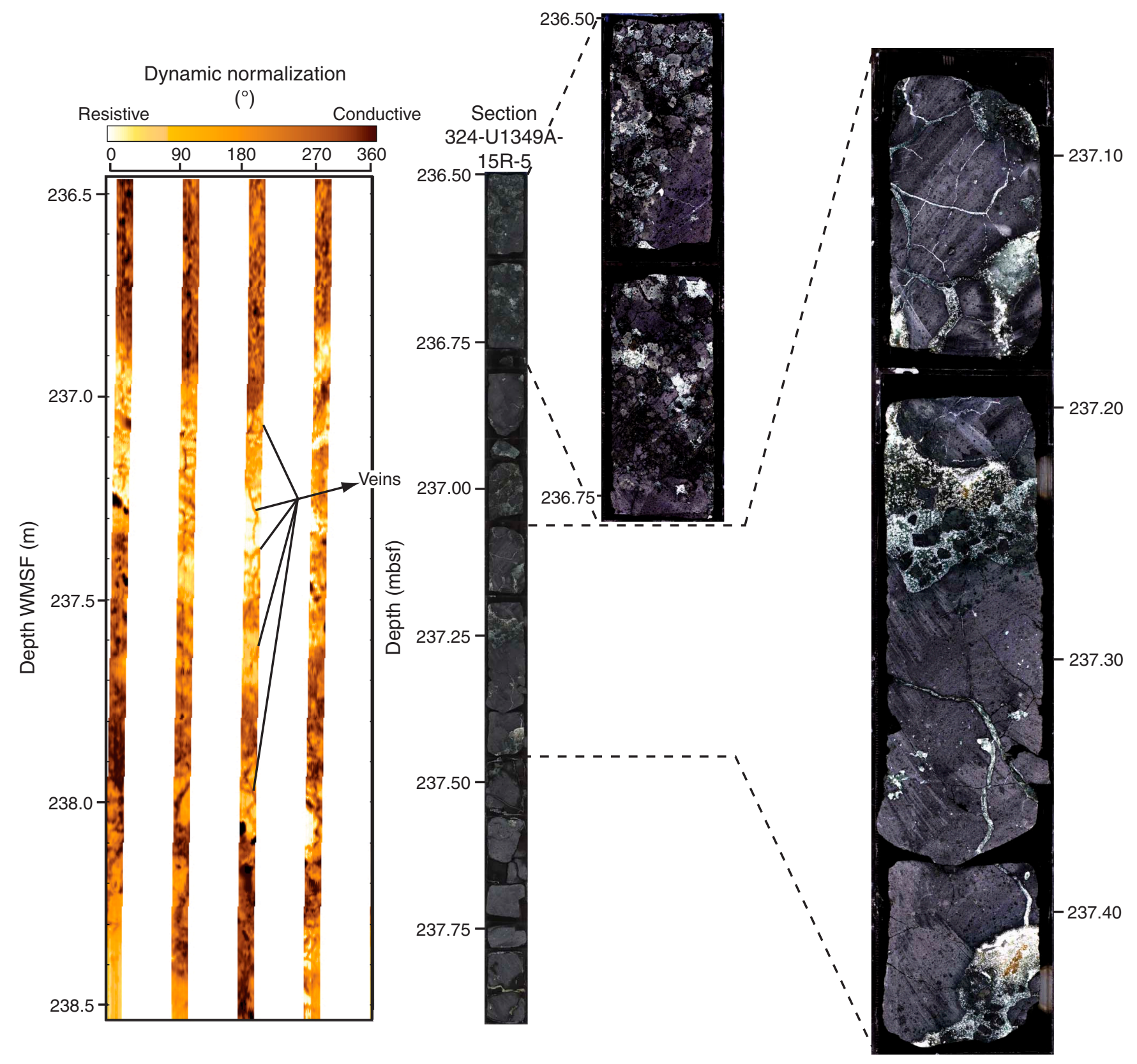


Table T1. Coring summary, Site U1349. (See table notes.)

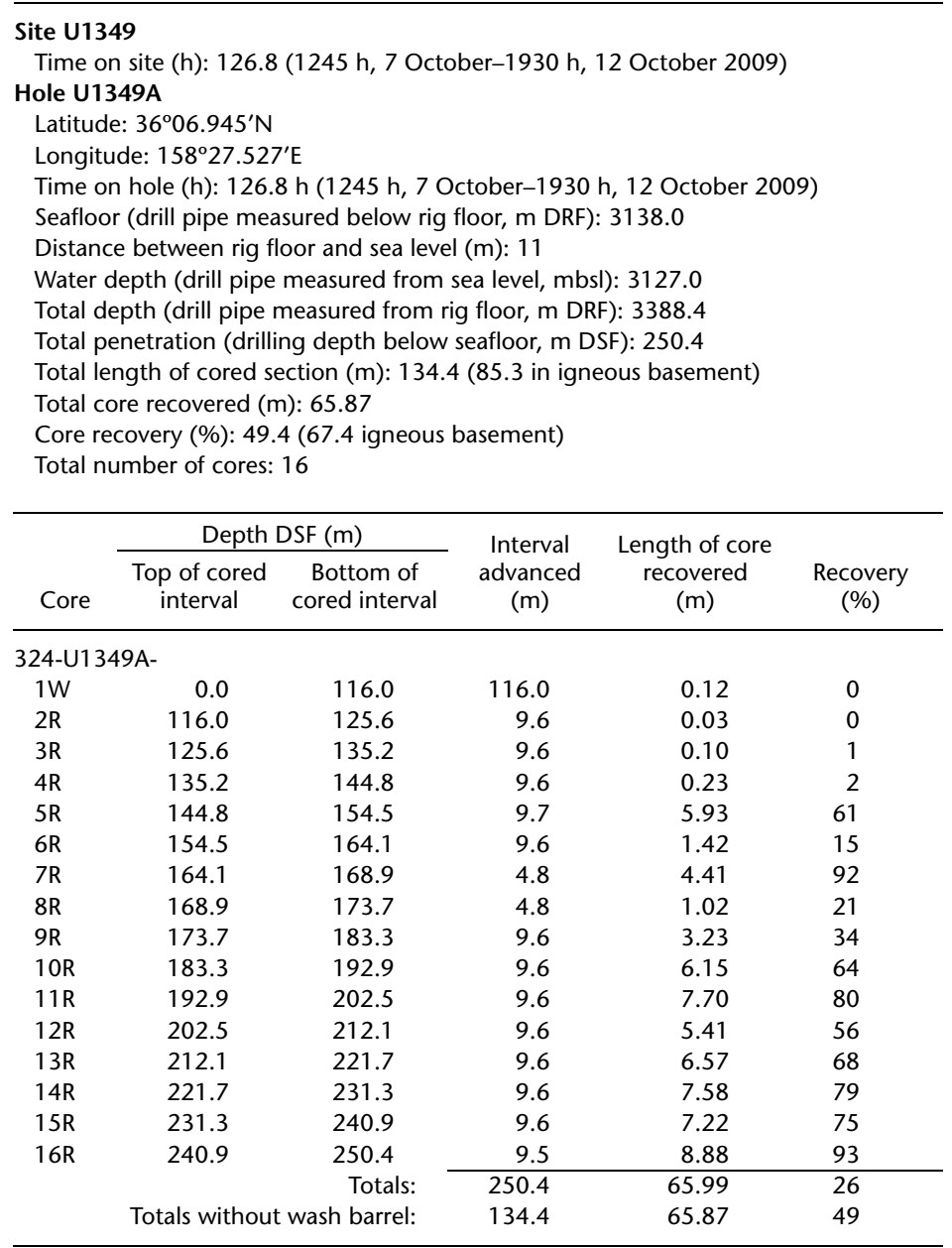

Notes: DRF $=$ drilling depth below rig floor, DSF $=$ drilling depth below seafloor. Local time $=\mathrm{UTC}+10 \mathrm{~h}$.

Table T2. Calcareous nannofossil age assignments, Site U1349. (See table notes.)

\begin{tabular}{|c|c|c|c|}
\hline $\begin{array}{l}\text { Core, section, } \\
\text { interval }(\mathrm{cm})\end{array}$ & $\begin{array}{l}\text { Age-diagnostic species } \\
\text { (Abundance) }\end{array}$ & Stratigraphic range (Zone) & Age estimation \\
\hline $\begin{array}{l}324-U 1349 A- \\
1 W-1,9-10\end{array}$ & $\begin{array}{l}\text { Zeugrhabdotus sp. }(\mathrm{R}) \\
\text { Watznaueria britannica }(\mathrm{R})\end{array}$ & $\begin{array}{l}\text { upper Kimmeridigian-Campanian } \\
\text { lower Bajocian-Cenomanian (NJ9-UC1) }\end{array}$ & Early to mid-Cretaceous \\
\hline $2 \mathrm{R}-1,0-1$ & $\begin{array}{l}\text { Reinhardites levis }(\mathrm{F}) \\
\text { Cretarhabdus striatus (R) } \\
\text { Diazmolithus lehmanii (R) }\end{array}$ & $\begin{array}{l}\text { upper Campanian-Maastrichtian (?-CC25/UC19) } \\
\text { Aptian-upper Cenomanian (?-UC4) } \\
\text { Cretaceous }\end{array}$ & Cretaceous \\
\hline $3 R-1,5-6$ & Rhagodiscus robustus (R) & Barremian-upper Albian (NC5-NC10a) & \\
\hline $4 \mathrm{R}-1,9-10$ & $\begin{array}{l}\text { Rotelappilius sp. (R) } \\
\text { Zeugrhabdotus sp. (R) }\end{array}$ & $\begin{array}{l}\text { Cretaceous } \\
\text { Cretaceous }\end{array}$ & Cretaceous \\
\hline
\end{tabular}

Notes: Abundance: $\mathrm{F}=$ frequent, $\mathrm{R}=$ rare. Zone ranges are only given for properly defined taxa. 
Table T3. Planktonic foraminifer preservation, abundance, and age assignments, Site U1349. (See table notes.)

\begin{tabular}{|c|c|c|c|c|c|c|c|c|c|c|c|c|c|c|c|c|c|}
\hline $\begin{array}{l}\text { Core, section, } \\
\text { interval }(\mathrm{cm})\end{array}$ & $\begin{array}{l}\text { Depth } \\
\text { (mbsf) }\end{array}$ & $\begin{array}{l}\text { Size } \\
\text { fraction } \\
(\mu \mathrm{m})\end{array}$ & 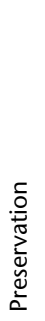 & 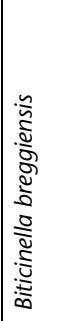 & 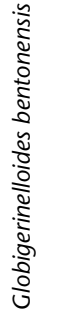 & 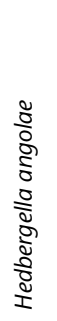 & 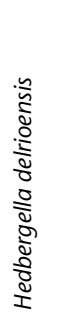 & 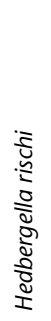 & 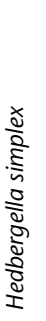 & 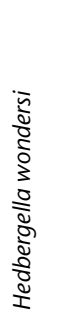 & 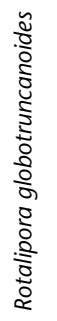 & 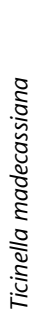 & 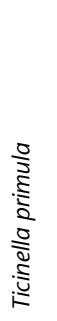 & 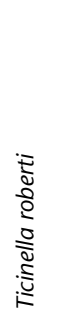 & 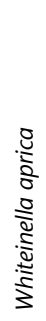 & Zone & Age \\
\hline $\begin{array}{c}324-U 1349 A- \\
1 \mathrm{~W}-1,5-9 \\
2 \mathrm{R}-1,1-2 \\
4 \mathrm{R}-1,9-10\end{array}$ & $\begin{array}{r}0.07 \\
116.02 \\
135.39\end{array}$ & $\begin{array}{l}>125 \\
>150 \\
>125\end{array}$ & $\begin{array}{l}P \\
G \\
G\end{array}$ & $\mathrm{R}$ & A & $\mathrm{T}$ & $\begin{array}{l}\mathrm{R} \\
\mathrm{R}\end{array}$ & C & $\mathrm{R}$ & A & $\mathrm{T}$ & $\begin{array}{l}A \\
F\end{array}$ & A & c & $\mathrm{R}$ & $\begin{array}{l}\text { (R. globotruncanoides) } \\
\text { T. primula } \\
\text { (T. primula) }\end{array}$ & $\begin{array}{l}\text { late Cenomanian } \\
\text { middle-late Albian transition } \\
\text { middle Albian }\end{array}$ \\
\hline
\end{tabular}

Notes: Preservation: $\mathrm{G}=$ good, $\mathrm{P}=$ poor. Abundance: $\mathrm{A}=$ abundant, $\mathrm{C}=$ common, $\mathrm{F}=$ few, $\mathrm{R}=$ rare, $\mathrm{T}=$ trace. See "Paleontology" in the "Methods" chapter for preservation and abundance descriptions. Parentheses indicate that the zone is indirectly defined by secondary marker or assemblage (see text).

Table T4. Benthic foraminifer preservation and abundance, Site U1349. (See table notes.)

\begin{tabular}{|c|c|c|c|c|c|c|c|c|c|c|c|c|c|c|c|c|c|c|c|c|c|c|}
\hline \multirow[b]{2}{*}{$\begin{array}{l}\text { Core, section, } \\
\text { interval }(\mathrm{cm})\end{array}$} & \multirow[b]{2}{*}{$\begin{array}{l}\text { Depth } \\
\text { (mbsf) }\end{array}$} & \multirow[b]{2}{*}{$\begin{array}{c}\text { Size } \\
\text { fraction } \\
(\mu \mathrm{m})\end{array}$} & \multirow[b]{2}{*}{ 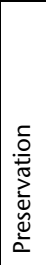 } & \multicolumn{4}{|c|}{ Agglutinated } & \multicolumn{15}{|c|}{ Calcareous } \\
\hline & & & & 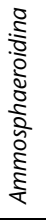 & $\begin{array}{l}\frac{0}{1} \\
\frac{1}{3} \\
\frac{5}{3} \\
ن\end{array}$ & 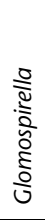 & 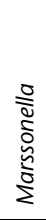 & 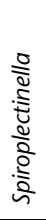 & 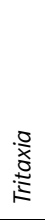 & 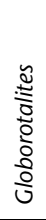 & $\begin{array}{l}\frac{\tilde{y}}{0} \\
\frac{0}{0} \\
\frac{0}{0} \\
\frac{0}{0}\end{array}$ & 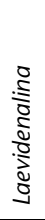 & 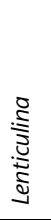 & $\begin{array}{l}\text { : } \\
\text { o } \\
\text { o } \\
\overline{5} \\
0\end{array}$ & $\begin{array}{l}\frac{D}{5} \\
\frac{0}{3} \\
\frac{d}{a} \\
\frac{D}{a}\end{array}$ & 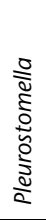 & 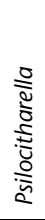 & 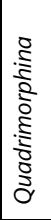 & 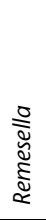 & 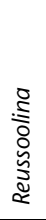 & 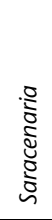 & 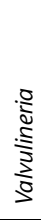 \\
\hline $\begin{array}{c}324-U 1349 A- \\
1 W-1,5-9\end{array}$ & 0.07 & $>125$ & M & & & & & & & & $\mathrm{T}$ & & & $\mathrm{T}$ & & & & & & & & \\
\hline $2 \mathrm{R}-1,1-2$ & 116.02 & $>150$ & G & $\mathrm{R}$ & A & $\mathrm{T}$ & $\mathrm{T}$ & $\mathrm{F}$ & $\mathrm{T}$ & $\mathrm{T}$ & A & $\mathrm{R}$ & $\mathrm{F}$ & A & $\mathrm{T}$ & $\mathrm{T}$ & $\mathrm{T}$ & $\mathrm{T}$ & $\mathrm{T}$ & $\mathrm{R}$ & $\mathrm{T}$ & $\mathrm{R}$ \\
\hline $4 \mathrm{R}-1,9-10$ & 135.39 & $>125$ & B & & & & & & & & & & & & & & & & & & & \\
\hline
\end{tabular}

Notes: Preservation: $\mathrm{G}=$ good, $\mathrm{M}=$ moderate, $\mathrm{B}=$ barren. Abundance: $\mathrm{A}=$ abundant, $\mathrm{F}=\mathrm{few}, \mathrm{R}=$ rare, $\mathrm{T}=$ trace. See "Paleontology" in the "Methods" chapter for preservation and abundance descriptions. 
Table T5. Original microphenocryst and/or phenocryst abundances, Site U1349. (See table notes.)

\begin{tabular}{|c|c|c|c|c|c|c|c|}
\hline \multirow{3}{*}{$\begin{array}{l}\text { Thin } \\
\text { section } \\
\text { number }\end{array}$} & \multirow{3}{*}{$\begin{array}{l}\text { Core, section, } \\
\text { interval }(\mathrm{cm})\end{array}$} & \multirow{3}{*}{$\begin{array}{l}\text { Unit in } \\
\text { VCD }\end{array}$} & \multirow{3}{*}{$\begin{array}{l}\text { Recovered } \\
\text { thickness } \\
\text { (m) }\end{array}$} & \multicolumn{3}{|c|}{ Original modal abundance } & \multirow{3}{*}{$\begin{array}{c}\text { Stratigraphic } \\
\text { unit }\end{array}$} \\
\hline & & & & \multicolumn{2}{|c|}{ Olivine } & Pyroxene & \\
\hline & & & & $R \quad P$ & A & $\begin{array}{lll}R & P & A\end{array}$ & \\
\hline & 324-U1349A- & & & & & & \\
\hline 205 & 7R-1, 65-67 & 3 & 0.9 & & & & \\
\hline 206 & 7R-1, 112-115 & 4 & 0.58 & & & & \\
\hline 207 & 7R-2, 29-33 & 5 & 0.55 & & & & \\
\hline 208 & 7R-2, 78-81 & 6 & 0.26 & & & & \\
\hline 209 & $7 R-3,39-43$ & 8 & 0.93 & & & & \\
\hline 210 & $7 R-3,111-113$ & 9 & 0.43 & & & & \\
\hline 211 & $7 R-4,32-35$ & 10 & 0.76 & & & & \\
\hline 214 & $9 R-1,24-26$ & 14 & 0.31 & & & & \\
\hline 215 & $9 \mathrm{R}-1,36-40$ & 14 & 0.31 & & & & \\
\hline 216 & $9 \mathrm{R}-1,127-132$ & 15 & 1.25 & & & & \\
\hline 217 & $9 \mathrm{R}-2,96-98$ & 16 & 2.21 & & & & \\
\hline 218 & $9 \mathrm{R}-3,6-9$ & 16 & 2.21 & & & & \\
\hline 219 & $10 \mathrm{R}-2,10-12$ & 17 & 4.22 & & & & \\
\hline 224 & $10 \mathrm{R}-2,44-49$ & 20 & 1.58 & & & & \\
\hline 220 & 10R-2, 85-91 & 17 & 4.22 & & & & \\
\hline 212 & 10R-2, 106-109 & 17 & 4.22 & & & & \\
\hline 221 & 10R-3, 43-48 & 17 & 4.22 & & & & \\
\hline 222 & 10R-3, 97-99 & 17 & 4.22 & & & & \\
\hline 223 & $10 \mathrm{R}-4,44-45$ & 18 & 0.76 & & & & \\
\hline 225 & 10R-5, 2-4 & 19 & 1.75 & & & & IV \\
\hline 226 & 11R-1, 30-32 & 20 & 1.58 & & & & \\
\hline 227 & $11 \mathrm{R}-1,124-128$ & 20 & 1.58 & & & & \\
\hline 228 & $11 \mathrm{R}-4,3-6$ & 22 & 5.94 & & & & \\
\hline 229 & $11 \mathrm{R}-4,88-93$ & 22 & 5.94 & & & & \\
\hline 230 & $11 \mathrm{R}-5,11-14$ & 22 & 5.94 & & & & \\
\hline 231 & $11 \mathrm{R}-5,75-77$ & 22 & 5.94 & & & & \\
\hline 232 & $11 \mathrm{R}-6,17-23$ & 22 & 5.94 & & & & \\
\hline 233 & $11 R-6,64-66$ & 22 & 5.94 & & & & \\
\hline 234 & $12 \mathrm{R}-2,111-113$ & 24 & 4 & & & & \\
\hline 235 & 12R-3, 32-34 & 24 & 4 & & & & \\
\hline 236 & $12 \mathrm{R}-3,122-123$ & 24 & 4 & & & & \\
\hline 237 & $12 \mathrm{R}-4,112-116$ & 24 & 4 & & & & \\
\hline 238 & 13R-1, 29-32 & 27 & 1 & & & & \\
\hline 239 & 13R-2, 9-12 & 27 & 1 & & & & \\
\hline 240 & $13 R-2,107-110$ & 28 & 1 & & & & \\
\hline 241 & 13R-3, 69-72 & 29 & 1 & & & & \\
\hline 242 & $13 R-3,144-146$ & 29 & 1 & & & & \\
\hline 243 & $13 R-4,123-126$ & 31 & 3 & & & & \\
\hline 244 & 13R-6, 9-12 & 31 & 3 & & & & \\
\hline 245 & 14R-1, 38-42 & 32 & 25 & & & & \\
\hline 251 & 14R-1, 124-127 & 32 & 25 & & & & \\
\hline 246 & $14 R-4,50-56$ & 32 & 25 & & & & \\
\hline 247 & 14R-4, 97-98 & 32 & 25 & & & & \\
\hline 248 & $14 \mathrm{R}-5,25-31$ & 32 & 25 & & & & \\
\hline 249 & $14 \mathrm{R}-5,53-54$ & 32 & 25 & & & & \\
\hline 250 & $14 \mathrm{R}-6,64-67$ & 32 & 25 & & & & \\
\hline 252 & $15 R-3,79-85$ & 32 & 8 & & & & \\
\hline 253 & 15R-3, 115-118 & 32 & 8 & & & & \\
\hline 254 & $15 R-4,104-110$ & 32 & 8 & & & & V \\
\hline 255 & 15R-5, 6-12 & 32 & 8 & & & & \\
\hline 256 & $15 R-5,15-20$ & 32 & 8 & & & & \\
\hline 257 & $15 R-6,42-44$ & 32 & 8 & & & & \\
\hline 258 & 16R-2, 7-14 & 32 & 6 & & & & \\
\hline 259 & $16 R-2,44-50$ & 32 & 6 & & & & \\
\hline 260 & 16R-6, 7-12 & 32 & 1 & & & & \\
\hline 261 & $16 R-6,56-61$ & 32 & 1 & & & & \\
\hline 262 & $16 \mathrm{R}-6,77-83$ & 32 & 2 & & & & \\
\hline 263 & 16R-7, 64-71 & 32 & 2 & & & & \\
\hline
\end{tabular}

Notes: $\mathrm{VCD}=$ visual core description. $\mathrm{R}=$ rare $(<1 \%), \mathrm{P}=$ present $(1 \%-5 \%), \mathrm{A}=$ abundant $(>5 \%)$. 
Table T6. Whole-rock major and trace element compositions, Hole U1349A. (See table notes.)

\begin{tabular}{|c|c|c|c|c|c|c|c|c|c|c|c|c|c|}
\hline \multirow{3}{*}{$\begin{array}{r}\text { Stratigraphic unit: } \\
\text { Core: }\end{array}$} & \multicolumn{13}{|c|}{ 324-U1349A- } \\
\hline & \multicolumn{8}{|c|}{ IV } & \multicolumn{5}{|c|}{ V } \\
\hline & $7 R$ & $9 \mathrm{R}$ & $10 \mathrm{R}$ & $10 R$ & $11 R^{*}$ & $11 R^{\dagger}$ & $12 \mathrm{R}$ & $13 R$ & $14 \mathrm{R}$ & $14 \mathrm{R}$ & $14 \mathrm{R}$ & $15 R$ & $16 \mathrm{R}$ \\
\hline Section: & 3 & 2 & 2 & 4 & 5 & 5 & 3 & 4 & 1 & 4 & 6 & 6 & 6 \\
\hline Piece: & $11 \mathrm{~A}$ & 11 & 7 & $7 B$ & $1 \mathrm{~A}$ & $1 \mathrm{~A}$ & 15 & 22 & 9 & $8 B$ & $4 \mathrm{~A}$ & 4 & 1 \\
\hline Interval $(\mathrm{cm})$ : & $111-113$ & $93-95$ & $108-110$ & $42-44$ & $12-15$ & $12-15$ & $119-122$ & $127-128$ & $38-42$ & $96-98$ & $64-66$ & $43-45$ & $0-2$ \\
\hline Top depth (mbsf): & 168.05 & 176.02 & 185.77 & 187.80 & 198.58 & 198.58 & 206.56 & 217.68 & 222.08 & 226.36 & 228.80 & 238.30 & 247.76 \\
\hline \multicolumn{14}{|c|}{ Major element oxide (wt\%): } \\
\hline $\mathrm{SiO}_{2}$ & 40.01 & 46.17 & 39.09 & 43.40 & 40.47 & 15.88 & 46.51 & 46.98 & 43.01 & 47.85 & 48.59 & 48.77 & 47.70 \\
\hline $\mathrm{TiO}_{2}$ & 1.19 & 1.18 & 1.01 & 1.02 & 1.06 & 0.40 & 0.93 & 0.86 & 0.93 & 0.94 & 0.94 & 1.04 & 0.94 \\
\hline $\mathrm{Al}_{2} \mathrm{O}_{3}$ & 17.04 & 16.49 & 17.06 & 17.00 & 17.11 & 7.64 & 16.47 & 15.50 & 16.38 & 16.69 & 16.63 & 18.14 & 16.37 \\
\hline $\mathrm{Fe}_{2} \mathrm{O}_{3}^{\top}$ & 12.48 & 11.99 & 12.91 & 12.33 & 14.65 & 6.41 & 10.13 & 11.94 & 14.37 & 11.34 & 11.83 & 10.24 & 11.68 \\
\hline $\mathrm{MnO}$ & 0.13 & 0.12 & 0.12 & 0.14 & 0.13 & 0.23 & 0.16 & 0.16 & 0.16 & 0.22 & 0.23 & 0.14 & 0.19 \\
\hline $\mathrm{MgO}$ & 3.30 & 7.94 & 4.41 & 4.36 & 5.33 & 2.83 & 8.67 & 10.89 & 6.00 & 15.62 & 12.01 & 10.67 & 8.76 \\
\hline $\mathrm{CaO}$ & 23.26 & 12.52 & 20.66 & 19.42 & 14.89 & 68.16 & 13.30 & 8.36 & 14.86 & 4.10 & 9.65 & 9.06 & 12.24 \\
\hline $\mathrm{Na}_{2} \mathrm{O}$ & 1.78 & 2.01 & 1.80 & 2.01 & 0.67 & 0.02 & 1.70 & 1.62 & 1.70 & 2.14 & 2.06 & 2.33 & 2.14 \\
\hline $\mathrm{K}_{2} \mathrm{O}$ & 2.77 & 1.38 & 1.83 & 1.74 & 5.90 & 1.68 & 2.28 & 1.92 & 2.71 & 0.80 & BD & 0.02 & BD \\
\hline $\mathrm{P}_{2} \mathrm{O}_{5}$ & 0.13 & 0.11 & 0.16 & 0.09 & 0.66 & 0.08 & 0.10 & 0.04 & 0.13 & 0.01 & BD & BD & 0.08 \\
\hline Totals: & 102.10 & 99.90 & 99.05 & 101.51 & 100.86 & 103.32 & 100.26 & 98.28 & 100.24 & 99.71 & 101.95 & 100.40 & 100.09 \\
\hline LOI & 15.65 & 4.63 & 10.57 & 10.03 & 14.47 & 34.76 & 6.51 & 5.50 & 10.65 & 2.60 & 4.99 & 3.21 & 2.37 \\
\hline \multicolumn{14}{|c|}{ Major element oxide (wt\%) normalized to 100 wt\%: } \\
\hline $\mathrm{SiO}_{2}$ & 39.19 & 46.22 & 39.47 & 42.75 & 40.12 & 15.37 & 46.39 & 47.81 & 42.90 & 47.99 & 47.66 & 48.58 & 47.66 \\
\hline $\mathrm{TiO}_{2}$ & 1.16 & 1.18 & 1.02 & 1.00 & 1.06 & 0.39 & 0.93 & 0.88 & 0.93 & 0.94 & 0.92 & 1.03 & 0.94 \\
\hline $\mathrm{Al}_{2} \mathrm{O}_{3}$ & 16.69 & 16.51 & 17.22 & 16.75 & 16.96 & 7.39 & 16.42 & 15.78 & 16.34 & 16.74 & 16.31 & 18.06 & 16.35 \\
\hline $\mathrm{Fe}_{2} \mathrm{O}_{3}^{\top}$ & 12.23 & 12.01 & 13.04 & 12.14 & 14.52 & 6.20 & 10.10 & 12.15 & 14.34 & 11.38 & 11.60 & 10.20 & 11.67 \\
\hline $\mathrm{MnO}$ & 0.13 & 0.12 & 0.12 & 0.14 & 0.13 & 0.22 & 0.16 & 0.16 & 0.16 & 0.22 & 0.23 & 0.14 & 0.19 \\
\hline $\mathrm{MgO}$ & 3.23 & 7.94 & 4.45 & 4.29 & 5.28 & 2.74 & 8.64 & 11.08 & 5.99 & 15.67 & 11.78 & 10.63 & 8.75 \\
\hline $\mathrm{CaO}$ & 22.79 & 12.53 & 20.86 & 19.13 & 14.77 & 65.97 & 13.27 & 8.51 & 14.82 & 4.11 & 9.46 & 9.02 & 12.23 \\
\hline $\mathrm{Na}_{2} \mathrm{O}$ & 1.74 & 2.01 & 1.82 & 1.98 & 0.66 & 0.02 & 1.70 & 1.65 & 1.70 & 2.15 & 2.02 & 2.32 & 2.14 \\
\hline $\mathrm{K}_{2} \mathrm{O}$ & 2.71 & 1.38 & 1.84 & 1.71 & 5.85 & 1.62 & 2.27 & 1.95 & 2.70 & 0.81 & $\mathrm{BD}$ & 0.02 & $\mathrm{BD}$ \\
\hline $\mathrm{P}_{2} \mathrm{O}_{5}$ & 0.13 & 0.11 & 0.16 & 0.09 & 0.65 & 0.08 & 0.10 & 0.05 & 0.13 & 0.01 & $\mathrm{BD}$ & $\mathrm{BD}$ & 0.08 \\
\hline Totals: & 100.00 & 100.00 & 100.00 & 100.00 & 100.00 & 100.00 & 100.00 & 100.00 & 100.00 & 100.00 & 100.00 & 100.00 & 100.00 \\
\hline $\mathrm{Mg} \#$ & 38.1 & 60.6 & 44.3 & 45.1 & 45.8 & 50.7 & 66.6 & 68.0 & 49.3 & 76.2 & 70.3 & 70.8 & 63.6 \\
\hline \multicolumn{14}{|l|}{ Trace element (ppm): } \\
\hline $\mathrm{Ba}$ & 63 & 42 & 47 & 50 & 93 & 36 & 76 & 37 & 43 & 16 & 14 & 14 & 22 \\
\hline $\mathrm{Sr}$ & 148 & 94 & 145 & 114 & 258 & 232 & 85 & 50 & 96 & 62 & 72 & 82 & 72 \\
\hline $\mathrm{Zr}$ & 51 & 53 & 45 & 45 & 55 & 16 & 45 & 51 & 50 & 44 & 44 & 45 & 54 \\
\hline $\mathrm{Y}$ & 30 & 26 & 31 & 29 & 35 & 17 & 24 & 22 & 24 & 9 & 19 & 16 & 21 \\
\hline V & 324 & 345 & 317 & 296 & 296 & 98 & 297 & 282 & 265 & 310 & 307 & 338 & 310 \\
\hline Sc & 50 & 51 & 53 & 50 & 44 & 21 & 48 & 47 & 49 & 50 & 51 & 56 & 50 \\
\hline $\mathrm{Cu}$ & 97 & 151 & 144 & 143 & 104 & 45 & 174 & 121 & 94 & 132 & 139 & 152 & 133 \\
\hline $\mathrm{Zn}$ & 75 & 104 & 58 & 88 & 165 & 35 & 151 & 67 & 184 & 84 & 80 & 74 & 77 \\
\hline Co & 33 & 43 & 40 & 57 & 82 & 27 & 128 & 61 & 49 & 81 & 70 & 72 & 78 \\
\hline $\mathrm{Cr}$ & 355 & 338 & 541 & 427 & 607 & 180 & 510 & 498 & 566 & 536 & 548 & 560 & 513 \\
\hline $\mathrm{Ni}$ & 124 & 161 & 158 & 127 & 250 & 103 & 295 & 303 & 211 & 350 & 286 & 278 & 263 \\
\hline
\end{tabular}

Notes: ${ }^{*}=$ reddish (oxidized) split, $\dagger=$ highly vesicular split. All analyses were conducted on samples ignited to $975^{\circ} \mathrm{C}$. Fe $\mathrm{O}_{3}{ }^{\top}=$ total iron expressed as $\mathrm{Fe}_{2} \mathrm{O}_{3}$. $\mathrm{LOI}=$ weight loss on ignition. $\mathrm{Mg} \#=100 \times\left(\mathrm{Mg}^{2+} /\left[\mathrm{Mg}^{2+}+\mathrm{Fe}^{2+}\right]\right)$, assuming that $\mathrm{Fe}_{2} \mathrm{O}_{3} / \mathrm{FeO}=0.15$. $\mathrm{BD}=$ below detection. 
Table T7. Moisture and density measurements, Site U1349. (See table note.)

\begin{tabular}{|c|c|c|c|c|c|c|c|}
\hline \multirow{2}{*}{$\begin{array}{l}\text { Core, section, } \\
\text { interval }(\mathrm{cm})\end{array}$} & \multirow{2}{*}{$\begin{array}{c}\text { Top depth } \\
\text { (mbsf) }\end{array}$} & \multicolumn{3}{|c|}{ Density $\left(\mathrm{g} / \mathrm{cm}^{3}\right)$} & \multirow[b]{2}{*}{ Void ratio } & \multirow{2}{*}{$\begin{array}{c}\text { Water } \\
\text { content (\%) }\end{array}$} & \multirow{2}{*}{$\begin{array}{c}\text { Porosity } \\
\text { (\%) }\end{array}$} \\
\hline & & Bulk & Dry & Grain & & & \\
\hline \multicolumn{8}{|l|}{ 324-U1349A- } \\
\hline $5 \mathrm{R}-1,83-85$ & 145.65 & 2.061 & 1.671 & 2.698 & 0.615 & 18.916 & 38.069 \\
\hline $5 R-3,103-105$ & 148.54 & 2.246 & 1.951 & 2.738 & 0.403 & 13.098 & 28.723 \\
\hline $5 R-5,101-103$ & 151.36 & 2.340 & 2.091 & 2.762 & 0.321 & 10.633 & 24.298 \\
\hline $7 R-3,113-115$ & 168.09 & 2.593 & 2.460 & 2.827 & 0.149 & 5.117 & 12.957 \\
\hline $7 R-4,45-47$ & 168.90 & 2.586 & 2.458 & 2.809 & 0.143 & 4.944 & 12.485 \\
\hline 9R-2, 94-96 & 176.05 & 2.702 & 2.632 & 2.826 & 0.074 & 2.603 & 6.867 \\
\hline 10R-2, 15-17 & 184.86 & 2.682 & 2.630 & 2.771 & 0.053 & 1.936 & 5.071 \\
\hline 10R-3, 73-75 & 186.62 & 2.608 & 2.545 & 2.711 & 0.065 & 2.404 & 6.122 \\
\hline $10 \mathrm{R}-4,48-50$ & 187.88 & 2.636 & 2.552 & 2.780 & 0.090 & 3.197 & 8.228 \\
\hline 10R-5, 99-101 & 189.76 & 2.873 & 2.824 & 2.965 & 0.050 & 1.689 & 4.739 \\
\hline 11R-1, 36-38 & 193.26 & 2.623 & 2.520 & 2.801 & 0.111 & 3.916 & 10.030 \\
\hline 11R-2, 110-112 & 195.49 & 2.512 & 2.371 & 2.750 & 0.160 & 5.609 & 13.762 \\
\hline 11R-3, 30-32 & 196.16 & 2.577 & 2.462 & 2.775 & 0.127 & 4.479 & 11.275 \\
\hline $11 R-4,124-126$ & 198.38 & 2.546 & 2.424 & 2.751 & 0.135 & 4.779 & 11.882 \\
\hline 11R-5, 17-19 & 198.64 & 2.631 & 2.546 & 2.777 & 0.091 & 3.239 & 8.322 \\
\hline $11 \mathrm{R}-6,25-27$ & 200.16 & 2.551 & 2.422 & 2.770 & 0.144 & 5.046 & 12.570 \\
\hline $12 \mathrm{R}-2,108-110$ & 205.02 & 2.606 & 2.524 & 2.742 & 0.086 & 3.124 & 7.950 \\
\hline $12 \mathrm{R}-3,10-12$ & 205.47 & 2.713 & 2.665 & 2.797 & 0.049 & 1.778 & 4.710 \\
\hline $12 \mathrm{R}-4,40-42$ & 207.06 & 2.961 & 2.945 & 2.990 & 0.015 & 0.517 & 1.494 \\
\hline $13 \mathrm{R}-1,21-23$ & 212.31 & 2.558 & 2.444 & 2.750 & 0.125 & 4.458 & 11.136 \\
\hline 13R-3, 75-77 & 215.71 & 2.526 & 2.365 & 2.807 & 0.187 & 6.384 & 15.748 \\
\hline $13 R-5,131-133$ & 219.17 & 2.635 & 2.528 & 2.821 & 0.116 & 4.037 & 10.386 \\
\hline $14 \mathrm{R}-1,111-113$ & 222.81 & 2.485 & 2.323 & 2.759 & 0.188 & 6.522 & 15.825 \\
\hline 14R-2, 79-81 & 223.86 & 2.428 & 2.232 & 2.761 & 0.237 & 8.070 & 19.136 \\
\hline $14 R-4,93-95$ & 226.32 & 2.426 & 2.226 & 2.767 & 0.243 & 8.245 & 19.535 \\
\hline $14 R-6,81-83$ & 228.96 & 2.547 & 2.387 & 2.830 & 0.186 & 6.294 & 15.657 \\
\hline $15 \mathrm{R}-1,35-37$ & 231.65 & 2.664 & 2.571 & 2.827 & 0.100 & 3.488 & 9.072 \\
\hline $15 R-3,30-32$ & 233.86 & 2.245 & 1.943 & 2.755 & 0.418 & 13.441 & 29.468 \\
\hline 15R-5, 33-35 & 236.78 & 2.461 & 2.288 & 2.752 & 0.203 & 7.017 & 16.863 \\
\hline $16 \mathrm{R}-2,88-90$ & 243.12 & 2.158 & 1.814 & 2.730 & 0.505 & 15.915 & 33.536 \\
\hline $16 R-5,84-86$ & 247.38 & 2.741 & 2.659 & 2.890 & 0.087 & 2.989 & 8.000 \\
\hline $16 \mathrm{R}-7,56-58$ & 249.38 & 2.251 & 1.963 & 2.731 & 0.391 & 12.790 & 28.119 \\
\hline
\end{tabular}

Note: Water content is relative to wet mass. 
Table T8. Compressional wave velocity measurements, Site U1349. (See table note.)

\begin{tabular}{|c|c|c|c|c|}
\hline \multirow{2}{*}{$\begin{array}{l}\text { Core, section, } \\
\text { interval }(\mathrm{cm})\end{array}$} & \multirow{2}{*}{$\begin{array}{l}\text { Top depth } \\
\text { (mbsf) }\end{array}$} & \multicolumn{3}{|c|}{ Velocity $(\mathrm{km} / \mathrm{s})$} \\
\hline & & $x$-direction & $y$-direction & $z$-direction \\
\hline \multicolumn{5}{|l|}{ 324-U1349A- } \\
\hline 5R-1, 83-85 & 145.65 & 2.734 & 2.728 & 2.736 \\
\hline 5R-3, 103-105 & 148.54 & 3.420 & 3.397 & 3.408 \\
\hline $5 R-5,101-103$ & 151.36 & 3.756 & 3.700 & 3.816 \\
\hline $7 R-3,113-115$ & 168.09 & 4.875 & 4.872 & 4.902 \\
\hline $7 R-4,45-47$ & 168.90 & 4.813 & 4.817 & 4.851 \\
\hline $9 R-2,94-96$ & 176.05 & 5.405 & 5.545 & 5.600 \\
\hline $10 \mathrm{R}-2,15-17$ & 184.86 & 6.193 & 6.150 & 6.284 \\
\hline $10 \mathrm{R}-3,73-75$ & 186.62 & 5.892 & 5.807 & 5.897 \\
\hline $10 \mathrm{R}-4,48-50$ & 187.88 & 5.567 & 5.496 & 5.353 \\
\hline 10R-5, 99-101 & 189.76 & 4.404 & 4.392 & 4.325 \\
\hline $11 \mathrm{R}-1,36-38$ & 193.26 & 5.265 & 5.309 & 5.278 \\
\hline $11 \mathrm{R}-2,110-112$ & 195.49 & 4.546 & 4.612 & 4.641 \\
\hline $11 R-3,30-32$ & 196.16 & 4.895 & 4.928 & 4.954 \\
\hline $11 R-4,124-126$ & 198.38 & 4.654 & 4.612 & 4.796 \\
\hline 11R-5, 17-19 & 198.64 & 5.526 & 5.589 & 5.526 \\
\hline $11 \mathrm{R}-6,25-27$ & 200.16 & 4.586 & 4.684 & 4.689 \\
\hline $12 \mathrm{R}-2,108-110$ & 205.02 & 5.576 & 5.483 & 5.706 \\
\hline 12R-3, 10-12 & 205.47 & 5.936 & 6.218 & 6.171 \\
\hline $12 \mathrm{R}-4,40-42$ & 207.06 & 7.018 & 7.036 & 7.079 \\
\hline $13 R-1,21-23$ & 212.31 & 4.866 & 4.906 & 4.796 \\
\hline 13R-3, 75-77 & 215.71 & 4.459 & 4.491 & 4.512 \\
\hline $13 R-5,131-133$ & 219.17 & 4.993 & 5.196 & 5.190 \\
\hline 14R-1, 111-113 & 222.81 & 4.437 & 4.407 & 4.359 \\
\hline $14 \mathrm{R}-2,79-81$ & 223.86 & 3.991 & 3.977 & 4.003 \\
\hline $14 R-4,93-95$ & 226.33 & 4.168 & 4.182 & 4.134 \\
\hline $14 R-6,81-83$ & 228.96 & 4.451 & 4.472 & 4.514 \\
\hline $15 R-1,35-37$ & 231.65 & 5.168 & 5.198 & 5.192 \\
\hline $15 R-3,30-32$ & 233.86 & 3.308 & 3.318 & 3.347 \\
\hline $15 R-5,33-35$ & 236.78 & 4.491 & 4.531 & 4.527 \\
\hline $16 \mathrm{R}-2,88-90$ & 243.12 & 3.044 & 3.024 & 3.035 \\
\hline $16 \mathrm{R}-7,56-58$ & 249.38 & 3.327 & 3.360 & 3.394 \\
\hline
\end{tabular}

Note: Values are accurate to $\pm 20 \mathrm{~m} / \mathrm{s}$. 
Table T9. Thermal conductivity measurements, Site U1349.

\begin{tabular}{|c|c|c|c|c|}
\hline $\begin{array}{l}\text { Core, section, } \\
\text { interval }(\mathrm{cm})\end{array}$ & $\begin{array}{l}\text { Top depth } \\
\text { (mbsf) }\end{array}$ & $\begin{array}{l}\text { Thermal } \\
\text { conductivity } \\
(\mathrm{W} /[\mathrm{m} \cdot \mathrm{K}])\end{array}$ & $2 \sigma$ & Material \\
\hline \multicolumn{5}{|l|}{ 324-U1349A- } \\
\hline 5R-1, 12-24 & 144.92 & 1.572 & 0.007 & Sandstone \\
\hline $5 R-2,9-24$ & 146.36 & 1.223 & 0.008 & Sandstone \\
\hline $5 R-3,29-44$ & 147.79 & 1.013 & 0.023 & Sandstone \\
\hline $5 R-4,32-47$ & 149.19 & 1.272 & 0.022 & Sandstone \\
\hline $6 \mathrm{R}-1,7-25$ & 154.57 & 1.571 & 0.005 & Conglomerate \\
\hline $7 R-1,47-65$ & 164.57 & 1.733 & 0.011 & Igneous \\
\hline 7R-2, 0-17 & 165.47 & 1.677 & 0.018 & Igneous \\
\hline $7 R-3,111-128$ & 168.05 & 1.716 & 0.016 & Igneous \\
\hline $8 R-1,66-82$ & 169.56 & 1.997 & 0.024 & Igneous \\
\hline 9R-2, 74-93 & 175.83 & 1.720 & 0.007 & Igneous \\
\hline $9 R-3,61-74$ & 177.00 & 1.655 & 0.018 & Igneous \\
\hline 10R-1, 93-111 & 184.23 & 1.816 & 0.031 & Igneous \\
\hline 10R-2, 101-117 & 185.70 & 1.868 & 0.013 & Igneous \\
\hline 10R-5, 97-114 & 189.72 & 1.732 & 0.053 & Igneous \\
\hline 11R-1, 36-51 & 193.26 & 1.787 & 0.023 & Igneous \\
\hline $11 \mathrm{R}-3,70-83$ & 196.56 & 1.749 & 0.012 & Igneous \\
\hline $11 R-5,128-146$ & 199.75 & 1.981 & 0.040 & Igneous \\
\hline 11R-6, 0-16 & 199.92 & 1.837 & 0.032 & Igneous \\
\hline $12 \mathrm{R}-1,72-85$ & 203.22 & 2.284 & 0.047 & Igneous \\
\hline $12 R-2,53-68$ & 204.47 & 2.001 & 0.024 & Igneous \\
\hline $12 R-4,31-42$ & 206.97 & 1.933 & 0.014 & Igneous \\
\hline 13R-1, 27-43 & 212.37 & 1.509 & 0.009 & Igneous \\
\hline 13R-2, 89-101 & 214.38 & 1.978 & 0.018 & Igneous \\
\hline 13R-3, 64-79 & 215.60 & 1.803 & 0.052 & Igneous \\
\hline 13R-4, 97-110 & 217.39 & 1.654 & 0.049 & Igneous \\
\hline 13R-5, 29-41 & 218.15 & 1.621 & 0.007 & Igneous \\
\hline $13 R-6,31-42$ & 219.59 & 1.541 & 0.040 & Igneous \\
\hline $14 \mathrm{R}-1,70-83$ & 222.40 & 1.624 & 0.030 & Breccia \\
\hline $14 \mathrm{R}-3,81-95$ & 224.71 & 1.513 & 0.018 & Breccia \\
\hline $14 R-4,44-63$ & 225.84 & 1.388 & 0.011 & Breccia \\
\hline $14 R-5,0-20$ & 226.74 & 1.439 & 0.015 & Breccia \\
\hline $14 R-6,21-37$ & 228.37 & 1.481 & 0.003 & Breccia \\
\hline $15 R-2,75-88$ & 233.09 & 1.353 & 0.037 & Breccia \\
\hline $15 R-3,124-142$ & 234.80 & 1.194 & 0.009 & Breccia \\
\hline 15R-5, 0-13 & 236.46 & 1.232 & 0.025 & Breccia \\
\hline 16R-1, 57-69 & 241.47 & 1.160 & 0.032 & Breccia \\
\hline $16 \mathrm{R}-2,33-52$ & 242.57 & 1.258 & 0.017 & Breccia \\
\hline
\end{tabular}


Table T10. Demagnetization results, Site U1349. (See table notes.)

\begin{tabular}{|c|c|c|c|c|c|c|c|c|c|c|c|}
\hline \multirow{2}{*}{$\begin{array}{l}\text { Core, section, } \\
\text { interval }(\mathrm{cm})\end{array}$} & \multicolumn{2}{|c|}{ Depth (mbsf) } & \multirow[b]{2}{*}{ Demagnetization } & \multicolumn{2}{|c|}{ Fit } & \multirow[b]{2}{*}{$N$} & \multirow{2}{*}{$\begin{array}{c}\text { Inclination } \\
\left({ }^{\circ}\right)\end{array}$} & \multirow{2}{*}{$\begin{array}{l}\text { Declination } \\
\left({ }^{\circ}\right)\end{array}$} & \multirow{2}{*}{$\begin{array}{c}\text { MAD } \\
\left({ }^{\circ}\right)\end{array}$} & \multirow{2}{*}{$\begin{array}{l}\operatorname{NRM} \chi \\
(\mathrm{SI})\end{array}$} & \multirow{2}{*}{$\begin{array}{l}\text { MDF } \\
(\mathrm{mT})\end{array}$} \\
\hline & Top & Bottom & & ${ }^{\circ} \mathrm{C}$ & $\mathrm{mT}$ & & & & & & \\
\hline \multicolumn{12}{|l|}{ 324-U1349A- } \\
\hline $5 R-1,83-85$ & 145.63 & 145.65 & $\mathrm{AF}$ & & $10-60$ & 8 & 23.9 & 32.7 & 8.5 & $5.08 \mathrm{E}-03$ & 11.84 \\
\hline 5R-3, 103-105 & 148.52 & 148.54 & $\mathrm{AF}$ & & $15-60$ & 7 & 16.7 & 157.0 & 2.2 & $8.44 \mathrm{E}-03$ & 18.08 \\
\hline 5R-5, 101-103 & 151.34 & 151.36 & $\mathrm{AF}$ & & $10-80$ & 9 & 24.5 & -106.5 & 8.8 & $6.15 \mathrm{E}-03$ & 18.30 \\
\hline 7R-3, 113-115 & 168.07 & 168.09 & TH & $350-655$ & & 13 & -2.4 & 31.4 & 0.9 & $1.13 \mathrm{E}-02$ & \\
\hline $7 R-4,45-47$ & 168.88 & 168.90 & $\mathrm{AF}$ & & $7-150$ & 12 & -3.7 & 128.0 & 1.1 & $2.32 \mathrm{E}-02$ & 13.92 \\
\hline 9R-2, 94-96 & 176.03 & 176.05 & $\mathrm{TH}$ & $575-655$ & & 6 & -8.2 & 116.4 & 1.1 & $3.45 \mathrm{E}-03$ & \\
\hline 10R-2, 15-17 & 184.84 & 184.86 & $\mathrm{AF}$ & & $5-150$ & 13 & -5.8 & 4.5 & 0.9 & $2.70 \mathrm{E}-03$ & 25.98 \\
\hline $10 \mathrm{R}-3,73-75$ & 186.60 & 186.62 & TH & $350-655$ & & 13 & -7.2 & 142.7 & 3.3 & $1.42 \mathrm{E}-03$ & \\
\hline $10 R-4,48-50$ & 187.86 & 187.88 & $\mathrm{AF}$ & & $5-150$ & 13 & -8.8 & 174.7 & 0.8 & $2.98 \mathrm{E}-03$ & 32.16 \\
\hline 10R-5, 99-101 & 189.74 & 189.76 & AF & & 15-150 & 10 & -5.2 & -92.8 & 0.6 & $4.24 \mathrm{E}-03$ & 26.78 \\
\hline 11R-1, 36-38 & 193.26 & 193.28 & $\mathrm{AF}$ & & 10-150 & 12 & -8.6 & -149.4 & 1.1 & $1.67 \mathrm{E}-03$ & 33.36 \\
\hline 11R-2, 110-112 & 195.49 & 195.51 & TH & $200-640$ & & 13 & -9.3 & -176.0 & 7.6 & $4.02 \mathrm{E}-03$ & \\
\hline 11R-3, 30-32 & 196.16 & 196.18 & $\mathrm{AF}$ & & $5-150$ & 15 & -8.4 & 23.8 & 1.2 & $1.00 \mathrm{E}-02$ & 20.10 \\
\hline $11 R-4,124-126$ & 198.38 & 198.40 & $\mathrm{AF}$ & & $10-150$ & 13 & -3.8 & 146.6 & 0.6 & $3.63 \mathrm{E}-03$ & 31.77 \\
\hline 11R-5, 17-19 & 198.64 & 198.66 & $\mathrm{AF}$ & & $5-150$ & 15 & -1.0 & -35.0 & 1.0 & 1.67E-02 & 17.83 \\
\hline $11 \mathrm{R}-6,25-27$ & 200.16 & 200.18 & $\mathrm{TH}$ & $400-655$ & & 12 & -0.7 & 111.7 & 3.7 & $1.55 \mathrm{E}-02$ & \\
\hline $12 \mathrm{R}-2,108-110$ & 205.02 & 205.04 & $\mathrm{AF}$ & & $20-150$ & 12 & -6.6 & 21.3 & 1.1 & $1.59 \mathrm{E}-03$ & 71.18 \\
\hline $12 \mathrm{R}-3,10-12$ & 205.47 & 205.49 & TH & $350-655$ & & 13 & -5.1 & 129.0 & 3.0 & $2.20 \mathrm{E}-03$ & \\
\hline $12 \mathrm{R}-4,40-42$ & 207.06 & 207.08 & $\mathrm{TH}$ & $200-655$ & & 14 & 46.8 & -172.9 & 9.2 & $1.03 \mathrm{E}-02$ & \\
\hline $13 R-1,21-23$ & 212.31 & 212.33 & $\mathrm{AF}$ & & $10-120$ & 11 & -4.0 & 153.4 & 2.4 & $9.63 \mathrm{E}-04$ & 20.54 \\
\hline $13 R-3,75-77$ & 215.02 & 215.04 & $\mathrm{TH}$ & $450-640$ & & 9 & -3.6 & 19.1 & 2.4 & $4.13 \mathrm{E}-02$ & \\
\hline $13 R-5,131-133$ & 218.50 & 218.52 & $\mathrm{TH}$ & $450-640$ & & 9 & -10.3 & 61.3 & 1.6 & $1.61 \mathrm{E}-02$ & \\
\hline 14R-1, 111-113 & 222.81 & 222.83 & $\mathrm{AF}$ & & $10-100$ & 11 & -5.9 & -86.2 & 1.5 & $1.49 \mathrm{E}-03$ & 19.56 \\
\hline 14R-2, 79-81 & 223.86 & 223.88 & $\mathrm{TH}$ & $250-575$ & & 9 & -17.5 & -155.5 & 4.4 & $4.29 \mathrm{E}-03$ & \\
\hline 14R-4, 93-95 & 226.32 & 226.34 & AF & & $20-80$ & 9 & -3.9 & 109.6 & 1.1 & $2.40 \mathrm{E}-03$ & 32.30 \\
\hline $14 \mathrm{R}-6,81-83$ & 228.96 & 228.98 & TH & $150-575$ & & 10 & -35.5 & 0.7 & 2.0 & $4.08 \mathrm{E}-03$ & \\
\hline 15R-1, 35-37 & 231.65 & 231.67 & TH & $150-575$ & & 10 & 5.3 & -157.3 & 3.2 & $4.42 \mathrm{E}-03$ & \\
\hline 15R-3, 30-32 & 233.86 & 233.88 & TH & $100-400$ & & 5 & 19.3 & -5.9 & 23.0 & $4.40 \mathrm{E}-03$ & \\
\hline $15 R-5,33-35$ & 236.78 & 236.80 & $\mathrm{TH}$ & $250-575$ & & 9 & -33.1 & -63.7 & 9.8 & $1.80 \mathrm{E}-03$ & \\
\hline 16R-2, 88-90 & 243.12 & 243.14 & $\mathrm{AF}$ & & $5-35$ & 9 & 10.0 & -24.0 & 2.7 & 7.71E-04 & 17.25 \\
\hline 16R-5, 84-86 & 247.38 & 247.40 & $\mathrm{AF}$ & & $20-80$ & 8 & -13.8 & 150.7 & 2.8 & $3.31 \mathrm{E}-03$ & 21.17 \\
\hline 16R-7, 56-58 & 249.38 & 249.40 & $\mathrm{AF}$ & & $20-40$ & 5 & 42.5 & 162.9 & 1.3 & $1.10 \mathrm{E}-03$ & 19.53 \\
\hline
\end{tabular}

Notes: For all samples, principal component analysis $(\mathrm{PCA})$ is anchored to origin. $\mathrm{AF}=$ alternating field demagnetization, $\mathrm{TH}=\mathrm{thermal}$ demagnetization, $N=$ number of points used for PCA, MAD = maximum angular deviation (Kirshvink, 1980), NRM $\chi=$ bulk susceptibility of natural remanent magnetization (NRM), MDF = median destructive field.

Table T11. Logging operations, Hole U1349A. (See table notes.)

\begin{tabular}{|c|c|c|c|c|c|c|}
\hline \multirow[b]{2}{*}{ Tool string } & \multirow[b]{2}{*}{ Direction } & \multicolumn{2}{|c|}{$\begin{array}{l}\text { Interval logged } \\
\text { WMSF }(\mathrm{m})\end{array}$} & \multirow{2}{*}{$\begin{array}{l}\text { Pipe depth } \\
\operatorname{DRF}(\mathrm{m})\end{array}$} & \multirow{2}{*}{$\begin{array}{l}\text { Depth shift } \\
(\mathrm{m})\end{array}$} & \multirow{2}{*}{$\begin{array}{c}\text { Logging speed } \\
(\mathrm{m} / \mathrm{h})\end{array}$} \\
\hline & & Top & Bottom & & & \\
\hline \multirow[t]{3}{*}{ HNGS-HLDS-GPIT-DITE } & Downlog & 0 & 248 & 3256.9 & -3133 & 550 \\
\hline & Pass 1 & 103.5 & 250 & 3256.9 & -3133 & 275 \\
\hline & Pass 2 & 0 & 250 & 3256.9 & -3133 & 550 \\
\hline \multirow[t]{4}{*}{ HNGS-DSI-FMS } & Downlog & 0 & 222 & 3256.9 & -3133 & 550 \\
\hline & Uplog & & & & & \\
\hline & Pass 1 & 148 & 250 & 3256.9 & -3133 & 550 \\
\hline & Pass 2 & 0 & 250 & 3256.9 & -3133 & 550 \\
\hline
\end{tabular}

Notes: Seafloor depth $=3138$ m DRF, 3132.8 m WRF. HNGS = Hostile Environment Natural Gamma Ray Sonde, HLDS = Hostile Environment Litho-Density Sonde, GPIT = General Purpose Inclinometry Tool, DITE = Dual Induction Tool model E, DSI = Dipole Sonic Imager, FMS = Formation MicroScanner. 